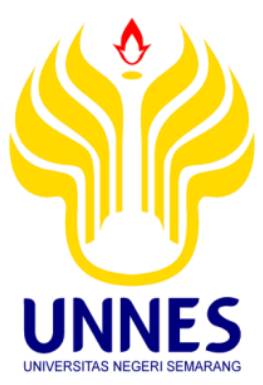

\title{
PELESTARIAN KESENIAN BABALU DI SANGGAR PUTRA BUDAYA \\ DESA PROYONANGGAN KABUPATEN BATANG
}

\section{SKRIPSI}

Untuk memperoleh gelar Sarjana Pendidikan

$\begin{array}{ll} & \text { oleh } \\ \text { Nama } & : \text { Adilah Endarini } \\ \text { NIM } & : 2501413129 \\ \text { Program Studi } & : \text { Pendidikan Seni Tari } \\ \text { Jurusan } & : \text { Pendidikan Seni Drama Tari dan Musik }\end{array}$

FAKULTAS BAHASA DAN SENI

UNIVERSITAS NEGERI SEMARANG

2017 
PERSETUJUAN PEMBIMBING

Skripsi yang berjudul "PELESTARIAN KESENIAN BABALU DI SANGGAR

PUTRA BUDAYA DESA PROYONANGGAN KABUPATEN BATANG" telah disetujui oleh pembimbing untuk diajukan ke Sidang Panitia Ujian Skripsi.

Semarang, 30 Agustus 2017

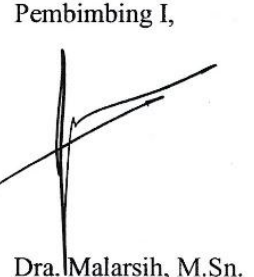

NIP. 196106171988032001
Pembimbing II

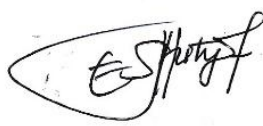

Dra. Eny Kusumastuti, M.Pd. NIP. 196804101993032001 


\section{PENGESAHAN KELULUSAN}

Skripsi ini telah dipertahankan di hadapan sidang Panitia Ujian Skripsi Jurusan Sendratasik, Fakultas Bahasa dan Seni, Universitas Negeri Semarang

$\begin{array}{ll}\text { pada hari } & : \text { Jum'at } \\ \text { tanggal } & : \text { 8 September } 2017\end{array}$

Panitian Ujian Skripsi

Dr. Sri Rejeki Urip, M.Hum (196202211989012001) Ketua

Drs. Suharto, S.Pd., M.Hum (196510181990031002)

Sekretaris

Utami Asih, S.Pd., M.A. (197001051998032001)

Penguji I
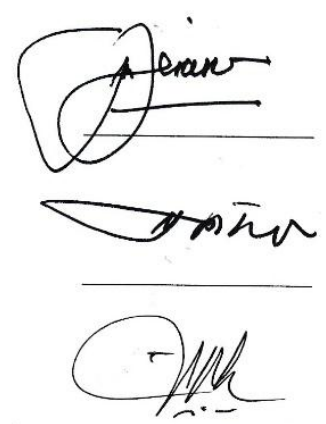

Dra. Eny Kusumastuti, M.Pd., (196804101993032001)

Penguji II/Pembimbing II

Dra. Malarsih, M.Sn., (196106171988032001)

Penguji III/Pembimbing I

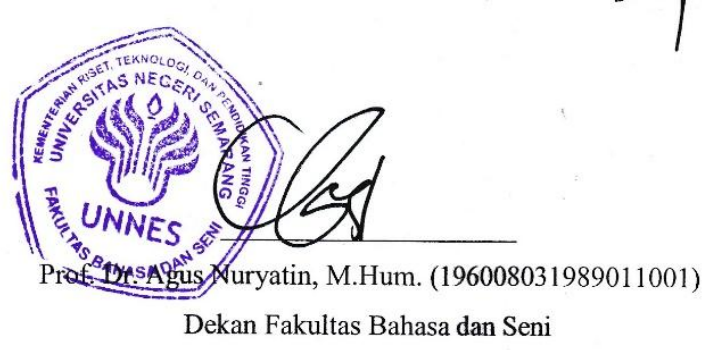

iii 


\section{PERNYATAAN}

Saya menyatakan bahwa yang tertulis di dalam skripsi ini benar-benar hasil karya saya sendiri, bukan jiplakan dari karya orang lain, baik sebagian atau seluruhnya. Pendapat atau temuan orang lain yang terdapat dalam skripsi ini dikutip atau dirujuk berdasarkan kode etik ilmiah.

Semarang, 30 Agustus 2017

Pembuat Pernyataan,

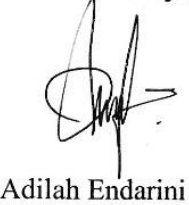

NIM 2501413129 


\section{MOTTO DAN PERSEMBAHAN}

\section{Motto:}

"Pendidikan dalam seni menjadikan hidup untuk belajar, berkreatifitas, solidaritas yang bermanfaat".

\section{Persembahan:}

Dengan rasa syukur kepada Allah SWT, skripsi ini kupersembahkan kepada :

1. Almamater tercinta, Universitas Negeri Semarang.

2. Bapak Suprayetno S.Kar., M.Si selaku pengelola Sanggar Putra Budaya yang telah mendukung dan membantu saya dalam penyelesaian skripsi ini.

3. Dra. Malarsih, M.Sn., yang telah membantu dalam pemilihan topik skripsi saya.

4. Dra. Eny Kusumastuti, M.Pd., yang telah memberi saya ilmu yang bermanfaat kepada saya. 


\section{PRAKATA}

Puji syukur penulis panjatkan kepada Tuhan Yang Maha Esa atas segala limpahan rahmat dan hidayah-Nya, sehingga penulis dapat menyelesaikan skripsi dengan judul "Pelestarian Kesenian Babalu di Sanggar Putra Budaya Desa Proyonanggan Kabupaten Batang" untuk memenuhi persyaratan guna mencapai derajat S-1 dalam bidang Pendidikan Seni Tari, Jurusan Seni Drama Tari dan Musik Fakultas Bahasa dan Seni Universitas Negeri Semarang.

Keberhasilan penulis dalam menyelesaikan skripsi tidak lepas dari bimbingan, petunjuk, bantuan, serta partisipasi dari berbagai pihak. Pada kesempatan yang baik ini, penulis ingin mengucapkan terima kasih kepada:

1. Prof. Dr. Fathur Rokhman, M.Hum., selaku Rektor Universitas Negeri Semarang yang telah memberikan kesempatan studi di Universitas Negeri Semarang.

2. Dekan Fakultas Bahasa dan Seni Universitas Negeri Semarang yang telah membantu saya dalam penyelesaian skripsi .

3. Dr. Udi Utomo, M.Si., selaku Ketua Jurusan Pendidikan Sendratasik Universitas Negeri Semarang yang telah memberi kelancaran dalam proses skripsi saya.

4. Bapak Sadarmo dan Ibu Sumaryati selaku orang tua tercinta yang selalu mendukung setiap langkah dan perjuangan saya. 
5. Bapak Suprayetno S.Kar., M.Si., selaku seniman tokoh pendiri Kesenian Babalu dan Penanggungjawab Sanggar Putra Budaya yang telah meluangkan waktu untuk membagi ilmunya kepada saya.

6. Ibu Suningsih S.Pd., M.Si., selaku seniman tari yang menjadi pelatih Kesenian Babalu di Sanggar Putra Budaya Kabupaten Batang yang selalu meluangkan waktu untuk membimbing skripsi saya.

7. Team kesenian Sanggar Putra Budaya Desa Proyonanggan Kabupaten Batang yang telah membantu memberikan data dalam penelitian.

8. Aprellian Luthfi Raharjo beserta keluarga dan Sahabat Lecit Squad yang selalu membantu dan memberi semangat dalam proses penyelesaian skripsi.

9. Teman Seni Tari 2013 (Peniti Perak).

10. Keluarga Guru SMP Negeri 1 Warungasem Batang yang selalu memberi semangat dan pengertian dalam hal waktu.

11. Semua pihak yang telah membantu dalam penyusunan skripsi ini yang tidak dapat peneliti sebutkan satu persatu.

Semoga skripsi ini dapat memberikan manfaat bagi pembaca khususnya dan bagi dunia seni pada umumnya.

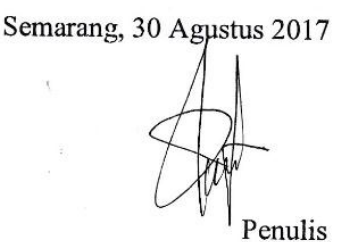




\section{SARI}

Endarini, Adilah. 2017. Pelestarian Kesenian Babalu di Sanggar Putra Budaya Desa Proyonanggan Kabupaten Batang. Skripsi. Jurusan Pendidikan Seni Drama Tari dan Musik, Fakultas Bahasa dan Seni, Universitas Negeri Semarang. Pembimbing I: Malarsih. Pembimbing II: Eny Kusumastuti.

Kata Kunci: Kesenian Babalu, Bentuk Pertunjukan, dan Pelestarian.

Kesenian Babalu merupakan kesenian yang berasal dari Kabupaten Batang dan dilestarikan di Sanggar Putra Budaya Desa Proyonanggan Kabupaten Batang. Kesenian Babalu muncul kembali ditengah masyarakat Kabupaten Batang berawal dari niat para seniman dan masyarakat di Kabupaten Batang yang ingin membangkitkan dan melestarikan kembali kesenian Babalu melalui Sanggar Putra Budaya Desa Proyonanggan Kabupaten Batang. Penelitian ini bertujuan untuk mendiskripsikan bentuk pertunjukan Kesenian Babalu serta mendiskripsikan upaya pelestarian Kesenian Babalu di Sanggar Putra Budaya Desa Proyonanggan Kabupaten Batang. Penelitian ini menggunakan metode kualitatif dengan teknik pengumpulan data menggunakan observasi, wawancara dan dokumentasi serta teknik keabsahan data diperiksa dengan metode triangulasi sumber. Teknik analisis data dalam penelitian ini menggunakan reduksi data, penyajian data, dan penarikan kesimpulan.

Hasil penelitian menunjukan bahwa bentuk pertunjukan Kesenian Babalu terdiri dari tiga tahapan, yakni awal, inti, dan akhir. Persiapan awal dalam pertunjukan Kesenian Babalu ditandai dengan bunyi peluit oleh penari Kesenian Babalu lalu penari memasuki panggung dengan ragam gerak kaki jalan ditempat. Inti pertunjukan Kesenian Babalu ditandai dengan ragam gerak diantaranya yaitu ragam gerak langkah tepuk dan ragam gerak silat. Penutup dalam pertunjukan Kesenian Babalu ditandai dengan ragam gerak jalan di tempat lalu para penari berjalan keluar panggung. Bentuk Kesenian Babalu dimunculkan melalui elemen dasar tari dan elemen pendukung tari. Elemen dasar tari terdiri dari gerak, ruang, dan waktu. Elemen pendukung tari terdiri dari musik, tata busana, tata rias, tempat pentas, waktu pelaksanaan, tata suara, properti dan penonton.

Upaya pelestarian Kesenian Babalu dilakukan melalui tiga tahap yaitu perlindungan, pemanfaatan, dan pengembangan. Upaya perlindungan kesenian Babalu dilakukan melalui pelatihan tari di Sanggar Putra Budaya, Upaya pemanfaatan dilakukan melalui pementasan-pementasan Kesenian Babalu dan upaya perkembangan dilakukan melalui perkembangan gerak, iringan dan tata busana dalam kesenian Babalu. Saran dari peneliti adalah untuk selalu memperhatikan dunia luar dengan segala modernisasi yang terjadi tetapi tidak meninggalkan tradisi Kesenian Babalu yang sesungguhnya serta selalu meningkatkan rasa cinta terhadap kesenian yang ada dengan cara saling toleransi kepada sesama untuk mempertahankan suatu kesenian agar tetap lestari dan dapat dinikmati para penerus generasi bangsa yang akan datang. 


\section{DAFTAR ISI}

\section{Halaman}

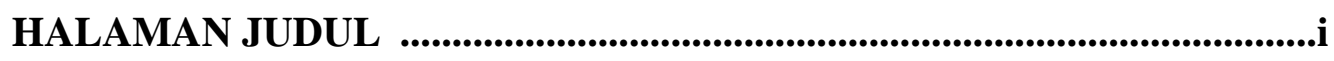
PERSETUJUAN PEMBIMBING ............................................................ii PENGESAHAN KELULUSAN ....................................................................iii

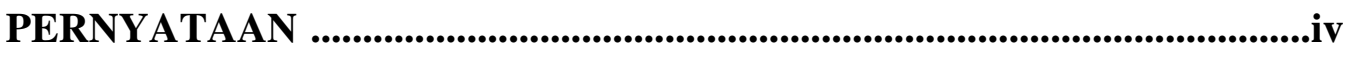
MOTTO DAN PERSEMBAHAN.............................................................

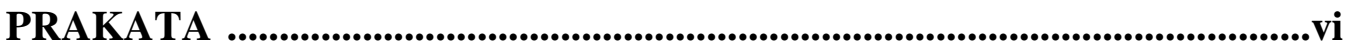

SARI

DAFTAR ISI...............................................................................................................................ix

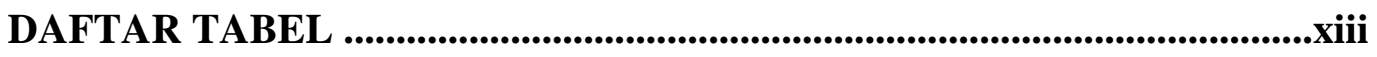

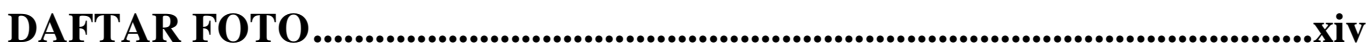

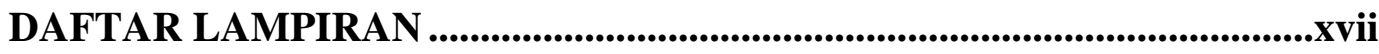

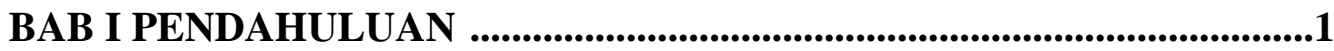

1.1 Latar Belakang Masalah .........................................................

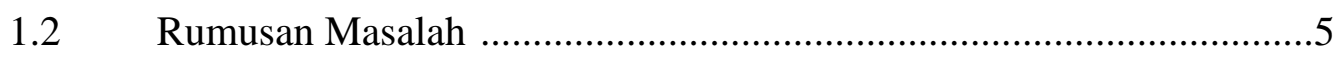

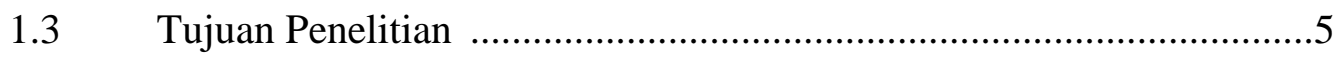

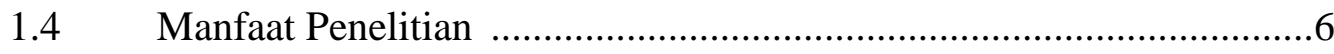

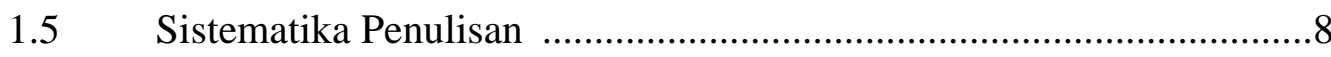

BAB II KAJIAN PUSTAKA DAN LANDASAN TEORETIS ...................9

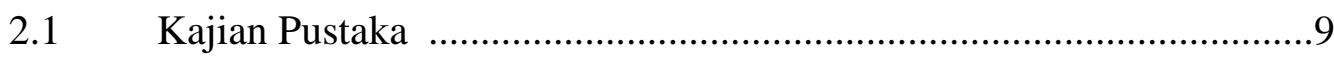




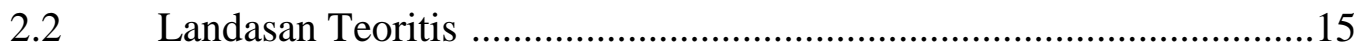

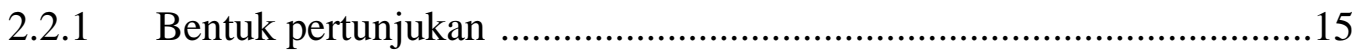

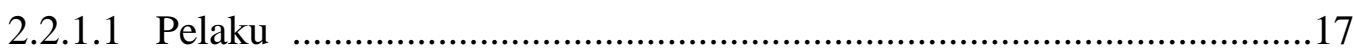

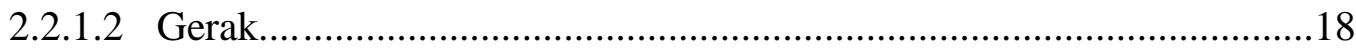

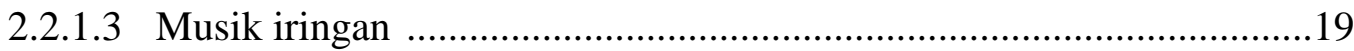

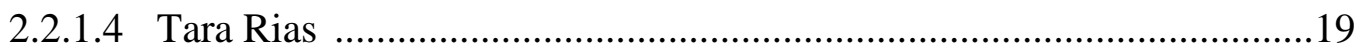

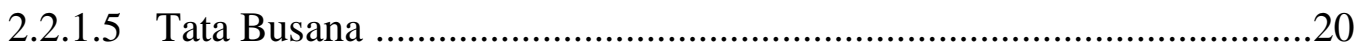

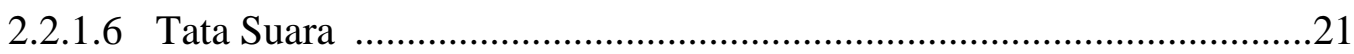

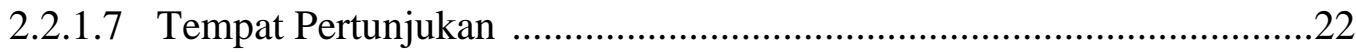

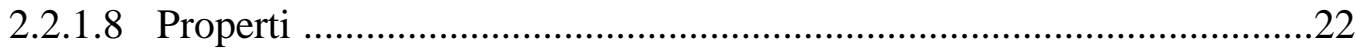

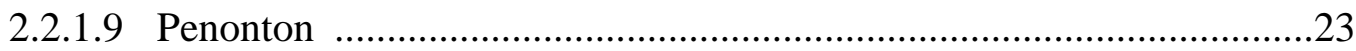

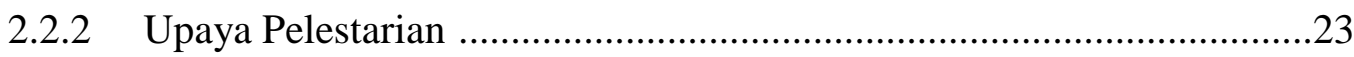

2.2.3 Kesenian Tradisional Kerakyatan ...................................................25

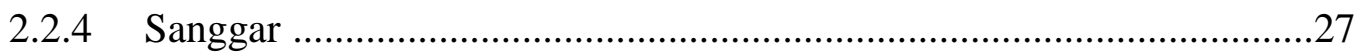

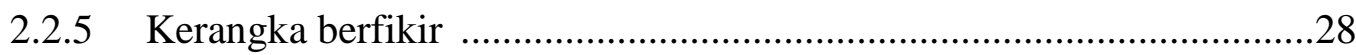

BAB III METODE PENELITIAN ............................................................30

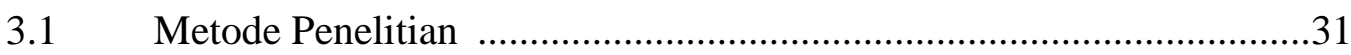

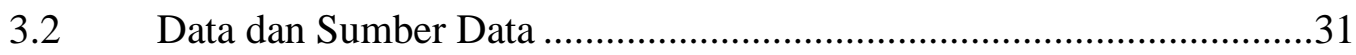

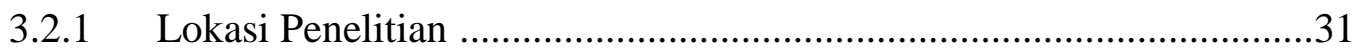

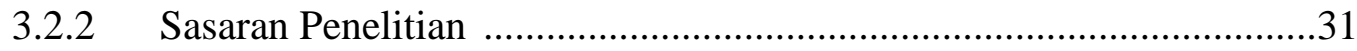

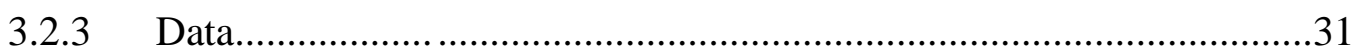

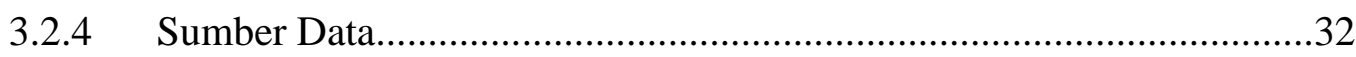

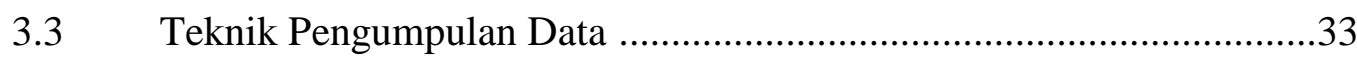




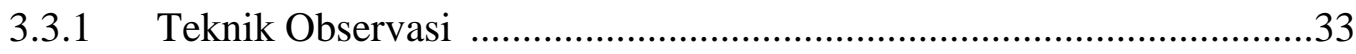

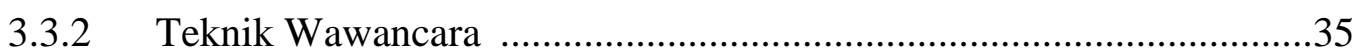

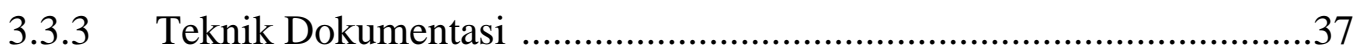

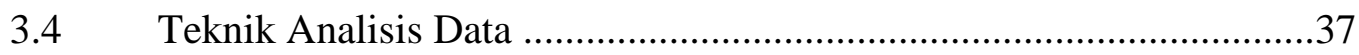

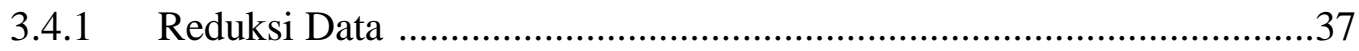

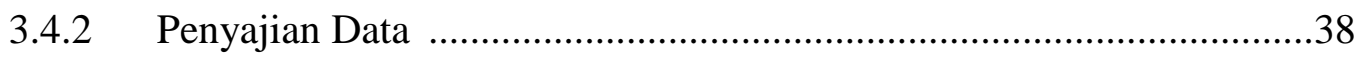

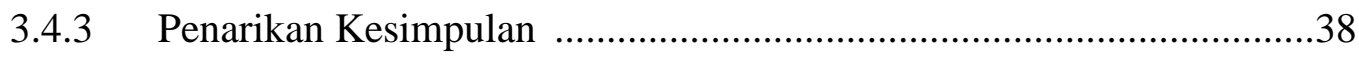

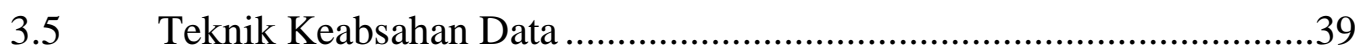

BAB IV HASIL PENELITIAN DAN PEMBAHASAN.................................42

4.1 Gambaran Umum Desa Proyonanggan .........................................42

4.1.1 Letak dan Kondisi Geografis Kabupaten Batang .............................43

4.1.2 Desa Proyonanggan Kabupaten Batang .........................................47

4.2 Data Kependudukan Desa Proyonanggan Kabupaten Batang ..............48

4.2 Sanggar Putra Budaya Desa Proyonanggan Kabupaten Batang...........53

4.2.2 Profil Sanggar Putra Budaya Desa Proyonanggan Kabupaten Batang . .54

4.2.2 Struktur Organisasi Sanggar Putra Budaya Desa Proyonanggan ..........56

4.2.3 Progam Sanggar Putra Budaya Desa Proyonanggan Kabupaten Batang .62

4.2.4 Sarana dan Prasarana Sanggar Putra Budaya Desa Proyonanggan

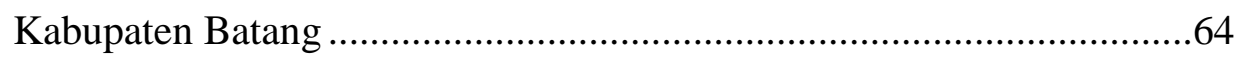

4.3 Sejarah Kesenian Babalu di Sanggar Putra Budaya Desa Proyonanggan

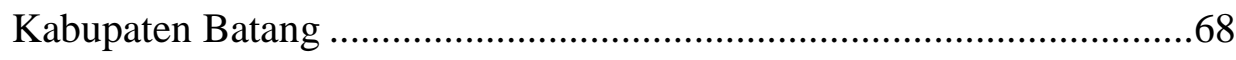


4.4 Bentuk Pertunjukan Kesenian Babalu di Sanggar Putra Budaya Desa Proyonanggan Kabupaten Batang ................................................... 71

4.4.1 Elemen Dasar dalam Kesenian Babalu ..............................................72

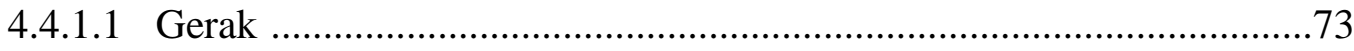

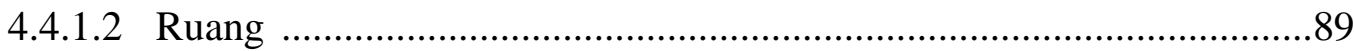

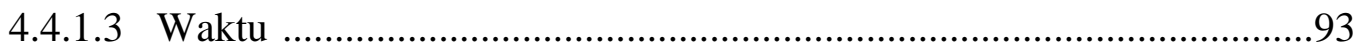

4.4.2 Elemen Pendukung Kesenian Babalu di Sanggar Putra Budaya ........94

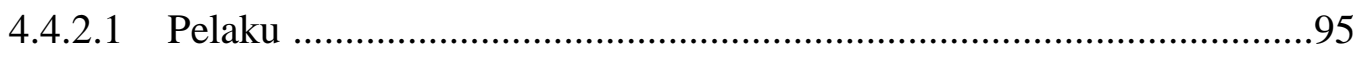

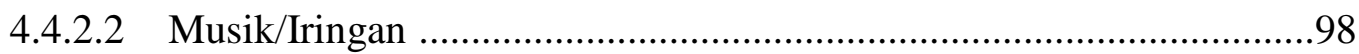

4.4.2.3 Tata Rias Kesenian Babalu di Sanggar Putra Budaya Desa Proyonanggan Kabupaten Batang .................................................................... 113

4.4.2.4 Tata Busana Kesenian Babalu .......................................................114

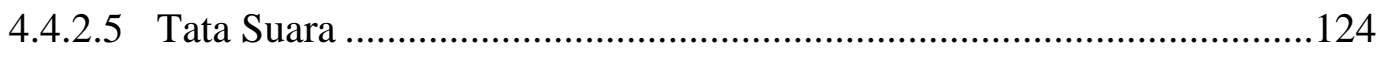

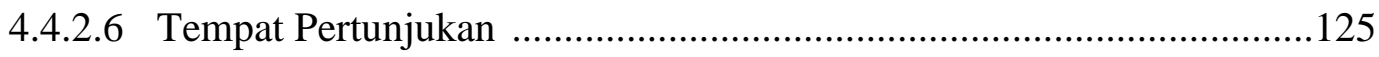

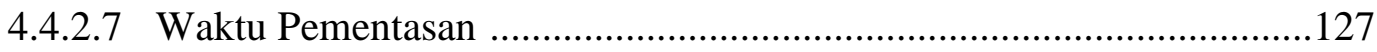

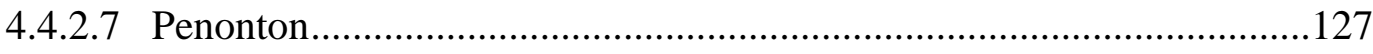

4.5 Pelestarian Kesenian Babalu di Sanggar Putra Budaya Desa Proyonanggan Kabupaten Batang ............................................... 128

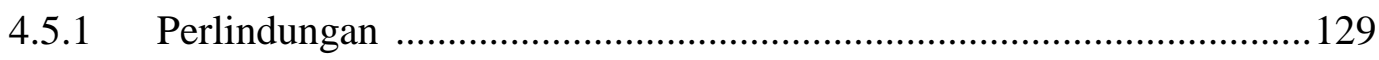

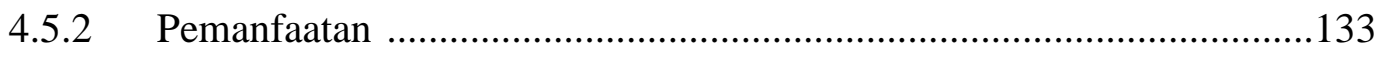

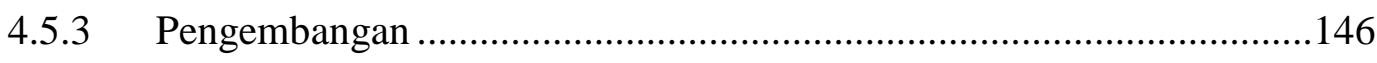

BAB V SIMPULAN DAN SARAN .............................................................155

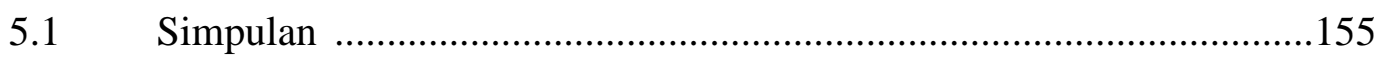




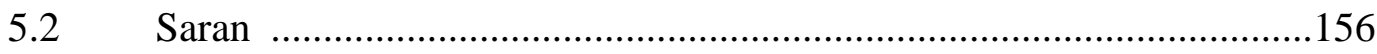

DAFTAR PUSTAKA …....................................................................................157

GLOSARIUM

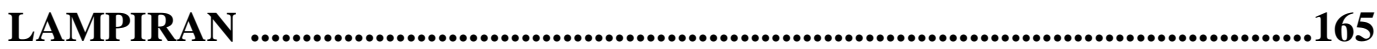

DAFTAR TABEL

Tabel

Halaman

4.1 Jumlah Penduduk Kelompok Umur Desa Proyonanggan Tengah................49

4.2 Jumlah Penduduk Desa Proyonanggan Menurut Agama.............................50

4.3 Jumlah Penduduk Menurut Pendidikan ....................................................52

4.4 Data Siswa Tari Sanggar Putra Budaya Periode 2014-2017.......................61

4.5 Data Koleksi Kostum Sanggar Putra Budaya tahun 2017 ..........................67

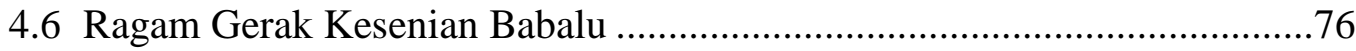

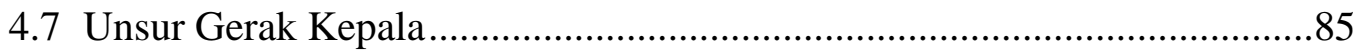

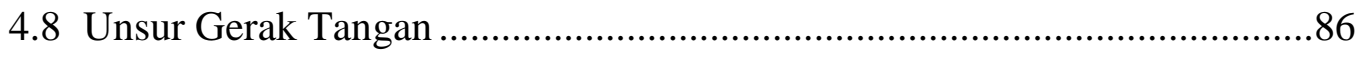

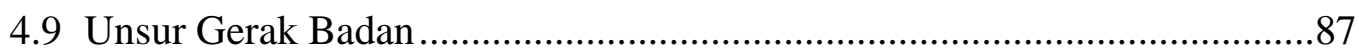

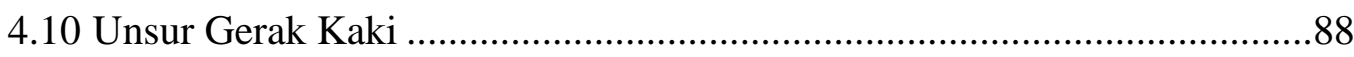




\section{DAFTAR FOTO}

Foto

Halaman

4.1 Peta Kabupaten Batang Jawa Tengah .....................................................43

4.2 Peta Lokasi Semarang ke Kabupaten Batang .......................................45

4.3 Peta Lokasi Kabupaten Batang ke Desa Proyonanggan Tengah .................46

4.4 Peta Lokasi Kantor Kelurahan Proyonanggan ..........................................54

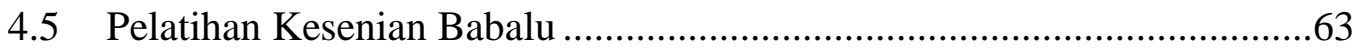

4.6 Pendopo Kelurahan Desa Proyonanggan ...............................................64

4.7 Laptop dan Speaker Sanggar Putra Budaya...........................................65

4.8 Koleksi Kostum Sanggar Putra Budaya ................................................66

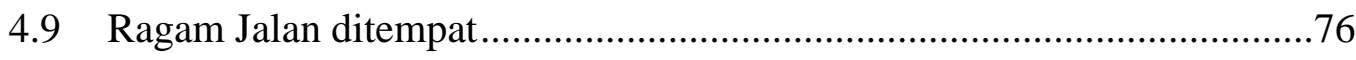

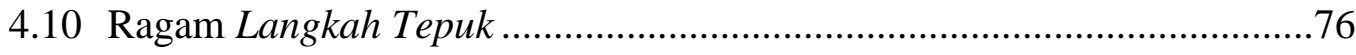

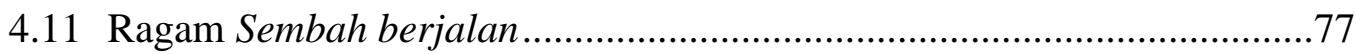

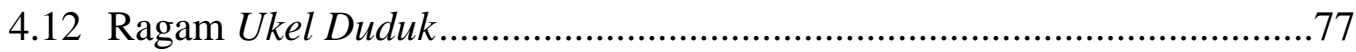

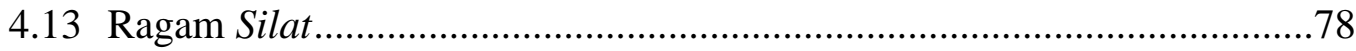

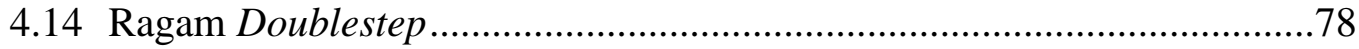

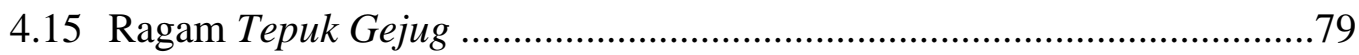

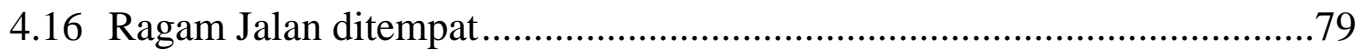

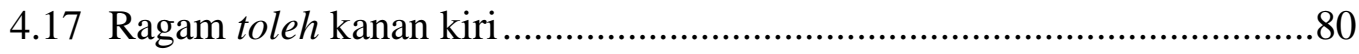

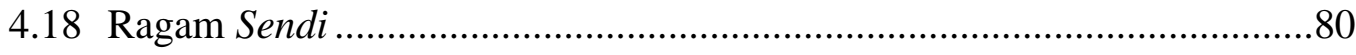

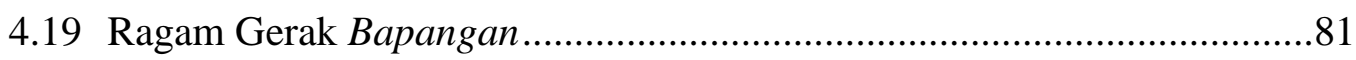

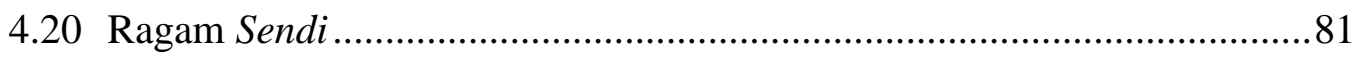

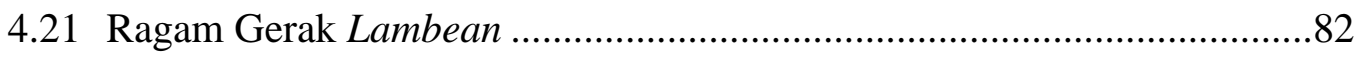




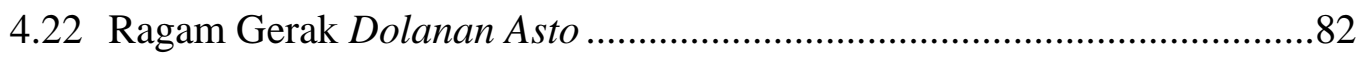

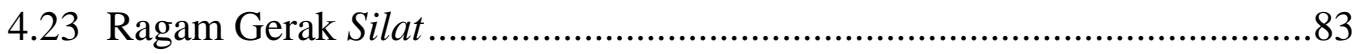

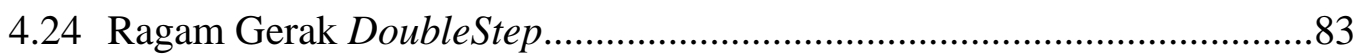

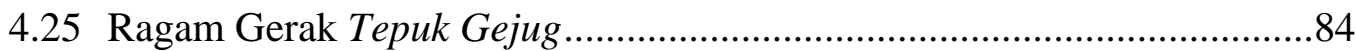

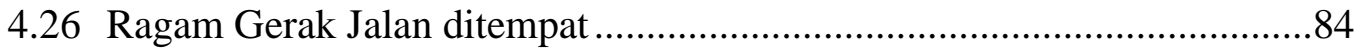

4.27 Penanggungjawab Sanggar Putra Budaya .............................................96

4.28 Pelatih Tari Sanggar Putra Budaya ......................................................97

4.29 Instrumen Musik Kesenian Babalu ........................................................99

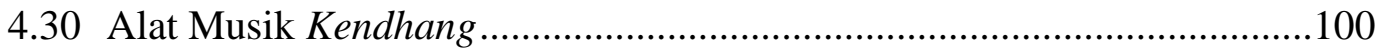

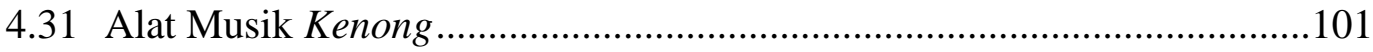

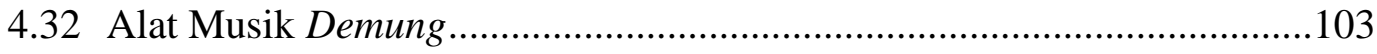

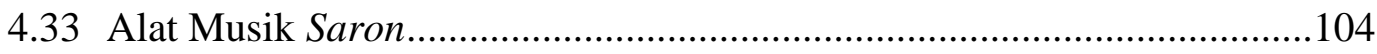

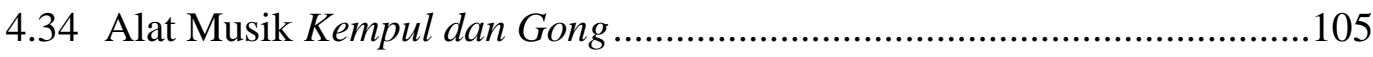

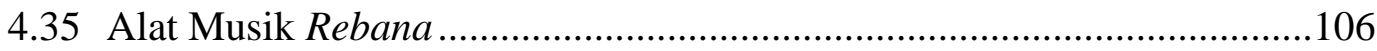

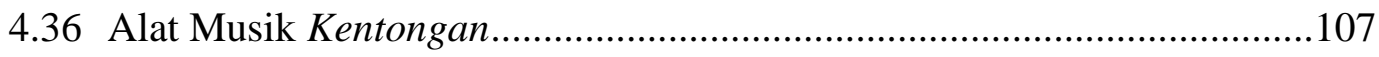

4.37 Rias wajah (Make Up) Kesenian Babalu ...............................................114

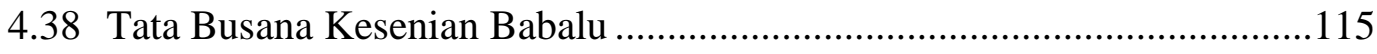

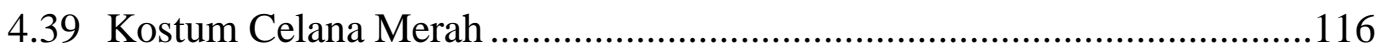

4.40 Kostum Atasan Baju Merah .................................................................117

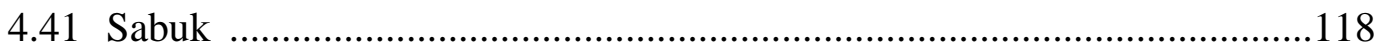

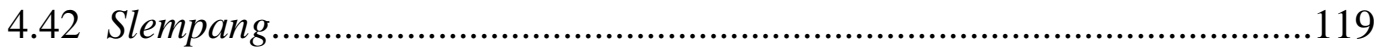

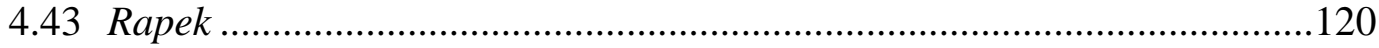

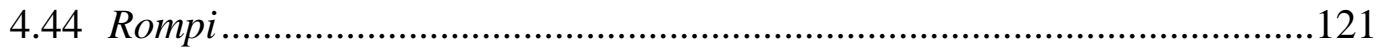

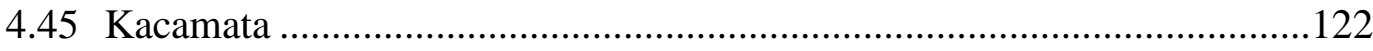

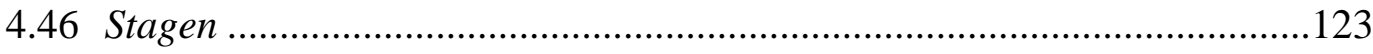


4.47 Kupluk Berkucir 124

4.48 Pendopo Kelurahan Desa Proyonanggan ................................................126

4.49 Penonton Kesenian Babalu ...................................................................... 128

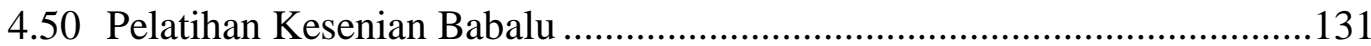

4.51 Pelatihan Kesenian Babalu oleh Mahasiswa Unnes .................................132

4.52 Pementasan Kesenian Babalu oleh Siswa SMP .....................................134

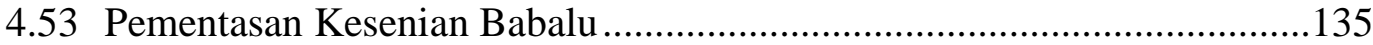

4.54 Proses Rekaman Video Kesenian Babalu Oleh Sanggar Putra Budaya ....136

4.55 Hari TNI Nasional di Alun-alun Batang..............................................137

4.56 Pameran dan Pentas Seni Tradisi di Jogja .............................................138

4.57 Festival Seni Kerakyatan di Bandung ...................................................139

4.58 Pementasan Kesenian Babalu INBOX SCTV .........................................140

4.59 Pementasan Babalu di Festival Pertunjukan Rakyat Nasional ..................141

4.60 Pementasan Kesenian Babalu BumDes ..................................................142

4.61 Mahasiswa Forkombi Usai Menarikan Kesenian Babalu.........................144

4.62 Pementasan Kesenian Babalu oleh Sanggar Puspo Budoyo .....................145

4.63 Mural Karakter Penari Kesenian Babalu ...................................................146

4.64 Perkembangan Kesenian Babalu tahun 2017 ............................................151

4.65 Piala penghargaan Pegiat Seni Tari Terbaik tahun 2017 ..........................153

4.66 Sertifikat penghargaan Pegiat Seni Tari Terbaik tahun 2017 ....................154 


\section{DAFTAR LAMPIRAN}

Foto

Halaman

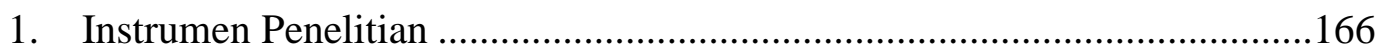

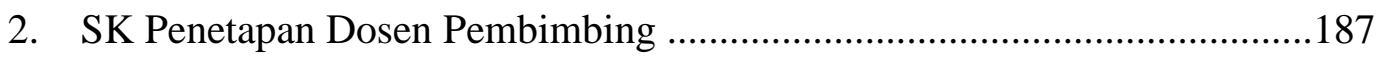

3. Surat Telah Melaksanakan Penelitian di Sanggar Putra Budaya ..................188

4. Peta Lokasi Desa Proyonanggan ..............................................................190

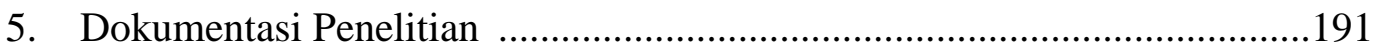




\section{BAB 1 \\ PENDAHULUAN}

\subsection{Latar Belakang Masalah}

Kesenian Babalu merupakan kesenian yang berasal dari Kabupaten Batang Jawa Tengah dan telah ada sejak zaman penjajahan yaitu sekitar tahun 1940 sebelum Negara Indonesia merdeka. Kesenian Babalu digunakan oleh masyarakat Kabupaten Batang sebagai alat untuk menyerang para penjajah tanpa harus bercucuran darah, dimana pada tahun 1940 Kesenian Babalu disajikan dalam bentuk pertunjukan seperti Teater Jawa yang didukung oleh para penari wanita yang berpakaian seperti prajurit dengan membawa peluit untuk mengelabuhi para penjajah. Selain itu Teater Jawa juga disajikan dengan cara menggunakan dialog bahasa Jawa khas Kabupaten Batang sebagai kode dalam mengatur suatu siasat perang melawan penjajah.

Kesenian Babalu asal Kabupaten Batang digunakan sebagai sarana komunikasi untuk mengumpulkan masyarakat dalam berdiskusi mencari siasat perang yang akan digunakan untuk melawan penjajah. Kode-kode tertentu dalam Kesenian Babalu mempunyai arti bahwa penjajah akan datang dari Sebelah Barat, Timur, Utara ataupun Selatan sehingga masyarakat Kabupaten Batang dapat mempersiapkan diri mencari siasat perang sebelum para penjajah datang dan memaksa masyarakat untuk kerja rodi.

Para penari wanita yang menarikan Kesenian Babalu dan para pejuang kemerdekaan mengatur suatu siasat untuk menyerang penjajah dengan cara mengelabuhi penjajah lalu memberi minuman kepada penjajah agar para penjajah 
menjadi lengah. Kode atau simbol yang telah disepakati bersama mempermudah para pejuang dalam melawan penjajah yang akan datang.

Kekompakkan masyarakat Kabupaten Batang dalam melawan penjajah melalui Kesenian Babalu akhirnya membuat para penjajah lengah, lalu masyarakat dapat melawan penjajah dengan mudah tanpa harus menggunakan senjata perang yang lengkap. Akhirnya pada tanggal 8 April 1966 tepat malam Jumat Kliwon masyarakat Kabupaten Batang ikut serta memperingati Hari Jadi Kabupaten Batang di Halaman Kanjengan Batang Lama atau di rumah Dinas Bupati Batang. (Wawancara : Suprayetno 12 Februari 2017)

Kesenian Babalu merupakan kesenian yang tumbuh dan berkembang di Sanggar Putra Budaya Desa Proyonanggan yang berasal dari Kabupaten Batang. Kesenian Babalu di Kabupaten Batang mempunyai arti kata yang berasal dari kata Baba yaitu suatu aba-aba dan kata $L u$ adalah pada jaman dahulu. Jadi arti kata Kesenian Babalu adalah suatu kesenian yang telah ada sejak jaman dahulu berisi tentang suatu aba-aba atau siasat dalam melawan penjajah. Kesenian Babalu tergolong kedalam kesenian kerakyatan yang dalam pertunjukannya ditampilkan secara beramai-ramai. Kesenian Babalu di Kabupaten Batang selalu menjadi tontonan yang sangat digemari oleh masyarakat, dimana setiap adanya pertunjukan Kesenian Babalu banyak sekali masyarakat yang datang untuk menonton Kesenian Babalu. Namun seiring berjalannya waktu keberadaan Kesenian Babalu tidak berlangsung lama dan mengalami kevakuman pada tahun 1970-1990 dilihat dari jarang ditemui adanya pertunjukan Kesenian Babalu dan minat masyarakat dalam menikmati pertunjukan Kesenian Babalu yang mulai menurun. 
Pada tahun 2000, Sanggar Putra Budaya dan para pecinta seni di Kabupaten Batang menghidupkan kembali Kesenian Babalu dan mengemas Kesenian Babalu menjadi lebih menarik baik dari segi gerak maupun dari segi iringannya serta sesuai perkembangan zaman tanpa menghilangkan ciri khas dan makna yang terdapat dalam Kesenian Babalu, seperti dalam penelitian Febriana Budi Palupi dengan judul “Bentuk Pertunjukan dan Makna Simbolis Kesenian Babalu di Kabupaten Batang" yang didalamnya membahas salah satunya tentang makna simbolis dalam segi gerak, musik dan tata busana serta menyimbolkan keprajuritan dalam mengatur siasat perang untuk melawan penjajah dengan menggunakan peluit sebagai suatu kode.

Sanggar Putra Budaya merupakan sanggar yang berada di Desa Proyonanggan Kabupaten Batang yang berdiri sejak tahun 1985 oleh tokoh seniman Batang yaitu Bapak Sukimto. Sanggar Putra Budaya merupakan sanggar yang melatihkan Kesenian Babalu kepada masyarakat Kabupaten Batang. Keberadaan Sanggar Putra Budaya sangat membantu terhadap perkembangan kesenian yang berada di Kabupaten Batang dan sekitarnya karena Sanggar Putra Budaya melestarikan kesenian tradisional dengan pelatihan tari secara rutin diantaranya yaitu tari tradisional anak serta tari kreasi seperti Tari Kukilo, Tari Merak, Tari Molek dan Tari Kelinci.

Sanggar Putra Budaya di Desa Proyonanggan Kabupaten Batang mengemas Kesenian Babalu menjadi kesenian pertunjukan rakyat yang bertujuan selain sebagai media hiburan tetapi juga digunakan sebagai media komunikasi untuk menumbuhkan rasa nasionalisme dan membangun semangat perjuangan. Kesenian 
Babalu tergolong kesenian tradisional kerakyatan yang sering dipentaskan untuk memperingati acara-acara penting salah satunya seperti memperingati HUT Kemerdekaan RI, Hari Jadi Kabupaten Batang, Khitanan, Kliwonan, Hajatan dan acara-acara penyambutan.

Keberadaan Kesenian Babalu kian waktu mulai mengalami penurunan dalam pertunjukannya di Kabupaten Batang, Hal ini dikarenakan oleh beberapa faktor yaitu munculnya kesenian-kesenian kreasi baru, jarang ditemui adanya pertunjukan Kesenian Babalu secara rutin di Kabupaten Batang dan menurunnya minat masyarakat dalam melestarikan Kesenian Babalu. Namun melalui Sanggar Putra Budaya di Desa Proyonanggan Kabupaten Batang Kesenian Babalu tetap berusaha untuk dilestarikan dan dikembangkan agar tetap tumbuh seiring berkembangnya waktu.

Sanggar Putra Budaya di Desa Proyonanggan Kecamatan Batang berusaha mengadakan pelatihan Kesenian Babalu kepada masyarakat Kabupaten Batang. Para pecinta seni di Kabupaten Batang juga ikut termotivasi untuk melestarikan Kesenian Babalu dengan mempelajari Kesenian Babalu secara rutin. Mempelajari Kesenian Babalu secara rutin akan sangat bermanfaat sebagai sarana komunikasi dalam menjalin silaturahmi serta untuk melestarikan kesenian tradisi khas Kabupaten Batang.

Berawal dari semangat dan dorongan niat salah satu tokoh seniman di Kabupaten Batang yaitu Bapak Suprayetno yang ingin menghidupkan kembali Kesenian Babalu melalui Sanggar Putra Budaya Desa Proyonanggan Kabupaten Batang, maka peneliti tertarik untuk mengkaji bagaimana usaha yang dilakukan 
untuk melestarikan Kesenian Babalu di Kabupaten Batang dengan mengangkat judul "Pelestarian Kesenian Babalu di Sanggar Putra Budaya Desa Proyonanggan Kabupaten Batang”.

\subsection{Rumusan Masalah}

Bedasarkan latar belakang masalah yang peneliti paparkan diatas, maka permasalahan pokok yang akan dikaji adalah :

1. Bagaimana Bentuk Pertunjukan Kesenian Babalu di Sanggar Putra Budaya Desa Proyonanggan Kabupaten Batang?

2. Bagaimana Upaya Pelestarian Kesenian Babalu di Sanggar Putra Budaya Desa Proyonanggan Kabupaten Batang?

\subsection{Tujuan Penelitian}

Bedasarkan permasalahan yang dikemukakan di atas, tujuan yang hendak dicapai dalam penelitian ini adalah :

1 Mengetahui dan mendeskripsikan Bentuk Pertunjukan Kesenian Babalu di Sanggar Putra Budaya Desa Proyonanggan Kabupaten Batang.

2. Mengetahui dan mendeskripsikan Upaya Pelestarian Kesenian Babalu di Sanggar Putra Budaya Desa Proyonanggan Kabupaten Batang.

\subsection{Manfaat Penelitian}

Kajian terhadap Pelestarian Kesenian Babalu di Sanggar Putra Budaya Desa Proyonanggan Kabupaten Batang diharapkan dapat memberikan manfaat baik secara langsung maupun tidak langsung bagi semua pihak yang terkait. Manfaat 
penelitian Pelestarian Kesenian Babalu dapat dibagi menjadi 2 (dua) yaitu manfaat secara teoritis dan manfaat secara praktis.

\subsubsection{Manfaat Teoritis}

Hasil penelitian tentang Pelestarian Kesenian Babalu di Sanggar Putra Budaya Desa Proyonanggan Kabupaten Batang diharapkan dapat memberikan informasi tentang Bentuk Pertunjukan Kesenian Babalu dan Upaya Pelestarian Kesenian Babalu bagi masyarakat secara umum serta bermanfaat sebagai bahan referensi bagi pembaca khususnya mahasiswa Pendidikan Sendratasik Fakultas Bahasa dan Seni Universitas Negeri Semarang.

\subsubsection{Manfaat Praktis}

\section{Bagi Pencipta}

Penelitian ini diharapkan dapat bermanfaat dalam menambah semangat berkarya dan merangsang kreativitas pencipta (pelaku seni) agar semakin kreatif untuk menciptakan ide-ide baru dalam kegiatan berkesenian khususnya terhadap Pelestarian Kesenian Babalu di Sanggar Putra Budaya Desa Proyonanggan Kabupaten Batang.

2. Bagi Penari

Penelitian ini bermanfaat bagi para pecinta tari dalam memberi motivasi kepada penari untuk senantiasa melestarikan kesenian tradisional salah satunya yaitu Kesenian Babalu yang tumbuh dan berkembang di Sanggar Putra Budaya Desa Proyonanggan Kabupaten Batang.

3. Bagi Pemilik Sanggar Putra Budaya Desa Proyonanggan Kabupaten Batang 
Hasil penelitian ini diharapkan dapat digunakan sebagai acuan oleh pemilik Sanggar Putra Budaya sebagai informasi bagi masyarakat umum mengenai Bentuk Pertunjukan dan Upaya Pelestarian Kesenian Babalu di Sanggar Putra Budaya Desa Proyonanggan Kabupaten Batang.

4. Bagi Masyarakat di Kabupaten Batang

Hasil penelitian ini diharapkan dapat bermanfaat menambah wawasan untuk masyarakat Batang, khususnya generasi muda agar mengenal dan melestarikan kesenian daerahnya, terutama mengenai Pelestarian Kesenian Babalu di Sanggar Putra Budaya Desa Proyonanggan Kabupaten Batang.

\subsection{Sistematika Penulisan}

Sistematika penulisan berisi gambaran mengenai keseluruhan isi skripsi, yang disusun sebagai berikut:

Sebelum masuk pada bagian isi, terlebih dahulu memaparkan Judul Skripsi, Persetujuan Pembimbing, Pengesahan Kelulusan, Pernyataan, Motto dan Persembahan, Prakata, Sari, Daftar Isi, Daftar Tabel, Daftar Foto dan Daftar Lampiran.

Bagian isi terdiri dari lima bab dengan rincian setiap bab adalah sebagai berikut:

Bab I : Pendahuluan

Dalam bab I diuraikan Latar Belakang Masalah, Rumusan Masalah, Tujuan Penelitian, Manfaat Penelitian, dan Sistematika Penulisan Skripsi. Bab II : Kajian Pustaka dan Landasan Teoritis 
Memuat Kajian Pustaka dan Landasan Teoritis yang berhubungan dengan rumusan masalah yang dibahas dalam penelitian ini, yang meliputi: Kesenian, Bentuk Kesenian, Elemen Dasar Tari, Pelestarian, dan Kerangka Berfikir.

Bab III : Metode Penelitian

Membahas tentang Metode Penelitian yang meliputi: Metode Penelitian, Pendekatan Penelitian, Data dan Sumber Data, Teknik Pengumpulan Data, Teknik Keabsahan Data, dan Teknik Analisis Data.

Bab IV : Hasil dan Pembahasan

Pada bab IV memuat data-data yang diperoleh sebagai hasil penelitian dan dibahas secara deskriptif kualitatif. Data yang diperoleh meliputi hal yang berkaitan tentang : Kesenian Babalu di Kabupaten Batang, Sanggar Putra Budaya di Desa Proyonanggan Kabupaten Batang, Bentuk Pertunjukan Kesenian Babalu dan Pelestarian Kesenian Babalu di Sanggar Putra Budaya Desa Proyonanggan Kabupaten Batang.

Bab V : Penutup

Bab V : Merupakan bab terkhir yang memuat Simpulan dan Saran 


\section{BAB 2}

\section{KAJIAN PUSTAKA DAN LANDASAN TEORITIS}

\subsection{Kajian Pustaka}

Rencana penenelitian ini tidak lepas dari penelitian-penelitian sebelumnya, seperti hasil penelitian berikut ini :

Pertama, Penelitian Febriana Budhi Palupi (2011) yang berjudul "Bentuk Pertunjukan Dan Makna Simbolis Kesenian Babalu Di Kabupaten Batang”. Hasil penelitian tersebut membahas mengenai bentuk pertunjukan dan makna simbolis Kesenian Babalu yang berupa deskripsi pertunjukan tari Babalu dari awal pementasan sampai akhir pementasan serta aspek-aspek pertunjukan meliputi gerak tari, deskripsi gerak tari, dan unsur gerak yang meliputi unsur gerak kepala, tangan, badan dan kaki serta gerak tari Babalu dalam prespektif tenaga, ruang dan waktu. Tata busana dalam tari Babalu meliputi pakaian kupluk berkuncir, kaca mata, slempang, baju lengan panjang, sabuk, rapek, celana tiga perempat dan kaos kaki. Tata rias tari Babalu dideskripsikan meliputi bentuk alis, eyeshadow, pemerah pipi / blash on, dan lipstick. Makna simbolis Kesenian tari Babalu di Kabupaten Batang yaitu gerak, musik dan tata busana yang menyimbolkan keprajuritan dalam mengatur siasat perang untuk melawan penjajah dengan menggunakan kode yaitu peluit. Dari segi fungsi, tari Babalu berfungsi sebagai sarana hiburan dan sering ditampilkan diacara-acara penyambutan serta tanggapan. Penelitian Febriana Budhi Palupi (2011) mempunyai persamaan yaitu sama-sama mengkaji tentang Kesenian Babalu namun Perbedaan dalam penelitian yang akan dilakukan yaitu mengkaji dan

membahas lebih dalam tentang Pelestarian Kesenian Babalu yang berada di 
Sanggar Putra Budaya Desa Proyonanggan Kabupaten Batang, meskipun begitu hal tersebut sangat bermanfaat untuk melengkapi kajian Bentuk pertunjukan dan Pelestarian Kesenian Babalu yang akan dilakukan.

Kedua, Penelitian Dyah Sri Rahayu (2013) yang berjudul “Kajian Bentuk dan Fungsi Pertunjukan Kesenian Lengger Budi Lestari Kecamatan Kledung Kabupaten Temanggung" yang membahas bentuk kesenian tradisional Lengger yang hidup dan berkembang di desa Tuksari Kecamatan Kledung Kabupaten Temanggung yang terdiri dari unsur yaitu gerak, tata rias dan busana, lalu musik iringan yang digunakan adalah gamelan dengan laras slendro serta meliputi empat jenis musik iringan yaitu untuk tari halus, tari gagah, tari kasar dan untuk tari gecul, kemudian tembang atau lagu, meliputi dua macam yaitu tembang-tembang yang mempunyai maksud-maksud tertentu dan jenis tembang yang hanya digunakan untuk menghidupkan suasana pentas yang biasanya berwujud parikan. Parikan adalah salah satu bagian dalam kesenian tradisional ludruk yang berisi pesan atau pantun dengan cerita kocak. Pementasan Lengger juga membutuhkan perlengkapan yang harus ada yaitu : (a) topeng, (b) sesaji, (c) tata lampu dan (d) tata suara. Fungsi Kesenian Lengger yaitu untuk keperluan upacara ritual antara lain upacara potong rambut gombak, khitanan, perkawinan, bersih desa, sadranan sungai dan sebagainya, juga berfungsi untuk hiburan dan memperingati hari-hari besar nasional seperti HUT Proklamasi Kemerdekaan Republik Indonesia, Hari Sumpah Pemuda, dan kegiatan apresiasi seni. Penelitian Dyah Sri Rahayu (2013) membahas tentang bentuk pertunjukan dan Fungsi Kesenian Lengger. Persamaan dalam penelitian yang akan dilakukan yaitu terdapat pada bentuk pertunjukan, dan 
perbedaanya yaitu belum banyak mengupas tentang upaya pelestariannya. Namun hal tersebut bermanfaat untuk melengkapi kajian Bentuk pertunjukan dan Pelestarian Kesenian Babalu yang akan dilakukan.

Ketiga, Penelitian Sri Handayani (2015) yang berjudul "Upaya Pelestarian Eksistensi Kesenian Barongan Setyo Budoyo di Desa Loram Wetan Kecamatan Jati Kabupaten Kudus”. Hasil penelitian tersebut membahas mengenai bentuk penyajian dan fungsi kesenian Barongan Setyo Budoyo serta Upaya Pelestarian Eksistensi Kesenian Barongan Setyo Budoyo di desa Loram Wetan Kecamatan Jati kabupaten Kudus yang berupa deskripsi bentuk penyajian kesenian Barongan yang terdiri dari gerak, alur pementasan, tema, tata busana, tata rias, panggung, tata suara, dan tata lampunya. Bentuk penyajian kesenian Barongan Kudus adalah drama tari dengan isi ceritanya tentang kisah penyebaran Agama Islam yang dipadukan dengan legenda Singo Barong dan kerajaan Majapahit. Alur pementasan kesenian Barongan Kudus terdiri atas tiga babak, yang masing-masing babak terdiri atas beberapa adegan. Babak yang pertama adalah sajian tari bersama yang dilakukan oleh tokoh Penthul, Singo Barong, dan kelompok tari Jaran Kepang yang dipimpin oleh Penthul. Babak kedua berupa sajian cerita kesenian Barongan Kudus yang berupa drama atau menyerupai kethoprak. Babak ketiga berupa sajian atraksi magis (jaran dor). Selain itu juga membahas mengenai upaya pelestarian dan pemberdayaan kesenian Barongan dengan mengemas kesenian Barongan Setyo Budoyo menjadi sebuah suguhan kesenian yang memikat, namun efisien waktu dalam pementasannya lalu mendatangkan bintang tamu dalam pementasan seni pertunjukan kesenian Barongan Setyo Budoyo agar lebih berdaya jual dan menarik 
pengunjung. Kemudian juga menerapkan manajemen profesional dalam pementasan seni pertunjukan kesenian Barongan Setyo Budoyo dan melakukan langkah-langkah sistematis dan terprogram dalam melakukan proses pewarisan nilai-nilai adiluhung serta kerja sama secara sinergis antara Dinas Pariwisata dengan Komunitas seni pertunjukan dan institusi terkait guna membumikan kesenian tradisi sebagai upaya pelestarian dan pewarisan seni budaya tradisi. Penelitian Sri Handayani (2015) sangat bermanfaat sebagai referensi serta untuk melengkapi kajian pelestarian kesenian Babalu yang akan dilakukan.

Penelitian Nainul Khutniah (2013) tentang "Upaya mempertahankan Eksistensi Tari Krida Jati di Sanggar Hayu Budaya Kelurahan Pengkol Kecamatan Jepara Kabupaten Jepara”. Hasil penelitian tersebut membahas mengenai upaya mempertahankan eksistensi Tari Kridha Jati di Sanggar Hayu Budaya Kelurahan Pengkol Kecamatan Pengkol Kabupaten Jepara yang dapat ditarik kesimpulan sebagai berikut, Eksistensi pertunjukan Tari Kridha Jati di sanggar Hayu Budaya kelurahan Pengkol kecamatan Pengkol kabupaten Jepara bisa dikatakan "eksis". Terkait dengan Upaya Mempertahankan Eksistensi Tari Kridha Jati, upaya yang dilakukan oleh sanggar Hayu Budaya dengan pihak-pihak terkait yaitu tari Kridha Jati dijadikan materi tetap bahan ajar di sanggar Hayu Budaya, pementasan yang mempertahankan kualitas yang dilakukan dengan berusaha menampilkan Tari Kridha Jati ketika ada permintaan penawaran pementasan. PEMDA dan Dinas Pariwisata berupaya mempertahankan eksistensi dengan menampilkan Tari Kridha Jati dalam acara-acara PEMDA dan Dinas Pariwisata, pementasan pada upacara-upacara penting atau penyambutan tamu, 
melakukan kaderisasi dan penobatan tari Kridha Jati sebagai tarian khas kota Jepara. Penelitian Nainul Khutniah (2013) mempunyai persamaan yaitu dalam membahas upaya mempertahankan kesenian dan mempunyai perbedaan dalam objek yang akan diteliti, namun penelitian Nainul Khutniah sangat bermanfaat untuk mengupas penelitian tentang upaya pelestarian yang akan dilakukan.

Penelitian Widuandi Gupita (2012) di Jurnal Seni tari yang berjudul “Bentuk Pertunjukan Kesenian Jamilin di Desa Jatimulya Kecamatan Surodadi Kabupaten Tegal”. Hasil Penelitian tersebut membahas mengenai bentuk pertunjukan kesenian Jamilin di Desa Jatimulya Kecamatan Suradadi Kabupaten Tegal meliputi pelaku, gerak, iringan, tata rias dan tata busana, tata pentas, tata suara, tata lampu dan properti. Pertunjukan kesenian Jamilin dapat diartikan berupa gerak-gerak seni beladiri pencak silat yang dimainkan oleh sekelompok putri yang diiringi alat musik terbang genjring, gitar, kethuk, gong, demung dan bedug dengan lagu-lagu yang bernafaskan ajaran agama Islam dan terdapat orgen tunggal lagu tegalan, lawak, permainan akrobat dan sulap sebagai bonus dari pertunjukan. Perpaduan antara gerak dan musik pertunjukan kesenian Jamilin dirangkum dalam pasal. Pasal merupakan bagian gerakan dalam pencak silat. Urutan penyajian kesenian Jamilin dimulai dari orgen tunggal lagu Tegalan untuk menarik perhatian dan mengajak orang-orang berkumpul agar dapat menyaksikan pertunjukan inti dari kesenian Jamilin, kemudian tari Jamilin, lawak, permainan akrobat dan sulap. Penelitian Widuandi Gupita (2012) mempunyai persamaan yaitu mengkaji tentang bentuk pertunjukan kesenian dan perbedaanya yaitu belum mengupas secara mendalam tentang upaya pelestarian kesenian namun sangat 
bermanfaat dalam melengkapi kajian bentuk pertunjukan dan upaya pelestarian yang akan dilakukan.

Penelitian lain yakni penelitian yang dilansir dalam artikel Eny Kusumastuti dan Hartono pada tahun 2017 dengan judul Kuda Debog Dance for Childrens Social Development memuat tentang bentuk pertunjukan tarian Kuda Debog dan perkembangan sosial anak dalam tari Kuda Debog. Penelitian ini menggunakan metode kualitatif dengan observasi, wawancara, dan dokumentasi sebagai metode pengumpulan data. Validitas data di diverifikasi dengan menggunakan triangulasi. Metode analisis data adalah analisis domain, taksonomi, dan componential serta penciptaan tema untuk menggambarkan makna fokus penelitian. Hasil penelitian menunjukkan bentuk pertunjukan, termasuk cerita, pelaku, gerakan, suara, make up properti, pola lantai, panggung pertunjukan, dan penonton. Perkembangan sosial anak terjadi dalam persiapan pertunjukan serta selama pertunjukan kepada masyarakat dan tamu pertunjukan. Hal itu juga terjadi pada penutupan pertunjukan.

Penelitian Eny Kusumastuti dan Hartono terletak pada kajian bentuk pertunjukan. Perbedaan yang terdapat dalam penelitian Eny Kusumastuti dan Hartono dengan penelitian ini terletak pada objek tari yakni Tari Kuda Debog sedangkan Objek peneliti yaitu tentang Kesenian Babalu namun hal ini sangat bermanfaat dalam melengkapi kajian bentuk pertunjukan dan upaya pelestarian yang akan peneliti lakukan.

Keenam Hasil penelitian yang pernah dilakukan jelas berbeda dengan penelitian yang akan dilakukan oleh peneliti akan tetapi sangat bermanfaat untuk studi awal dalam membantu memberikan konsep-konsep yang bisa diperlukan 
karena pencapaian yang ditargetkan dalam penelitian ini adalah Pelestarian Kesenian Babalu di Sanggar Putra Budaya Desa Proyonanggan Kabupaten Batang, yang akan dianalisis dari Bentuk Pertunjukan dan Upaya Pelestarian Kesenian Babalu di Sanggar Putra Budaya Desa Proyonanggan Kabupaten Batang.

\subsection{Landasan Teoritis}

Landasan teoretis merupakan seperangkat landasan atau dasar yang berisi konsep, definisi, dan proporsisi yang digunakan oleh penulis dalam melakukan sebuah penelitian. Landasan teoritis dalam penelitian ini meliputi teori bentuk pertunjukan yang terdiri dari elemen dasar tari serta elemen pendukung tari, dan pelestarian.

\subsubsection{Bentuk Pertunjukan}

Jazuli (2001:5) mengatakan bahwa bentuk adalah suatu struktur yang menunjuk pada sistem atau pengucapan, yang didalamnya terkandung faktor-faktor yang kait-mengkait dan saling bergantung satu dengan yang lainnya dalam mewujudkan satu kesatuan yang utuh. Tarian kelompok berkaitan struktur yang muncul bukanlah sekedar penari yang satu dengan penari yang lainnya mampu mengkoordinasikan gerak sesuai dengan tempat yang telah ditetapkan, melainkan juga harus mengikatkan dengan unsur keruangannya.

Bentuk pertunjukan tari merupakan keseluruhan suatu penyajian tari yang berfungsi untuk mengungkapkan ekspresi jiwa manusia yang di komunikasikan lewat gerak antara seniman dengan penghayat seni. Suatu sajian tari akan memiliki nilai estetis apabila didalamnya terdapat elemen-elemen penyajian tari secara terpadu. Adapun bentuk tari terlihat dari keseluruhan penyajian tari, yang 
mencakup paduan antara elemen tari (gerak, ruang, waktu) maupun berbagai unsur pendukung penyajian tari (iringan, tema, tata busana, rias, tempat, dan tata cahaya) (Jazuli 2008: 8).

Soedarsono (2001:1) mengatakan bahwa Seni Pertunjukan sebagai disiplin yang masih muda, seperti halnya ilmu-ilmu humaniora yang lain yang juga belum tua, selalu mengalami nasib yang sama dalam menggunakan pendekatan dan metode penelitiannya. Seni pertunjukan dalam kehidupan manusia sudah sangat tua usianya dan memiliki fungsi yang bermacam-macam. Pengertian bentuk pertunjukan adalah sebuah kajian tentang bagian-bagian dari suatu pertunjukan tari. Bentuk penyajian adalah suatu wujud fisik yang menunjukan sesuatu pertunjukan dalam hal ini tari, yang telah tersusun secara berurutan demi memberikan hasil yang memuaskan bagi penikmat atau penonton.

Analisis bentuk atau struktur tari mempunyai kajian utamanya yaitu terdapat pada bagian-bagian dan tata hubungan antar bagian tari. Dalam konteks bentuk pertunjukan tari maka dapat diberi pengertian bahwa kajian bentuk pertunjukan tari adalah kajian tentang tata hubungan antar elemen pertunjukan tari. Dalam bentuk pertunjukan tari, bagian-bagian pertunjukan menyangkut pola penyajian pertunjukan dan komponen pertunjukan.

Tari adalah suatu bentuk pernyataan imajinatif yang tertuang melalui medium kesatuan simbol-simbol gerak, ruang, dan waktu (Jazuli 2016: 34). Berbicara bentuk tidak terlepas dari keberadaan struktur atau aspek (bahan/material baku dan aspek pendukung lainnya) sehingga mewujudkan suatu bentuk (Jazuli 2008: 7). Bentuk tari terlihat dari keseluruhan penyajian tari, yang mencakup 
paduan antara elemen tari (gerak, ruang, waktu) maupun berbagai unsur pendukung penyajian tari (iringan, tema, tata busana, rias, tempat, dan tata cahaya) (Jazuli 2008: 8).

Jazuli (1994: 9-26) berpendapat bahwa suatu pertunjukan tidak hanya menampilkan serangkaian gerak yang tertata baik, rapi dan indah, tetapi juga harus dilengkapi dengan berbagai tata rupa atau unsur-unsur lain yang dapat mendukung penampilannya, dengan demikian pertunjukan akan mempunyai daya tarik dan pesona untuk membahagiakan penonton yang menikmatinya. Teori yang dikemukakan oleh Jazuli (2008: 8) dapat dirumuskan bahwa bentuk tari dapat dilihat dari elemen dasar tari dan elemen pendukung tari. Elemen dasar tari mengandung elemen gerak, ruang, dan waktu. Elemen pendukung tari terdiri dari iringan, tema, tata busana, rias, tempat, dan tata cahaya. Jazuli (2016: 60) melengkapi teorinya dengan menambah properti sebagai elemen pendukung tari.

\subsubsection{Pelaku}

Pelaku adalah suatu aspek terpenting dalam sebuah pertunjukan seni, tanpa adanya pelaku sebuah totonan seni tidak akan berjalan. Pertama-tama muncul dari wajah penonton adalah sosok atau figur penarinya, menampakan gerakan yang lemah gemuali didukung oleh tata busana, polesan wajah dan tubuh penari. Dalam sebuah pertunjukan seni dimana pelaku seni mempunyai aspek daya tarik tersendiri. Hal ini secara langsung atau tidak langsung sangat mungkin menimbulkan kesan yang mampu merangsang libido penonton (Jazuli, 2001: 7).

Semua bentuk pertunjukan tentunya memerlukan penyaji sebagai pelaku atau seniman yang terlibat langsung maupun tidak langsung untuk 
mengetengahkan atau menyajikan bentuk seni pertunjukan. Seorang penari harus menyadari bahwa tubuh sangat penting karena bagi penari tubuh merupakan sarana komunikasi terhadap penonton ketika sedang membawakan peranannya. Bentuk tubuh yang khas sering menghadirkan tehnik-tehnik gerak yang khas pula. Postur tubuh yang tinggi besar akan mempunyai tehnik gerak yang berbeda dengan postur tubuh yang kecil, ketika melakukan sebuah tarian yang sama (Jazuli, 1994:6)

\subsubsection{Gerak}

Gerak adalah suatu unsur pokok dalam sajian tari karena peranan gerak sangat mendominasi dalam sebuah tari. Berdasarkan penyampaian wujud dan maksud yang diketengahkan gerak dapat dibedakan menjadi empat kategori. Pertama adalah gerak yang diutarakan melalui simbol-simbol maknawi disebut Gesture. Kedua gerak murni yang lebih mengutamakan kaindahan dan tidak menyampaikan pesan maknawi. Ketiga gerak penguat ekspresi yang dinamakan baton signal. Keempat adalah gerak pindah tempat (Kusmayati, 2000:77).

Gerak harus ada kekuatan yang mampu mengubah suatu sikap dari anggota tubuh. Gerak dalam seni tari merupakan perpaduan serangkaian jenis gerak anggota tubuh yang dapat di nikmati dalam satuan waktu dan ruang tertentu, artinya gejala yang menimbulkan gerak adalah tenaga dalam dan yang bergerak artinya memerlukan ruang dan membutuhkan waktu ketika proses gerak berlangsung.

Tari adalah perpaduan gerak ritmis yang indah dari seluruh atau sebagian badan baik spontan maupun gerakan terlatih yang telah disusun dengan seksama disertai ekspresi atau ide tertentu yang selaras dengan musik, sehingga memberi 
kesenangan kepada pelaku atau penghayatnya. Keindahan dalam tari hadir demi suatu kepuasan, kebahagiaan dan harapan batin manusia, baik pencipta, peraga maupun penikmatnya (Jazuli,1994:13).

\subsubsection{Musik/Iringan}

Musik adalah suatu patner dalam tari yang tidak boleh ditinggalkan, karena musik adalah patner tari, maka musik yang akan dipergunakan untuk mengiring sebuah tarian harus betul-betul digarap sesuai dengan garapan tarinya (Soedarsono 1981: 46-47).

Menurut Jazuli (1994: 9-12) musik atau suara dalam tari pada dasarkan dibedakan menjadi dua bentuk yaitu bentuk internal dan bentuk eksternal. Bentuk internal adalah iringan tari yang berasal dari dalam diri penari itu sendiri seperti teriakan, tarikan nafas, dan hentakan kaki. Bentuk eksternal adalah iringan tari yang berasal dari luar diri penari. Iringan ini dapat berupa suatu nyanyian, instrumen gamelan, orkestra musik dan sebagainya.

\subsubsection{Tata Rias}

Tata rias adalah tampilan pertama yang akan dilihat oleh penonton sebelum pertunjukan dimulai dengan mengubah karakter pribadi menjadi karakter tokoh yang diperlukan, untuk memperkuat ekspresi dan menambah daya tarik penari pada penampilannya (Jazuli 1994 : 18).

Komponen penunjang wujud busana rias dan properti adalah kehadiran warna. Warna turut mengambil bagian dalam beberapa benda yang disertakan dalam sebuah pertunjukan serta didalam tatarias dan busana yang dikenakan (Kusmayati, 2000: 91) 
Tata rias tari tetap konsisten terhadap kaidah-kaidah yang diperlukan dalam pertunjukan tari, maka perlu diperhatikan prinsip-prinsip penataan rias tari antara lain (1) Rias hendaknya mencerminkan karakter tokoh/peran, (2) Kerapian dan kebersihan rias perlu diperhatikan, (3) Garis-garis yang dikehendaki jelas, (4) Ketepatan pemakaian desain rias (Jazuli, 1994 : 20).

Rias panggung (Stage make up) adalah rias yang diciptakan untuk penampilan di atas panggung yang berbeda dengan rias sehari-hari. Tata rias panggung dibedakan menjadi dua, yaitu tata rias panggung (tertutup) dan tata rias panggung arena (terbuka). Tata rias panggung (tertutup) dianjurkan agar riasan lebih tegas, jelas garis-garisnya dan tebal, karena penonton melihat pertunjukan dalam jarak yang cukup jauh. Tata rias panggung arena (terbuka), pemakaian rias tidak perlu terlalu tebal, yang lebih utama adalah halus dan rapi karena penonton berada lebih dekat dengan pertunjukan (Jazuli, $1994: 20)$.

\subsubsection{Tata Busana}

Busana tari adalah alat yang dipakai untuk menutupi bagian-bagian tubuh sesuai dengan norma masyarakat yang berlaku serta berfungsi untuk mendukung tema atau isi tari dan untuk memperjelas peranan dalam suatu sajian tari (Jazuli, 1994:17).

Busana dalam penyajian seni pertunjukan akan menjadi daya tarik yang terlihat lebih awal dan menjadi perhatian langsung oleh penonton. Penataan busana yang bagus akan menambah daya tarik dan dapat mempesona para penonton yang menyaksikannya. Busana atau pakaian bukan hanya ditempatkan sebagai penutup 
tubuh, tetapi darinya terungkap kedalaman makna yang melalui simbol-simbol yang mengandung beragam aspek keindahan (Kusmayati, 2000:96).

\subsubsection{Tata Suara}

Tata suara adalah jembatan komunikasi antara pertunjukan dengan penonton, artinya penonton dapat mendengar dengan baik dan jelas iringan dan isi yang mau dipertunjukan. Dalam tata suara yang perlu diperhatikan adalah pembagian yang benar distribusi suara (spoot anjerphone) yang ada. Penataan suara yang kurang baik dapat menghancurkan keseluruhan pertunjukan karena mengakibatkan hubungan antar elemen tidak terkoordinasi secara baik (Jazuli 2001 : 120).

Suara berasal dari dua sumber bunyi berbeda yang mempunyai kedudukan yang bermacam-macam. Suara dapat menjadi mitra, menata ritme, atau bahkan memperkuat gerak yang akan ditampilkan. Suara dalam seni pertunjukan dibedakan menjadi dua yaitu suara yang berasal dari para peserta dan suara yang bersumber dari instrumen musik tertentu (Kusmayati, 2000:86).

Tata suara (sound system) merupakan sarana penyambung dari suara yang berfungsi sebagai pengeras suara baik dari vocal atau iringan alat musik. Sebuah pertunjukan memiliki kualitas suara yang baik, tergantung dari penataan Sound system yang mempertimbangkan besar kecilnya tempat pertunjukan. Penataan suara dapat dikatakan berhasil bila dapat menjadi jembatan komunikasi antara pertunjukan dengan penontonnya, artinya penonton dapat mendengar dengan baik dan jelas tanpa gangguan apapun sehingga penonton dapat menikmatinya dengan nyaman (Jazuli, 1994: 25). 


\subsubsection{Tempat Pertunjukan}

Suatu pertunjukan apapun bentuknya selalu memerlukan tempat atau iringan guna menyelenggarakan pertunjukan itu sendiri. Tempat pentas dalam tari terdiri dari dua yaitu panggung terbuka dan panggung tertutup. Di Indonesia kita dapat mengenal bentuk-bentuk tempat pertunjukan atau pentas seperti di lapangan terbuka atau arena terbuka, di pendopo atau di pemanggungan/staging (Jazuli, 1994: 20).

\subsubsection{Properti}

Properti adalah unsur pendukung yang memperkuat isi dan penyampaian pesan serta kesan kepada penonton kesenian. Properti yang juga berperan serta berfungsi sebagai sesaji bukan hanya benda-benda atau barang-barang yang dipersembahkan yang sesudahnya dapat disantap bersama komunitas sebuah peristiwa pertunjukan (Kusmayati, 2000:96).

Properti berfungsi sebagai elemen tari untuk menghidupkan tarian dan memberikan kesan yang mendalam bagi penonton. Properti dalam tari bisa dikatakan merupakan perlengkapan yang seolah-olah menyatu dengan badan penari, maka desain atasnya harus betul-betul diperhatikan agar properti tari secara teatrikal dapat menguntungkan dan ukurannya dapat sesuai dengan membuat ukuran properti lebih besar dari ukuran sesungguhnya.

\subsubsection{Penonton}

Penonton adalah seseorang yang menonton suatu pertunjukan yang menentukan berhasil tidaknya sebuah pertunjukan (Palupi, 2011:36). Oleh karena itu penonton harus diperhitungkan dalam perencanaan penyajian suatu seni 
pendukungnya juga bagaimana tingkat apresiasi masyarakat pada keberadaan seni pertunjukan tersebut.

Masyarakat merasa tertarik pada kesenian pertunjukan tersebut maka kesenian tersebut akan tumbuh terus meskipun mengalami perubahan atau penyempurnaan, dengan maksud yaitu seni akan dapat menghayati selama berlangsungnya proses ungkap oleh pelakunya dan seni disajikan untuk dinikmati dan ditonton oleh khalayak atau penonton. Jadi bentuk seni mendapatkan perhatian dari orang yang menyaksikan (Bastomi, 1992:42).

\subsubsection{Upaya Pelestarian}

Strategi pelestarian warisan budaya berkenaan dengan dua aspek, yaitu (1) kelembagaan dan (2) sumber daya manusia. Disamping itu harus pula ditetapkan lebih dahulu, apa tujuan dari pelestarian warisan budaya itu. Pelestarian mempunyai makna bahwa didalamnya terdapat dua aspek yaitu pemertahanan dan dinamika (Sedyawati, 2008: 208).

Pelestarian budaya yang dirumuskan dalam draf RUU tentang Kebudayaan (1999) dijelaskan bahwa pelestarian budaya berarti pelestarian terhadap eksistensi suatu kebudayaan dan bukan berarti membekukan kebudayaan didalam bentuk-bentuknya yang sudah pernah dikenal saja. Pelestarian dilihat sebagai sesuatu yang terdiri dari tiga aspek, yaitu (1) perlindungan, (2) pengembangan, dan (3) pemanfaatan (Sedyawati, 2008: 152)

Berdasarkan beberapa pengertian yang ada dapat diartikan bahwa upaya mempertahankan atau pelestarian merupakan suatu proses, teknik atau cara untuk 
mempertahankan atau menjaga keaslian sesuatu supaya tetap utuh dan menjadi lebih baik dengan mengembangkan perwujudan yang bersifat selektif sesuai dengan situasi dan kondisi yang selalu berubah dan berkembang. Pelestarian juga dapat diartikan suatu proses atau teknik yang didasarkan pada kebutuhan individu itu sendiri. Kelestarian tidak dapat berdiri sendiri. Oleh karena itu harus dikembangkan pula. Melestarikan suatu kebudayaan pun dengan cara mendalami atau paling tidak mengetahui tentang budaya itu sendiri. Mempertahankan nilai budaya, salah satunya dengan mengembangkan seni.

Pelestarian menurut Sedyawati (2008 : 209) adalah sesuatu yang harus dijaga agar keseimbangan senantiasa dipertahankan antara keberlanjutan dan perubahan, sedemikian rupa agar jati diri bangsa atau suku bangsa senantiasa tampil dengan jelas dan tidak ditenggelamkan oleh pengaruh-pengaruh asing tertentu. Salah satu kiat untuk sambil berubah mempertahankan jati diri adalah dengan memilih diantara sejumlah warisan budaya yang merupakan penanda budaya untuk dijaga dan dikembangkan dengan lebih intensif daripada warisan-warisan budaya yang lain.

Pelestarian menurut Sedyawati (2008 : 280) adalah suatu budaya yang apabila dianggap masih berguna karena relevansinya dengan kehidupan, maka tentulah memerlukan upaya-upaya pelestarian yang berkelanjutan, adapun tindakan-tindakan pelestarian yang dapat ditempuh adalah :

1. Pendokumentasian secermat mungkin dengan menggunakan berbagai media yang sesuai, hasil dokumentasi dapat menjadi sumber acuan apabila 
disimpan di tempat yang aman dan diregistrasi secara sistematis dengan kemungkinan penelusuran yang mudah.

2. Pembahasan dalam rangka penyadaran, khususnya mengenai nilai-nilai budaya, norma dan estetika.

3. Pengadaan acara penampilan yang memungkinkan orang mengamati dan menghayati.

Tanpa ketiga tindakan-tindakan suatu pelestarian mungkin tidak akan terjadi dengan sendirinya secara alamiah. Tantangan suatu kebudayaan dari luar dapat merupakan tandingan yang dapat "mengalahkan" lebih-lebih yang "daya pancarnya" lebih kuat.

\subsubsection{Kesenian Tradisional Kerakyatan}

Kesenian merupakan sesuatu yang lazim dijadikan objek daya tarik karena memiliki ciri khas yang menandai sesuatu masyarakat etnik tertentu yang disajikan dalam konteks asli dalam keunggulan berupa keautentikannya (Sedyawati, 2008:154-155). Hal ini disebabkan karena kesenian tradisional bersumber dan berakar pada kebiasaan pendukungnya serta menjadi salah satu ciri khas suatu wilayah. Kesenian lahir dari konsep seseorang namun tidak dapat dipastikan siapa penciptanya, kesenian ini timbul di tengah kelompok masyarakat pendukungnya. Seni tradisional terkandung corak dan budaya yang mencerminkan pribadi masyarakatnya.

Menurut Sedyawati (2008: 240) tradisi merupakan segala produk yang "tradisional" selalu berkembang menurut fitrahnya sendiri, dan mempunyai hak 
hidupnya yang otonom. Tradisipun tidaklah selalu harus dilihat sebagai sesuatu yang statis, karena didalamnya selalu ada unsur kreativitas, dalam modus dan takaran yang beragam.

Kesenian tradisional di Indonesia dibagi menjadi dua yaitu kesenian tradisional klasik dan tradisional kerakyatan. Kesenian tradisional klasik adalah kesenian yang berkembang dipusat pemerintahan atau kerajaan, sedangkan kesenian tradisional kerakyatan adalah kesenian yang berkembang secara beragam di desa dan kalangan rakyat jelata (Tim Abdi Guru 2002:107). Ciri kesenian tradisional klasik menurut Soedarsono (1978:13) sebagai berikut: Semula berkembang dikalangan raja dan bangsawan. Telah mencapai kristalisasi artistik yang tinggi. Telah menempuh jalan sejarah yang cukup panjang sehingga memiliki nilai tradisional. Jazuli (1994: 64) mengemukakan ciri kesenian tradisional kerakyatan yaitu bentuknya yang sederhana, penampilannya ekspresif, spontan dan umumnya berfungsi ritual dan tidak terikat pada ketentuan-ketentuan yang baku. Kesenian Babalu merupakan Kesenian Tradisi Kerakyatan dikarenakan bentuknya sederhana, ekspresif dan tidak terlalu baku.

\subsubsection{Sanggar}

Khutniah dalam Poerwadarminto (1984: 569) mengatakan bahwa sanggar adalah tempat pertemuan yang dihadiri oleh sekelompok manusia atau orang yang biasa diadakan secara teratur dan berkala untuk suatu penelitian, diskusi, atau kegiatan pembahasan mengenai bidang tertentu. Sanggar merupakan pendidikan luar sekolah, yaitu pendidikan yang diterima dalam keluarga, dalam lembaga yang 
tidak berupa sekolah ataupun dalam masyarakat (Khutniah dalam koentjaraningrat, 1984: 38).

Wahyuningsih dalam Hartono (1984: 132) mengatakan bahwa sanggar tari merupakan sarana melakukan aktivitas berkesenitarian oleh sekelompok orang yang meliputi pelestarian, penelitian, dan kerjasama. Sanggar tari sangat diperlukan kehadirannya oleh masyarakat, seniman, dan pemerintah sebagai sarana untuk menumbuh kembangkan kesenian tari di Indonesia. Sanggar tari diharapkan sebagai tempat dalam upaya menjaga dan melestarikan kesenian tari baik seni tari tradisi maupun seni tari moderen, sebagai tempat pelatihan yang di dalamnya akan terjadi proses belajar mengajar serta tempat beberapa seniman bekerja sama sehingga menghasilkan suatu kreativitas pada seni khususnya tari, dan sebagai tempat penelitian dan apresiasi.

Sanggar merupakan wadah kegiatan dalam membantu menunjang keberhasilan penguasaan keterampilan (Rusliana, 1994: 13). Menurut Sutopo dalam Hartono (2000: 45-46) komponen yang dapat menunjang kehidupan seni meliputi seniman sebagai karya, karya seni yang merupakan bentuk nyata dari suatu karya seni yang dapat dihayati, dinikmati dan ditangkap dengan panca indera dan penghayat yaitu masyarakat konsumen tari. Ketiga komponen tersebut harus ada. Bila tidak ada maka syarat untuk kehidupan berkesenian akan gagal.

Sifat sanggar tari merupakan suatu organisasi yang dikelola secara professional pada bidang tertentu atau mengkhususkan pada suatu bidang tari. Bagi anggota sanggar yang telah menyelesaikan masa keanggotaannya akan mendapatkan bukti diri sebagai anggota sanggar berupa sertifikat ataupun rapot. 
Disamping itu sanggar tari diharapkan dapat berfungsi untuk mengembangkan sekaligus melestarikan seni tari sebagai wadah dalam kehidupan dan bisa meningkatkan keterampilan serta kemampuan anak didik di sanggar (Jazuli, 1994:57)

\subsubsection{Kerangka Berfikir}

Pada penelitian peneliti akan mendeskripsikan dan menjelaskan bagaimana Upaya Pelestarian Kesenian Babalu, sebelum itu peneliti menganalisis bentuk pertunjukan yang terdapat di dalam Kesenian Babalu terlebih dahulu, yaitu meliputi unsur-unsur pendukung dalam tari yaitu pelaku, gerak, musik/iringan, tata rias, tata busana, tata suara, tempat pertunjukan, properti dan penonton. Setelah itu peneliti membahas tentang upaya pelestarian Kesenian Babalu yang di bagi menjadi tiga pembahasan yaitu upaya perlindungan yang dilakukan dengan mengadakan pelatihan-pelatihan, upaya pemanfaatan Kesenian Babalu dengan mengadakan pementasan-pementasan Kesenian Babalu dan upaya pengembangan dengan membatasi perkembangan gerak, iringan dan busananya. Hal tersebut di lakukan agar diperoleh hasil penelitian tentang Pelestarian Kesenian Babalu di Sanggar Putra Budaya Desa Proyonanggan sebagai berikut : 
Penelitian ini menggunakan kerangka berfikir seperti pada bagan 2.1.

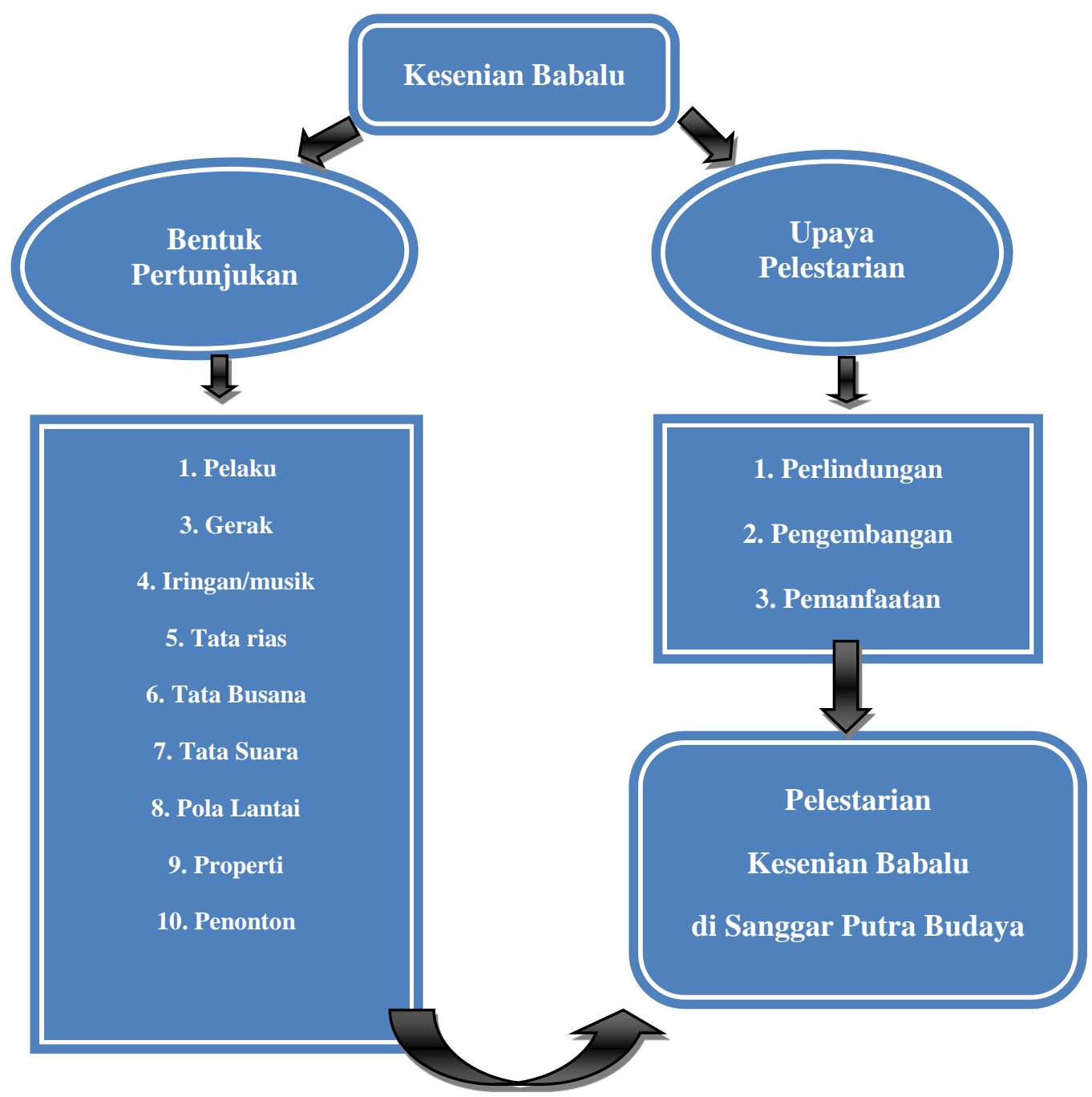

Bagan 2.1. Kerangka Berfikir

Pelestarian Kesenian Babalu di Sanggar Putra Budaya

Desa Proyonanggan Kabupaten Batang

Sumber : Adilah Endarini, 2017 


\section{BAB 3 \\ METODE PENELITIAN}

\subsection{Metode Penelitian}

Penelitian ini menggunakan metode penelitian kualitatif dengan menggunakan pendekatan Etnokoreologi. Metode kualitatif yaitu penelitian yang menghasilkan data deskriptif berupa kata-kata tertulis atau lisan dari orang-orang dan perilaku yang diamati. Sifat data kualitatif yaitu data yang mempunyai kandungan kaya, multidimensional, dan kompleks (Soedarsono, 2001: 46)

Menurut Soedarsono (2001:15) pendekatan etnokoreologi merupakan pendekatan khusus untuk penelitian tari dengan kombinasi antara penelitian tekstual yang lengkap dalam analisis geraknya serta penelitian kontekstual yang menekankan pada aspek kesejarahan, ritual, psikologi, dan linguistik, bahkan juga perbandingan.

Sugiyono (2010: 14) mengatakan metode penelitian kualitatif sering disebut metode penelitian naturalistik karena penelitiannya dilakukan pada kondisi alamiah (natural setting). Metode penelitian merupakan cara ilmiah untuk mendapatkan data dengan tujuan dan kegunaan tertentu. Cara ilmiah adalah kegiatan penelitian yang didasarkan pada ciri-ciri keilmuan, yaitu rasional, empiris, dan sistematis. Rasional adalah kegiatan penelitian yang dilakukan dengan cara-cara yang masuk akal sehingga terjangkau oleh penalaran manusia. Empiris adalah cara-cara yang dilakukan yang dapat diamati oleh indera manusia, sehingga orang lain dapat mengamati dan mengetahui cara-cara yang 
digunakan. Sistematis adalah proses yang digunakan dalam penelitian menggunakan langkah-langkah tertentu yang berlogis (Sugiyono, 2010: 3).

Oleh karena itu, peneliti menggunakan metode penelitian kualitatif yang bersifat deskriptif dan pendekatan etnokoreologi dengan maksud menggambarkan atau mengkaji tentang Pelestarian Kesenian Babalu di Sanggar Putra Budaya Desa Proyonanggan Kabupaten Batang.

\subsection{Data dan Sumber Data}

\subsubsection{Lokasi Penelitian}

Lokasi penelitian yang dipilih yaitu Sanggar Putra Budaya tepatnya di Desa Proyonanggan Kabupaten Batang. Kabupaten Batang merupakan wilayah yang terletak di sebelah Barat provinsi Jawa Tengah dengan luas daerah 788.642,16 km2. Kota Batang merupakan Kota yang dekat dengan Kota Pekalongan dan berbatasan dengan Kabupaten Kendal. Alasan dipilihnya Desa Proyonanggan Kabupaten Batang karena Desa Proyonanggan merupakan daerah yang masih rutin dalam melaksanakan kegiatan pelestarian Kesenian Babalu.

\subsubsection{Sasaran Penelitian}

Sasaran penelitian yang diambil adalah mengenai Pelestarian Kesenian Babalu di Sanggar Putra Budaya Desa Proyonanggan Kabupaten Batang meliputi bentuk pertunjukan dan upaya pelestarian yang ada di Sanggar Putra Budaya Desa Proyonanggan Kabupaten Batang.

\subsubsection{Data}

Data merupakan sekumpulan kata-kata yang memusatkan perhatian pada hal yang berlangsung secara alamiah, karya-karya seni, orang-orang dan peristiwa yang 
biasa terjadi dalam latar belakang realistik. Data seni dikumpulkan dengan penekanan pada kasus-kasus khusus, yaitu suatu fenomena yang terfokus dan terbatas yang dilekatkan pada konteksnya (Rohidi, 2011: 220)

Data dalam penelitian Pelestarian Kesenian Babalu di Sanggar Putra Budaya dibagi menjadi data primer dan data sekunder sebagai berikut :

\section{Data Primer}

Data Primer, adalah data dalam bentuk verbal atau kata-kata yang diucapkan secara lisan, gerak-gerik atau perilaku yang dilakukan oleh subjek yang dapat dipercaya, yakni subjek penelitan atau informan yang berkenaan dengan variabel yang diteliti atau data yang diperoleh dari responden secara langsung (Arikunto, 2010:22).

Data Primer meliputi elemen Bentuk Pertunjukan yang ada pada pertunjukan Kesenian Babalu seperti ( pelaku, gerak, iringan, tata rias, tata busana, tata suara, dan penonton ) serta Upaya Pelestarian Kesenian Babalu di Sanggar Putra Budaya Desa Proyonanggan Kabupaten Batang.

\section{Data Sekunder}

Data Sekunder meliputi data pendukung yang digunakan untuk mengkaji Bentuk Pertunjukan dan Upaya Pelestarian Kesenian Babalu (Sejarah Kesenian Babalu, Sejarah Sanggar, dan Letak Geografis Sanggar Putra Budaya).

\subsubsection{Sumber Data}

Sumber Data untuk mendapatkan data mengenai Bentuk Pertunjukan dan Upaya Pelestarian Kesenian Babalu di Sanggar Putra Budaya Desa Proyonanggan Kabupaten Batang meliputi : 
1. Sumber Data Primer : Pencipta tari pada Kesenian Babalu yaitu Bapak Suprayetno S.Kar selaku penaggungjawab dan mantan ketua Sanggar, lalu pencipta sekaligus penari dalam Kesenian Babalu yaitu Ibu Suningsih S.Pd M.Si

2. Sumber Data Sekunder : Kepala Desa Proyonanggan Kabupaten Batang, Anggota Sanggar Putra Budaya dan Penonton.

Dalam hal data sekunder, peneliti memanfaatkan adanya teknologi canggih yang dikenal sebagai sarana internet dimana peneliti dapat mengakses segala informasi mengenai segala data-data yang ingin diketahui guna memperlancar serta lebih melengkapi data-data yang sudah disusun dan penelitian yang sedang dilakukan. Selain itu, terdapat beberapa data sekunder lainnya yaitu buku-buku atau pustaka yang digunakan guna lebih memperkaya serta mempermudah peneliti untuk mendapatkan referensi untuk menganalisis hasil penelitian yang telah dilakukan.

\subsection{Teknik Pengumpulan Data}

Teknik pengumpulan data merupakan cara yang digunakan peneliti untuk mendapatkan data dalam suatu penelitian. Dalam tata cara memperoleh atau mengambil data dari lapangan peneliti menggunakan beberapa instrumeninstrumen penelitian yang telah disiapkan sebelumnya, sesuai pendekatan yang dipilih adalah kualitatif sehingga dalam instrumen yang cocok adalah observasi, wawancara, dan telaah dokumen.

\subsubsection{Teknik Observasi}

Observasi merupakan pengamatan yang bertujuan untuk mendapatkan data yang dibutuhkan dalam penelitian "Pelestarian Kesenian Babalu di Sanggar Putra 
Budaya Desa Proyonanggan Kabupaten Batang” sehingga diperoleh pemahaman atau pembuktian terhadap informasi sanggar atau keterangan yang diperoleh dari Sanggar Putra Budaya.

Observasi menurut Miles dan Huberman terjemahan Rohidi (2011: 182) adalah pengamatan sesuatu, seseorang, suatu lingkungan, atau situasi secara tajam dan terperinci, dan mencatatnya secara akurat dalam beberapa cara untuk memperoleh data tentang karya seni dalam suatu kegiatan dan situasi yang relevan dengan masalah penelitian.

Observasi dalam penelitian ini menggunakan langkah-langkah sebagai berikut : (1) Menyiapkan alat dan bahan yang digunakan untuk observasi seperti media rekam, kamera dan alat tulis, (2) Menyiapkan daftar data yang diambil ketika observasi, (3) Mencatat hal-hal yang berkaitan dengan Kesenian Babalu dan kegiatan pelestarian Kesenian Babalu di Sanggar Putra Budaya.

Adapun hal-hal yang diobservasi meliputi : Kondisi Sanggar Putra Budaya, Bentuk pertunjukan Kesenian Babalu, Lokasi Sanggar, serta kegiatan pelatihan di Sanggar Putra Budaya. Observasi Penelitian Kesenian Babalu di Sanggar Putra Budaya Desa Proyonanggan Kabupaten Batang dilakukan pada pementasan Kesenian Babalu, guna mengambil data primer yang berkaitan dengan bentuk pertunjukan dan upaya pelestarian Kesenian Babalu. Selain itu observasi juga dilakukan dalam kegiatan pelatihan di Sanggar Putra Budaya bersama dengan Bapak Suprayetno selaku ketua sanggar sekaligus pelatih tari guna mengambil data sekunder pendukung data primer seperti Sejarah Kesenian Babalu, Sejarah 
Sanggar, unsur-unsur pendukung Kesenian Babalu dan Letak Geografis Sanggar Putra Budaya.

Dalam melakukan observasi diperlukan alat dan bahan untuk membantu pengambilan data tentang Pelestarian Kesenian Babalu diantaranya yaitu (1) Alat tulis berupa buku catatan dan pena, (2) Alat rekam berupa telepon genggam (3) Kamera digital dan, (4) Alat transportasi untuk menuju ke lokasi.

\subsubsection{Wawancara}

Wawancara menurut Miles dan Huberman terjemahan Rohidi (2011:208209) adalah suatu teknik yang digunakan untuk memperoleh informasi secara tepat dan akurat. Sebuah wawancara merupakan metode pengumpulan data yang dapat digambarkan sebagai sebuah interaksi yang melibatkan pewawancara dengan yang diwawancarai, dengan maksud mendapatkan informasi yang sah dan dapat dipercaya. Wawancara berarti pengambilan data melalui pertanyaan yang diajukan secara lisan kepada responden.

Langkah-langkah dalam melakukan wawancara yaitu menyiapkan peralatan yang akan digunakan untuk wawancara seperti media rekam, kamera, alat tulis, lalu menyiapkan daftar pertanyaan yang ditanyakan ketika wawancara berlangsung, kemudian mencatat hasil wawancara, menganalisis hasil wawancara dan memasukkan hasil wawancara kedalam deskripsi penelitian.

Adapun narasumber yang diwawancarai dalam penelitian Pelestarian Kesenian Babalu yang pertama yaitu Bapak Suprayetno S.Kar selaku Ketua Sanggar Putra Budaya mengenai sejarah Kesenian Babalu, sejarah Sanggar Putra Budaya, dan struktur organisasi Sanggar Putra Budaya. 
Narasumber selanjutnya yaitu Ibu Suningsih selaku pelatih sekaligus penari dalam kesenian Babalu yang membahas mengenai pemeliharaan kesenian Babalu, pementasan kesenian Babalu, kendala dalam pelatihan, nama gerak dalam kesenian Babalu dan perkembangan gerak dalam kesenian Babalu. Narasumber berikutnya yaitu pemusik kesenian babalu serta penonton yang menikmati pertunjukan kesenian Babalu.

Materi wawancara dalam penelitian meliputi sejarah kesenian Babalu, bentuk pertunjukan dalam kesenian Babalu, kegiatan pemeliharaan kesenian Babalu, pementasan kesenian Babalu, perkembangan kesenian Babalu, perlengkapan kostum kesenian Babalu, dan musik pengiring kesenian Babalu. Adapun alat dan bahan yang digunakan dalam melakukan wawancara tentang kesenian Babalu yaitu alat tulis berupa buku dan pena, kamera, alat perekam video, alat perekam audio berupa telepon genggam dan daftar pertanyaan.

Wawancara yang digunakan dalam penelitian ini adalah wawancara terstruktur yaitu peneliti membawa pertanyaan yang merupakan garis besar tentang hal yang akan diteliti. Pertanyaan ini secara khusus ditujukan kepada informan peneliti, yaitu Bapak Suprayetno selaku Pendiri Sanggar Putra Budaya serta Ibu Suningsih selaku pelatih tari Babalu di Sanggar Putra Budaya. Metode pencatatan dalam penelitian ini menggunakan media pencatat berupa buku tulis, bolpoint, penghapus dan alat pembantu berupa kamera. Dengan menggunakan media peneliti berharap dapat memperoleh data yang jelas dan valid serta sebagai bukti dari pelaksanaan penelitian terhadap Upaya Pelestarian Kesenian Babalu di Sanggar Putra Budaya. 


\subsubsection{Dokumentasi}

Dokumen merupakan cacatan peristiwa yang sudah berlalu yang berbentuk tulisan, gambar atau karya-karya. Dokumen yang berbentuk tulisan misalnya cacatan harian, sejarah kehidupan, cerita, biografi, peraturan dan kebijakan. Lalu dokumen yang berbentuk gambar misalnya foto, gambar hidup dan sketsa. Dokumen yang berbentuk karya misalnya karya seni, yang berupa gambar, patung, film (Sugiyono 2010: 329).

Teknik dokumentasi adalah mencari data mengenai hal-hal yang berupa catatan, transkip, buku, surat kabar, majalah, prasasti, notulen rapat, agenda dan sebagainya. Metode dokumentasi dilakukan untuk mencari bukti penelitian yang dapat disimpan untuk menghindari kemungkinan hilangnya data dari informan. Hasil dari beberapa dokumentasi yang ada akan diolah atau diorganisasikan sedemikian rupa sehingga menjadi data yang dapat mendukung dan melengkapi data yang telah diperoleh dari metode observasi dan wawancara.

\subsection{Teknik Analisis Data}

Menurut Miles dan Huberman terjemahan Rohidi (2011: 234-240) analisis data digambarkan dalam tiga alir utama, yaitu: reduksi data, penyajian data dan penarikan kesimpulan dari dua yang pertama, dan telah memberi kerangka dasar bagi analisis yang dijalankan.

\subsubsection{Reduksi Data}

Reduksi data adalah struktur atau peralatan yang memungkinkan kita untuk memilah, memilih, memusatkan perhatian, mengatur, dan menyederhanakan data. Reduksi data dimaknai sebagai proses pemilihan, pemusatan perhatian pada 
penyederhanaan, pengabstrakan dan transformasi data "kasar" yang muncul dari catatan-catatan tertulis di lapangan.

Reduksi data yang dilakukan dalam penelitian Pelestarian Kesenian Babalu di Sanggar Putra Budaya Desa Proyonanggan Kabupaten Batang meliputi proses pengumpulan data sampai akhir yang dilakukan dengan cara observasi, wawancara, dan dokumentasi, kemudian diorganisir menjadi satu selanjutnya dianalisis.

\subsubsection{Penyajian Data}

Penyajian data adalah suatu penyajian sekelompok infomasi yang tersusun yang memberi kemungkinan adanya penarikan kesimpulan dan pengambilan tindakan. Dengan melihat melihat penyajian data kita akan memperoleh pemahaman tentang apa yang sedang terjadi dan apa yang harus dilakukan ( lebih jauh mengananlisis atau mengambil tindakan) berdasarkan atas pemahaman yang diperoleh dari penyajian data.

Penyajian data yang dilakukan dalam penelitian meliputi penarikan kesimpulan yang diperoleh dari hasil kegiatan observasi dan wawancara. Selanjutnya, peneliti menyajikan dalam bentuk uraian kalimat yang didukung dengan adanya dokumen berupa foto untuk menjaga validitas semua yang tersaji.

\subsubsection{Penarikan Kesimpulan}

Penarikan kesimpulan merupakan sebagian dari suatu kegiatan konfigurasi yang utuh. Kesimpulan-kesimpulan yang didapat selama penelitian mungkin berlangsung singkat dalam pemikiran penganalisis ketika menulis dengan menelaah ulang catatan-catatan lapangan. Namun juga berlangsung lama karena peneliti 
memerlukan banyak waktu dan tenaga dengan peninjauan kembali secara teliti dan berhati-hati.

Peneliti melakukan penarikan kesimpulan dan verifikasi tentang pelestarian kesenian Babalu di sanggar Putra Budaya setelah mereduksi data dan memfokuskan hal-hal yang terkait dan penyajian data dengan seluruh data yang diperoleh disajikan secara teks yang bersifat naratif, kemudian peneliti menarik kesimpulan sesuai dengan masalah yang digunakan dengan kenyataan yang dilakukan di lapangan.

Adapun Kerangka analisis data menurut Miles dan Huberman terjemahan Tjejep Rohendi Rohidi (2011: 240) ditunjukan dengan gambar berikut:

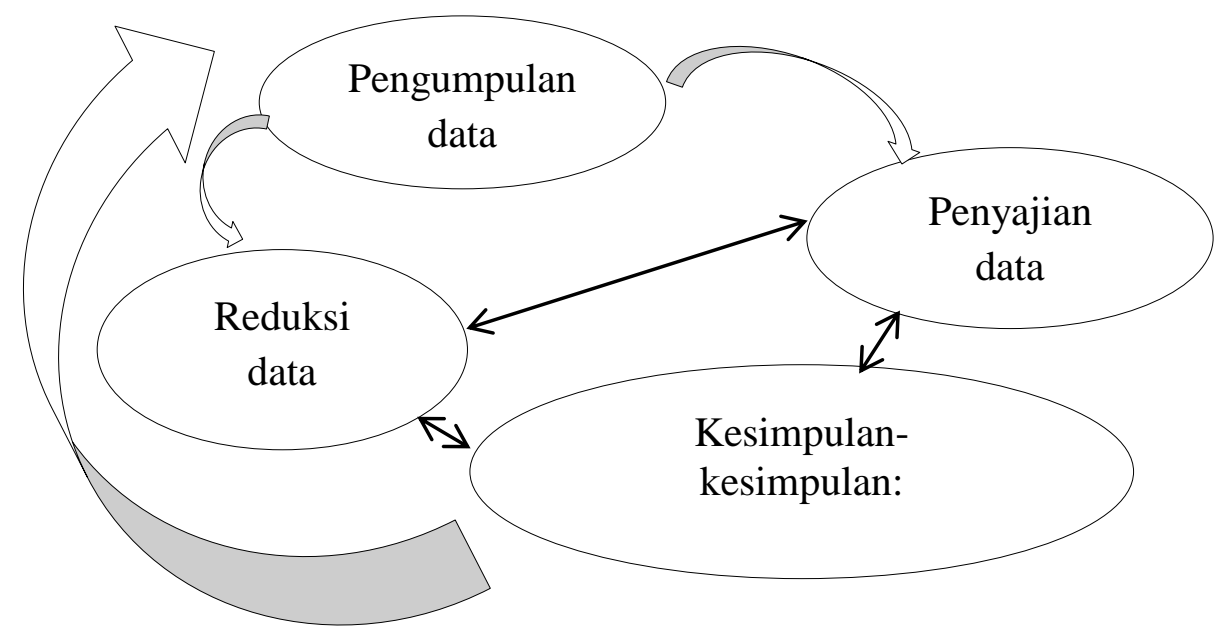

Bagan 2. Model Interaktif Analisis Data (Miles dan Huberman terjemahan Rohidi 2011: 240)

\subsection{Teknik Keabsahan Data}

Triangulasi dalam pengujian kredibilitas diartikan sebagai pengecekan data dari berbagai sumber dengan berbagai cara dan berbagai waktu. Dengan demikian 
terdapat triangulasi sumber, triangulasi teknik pengumpulan data, dan waktu. (Wiliam dalam Sugiyono 2010: 372).

\subsubsection{Triangulasi Sumber}

Triagulasi sumber untuk menguji kredibilitas data dilakukan dengan cara mengecek data yang telah diperoleh melalui beberapa sumber. Untuk menguji kredibilitas data tentang pelestarian Kesenian Babalu di sanggar putra budaya Kabupaten Batang, maka dilakukan pengumpulan data dan pengujian data yang telah diperoleh dari ketua, pemusik dan penari Kesenian Babalu. Ketiga sumber tersebut tidak bisa dirata-ratakan seperti dalam penelitian kuantitatif, tetapi dideskripsikan, dikategorisasikan, mana pandangan yang sama, yang berbeda, dan mana spesifikasi dari tiga sumber data tersebut. Data yang telah dianalisis oleh peneliti sehingga menghasilkan suatu kesimpulan selanjutnya dimintakan kesepakatan dengan tiga sumber data tersebut.

\subsubsection{Triangulasi Teknik}

Triangulasi teknik untuk menguji kredibilitas data dilakukan dengan cara mengecek data kepada sumber yang sama dengan teknik yang berbeda. Misalnya data diperoleh dengan wawancara, lalu dicek dengan observasi, dokumentasi, atau kuesioner. Bila dengan tiga teknik pengujian kredibilitas data tersebut menghasilkan data yang berbeda-beda, maka peneliti melakukan diskusi lebih lanjut kepada sumber data yang bersangkutan atau yang lain untuk memastikan data mana yang dianggap benar.

Pengecekan dalam penelitian ini dilakukan dengan cara: peneliti melakukan wawancara kemudian dicek dengan teknik observasi dan dokumentasi. Misal, 
wawancara dengan Bapak Suprayetno tentang Pelestarian Kesenian Babalu di Sanggar Putra Budaya juga harus dicocokan kembali dengan teknik dokumentasi yang terdapat di lapangan. Peneliti melakukan cek ulang dengan hasil video rekaman pertunjukan kesenian Babalu. Selain itu peneliti melakukan wawancara dengan informan lain misalnya Ibu Suningsih selaku pelatih tari Babalu, dan kemudian ditarik sebuah kesimpulan.

\subsubsection{Tringulasi Waktu}

Waktu juga sering mempengaruhi kredibilitas data. Data yang dikumpulkan dengan teknik wawancara yang dilakukan pagi hari saat narasumber masih segar, belum banyak masalah, akan memberikan data yang lebih valid sehingga lebih kredibel. Dalam rangka pengujian kredibilitas data dapat dilakukan dengan cara melakukan pengecekan dengan wawancara, observasi atau teknik lain dalam waktu atau situasi yang berbeda. Bila hasil uji menghasilkan data yang berbeda, maka dilakukan secara berulang-ulang sehingga sampai ditemukan kepastian data. 


\section{BAB 4}

\section{HASIL PENELITIAN DAN PEMBAHASAN}

\subsection{Gambaran Umum Lokasi Penelitian}

\subsubsection{Letak dan Kondisi Geografis Kabupaten Batang}

Kabupaten Batang merupakan tempat yang terletak di Ujung Barat Laut wilayah Kabupaten, yakni tepat di sebelah Timur Kota Pekalongan serta terletak pada $6^{\circ} 51^{\prime} 46^{\prime \prime}$ sampai $7^{\circ} 11^{\prime} 47^{\prime \prime}$ Lintang Selatan dan antara $109^{\circ} 40^{\prime} 19^{\prime \prime}$ sampai $110^{\circ} 03^{\prime} 06^{\prime \prime}$ Bujur Timur pantai utara Jawa Tengah dan berada pada jalur utama yang menghubungkan Jakarta-Surabaya. Luas daerah Kabupaten Batang yaitu 78.864,16 Ha.

Batas-batas wilayah Kabupaten Batang yaitu berada di sebelah Utara Laut Jawa, sebelah Timur Kabupaten Kendal, sebelah Selatan Kabupaten Wonosobo dan Kabupaten Banjarnegara serta sebelah Barat Kota Pekalongan dan Kabupaten Pekalongan. Kondisi wilayah Kabupaten Batang merupakan kombinasi antara daerah pantai, dataran rendah dan pegunungan. Dengan kondisi tersebut Kabupaten Batang mempunyai potensi yang sangat besar untuk agroindustri, agrowisata dan agrobisnis.

Berikut Foto 4.1 adalah peta lokasi Kabupaten Batang Jawa Tengah Indonesia yang terdiri dari 15 Kecamatan yang terdiri dari Desa dan Kelurahan serta pusat pemerintahan yang berada di Kecamatan Batang tepatnya di wilayah Alun-alun Kabupaten Batang. Adapun nama-nama kecamatan diantaranya yaitu 
Kecamatan Batang, Warungasem, Wonotunggal, Bandar, Blado, Reban, Bawang, Tersono, Gringsing, Limpung, Subah, Tulis, Kandeman, Pecalungan dan Banyuputih.

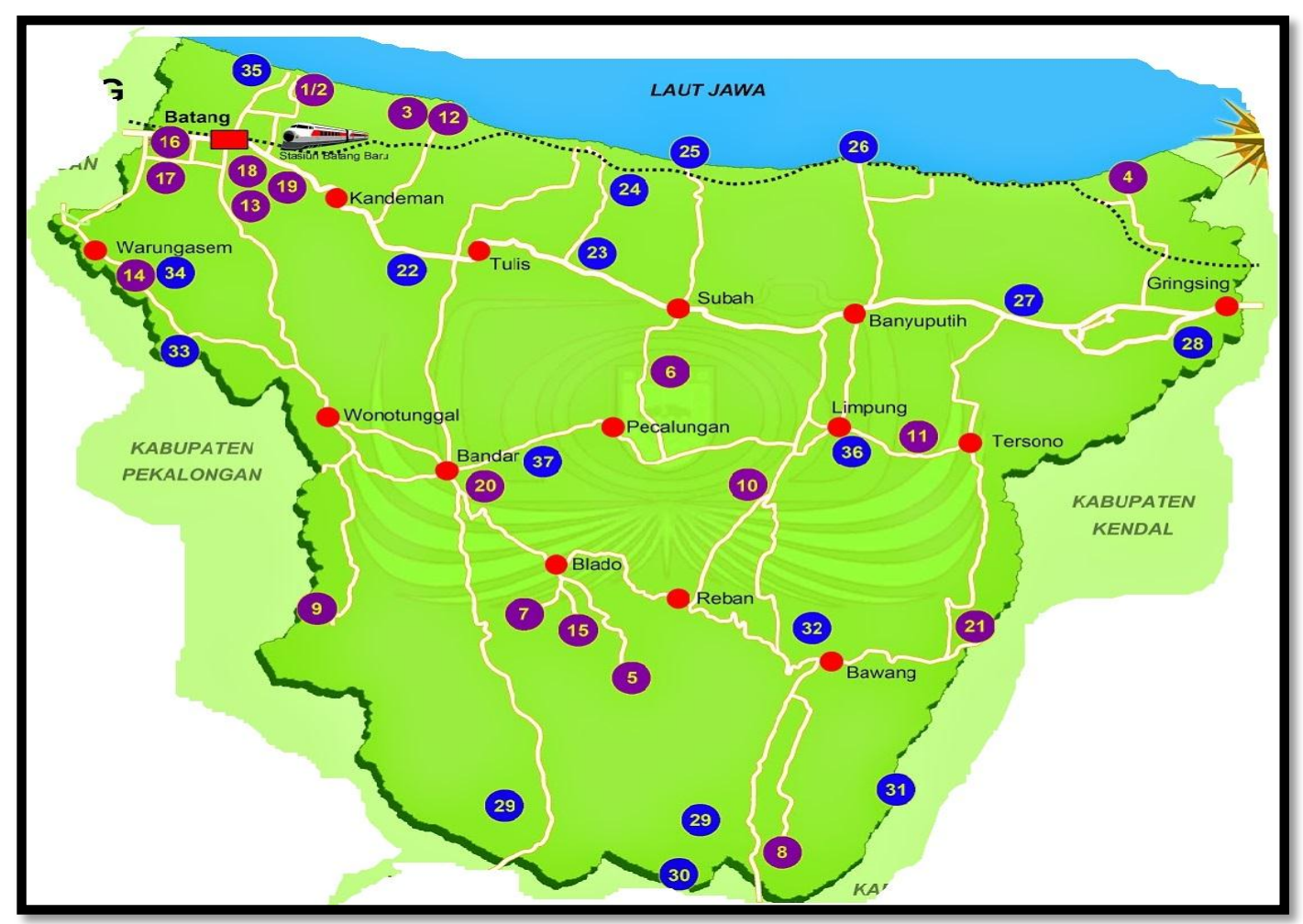

Foto 4.1 Peta Kabupaten Batang Jawa Tengah Sumber : (http://Peta_kabupaten_Batang) di unduh tanggal 17 April 2017

Foto 4.1 merupakan peta Kabupaten Batang yang terdiri dari 15 Kecamatan. Adapun penjelasan wilayah yang terdapat dalam foto 4.1 yaitu pada nomer 6 merupakan wilayah Kecamatan Batang, nomer 19 merupakan Kecamatan Kandeman, nomer 14 merupakan Kecamatan Warungasem, nomer 22 merupakan Kecamatan Tulis lalu nomer 6 merupakan Kecamatan Subah, nomer 37 merupakan Kecamatan Pecalungan, nomer 20 merupakan Kecamatan Bandar, nomer 33 
merupakan Kecamatan Wonotunggal, nomer 7 merupakan Kecamatan Blado, nomer 10 merupakan Kecamatan Reban, nomer 32 merupakan Kecamatan Bawang, nomer 11 merupakan Kecamatan Tersono, nomer 36 merupakan Kecamatan Limpung, nomer 27 adalah Kecamatan Banyuputih, dan nomer 28 merupakan wilayah Kecamatan Gringsing

Nomer 16 adalah Kecamatan Batang yang berada di Kota Kabupaten Batang. Kecamatan Batang merupakan wilayah yang strategis karena berada di daerah perkotaan yang dekat dengan Kabupaten Pekalongan serta berada pada jalur ekonomi Pulau Jawa sebelah Utara. Kesenian yang masih berkembang di Kabupaten Batang yaitu Kesenian Babalu yang berada di Desa Proyonanggan Kecamatan Batang Kabupaten Batang. Kesenian Babalu tumbuh dan berkembang di wilayah Ibu Kota Kabupaten Batang tepatnya di Sanggar Putra Budaya Desa Proyonanggan Kabupaten Batang yang berlokasi di Pendopo Kelurahan Desa Proyonanggan.

Pusat Ibu Kota Kabupaten Batang terdapat di wilayah Alun-alun Kabupaten Batang yang berada di Jalur Pantura Jawa Tengah dan berbatasan dekat dengan Kota Pekalongan. Alun-alun Kabupaten Batang terletak diantara Jalan Ahmad Yani lalu Jalan Diponegoro, Jalan Brigjend Katamso dan Jalan Jendral Sudirman Kabupaten Batang.

Berikut foto 4.2 merupakan denah Lokasi menuju ke daerah Ibukota Kabupaten Batang yang dimulai dari arah Semarang Kota lalu melewati Kota Kendal dan menuju ke arah Ibukota Kabupaten Batang (Alun-alun Batang) yang dekat dengan Perbatasan Kabupaten Pekalongan Jawa Tengah. 


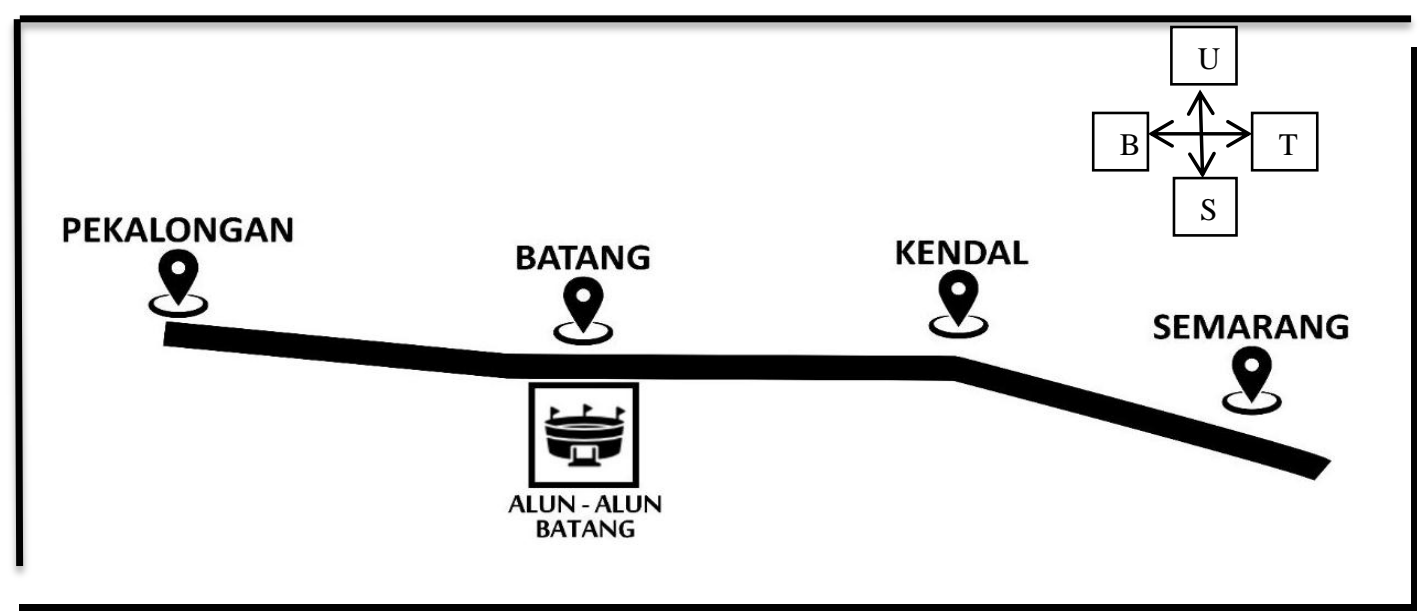

Foto 4.2 Peta Lokasi Semarang ke Kabupaten Batang Sumber : Adilah Endarini, 8 Juli 2017

Foto 4.2 merupakan peta lokasi yang menunjukan letak Kota Semarang menuju ke arah Kabupaten Batang yang dapat ditempuh dengan waktu kira-kira sekitar 2 jam lebih 16 menit. Perjalanan menuju Kota Batang menggunakan Jalur Pantura yang dimulai dari Kota Semarang menuju kearah Barat lalu melewati Kota Kendal menuju ke arah Alun-alun Kabupaten Batang. Keberadaan Alun-alun Batang dapat ditemui di Kiri Jalan Pantura dekat dengan Masjid Agung Kabupaten Batang dan dekat dengan Rumah Dinas Bupati Batang. Lokasi tempat pelatihan Kesenian Babalu berada di Sanggar Putra Budaya Desa Proyonanggan Tengah Kabupaten Batang yang dapat di tempuh sekitar lima menit dari arah Alun-alun Kabupaten Batang.

Berikut foto 4.3 Peta Lokasi Letak Desa Proyonanggan Tengah (Central Proyonanggan) yang dimulai dari arah Alun-alun Kabupaten Batang menuju kearah Pendopo Kelurahan Desa Proyonanggan Kabupaten Batang. 


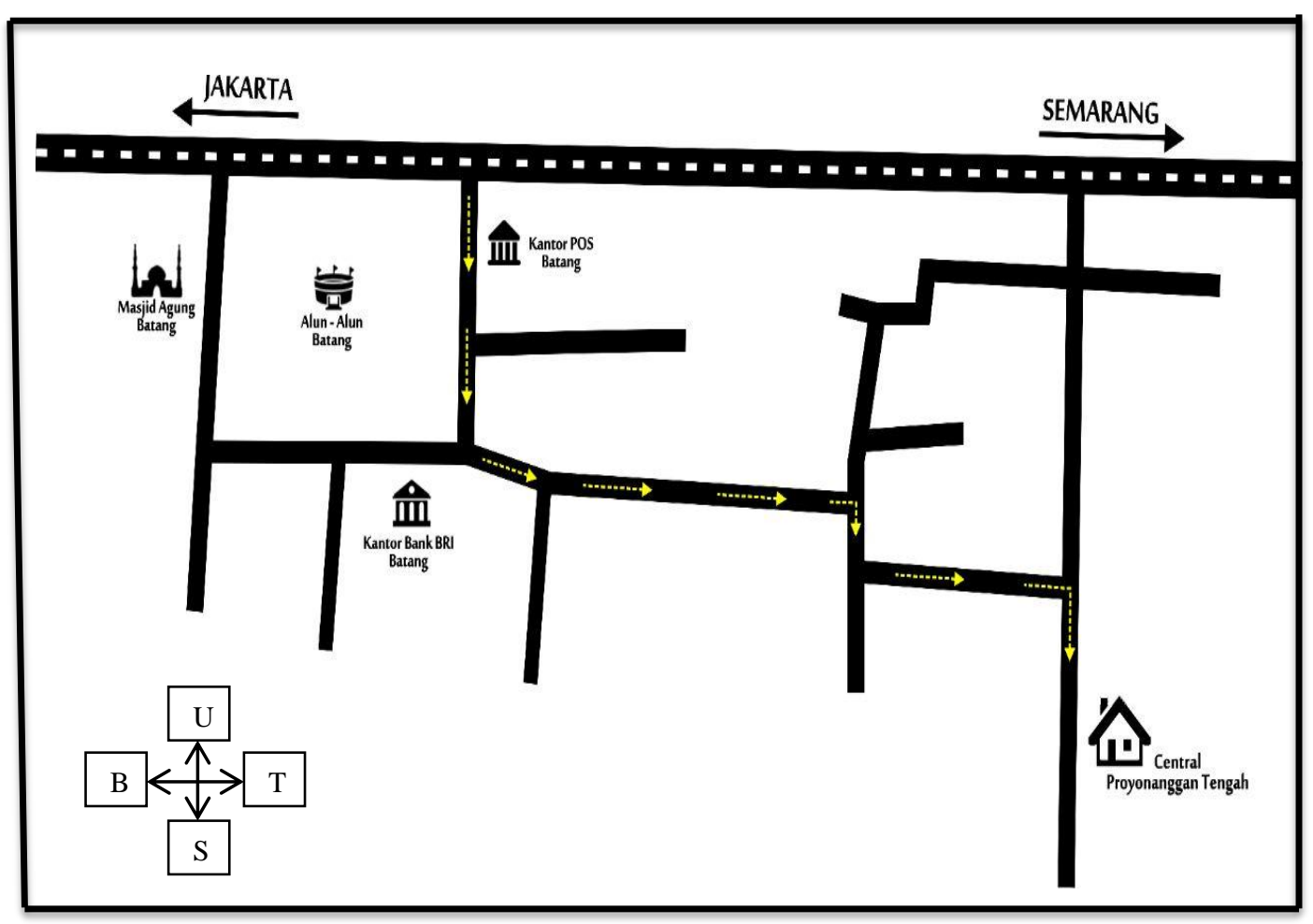

Foto 4.3

Peta Lokasi Kabupaten Batang ke Desa Proyonanggan Tengah Sumber : Adilah Endarini, 8 Juli 2017

Pada foto 4.3 merupakan Peta Lokasi Kabupaten Batang yang dimulai dari Alun-alun Batang menuju ke Desa Proyonanggan Tengah melewati Jalan samping kanan Kantor Bank BRI Batang kemudian lurus sampai terdapat pertigaan jalan lalu belok ke arah kanan. Setelah belok kanan lalu sekitar 200 meter mengikuti tanda panah kemudian belok kiri dan lurus, selanjutnya menemui pertigaan jalan lalu belok ke arah kanan di Jalan Dokter Cipto yang merupakan lokasi pusat Desa Proyonanggan Tengah Kabupaten Batang. Desa Proyonanggan Tengah mempunyai beberapa Kesenian yaitu Kesenian Babalu, Kesenian Sintren, Kesenian Kuda Lumping dan Ketoprak Jawa, selain itu Desa Proyonanggan juga merupakan desa 
yang mendukung aktivitas Kesenian Babalu. Adapun Keberadaan Pelestarian Kesenian Babalu yaitu di Sanggar Putra Budaya yang bertempat di Kantor Kelurahan Desa Proyonanggan Tengah Kabupaten Batang.

\subsubsection{Desa Proyonanggan Kabupaten Batang}

Desa Proyonanggan merupakan desa yang berada diwilayah Kecamatan Batang yang dekat dengan pusat kota yaitu Alun-alun Batang. Desa Proyonanggan berada di Jalan Dr.Cipto yang dekat dengan Pasar Batang dan Puskesmas Desa Proyonanggan. Sebagian besar penduduk Desa Proyonanggan Kabupaten Batang mempunyai matapencahariaan sebagai petani, guru, pegawai swasta, dan buruh. Desa Proyonanggan merupakan desa yang mendukung dan berperan dalam perkembangan Kesenian Babalu di Sanggar Putra Budaya Kabupaten Batang. Bukti peran serta Desa Proyonanggan dalam melestarikan Kesenian Babalu di Sanggar Putra Budaya yaitu Desa Proyonanggan menyediakan tempat berupa Pendopo yang dijadikan sebagai tempat pelatihan Kesenian Babalu di Kabupaten Batang.

Antusias masyarakat Desa Proyonanggan Kabupaten Batang terhadap Kegiatan pelatihan Kesenian Babalu dan kesenian-kesenian yang lain sangat baik, hal ini dapat dilihat apabila penduduk Desa Proyonanggan Kabupaten Batang yang memiliki hajatan atau acara tertentu banyak mendatangkan kelompok kesenian yang berasal dari Desa Proyonanggan sendiri ataupun dari desa-desa lain di wilayah Kabupaten Batang. Adapun Kesenian yang pernah di tanggap seperti Kesenian Babalu, Kesenian Sintren, Ketoprak, Kesenian Tari, Wayang dan Musik Dangdut. 
Desa Proyonanggan Kabupaten Batang mempunyai kesenian yang masih tetap aktif dan berkembang dalam kegiatan keseniannya yaitu Kesenian Babalu. Keberadaan Kesenian Babalu di Sanggar Putra Budaya Desa Proyonanggan Kabupaten Batang jauh lebih berkembang jika dibandingkan dengan keseniankesenian lainnya diantaranya yaitu Kesenian Sintren, Ketoprak dan Wayang. Kesenian Babalu yang berasal dari Kabupaten Batang dan sampai saat ini masih dilestarikan di Sanggar Putra Budaya merupakan Kesenian yang dahulunya ditampilkan oleh seorang prajurit atau para pejuang Kemerdekaan Indonesia dalam melawan sekelompok penjajah.

Kesenian Babalu merupakan Kesenian yang menggambarkan para pejuang Kabupaten Batang dalam melawan penjajah yang dilakukan dengan menggunakan suatu gerakan yang telah disepakati bersama oleh para pejuang untuk memperdayai para penjajah yang memperkuat Kabupaten Batang. Pada tahun 1999-2000 Kesenian Babalu mengalami perkembangan yaitu pelaku kesenian yang terdapat dalam suatu pementasan Kesenian Babalu tidak hanya dilakukan pada kalangan prajurit saja namun juga di kalangan anak-anak tamat SLTA, tamat akademik dengan jumlah usia sekitar 18-35 tahun melalui kegiatan-kegiatan pelatihan yang diadakan di Sanggar Putra Budaya Desa Proyonanggan Kabupaten Batang. Adapun Data Kependudukan Desa Proyonanggan Kabupaten Batang yaitu sebagai berikut :

\subsubsection{Data Kependudukan Desa Proyonanggan Kabupaten Batang}

Jumlah Penduduk Desa Proyonanggan Kabupaten Batang berjumlah 9.995 jiwa dengan rincian jumlah laki-laki 4.963 jiwa dan jumlah perempuan 5.032 jiwa. 
Jika dikelompokan sesuai dengan umur maka jumlah umur masyarakat Desa Proyonanggan Kabupaten Batang dapat dilihat sebagai berikut :

Tabel 4.1 Jumlah Penduduk Kelompok Umur Desa Proyonanggan Tengah

\begin{tabular}{|c|c|c|c|}
\hline Kelompok Umur & Laki-laki & Perempuan & Jumlah \\
\hline$(1)$ & $(2)$ & $(3)$ & $(4)$ \\
\hline $0-4$ & 338 & 320 & 658 \\
$15-9$ & 377 & 352 & 729 \\
$10-14$ & 382 & 381 & 763 \\
$15-19$ & 387 & 368 & 755 \\
$20-24$ & 369 & 329 & 698 \\
$25-29$ & 405 & 299 & 704 \\
$30-39$ & 653 & 716 & 1.363 \\
$40-49$ & 774 & 776 & 1.550 \\
$50-59$ & 570 & 683 & 1.253 \\
$60+$ & 708 & 808 & 1.516 \\
\hline Jumlah & 4.963 & 5.032 & 9.989 \\
\hline
\end{tabular}

(Sumber : Data Statistik Desa Proyonanggan Tengah Kabupaten Batang, Tahun 2017).

Tabel 4.1 menunjukan bahwa jumlah penduduk Desa Proyonanggan Tengah Kabupaten Batang dalam tabel tersebut yang paling banyak adalah umur $40-49$ tahun (dewasa) yakni berjumlah 1.550 jiwa sedangkan untuk usia diatas 60+ (manula) berjumlah 1.516 jiwa, untuk usia 15 - 19 tahun (remaja) berjumlah 755 jiwa. Tabel jumlah penduduk menurut kelompok umur sangat berpengaruh terhadap upaya pelestarian Kesenian Babalu, hal ini dapat dilihat dari usia masyarakat Desa Proyonanggan Kabupaten Batang yang sebagian besar adalah remaja, dewasa dan manula.

Kesenian Babalu dalam perkembangannya mendominasi para pemain Kesenian Babalu yang berusia di sekitar usia remaja, usia dewasa dan usia manula, 
dimana ketiga kelompok umur tersebut saling mengisi satu sama lain dalam berbagai hal mengenai upaya pelestarian Kesenian Babalu di Sanggar Putra Budaya Desa Proyonanggan Kabupaten Batang. Namun tidak jarang pula usia pra remaja antara usia 10-14 tahun juga ikut serta dalam upaya melestarikan Kesenian Babalu di Kabupaten Batang

\subsubsection{Agama Masyarakat Proyonanggan}

Agama masyarakat Desa Proyonanggan Tengah Kabupaten Batang berbeda-beda yang terdiri dari Agama Islam, Katholik, Kristen, Hindu, Budha serta Konghucu. Jumlah total masyarakat Desa Proyonanggan yang mempunyai agama yaitu 10.797 jiwa dengan rincian sebagai berikut :

Tabel 4.2 Jumlah Penduduk Desa Proyonanggan Menurut Agama

\begin{tabular}{|c|c|c|}
\hline & Agama & Jumlah \\
\hline 1. & Islam & 10.305 \\
2. & Katholik & 293 \\
3. & Kristen & 146 \\
4. & Hindu & 8 \\
5. & Budha & 37 \\
6. & Konghucu & 8 \\
\hline
\end{tabular}

(Sumber : Data Statistik Desa Proyonanggan Tengah Kabupaten Batang, Tahun 2017)

Aktivitas masyarakat di Desa Proyonanggan Kabupaten Batang berjalan lancar sesuai dengan kepercayaan yang dianut dan memiliki masyarakat yang berjiwa religius dalam kehidupan beragama. Tabel 4.2 menunjukan jumlah keseluruhan masyarakat kabupaten yang memeluk agama yaitu berjumlah 10.797 jiwa yang terdiri dari 10.305 jiwa penduduk Desa Proyonanggan memeluk Agama Islam, lalu 293 jiwa yang memeluk Agama Katholik, 146 jiwa memeluk Agama 
Kristen, 8 jiwa memeluk Agama Hindu, 37 jiwa memeluk Agama Budha dan 8 jiwa memeluk Agama Konghucu.

Bedasarkan data penduduk mayorias penduduk di Desa Proyonanggan memeluk Agama Islam, jadi agama yang diyakini oleh sebagian besar masyarakat di Desa Proyonanggan Kabupaten Batang adalah Agama Islam, hal ini dikarenakan faktor turun-temurun dari nenek moyang pada jaman dahulu yang juga memeluk Agama Islam.

Kesenian Babalu merupakan suatu kesenian yang dikembangkan kembali di Sanggar Putra Budaya Desa Proyonanggan Kabupaten Batang dengan nuansa Islami yang didukung oleh masyarakat Desa Proyonanggan dan para pecinta seni di Kabupaten Batang. Kesenian Babalu di Sanggar Putra Budaya Desa Proyonanggan Kabupaten Batang dalam proses perkembangannya dikemas dalam sajian Islami dengan menggunakan lagu Babalu Mbatang serta lagu Lir-ilir dengan nada sama seperti nada Sholawatan. Hal tersebut menunjukan bahwa perkembangan Kesenian Babalu di Sanggar Putra Budaya Desa Proyonanggan Kabupaten Batang tidak lepas dari unsur islami yang berkaitan dengan lingkungan tempat Kesenian Babalu berkembang.

\subsubsection{Tingkat Pendidikan Desa Proyonanggan Kabupaten Batang}

Tingkat Pendidikan masyarakat di Desa Proyonanggan Kabupaten Batang berbeda-beda mulai dari PAUD/TK, SD, SLTP, SLTA, D-1/D-2, D-3, S-1, dan S2. Perbedaan tingkat pendidikan menunjukan suatu minat dan kebiasaan yang berbeda pula dengan mengikuti suatu perkembangan kesenian yang ada. Tingkat pendidikan masyarakat yang sangat penting dalam membawa generasi muda menentukan masa 
depannya. Berikut tabel 4.3 jumlah penduduk menurut tingkat pendidikan yang terdapat di wilayah Desa Proyonanggan Kabupaten Batang terdiri dari Laki-laki dan Perempuan dengan Jumlah total yaitu sekitar 10.797 orang dengan rincian data sebagai berikut:

Tabel 4.3 Jumlah Penduduk Menurut Pendidikan

\begin{tabular}{|c|c|c|c|c|c|}
\hline \multirow{2}{*}{ NO } & \multirow{2}{*}{ TINGKAT } & \multicolumn{2}{|c|}{ PENDUDUK } & \multirow{2}{*}{ JUMLAH } & \multirow{2}{*}{ KETERANGAN } \\
\cline { 3 - 4 } & PENDIDIKAN & LK & PR & PENDUDUK & \\
\hline 1. & PAUD/ TK & 975 & 1016 & 1991 & - \\
2. & SD & 1274 & 1303 & 2577 & - \\
3. & SLTP & 878 & 838 & 1716 & - \\
4. & SLTA & 1562 & 1378 & 2940 & - \\
5. & D-1/D-2 & 16 & 28 & 44 & - \\
6. & D-3 & 78 & 123 & 201 & - \\
7. & S-1 & 357 & 336 & 693 & - \\
8. & S-2 & 24 & 11 & 35 & - \\
\hline \multicolumn{7}{|l}{ Jumlah } & \multicolumn{3}{l}{10.797} & \\
\hline
\end{tabular}

(Sumber : Data Monografi Desa Proyonanggan Tengah Kabupaten Batang, Tahun 2017)

Tabel 4.3 menunjukan bahwa data terbanyak masyarakat Desa Proyonanggan adalah pada tingkat pendidikan SLTA yang berjumlah 2490 jiwa, lalu dilanjutkan dengan jumlah pendidikan SD yang berjumlah 2577 jiwa serta data siswa PAUD/TK berjumlah 1991 jiwa. Jumlah masyarakat yang bersekolah di tingkat SD, SMP/SLTP dan SMA/SLTA lebih banyak dibandingkan dengan masyarakat yang bersekolah di Akademi, Sarjana, maupun Pasca Sarjana, oleh karena itu kegiatan pelatihan Kesenian Babalu di Sanggar Putra Budaya Desa Proyonanggan Kabupaten Batang lebih mudah diajarkan serta dilestarikan kepada masyarakat tingkat SD, SMP, SMA yang berusia produktif dan relatif muda 
dibandingkan dengan masyarakat yang sudah bersekolah di Akademi, Sarjana maupun Pasca Sarjana.

Upaya perlindungan Kesenian Babalu kepada masyarakat selain dari Sanggar Putra Budaya juga dapat dilakukan melalui lembaga pendidikan formal oleh Guru Seni Budaya di Kabupaten Batang, sehingga dalam bidang pendidikan disekolah kegiatan Pelestarian Kesenian Babalu dapat diterapkan sebagai materi tambahan dalam menunjang kegiatan pembelajaran.

\subsection{Sanggar Putra Budaya Desa Proyonanggan Kabupaten Batang}

Sanggar Putra Budaya merupakan tempat untuk melaksanakan kegiatan seni serta sebagai sarana pelestarian kesenian tradisional salah satunya yaitu Kesenian Babalu yang berasal dari Kabupaten Batang. Sanggar Putra Budaya tumbuh dan berkembang di Pendopo Kelurahan Desa Proyonanggan Tengah Kabupaten Batang sejak tahun 1985. Lokasi Sanggar Putra Budaya sangat strategis hal ini dikarenakan Sanggar Putra Budaya berada di daerah Kota yang dekat dengan Pasar Kota Batang dan Puskesmas Desa Proyonanggan Kabupaten Batang.

Berikut foto 4.4 merupakan denah untuk menuju ke lokasi kegiatan pelatihan Kesenian Babalu yang berada di Sanggar Putra Budaya Desa Proyonanggan Kabupaten Batang yang dimulai dari arah Pusat Desa Proyonanggan Tengah menuju ke Kantor Kelurahan Desa Proyonanggan yang berada di Jalan Dokter Cipto nomer 28 Desa Proyonanggan Kabupaten Batang Jawa Tengah. 


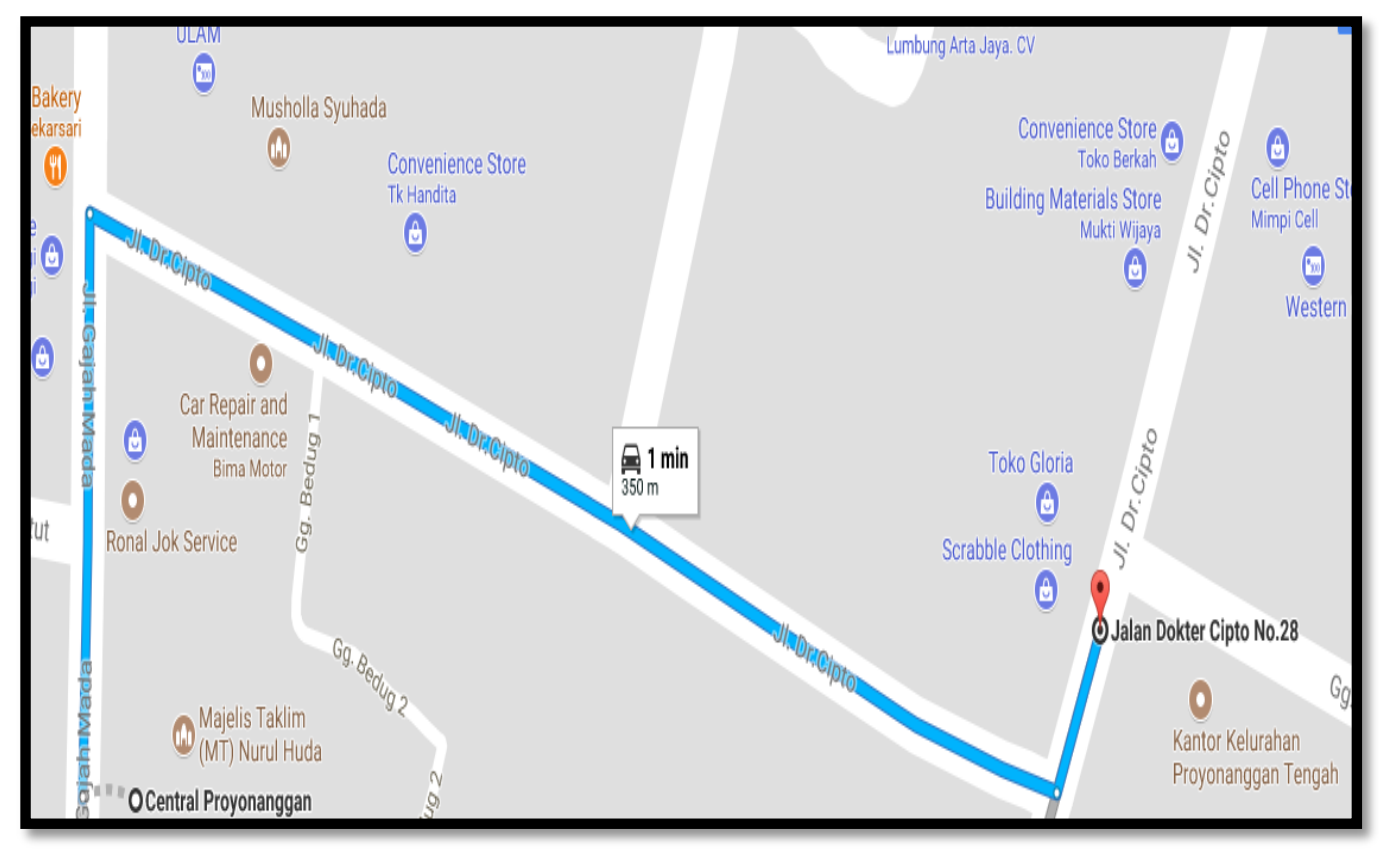

Foto 4.4 Peta Lokasi Kantor Kelurahan Proyonanggan

Sumber : (https://www.google.co.in/maps_batang) diunduh 8 Juli 2017

Foto 4.4 merupakan peta lokasi menuju tempat pelatihan Kesenian Babalu yaitu di Sanggar Putra Budaya yang bertempat di Pendopo Kelurahan Desa Proyonanggan Tengah Kabupaten Batang. Adapun alamat lengkap Pendopo Kleurahan Desa Proyonanggan Kabupaten Batang yaitu di Jalan Dr.Cipto No 28 yang berdekatan dengan SD Proyonanggan 06 serta Puskesmas Desa Proyonanggan Kabupaten Batang.

\subsubsection{Profil Sanggar Putra Budaya Desa Proyonanggan Kabupaten Batang}

Sanggar Putra Budaya Desa Proyonanggan Kabupaten Batang merupakan sanggar yang berada wilayah Proyonanggan Kabupaten Batang yang berdiri sejak tahun 1985 oleh tokoh seniman Batang yaitu Bapak Sukimto. Kata Putra Budaya mempunyai arti yaitu anak-anak berbudaya yang secara turun-temurun 
melanjutkan dan melestarikan budaya adiluhung agar tetap terjaga dan tidak punah seiring berjalannya waktu.

Berikut merupakan hasil observasi pada tanggal 3 April 2017 yang membahas tentang harapan Bapak Suprayetno kepada generasi muda mendatang dimana Bapak Suprayetno merupakan penanggung jawab Sanggar Putra Budaya serta tokoh yang berperan dalam pelestarian Kesenian Babalu di Sanggar Putra Budaya Desa Proyonanggan Kabupaten Batang, beliau mengatakan sebagai berikut :

“...saya berharap dengan adanya Sanggar Putra Budaya di Kabupaten Batang ini membuat generasi muda secara turun-temurun dapat melestarikan kesenian tradisi, supaya kesenian telah ada akan tetap terjaga keberadaannya serta tidak tergerus oleh budaya asing."

Sanggar Putra Budaya merupakan sanggar yang melatihkan Kesenian Babalu kepada masyarakat Kabupaten Batang. Sanggar Putra Budaya yang berada di Desa Proyonanggan Kabupaten Batang merupakan sanggar yang bergerak dalam pelatihan seni tari, keberadaan Sanggar Putra Budaya sangat membantu terhadap perkembangan Kesenian Babalu. Sanggar Putra Budaya Desa Proyonanggan Kabupaten Batang membagi 3 kelas tari yaitu kelas tari dasar, kelas tari lanjut dan kelas tari mahir. Pembagian kelas dilakukan agar pelatihan tari dapat berjalan dengan lancar efektif dan efisien. Materi yang diberikan di Sanggar Putra Budaya Desa Proyonanggan Kabupaten Batang yaitu Tari Golek Sri Rejeki, Tari Molek, Tari Merak, Tari Kelinci, serta kesenian tradisional kerakyatan khas Kabupaten Batang yaitu Kesenian Babalu. Pelatihan tari di Sanggar Putra Budaya Desa Proyonanggan Kabupaten Batang biasanya diawali dengan menarikan materi wajib berupa Kesenian Babalu sebelum memulai materi inti, hal ini dilakukan sebagai 
upaya untuk melestarikan Kesenian Babalu kepada siswa di Sanggar Putra Budaya.

\subsubsection{Struktur Organisasi Sanggar Putra Budaya Desa Proyonanggan.}

Struktur Organisasi Sanggar Putra Budaya Desa Proyonanggan Kabupaten Batang terdiri dari Pelindung Sanggar yaitu Kepala Kelurahan Desa Proyonanggan Tengah Kabupaten Batang, lalu penanggung jawab Sanggar yaitu Suprayetno, S.Kar, M.Si, Ketua Sanggar yaitu Riyanto S.Pd M.Si, Sekretaris Sanggar yaitu Suyanto S.Pd M.Si serta Bendahara Sanggar yaitu Sukiyanto, S.Pd M.Si. Adapun seksi-seksi di Sanggar Putra Budaya Desa Proyonanggan Kabupaten Batang di bagi menjadi tiga seksi yaitu : Seksi Kepelatihan oleh Suningsih, S.Pd M.Si dan Suyanti, S.Pd M.Pd, lalu Seksi Pementasan yaitu Dra. Sukowati, M.Si serta Seksi Humas yaitu Sinta Kusumawati, S.Pd.

Penanggungjawab Sanggar Putra Budaya Desa Proyonanggan Kabupaten Batang serta sekaligus pendiri Sanggar Putra Budaya dahulunya yaitu Bapak Sukimto namun Bapak Sukimto telah wafat dan digantikan oleh putranya yaitu Bapak Suprayetno. Kemudian Ketua Sanggar Putra Budaya yaitu Bapak Riyanto, Bapak Riyanto selaku Ketua Sanggar Putra Budaya memiliki tanggungjawab yang besar atas segala perkembangan yang terdapat Sanggar Putra Budaya serta melaporkan keberadaan Sanggar Putra Budaya Desa Proyonanggan Kabupaten Batang untuk setiap tahunnya ke Dinas Kebudayaan, Pariwisata, Pemuda dan Olahraga Kabupaten Batang.

Selain itu sebagai Ketua Sanggar Putra Budaya Desa Proyonanggan Kabupaten Batang, Bapak Riyanto bertugas untuk menyetujui atau mengesahkan 
kegiatan Sanggar Putra Budaya yang diadakan pada setiap tahunnya dengan hasil diskusi bersama dengan Bapak Suprayetno serta musyawarah oleh seluruh anggota Sanggar Putra Budaya yang berada di Desa Proyonanggan Kabupaten Batang. Pelatih Kesenian Babalu di Sanggar Putra Budaya Desa Proyonanggan Kabupaten Batang yaitu (Ibu Suningsih S.Pd M.Si dan Ibu Suyanti S.Pd M.Pd) kedua pelatih Sanggar Putra Budaya saling bertanggung jawab terhadap pelatihan Kesenian Babalu ataupun tari lain yang diajarkan di Sanggar Putra Budaya Kabupaten Batang. Pelatih tari memiliki tanggung jawab pada hasil pelatihan yang diajarkan oleh pelatih kepada siswa di Sanggar Putra Budaya Desa Proyonanggan Kabupaten Batang.

Para pelatih tari dalam kesenian Babalu memiliki tanggung jawab dalam pementasan-pementasan tari yang diadakan oleh Sanggar Putra Budaya Desa Proyonanggan Kabupaten Batang, adapun pementasan yang akan dilaksanakan oleh Sanggar Putra Budaya diantaranya adalah pemilihan siswa Sanggar dalam pementasan, pelatihan dan kematangan mental dalam pementasan Kesenian Babalu ataupun Kesenian-kesenian yang lain. Sanggar Putra Budaya yang berada di Desa Proyonanggan Kabupaten Batang mempunyai Struktur Organisasi yang terdiri dari Penanggung Jawab Sanggar Putra Budaya yaitu oleh Bapak Suprayetno.

Peran Bapak Suprayetno sangat penting dalam usaha pelestarian Kesenian Babalu di Sanggar Putra Budaya Desa Proyonanggan Kabupaten Batang. lalu selanjutnya yaitu dalam organisasi Sanggar Putra Budaya terdapat Ketua Sanggar Putra Budaya, Sekretaris Sanggar Putra Budaya, Bendahara Sanggar Putra Budaya, 
Seksi Kepelatihan Sanggar Putra Budaya, Seksi Pementasan Sanggar Putra Budaya, dan Seksi Humas Sanggar Putra Budaya Desa Proyonanggan Kabupaten Batang. Adapun Struktur Organisasi yang terdapat di Sanggar Putra Budaya Desa Proyonanggan Kabupaten Batang yaitu sebagai berikut :

Bagan 4.1 Struktur Organisasi Sanggar Putra Budaya

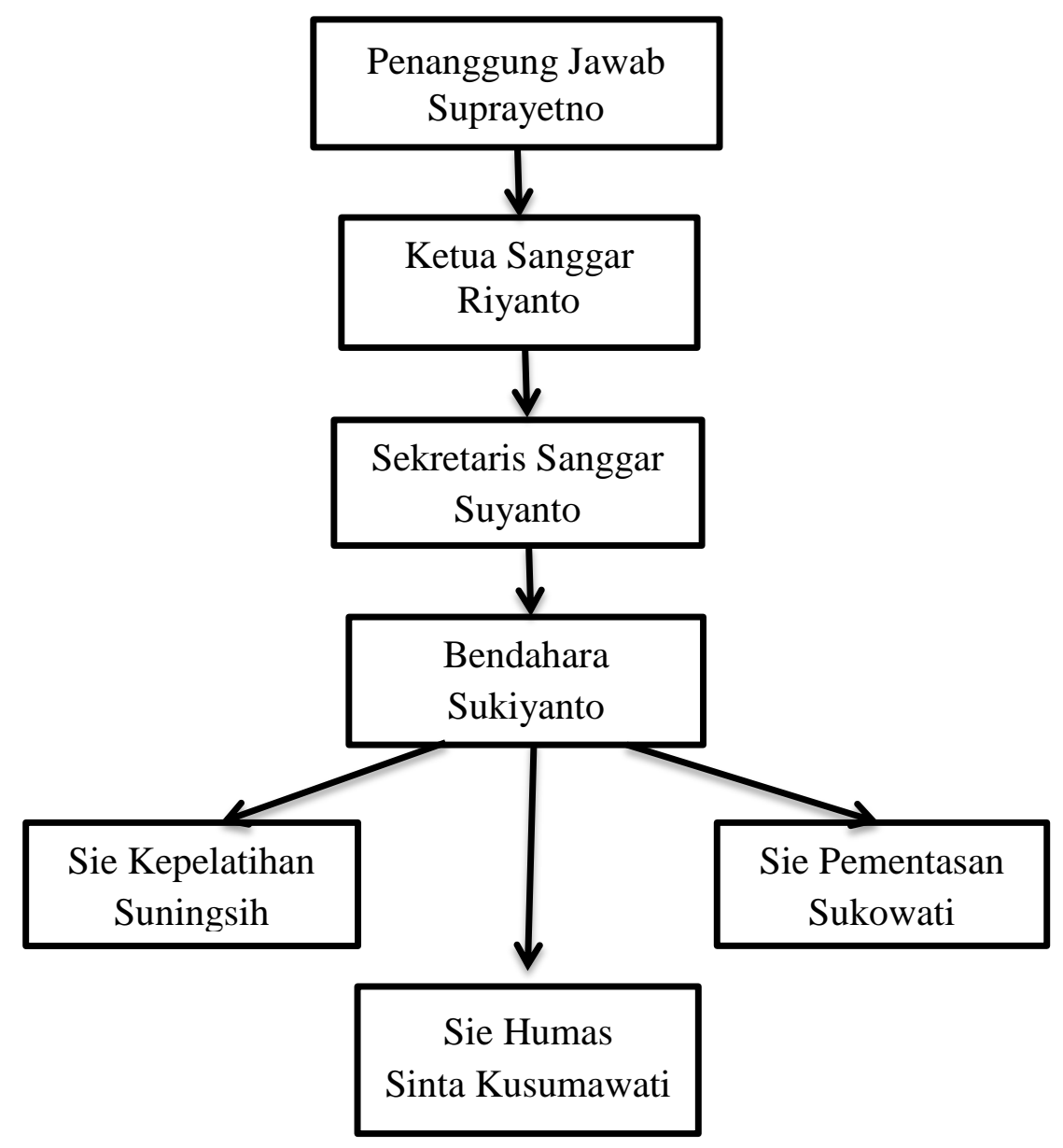

Sumber : Sanggar Putra Budaya, 17 April 2017

Bagan 4.1 merupakan struktur organisasi Sanggar Putra Budaya Desa Proyonanggan Kabupaten Batang yang terdiri dari Penanggung Jawab Sanggar Putra 
Budaya yaitu Bapak Suprayetno, lalu Ketua Sanggar Putra Budaya yaitu Bapak Riyanto, Sekretaris Sanggar Putra Budaya yaitu Bapak Suyanto, Bendahara Sanggar Putra Budaya yaitu Bapak Sukiyanto, Sie Kepelatihan Sanggar Putra Budaya yaitu Ibu Suningsih, Sie Pementasan Sanggar Putra Budaya yaitu Ibu Sukowati dan Sie Humas Sanggar Putra Budaya Desa Proyonanggan Kabupaten Batang yaitu Ibu Sinta Kusumawati.

Adapun penanggung jawab Sanggar Putra Budaya di Desa Proyonanggan Kabupaten Batang dipegang oleh Bapak Suprayetno. Dimana dahulunya Bapak Suprayetno merupakan ketua Sanggar Putra Budaya yang sekarang digantikan oleh Bapak Riyanto, Penanggungjawab Sanggar Putra Budaya yaitu Bapak Suprayetno merupakan tokoh yang mendukung berdirinya kembali Kesenian Babalu dan salah satu tokoh yang sangat berperan dalam usaha pelestarian Kesenian Babalu di Kabupaten Batang. Kemudian untuk Jabatan Ketua Sanggar Putra Budaya dipegang oleh Bapak Riyanto, Ketua Sanggar Putra Budaya mempunyai peran dalam mengatur kegiatan-kegiatan yang diadakan oleh Sanggar Putra Budaya ataupun kegiatan-kegiatan luar yang berkaitan dengan Sanggar Putra Budaya, selain itu Bapak Riyanto selaku ketua sanggar juga berperan dalam menginformasikan perkembangan Sanggar Putra Budaya kepada Pemerintah Pusat Kabupaten Batang.

Tugas sekretaris Sanggar Putra Budaya yaitu mencatat hasil rapat lalu mencatat data siswa yang mengikuti kegiatan sanggar serta menyusun kebutuhan Sanggar Putra Budaya. Tugas Bendahara Sanggar yaitu mencatat, mengelola dan menyimpan dana yang masuk kedalam keuangan Sanggar maupun hal lain yang berkaitan dengan kebutuhan Sanggar Putra Budaya. 


\subsubsection{Administrasi Sanggar Putra Budaya Desa Proyonanggan Kabupaten}

\section{Batang}

Administrasi Sanggar Putra Budaya Desa Proyonanggan Kabupaten Batang mempunyai data siswa sekitar 38 orang yang terdiri dari laki-laki dan perempuan dari berbagai umur yang berbeda. Siswa Sanggar Putra Budaya mempunyai tugas bertanggung jawab terhadap dirinya sendiri dalam menangkap materi yang telah diberikan oleh pelatih di Sanggar Putra Budaya Desa Proyonanggan Kabupaten Batang. Syarat menjadi anggota siswa dalam Pelatihan tari di Sanggar Putra Budaya Desa Proyonanggan Kabupaten Batang mempunyai beberapa ketentuan diantaranya yaitu : pria atau wanita berusia sekitar 5 - 40 tahun dengan mengisi identitas diri lalu membayar biaya pendaftaran siswa baru sebesar 20.000 serta membayar iuran bulanan pelatihan Sanggar Putra Budaya Desa Proyonanggan Kabupaten Batang dengan biaya sebesar 40.000.

Bedasarkan data siswa yang terdapat di Sanggar Putra Budaya Desa Proyonanggan Kabupaten Batang menunjukan bahwa jumlah siswa di Sanggar Putra Budaya Desa Proyonanggan Kabupaten Batang berjumlah 38 siswa yang terdiri oleh laki-laki dan perempuan pada periode tahun 2014-2017 dengan kondisi umur yang berbeda-beda. Berikut Tabel 4.4 merupakan data nama siswa Sanggar Putra Budaya Desa Proyonanggan Kabupaten Batang dengan jumlah siswa yaitu 38 siswa yang mengikuti pelatihan tari di Sanggar Putra Budaya Desa Proyonanggan Kabupaten Batang. 
Tabel 4.4

Data Siswa Tari Sanggar Putra Budaya Periode 2014-2017

\begin{tabular}{|c|c|c|c|}
\hline No & Nama Siswa & Usia & Tahun Masuk \\
\hline 1. & Rara Lestiani & 8 tahun & 2017 \\
\hline 2. & Linda & 10 tahun & 2016 \\
\hline 3. & Ganis Arfiana & 9 tahun & 2016 \\
\hline 4. & Zahra & 8 tahun & 2017 \\
\hline 5. & Dhenia tiara & 7 tahun & 2017 \\
\hline 6. & Karimah & 10 tahun & 2015 \\
\hline 7. & Prista & 9 tahun & 2016 \\
\hline 8. & Ayu k & 10 tahun & 2015 \\
\hline 9. & Rania & 10 tahun & 2015 \\
\hline 10. & Yesika & 10 tahun & 2015 \\
\hline 11. & Wendah & 11 tahun & 2016 \\
\hline 12. & Listyowati & 9 tahun & 2016 \\
\hline 13. & Marini k & 12 tahun & 2014 \\
\hline 14. & Desy Ayu & 10 tahun & 2016 \\
\hline 15. & Rissa & 11 tahun & 2016 \\
\hline 16. & Menik & 10 tahun & 2016 \\
\hline 17. & Ratu M & 11 tahun & 2015 \\
\hline 18. & Maya Destia & 12 tahun & 2015 \\
\hline 19. & Kurnia & 13 tahun & 2014 \\
\hline 20. & Magfiroh & 9 tahun & 2016 \\
\hline 21. & Puspitasari & 12 tahun & 2015 \\
\hline 22. & Rohma & 11 tahun & 2015 \\
\hline 23. & Dita Ayu & 10 tahun & 2015 \\
\hline 24. & Ardiana & 13 tahun & 2014 \\
\hline 25. & Lidya & 14 tahun & 2014 \\
\hline 26. & Safatul & 9 tahun & 2016 \\
\hline 27. & Mustika & 10 tahun & 2017 \\
\hline 28. & Diyah Ayu & 13 tahun & 2014 \\
\hline 29. & Karina dwi & 10 tahun & 2016 \\
\hline 30. & Amel & 12 tahun & 2017 \\
\hline 31. & Ridha & 12 tahun & 2014 \\
\hline 32. & Miftah & 11 tahun & 2017 \\
\hline 33. & Liza & 12 tahun & 2015 \\
\hline 34. & Isni Dian & 13 tahun & 2015 \\
\hline 35. & Nita & 10 tahun & 2017 \\
\hline 36. & Nur Khasanah & 13 tahun & 2015 \\
\hline 37. & Elsa Ayu & 14 tahun & 2014 \\
\hline 38. & Vella & 15 tahun & 2014 \\
\hline
\end{tabular}

Sumber : Data administrasi Siswa Sanggar Putra Budaya 2014-2017 
Pada tabel 4.4 merupakan data siswa tari di Sanggar Putra Budaya Kabupaten Batang periode 2014-2017. Adapun data yang diperoleh Sanggar Putra Budaya Desa Proyonanggan Kabupaten Batang yang berumur 8 tahun berjumlah 2 anak, lalu umur 9 tahun berjumlah 5 anak, umur 10 tahun berjumlah 11 anak, umur 11 tahun berjumlah 5 anak, umur 12 tahun berjumlah 6 anak, umur 13 tahun berjumlah 5 anak dan umur 14 tahun berjumlah 2 anak. Jadi total seluruh siswa di Sanggar Putra Budaya yaitu 38 orang anak.

\subsubsection{Progam Sanggar Putra Budaya Desa Proyonanggan Kabupaten Batang}

Program-program Sanggar Putra Budaya Desa Proyonanggan Kabupaten Batang antara lain yaitu program kerja tahunan dan program mingguan. Progam kerja merupakan suatu kegiatan rutin yang di susun oleh sanggar sebagai bentuk kerja yang dilaksanakan sesuai ketentuan waktu yang diberlakukan. Program kerja mingguan adalah program kerja yang rutin dilaksanakan tiap minggunya dalam pelaksanaan kepengurusan Sanggar Putra Budaya Desa Proyonanggan Kabupaten Batang. Program kerja tahunan adalah program kerja yang rutin dilaksanakan tiap tahun sekali oleh Sanggar Putra Budaya, yaitu Evaluasi Tari, dan Pementasan Kesenian Babalu.

Progam kerja mingguan berupa progam kegiatan latihan rutin Kesenian Babalu yang dilaksanakan seminggu sekali setiap hari Minggu jam 09:00 sampai jam 11:00 di Sanggar Putra Budaya Desa Proyonanggan Kabupaten Batang. Jadi dalam waktu satu bulan kegiatan pelatihan Kesenian Babalu didapatkan oleh siswa kurang lebih 3 sampai 4 kali pertemuan. 
Kesenian Babalu dalam pelatihannya di Sanggar Putra Budaya dipimpin oleh Ibu Suningsih selaku guru dan juga pelatih Kesenian Babalu. Kegiatan pelatihan tari di Sanggar Putra Budaya dimulai pukul 09:00 yang diawali dengan pelatihan Kesenian Babalu sebagai materi wajib lalu disusul dengan materi tari lain atau materi inti seperti Tari Molek, Tari Kukilo, Tari Bondan, Tari Merak dan Tari Kelinci. Berikut yaitu dokumentasi kegiatan pelatihan Kesenian Babalu di Sanggar Putra Budaya yang dilaksanakan pada hari Minggu pukul 09:00 pagi sampai 11:00.

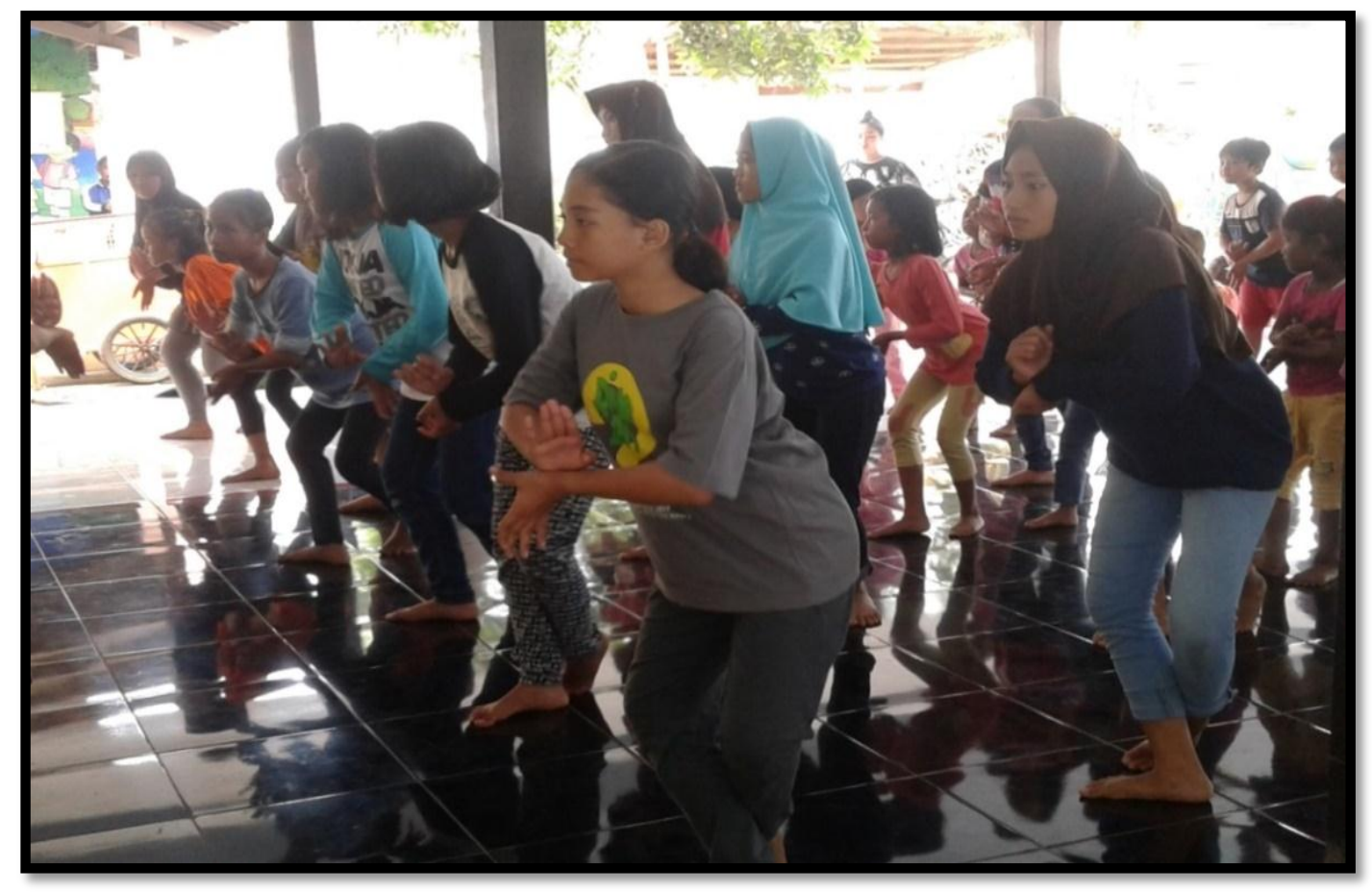

Foto 4.5 Pelatihan Kesenian Babalu Sumber: Adilah Endarini, 2 April 2017

Pada foto 4.5 merupakan kegiatan pelatihan tari dalam Kesenian Babalu di Sanggar Putra Budaya Desa Proyonanggan Kabupaten Batang, siswa terdiri dari berbagai macam golongan umur mulai dari anak-anak sampai dewasa. Dalam 
pelatihan tari siswa belajar dengan mengikuti gerakan yang diberikan oleh pelatih dan menghafalkannya lalu dipraktekkan.

\subsubsection{Sarana dan Prasarana Sanggar Putra Budaya Desa Proyonanggan Kabupaten Batang.}

Sarana dan Prasarana Sanggar Putra Budaya Desa Proyonanggan Kabupaten Batang terdiri dari tempat latihan, kostum tari dan speaker. Gedung pelatihan tari Sanggar Putra Budaya berada di Pendopo Kelurahan Desa Proyonanggan Kabupaten Batang sedangkan untuk penempatan kostum tari Sanggar Putra Budaya berada di rumah Ibu Sukimto tepatnya di depan Pendopo Kelurahan Desa Proyonanggan yang dijadikan sebagai tempat pelatihan tari. Berikut foto 4.6 merupakan lokasi kegiatan pelatihan Kesenian Babalu di Sanggar Putra Budaya Desa Proyonanggan Kabupaten Batang.

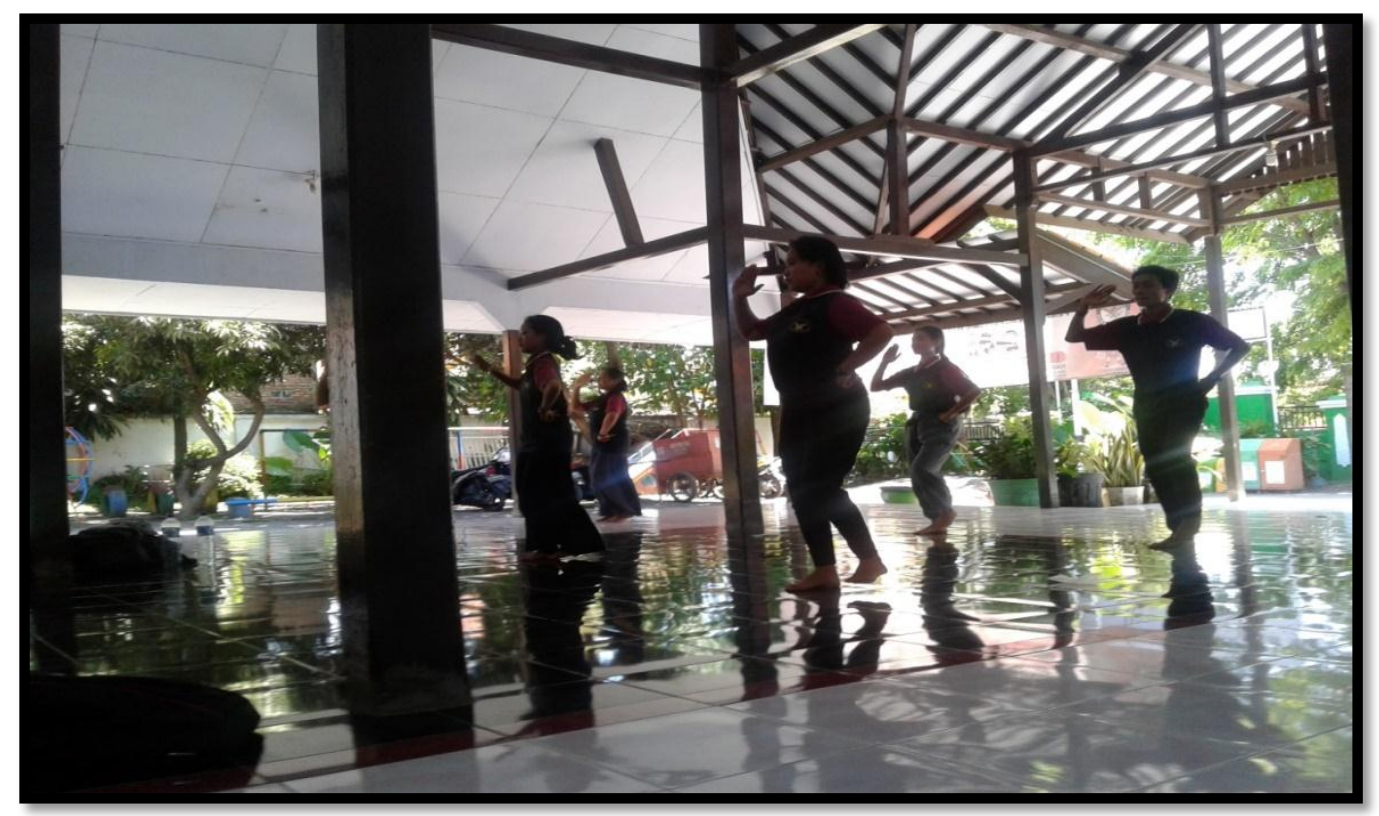

Foto 4.6 Pendopo Kelurahan Desa Proyonanggan

Sumber: Adilah Endarini, 18 September 2016 
Pada Foto 4.6 merupakan area tempat pelatihan Kesenian Sanggar Putra Budaya yang berada di Pendopo Kelurahan Desa Proyonanggan. Letak Sanggar sangat strategis karena berada di pinggir jalan raya lalu dekat dengan SD Proyonanggan 06 serta dekat dengan Puskesmas Kabupaten Batang. Sanggar Putra Budaya mendapat dukungan yang baik oleh Kepala Desa Proyonanggan Tengah, sehingga dalam proses pelatihan tari dapat berjalan dengan lancar tanpa suatu halangan. Pendopo Kelurahan Desa Proyonanggan juga dipakai untuk acara-acara lain yang berkaitan dengan kegiatan desa tanpa mengganggu jadwal latihan Sanggar Putra Budaya yang diadakan setiap hari Minggu pukul 09:00 sampai pukul 11:00.

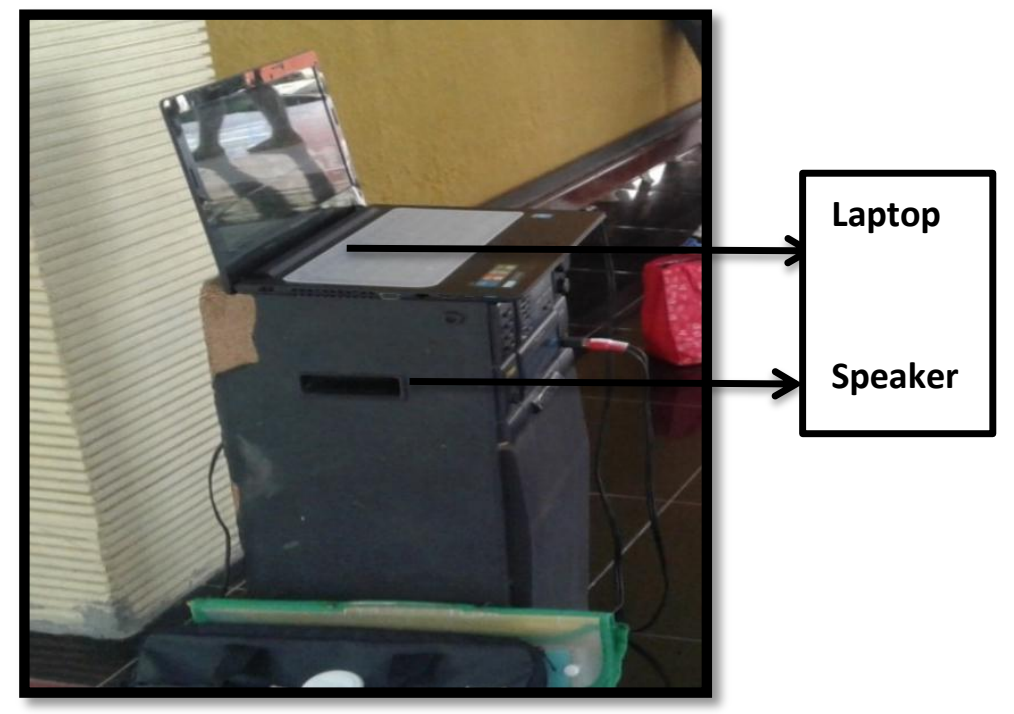

Foto 4.7 Laptop dan Speaker Sanggar Putra Budaya Sumber: Adilah Endarini, 18 September 2016

Foto 4.7 merupakan Laptop dan Speaker yang digunakan untuk menunjang dalam kegiatan pelatihan tari di Sanggar Putra Budaya. Dengan bantuan speaker, suara musik tari dapat terdengar lebih keras dan jelas oleh seluruh siswa dalam 
pelatihan tari di Sanggar Putra Budaya. Adapun perlengkapan yang digunakan untuk keperluan sanggar selain laptop dan speaker yaitu kostum. $\quad$ Berikut foto $\quad 4.8$ merupakan koleksi Kostum Sanggar Putra Budaya Desa Proyonanggan Kabupaten Batang.

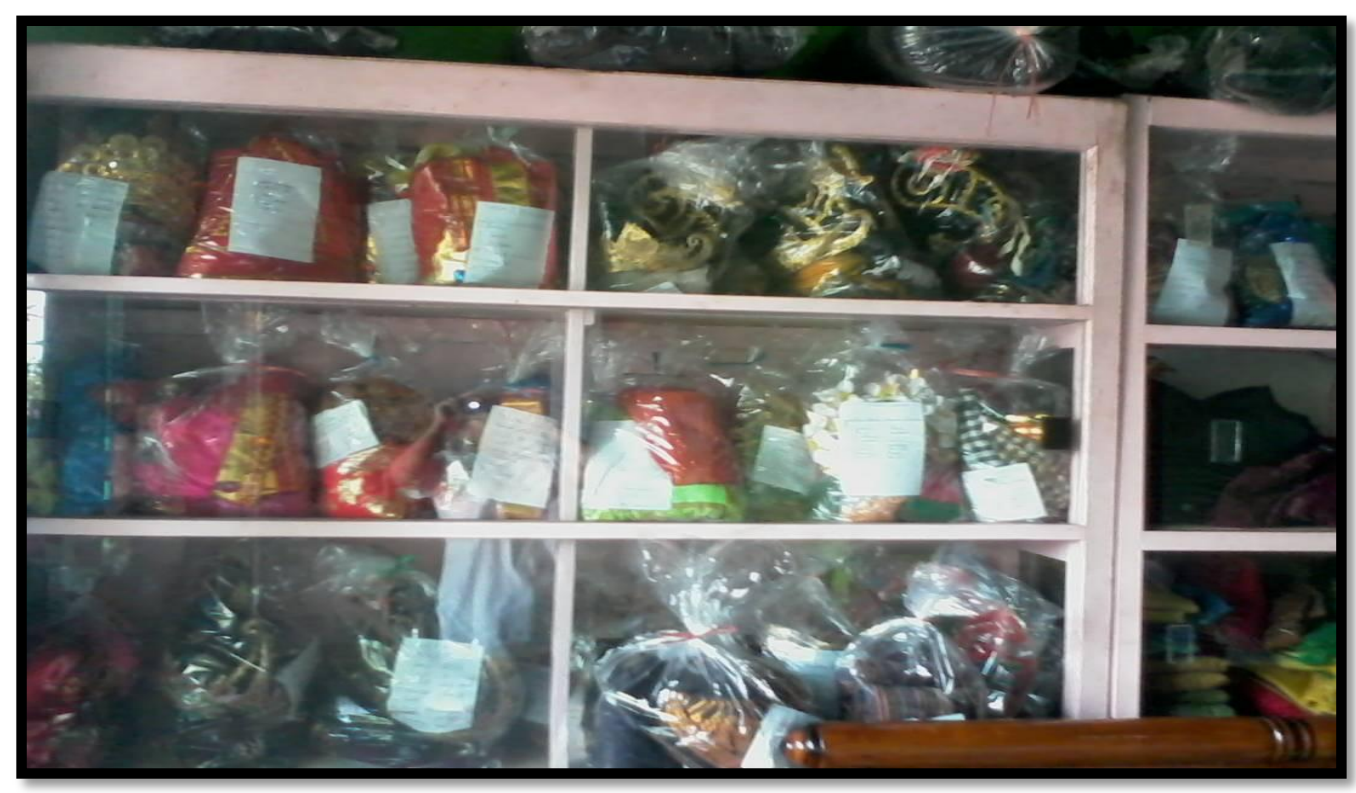

Foto 4.8 Koleksi Kostum Sanggar Putra Budaya

Sumber: Adilah Endarini, 12 Maret 2017

Pada Foto 4.8 merupakan Koleksi Kostum Sanggar Putra Budaya Desa

Proyonanggan Kabupaten Batang yang tersimpan rapi di dalam tempat etalase dan bertempat di rumah Ibu Soekimto di depan Kelurahan Desa Proyonanggan Kabupaten Batang. Kostum masing-masing tarian dikemas secara terpisah sesuai dengan kebutuhan dan dimasukan kedalam plastik. Namun tidak semua kostum dikemas satu kedalam plastik, ada yang ditata rapi di dalam ruangan tanpa dibungkus plastik seperti kain jarik, kebaya dan aksesoris (Wawancara Suningsih, 12 Maret 2017). 
Berikut Tabel 4.5 Koleksi Kostum di Sanggar Putra Budaya Desa Proyonanggan Kabupaten Batang yang terdiri dari 13 kostum tari dengan jumlah kostum total yaitu 330 stel. Kostum yang paling banyak yang dimiliki oleh Sanggar Putra Budaya Desa Proyonanggan Kabupaten Batang yaitu Kostum Tari Babalu, Kostum Tari Wira Pratiwi, Kostum Tari Sintren, dan Kostum Tari Kelinci.

Tabel 4.5 Data Koleksi Kostum Sanggar Putra Budaya tahun 2017

\begin{tabular}{|c|c|c|c|}
\hline No & Nama Barang & Jumlah & Kondisi \\
\hline 1. & Kostum Tari Babalu & $100 \mathrm{stel}$ & Terawat \\
2. & Kostum Tari Bondan & $20 \mathrm{stel}$ & Terawat \\
3. & Kostum Tari Wira Pratiwi & $30 \mathrm{stel}$ & Terawat \\
4. & Kostum Tari Sintren & $30 \mathrm{stel}$ & Terawat \\
5. & Kostum Tari Golek Manis & $20 \mathrm{stel}$ & Terawat \\
6. & Kostum Tari Kelinci & $30 \mathrm{stel}$ & Terawat \\
7. & Kostum Tari Golek Sulung & $10 \mathrm{stel}$ & Terawat \\
8. & Kostum Tari Yapong & $20 \mathrm{stel}$ & Terawat \\
9. & Kostum Tari Sri Rejeki & $20 \mathrm{stel}$ & Terawat \\
10. & Kostum Tari Bedhaya & $15 \mathrm{stel}$ & Terawat \\
11. & Kostum Tari Kijang & $5 \mathrm{stel}$ & Terawat \\
12. & Kostum Tari Kukilo & $14 \mathrm{stel}$ & Terawat \\
13. & Kostum Tari Kupu-kupu & $16 \mathrm{stel}$ & Terawat \\
\hline
\end{tabular}

Sumber : Wawancara Suningsih, 12 Maret 2017

Pada tabel 4.5 merupakan koleksi kostum Sanggar Putra Budaya Desa Proyonanggan Kabupaten Batang yang terdiri dari 13 kostum tari diantaranya yaitu Kostum Tari Babalu, Tari Bondan, Tari Wira Pertiwi, Tari Sintren, Tari Golek Manis, Tari Kelinci, Tari Golek Sulung, Tari Yapong, Tari Golek Sri Rejeki, Tari Kijang, Tari Kukilo, dan Tari Kupu-kupu. Koleksi Kostum yang paling banyak dipakai di Sanggar Putra Budaya Desa Proyonanggan Kabupaten Batang adalah Kostum Tari Babalu dengan jumlah kostum sebanyak 100 stel. Hal ini menunjukan bahwa masyarakat sedikit demi sedikit mulai menikmati kesenian Babalu baik 
melalui pementasan maupun melalui usaha-usaha lain yang berguna dalam usaha pelestarian Kesenian Babalu.

\subsection{Sejarah Kesenian Babalu di Sanggar Putra Budaya Desa Proyonanggan Kabupaten Batang}

Kesenian Babalu merupakan kesenian yang telah ada semenjak tahun 1940 sebelum negara Indonesia merdeka. Kesenian Babalu dikelola oleh Sanggar Putra Budaya yang diketuai oleh Bapak Riyanto, selain itu peran Bapak Suprayetno selaku penanggung jawab Sanggar dan Ibu Suningsih selaku pelatih sanggar juga sangat membantu dalam upaya melestarikan Kesenian Babalu. Bapak Suprayetno dan ibu Suningsih tidak hanya sebagai pengelola dan pelatih Sanggar namun juga ikut menjadi pemain dalam Kesenian Babalu. Bapak Suprayetno selain menjadi penanggungjawab sanggar juga menjadi pemusik serta merangkap vokal lalu Ibu Suningsih selain menjadi pelatih kadang juga merangkap menjadi penari ketika pertunjukan Kesenian Babalu dipertunjukan.

Kesenian Babalu awalmulanya dilestarikan oleh salah satu tokoh masyarakat yang ada di Desa Proyonanggan yaitu bernama Bapak Sukimto, beliau merupakan Ayah dari Bapak Suprayetno dan juga menjadi tokoh pertama pendiri Sanggar Putra Budaya, namun beliau telah wafat dan Kesenian Babalu dilestarikan secara turun-temurun oleh Bapak Suprayetno melalui Sanggar Putra Budaya. Perkembangan Kesenian Babalu di Sanggar Putra Budaya Desa Proyonanggan Kabupaten Batang dimulai sejak tahun 2000 oleh anggota Sanggar Putra Budaya dan para pecinta seni di Kabupaten Batang. 
Berikut merupakan hasil wawancara yang dilakukan oleh peneliti dengan Bapak Suprayetno selaku penanggung jawab sanggar, mantan ketua sanggar dan pelatih Kesenian Babalu pada tanggal 3 April 2017 yang mengatakan tentang sejarah sanggar sebagai berikut :

“....kesenian Babalu telah ada sejak jaman dahulu mbak, sejak bapak saya soekimto masih hidup pada masa penjajahan, namun kesenian babalu pernah mengalami kevakuman cukup lama juga setelah masa penjajahan, sehingga pada tahun 2000 saya dan teman-teman seniman batang menghidupkan kembali kesenian Babalu dan mengemasnya menjadi lebih baik lagi tanpa mengubah kekhasan yang sudah ada...”.

Awal mulanya muncul ide untuk menggali kembali Kesenian Babalu di Kabupaten Batang karena Kesenian Babalu memiliki latar belakang sejarah yang bagus yaitu berawal dari sebuah pertunjukan Teater Jawa lalu menjadi pertunjukan rutin bahkan menjadi kebutuhan masyarakat pada jaman dahulu untuk berdiskusi mencari siasat yang tepat untuk melawan penjajah. Kode-kode tertentu yang terdapat dalam Kesenian Babalu mempunyai arti bahwa penjajah akan datang dari sebelah Barat, sebelah Timur, sebelah Utara ataupun sebelah Selatan sehingga masyarakat Kabupaten Batang dapat mempersiapkan diri mencari siasat perang sebelum para penjajah datang dan memaksa masyarakat untuk kerja rodi.

Kesenian Babalu di Kabupaten Batang pada tahun 2000 sampai tahun 2017 terus mengalami perkembangan. Perkembangan tersebut dapat dilihat dari segi personil, gerak, dan iringan yang semakin inovatif. Perkembangan inilah yang membuat Kesenian Babalu di Kabupaten Batang tetap lestari di tengah munculnya kesenian-kesenian modern yang semakin banyak (Wawancara Suningsih 2 April 2017). 
Kesenian Babalu mempunyai anggota kurang lebih sekitar 20 pemain dengan durasi kurang lebih 10 menit yang terdiri dari penari dan pemusik, jumlah pemusik Kesenian Babalu sekitar 10 orang dan penari Kesenian Babalu biasanya sekitar 8-10 anak namun jumlah penari Kesenian Babalu tidak dibatasi karena semakin banyaknya penari akan semakin terlihat lebih bagus dalam pertunjukannya. Kesenian Babalu tergolong kesenian tradisional kerakyatan yang dahulunya merupakan jenis tarian tunggal berupa ketoprak jawa, namun sekarang kesenian Babalu terlihat lebih bagus ketika ditampilkan secara beramai-ramai.

Kesenian Babalu menggunakan kaoskaki dan kupluk berkucir yang menunjukan ciri khas dari kabupaten Batang yang mayoritas masyarakatnya beragama Islam dan berada di wilayah Pantura. Kesenian Babalu sering dipentaskan untuk memperingati acara-acara penting salah satunya seperti memperingati HUT Kemerdekaan RI, Hari jadi Kabupaten Batang, Upacara Penyambutan, Khitanan, Kliwonan, dan Hajatan.

Kesenian Babalu merupakan kesenian tradisional dari Kabupaten Batang yang dikembangkan dan dilestarikan di Sanggar Putra Budaya Desa Proyonanggan Kabupaten Batang tepatnya di Pendopo Kelurahan Desa Proyonanggan Kabupaten Batang. Kesenian Babalu di Sanggar Putra Budaya menggambarkan semangat para pejuang asal Batang dalam merebut kembali Kabupaten Batang dari kekuasaan para penjajah dengan suatu gerakan tari yang telah disepakati bersama oleh para pejuang untuk mengelabuhi para penjajah di wilayah Kabupaten Batang. 


\title{
4.4 Bentuk Pertunjukan Kesenian Babalu di Sanggar Putra Budaya Desa Proyonanggan Kabupaten Batang
}

\author{
Bentuk pertunjukan Kesenian Babalu di Sanggar Putra Budaya Desa \\ Proyonanggan Kabupaten Batang dipertunjukan atau ditampilkan dari awal \\ pementasan sampai akhir pementasan kepada penonton. Bentuk pertunjukan \\ kesenian Babalu didalamnya mengandung unsur-unsur nilai keindahan yang \\ disampaikan oleh pencipta Kesenian Babalu kepada penikmat kesenian.
}

Pencipta dalam arti yaitu Sanggar Putra Budaya dan penikmat yaitu Penonton Kesenian Babalu. Hal tersebut sesuai bedasarkan hasil yang diperoleh dengan teori Jazuli tahun 2001 yang digunakan, bahwa bentuk adalah suatu struktur yang menunjuk pada sistem atau pengucapan, yang didalamnya terkandung faktorfaktor yang kait-mengkait dan saling bergantung satu dengan yang lainnya dalam mewujudkan satu kesatuan yang utuh.

Bedasarkan teori Jazuli tahun 1994 dengan hasil yang diperoleh peneliti, maka bentuk pertunjukan Kesenian Babalu secara keseluruhan memerlukan suatu elemen penyajian tari yang berfungsi untuk mengungkapkan ekspresi jiwa manusia yang di komunikasikan lewat gerak yang memiliki nilai estetis apabila didalamnya terdapat elemen-elemen penyajian tari secara terpadu. Bentuk pertunjukan tari pada kesenian Babalu dimunculkan melalui elemen dasar tari dan elemen pendukung tari sesuai dengan pendapat Jazuli, yakni bentuk tari dapat dilihat dari elemen dasar tari dan elemen pendukung tari. Elemen dasar tari terdiri dari gerak, ruang, dan waktu. Elemen pendukung tari terdiri dari pelaku, gerak, iringan (musik), tata rias, tata 
busana, tata suara, tempat pertunjukan, waktu penyelenggaraan, properti dan penonton.

\subsubsection{Elemen Dasar dalam Kesenian Babalu}

Elemen dasar tari mengandung elemen gerak, ruang, dan waktu. Begitu juga dengan Tari dalam Kesenian Babalu di Sanggar Putra Budaya Desa Proyonanggan Kabupaten Batang. Kesenian Babalu di Sanggar Putra Budaya Desa Proyonanggan Kabupaten Batang memiliki elemen dasar yang terdiri dari gerak, ruang, dan waktu sesuai dengan pendapat Jazuli yaitu sebagai berikut :

\subsubsection{Gerak}

Gerak dalam suatu tarian muncul disebabkan dengan adanya tenaga yang menggerakkan, dan tubuh manusia yang dijadikan sebagai alat untuk digerakkan. Gerak berdasarkan jenisnya terbagi menjadi dua, yakni gerak maknawi dan gerak murni. Gerak dalam Kesenian Babalu di Sanggar Putra Budaya Desa Proyonanggan yang dianalisis dengan pendapat dari Jazuli mengenai gerak dalam tari. Gerak yang diciptakan dalam Kesenian Babalu sebagian besar termasuk jenis gerak maknawi.

Gerak dalam Kesenian Babalu menunjukan simbol atau tingkah laku suatu peristiwa kehidupan manusia pada jaman penjajahan, hal tersebut berhubungan dengan sesama manusia, lingkungan, dan politik. Perwujudan pertunjukan Kesenian Babalu dilakukan melalui gerakan-gerakan seorang prajurit yang enerjik disertai dengan gerakan beladiri atau silat. Adapun bentuk pertunjukan Kesenian Babalu diwujudkan melalui ragam gerak yang terbagi menjadi tiga gugus gerak, yakni awal, inti, dan akhir. 
Pada awal pementasan para penari dan pengiring kesenian Babalu bersiapsiap di sebelah panggung ataupun di belakang panggung, kemudian para pemusik memasuki panggung dan mulai duduk memegang alat musik bagiannya masingmasing. Suatu bunyi peluit yang dikomando oleh salah satu penari merupakan bagian awal pementasan kesenian Babalu lalu disusul dengan bunyi rebana dan slogan Kabupaten Batang yaitu lagu Babalu Mbatang yang disertai dengan gerakan jalan ditempat. Kemudian pada bagian inti disusul dengan ragam gerak Langkah Tepuk, Sembah Berjalan, Ukel duduk, Silat, Doublestep, Tepuk Gejhug, Toleh Kanan Kiri.

Gerakan dalam kesenian Babalu di Sanggar Putra Budaya Kabupaten Batang sangat lincah dan penuh kekuatan karena menunjukan seorang prajurit wanita yang bersemangat dalam mengatur siasat perang melawan penjajah. Kemudian pada bagian akhir pertunjukan yaitu dimulai dari ragam gerak Bapangan, Lambeyan, dan Dolanan Asto, kemudian ketika penari meninggalkan panggung dengan ragam gerak jalan ditempat akhirnya telah menunjukan bahwa berakhirnya suatu pertunjukan Kesenian Babalu.

Gerakan dalam Kesenian Babalu terlihat sederhana namun penuh kekuatan yang ditunjukan pada ragam gerakan silat. Gerak dalam kesenian Babalu juga menggambarkan semangat para pejuang dalam merebut kembali kemerdekaan Kabupaten Batang melalui gerakan-gerakan keprajuritan yang penuh semangat, enerjik dan luwes. Kode peluit dalam pementasan Kesenian Babalu dimainkan oleh salah satu penari yang berperan sebagai pemimpin 
untuk mengawali suatu gerakan agar kompak dan saling bekerjasama dalam mengatur siasat perang.

Gerak dalam Kesenian Babalu meliputi ragam gerak selain itu juga terdapat unsur-unsur gerak yang berasal dari dalam anggota tubuh manusia. Tubuh manusia terbagi menjadi empat yaitu kepala, badan, tangan dan kaki. Masingmasing mempunyai gerak tersendiri yang berdiri sebagai unsur. Sedang unsurunsur yang dimaksud adalah sebagai berikut : Unsur gerak kepala, unsur gerak badan, unsur gerak tangan dan unsur gerak kaki. Berikut merupakan Ragam gerak dalam Kesenian Babalu di Sanggar Putra Budaya Desa Proyonanggan Kabupaten Batang.

\subsubsection{Ragam Gerak}

Bentuk ragam gerak tari dalam Kesenian Babalu di Sanggar Putra Budaya Desa Proyonanggan Kabupaten Batang sangat sederhana namun tetap tertata rapi, melainkan penampilan keluwesan dan sikap penari yang penuh semangat serta enerjik menunjukan jiwa keprajuritan meskipun ditarikan oleh seorang wanita. Gerakan dalam kesenian Babalu yang enerjik disertai bunyi peluit dari penari menjadikan perhatian utama oleh para penonton.

Ragam Gerak dalam Kesenian Babalu di Sanggar Putra Budaya Desa Proyonanggan Kabupaten Batang di bagi dalam beberapa nama ragam diantaranya yaitu Ragam Jalan di tempat, Langkah Tepuk, Sembah Berjalan, Ukel duduk, Silat, Doublestep, Tepuk Gejhug, Toleh Kanan Kiri, Sendi, Bapangan, Lambeyan, dan Dolanan Asto. Penggarapan bentuk gerak tari oleh 
pencipta tari mempunyai ciri dan rasa tersendiri karena kemampuan dari masing-masing pencipta tari berbeda-beda.

Di dalam gerak tari selalu didasari oleh daya kreativitas sang pencipta ataupun pelatih tari namun di dalam gerak Kesenian Babalu di Sanggar Putra Budaya Desa Proyonanggan Kabupaten Batang belum terlalu di bakukan semuanya, hal ini dikarenakan gerak dalam Kesenian Babalu di Sanggar Putra Budaya Desa Proyonanggan Kabupaten Batang masih mengalami perkembangan namun tetap mempertahankan ciri khas gerak tradisi jaman dahulu, selain itu gerakan dalam Kesenian Babalu di Sanggar Putra Budaya juga bisa dikurangi atau ditambah dalam ragam geraknya hal ini dikarenakan oleh permintaan dari penanggap suatu kesenian yang berbeda-beda. (Wawancara Suningsih, 2 April 2017).

Berikut Tabel 4.4 merupakan penjelasan ragam gerak dalam Kesenian Babalu di Sanggar Putra Budaya Desa Proyonanggan Kabupaten Batang yang terdiri dari beberapa nama ragam gerak diantaranya yaitu ragam gerak jalan di tempat, ragam gerak langkah tepuk, ragam gerak sembah berjalan, ragam gerak ukel duduk, ragam gerak silat, ragam gerak doublestep, ragam gerak tepuk gejhug, ragam gerak toleh kanan kiri, sendi, bapangan, lambeyan, dan dolanan asto serta uraian ragam gerak untuk mempermudah pembaca dalam memahami nam a ragam-ragam gerak yang terdapat dalam kesenian Babalu yang berasal dari Sanggar Putra Budaya Desa Proyonanggan Kabupaten Batang : 
Tabel 4.6 Ragam Gerak Kesenian Babalu

Sumber : Wawancara Suningsih 2 April 2017

\begin{tabular}{|c|c|c|c|}
\hline No & $\begin{array}{l}\text { Nama } \\
\text { Ragam }\end{array}$ & Uraian Gerak & Keterangan \\
\hline 1. & $\begin{array}{l}\text { Jalan di } \\
\text { tempat }\end{array}$ & 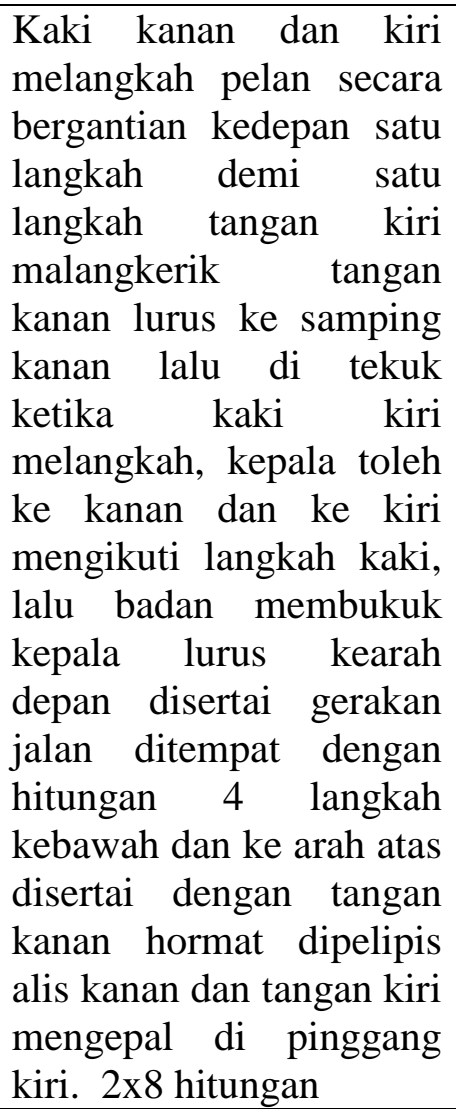 & $\begin{array}{c}\text { Foto 4.9 Ragam Jalan ditempat } \\
\text { Sumber: Adilah Endarini, } 12 \\
\text { Maret } 2017\end{array}$ \\
\hline 2. & $\begin{array}{l}\text { Langkah } \\
\text { Tepuk }\end{array}$ & $\begin{array}{l}\text { Posisi badan kearah } \\
\text { samping lalu kedua kaki } \\
\text { dilangkahkan kedepan } \\
\text { dan kebelakang } \\
\text { mengikuti gerakan kedua } \\
\text { tangan yang ditepuk } \\
\text { disamping kuping kanan } \\
\text { dan telinga kiri disertai } \\
\text { kepala menengok kearah } \\
\text { depan belakang Gera kan } \\
\text { kaki dan tangan secara } \\
\text { bersamaan yaitu ketika } \\
\text { tangan ditepukkan } \\
\text { disamping telinga, kaki } \\
\text { dilangkahkan kedepan } \\
\text { dan kebelakang namun } \\
\text { posisi badan tetap kearah }\end{array}$ & $\begin{array}{c}\text { Foto 4.10 Ragam Langkah } \\
\text { Tepuk }\end{array}$ \\
\hline
\end{tabular}




\begin{tabular}{|c|c|c|c|}
\hline & & samping kanan. & $\begin{array}{c}\text { Sumber: Adilah Endarini, } 12 \\
\text { Maret } 2017 \\
\end{array}$ \\
\hline \multirow[t]{2}{*}{3.} & \multirow[t]{2}{*}{$\begin{array}{l}\text { Sembah } \\
\text { berjalan }\end{array}$} & \multirow[t]{2}{*}{$\begin{array}{l}\text { Kedua tangan dengan } \\
\text { posisi menyembah } \\
\text { kearah depan lalu kaki } \\
\text { kanan berada didepan } \\
\text { dan kaki kiri berada } \\
\text { dibelakang. Setelah itu } \\
\text { kaki dirapatkan sejajar } \\
\text { dan jalan ditempat sambil } \\
\text { tangan digerak-gerakkan } \\
\text { kearah depan mengikuti } \\
\text { langkah kedua kaki. } \\
\text { Posisi kepala } \\
\text { dianggukkan kedepan } \\
\text { mengikuti langkah kedua } \\
\text { kaki. 2x8 hitungan. }\end{array}$} & \\
\hline & & & $\begin{array}{l}\text { Foto } 4.11 \text { Ragam Sembah } \\
\text { berjalan } \\
\text { Sumber: Adilah Endarini, } 12 \\
\text { Maret } 2017\end{array}$ \\
\hline 4. & $\begin{array}{l}\text { Ukel } \\
\text { duduk }\end{array}$ & $\begin{array}{l}\text { Kedua tangan terlentang } \\
\text { ke arah samping kanan } \\
\text { dan kiri lalu pergelangan } \\
\text { tangan dan jari tangan } \\
\text { diukel diikuti gerakan } \\
\text { pinggang yang } \\
\text { digoyangkan kekanan } \\
\text { dan kekiri. setelah itu } \\
\text { gerakan dilakukan } \\
\text { dengan posisi badan } \\
\text { duduk. Kemudian kedua } \\
\text { tangan dibawa kearah } \\
\text { belakang secara } \\
\text { bergantian diikuti dengan } \\
\text { gerakan kepala yang } \\
\text { tengok kearah belakang } \\
\text { secara bergantian. Posisi } \\
\text { badan ndegek sambil } \\
\text { duduk dan di ayunkan } \\
\text { mengikuti gerak tangan } \\
\text { ke samping kanan dan } \\
\text { kiri. kedua tangan } \\
\text { diarahkan didepan dada } \\
\text { dan digerakkan sedikit }\end{array}$ & $\begin{array}{c}\text { Foto 4.12 Ragam Ukel Duduk } \\
\text { Sumber: Adilah Endarini, } 12 \\
\text { Maret } 2017\end{array}$ \\
\hline
\end{tabular}




\begin{tabular}{|c|c|c|c|}
\hline & & $\begin{array}{l}\text { keatas secara bergantian } \\
\text { dengan posisi badan yang } \\
\text { pelan-pelan berdiri. }\end{array}$ & \\
\hline 5. & Silat & $\begin{array}{l}\text { Tangan kanan ditekuk } \\
\text { siku-siku menghadap } \\
\text { keatas dan tangan kiri } \\
\text { ditekuk siku-siku } \\
\text { menghadap kesamping } \\
\text { diikuti kaki kiri diangkat, } \\
\text { lalu gerakan tangkis } \\
\text { kesamping kanan dan } \\
\text { kesamping kiri secara } \\
\text { bergantian, tangan } \\
\text { dibuka lebar terlentang } \\
\text { kearah samping kanan } \\
\text { dan kiri lalu tangan kiri } \\
\text { dibawa ke arah belakang } \\
\text { kepala dan tangan kanan } \\
\text { kearah depan lurus, } \\
\text { kedua tangan di paha } \\
\text { sambil ditepuk dan } \\
\text { meloncat 3x. }\end{array}$ & $\begin{array}{c}\text { Foto } 4.13 \text { Ragam silat } \\
\text { Sumber: Adilah Endarini, } 12 \\
\text { Maret } 2017\end{array}$ \\
\hline 6 . & $\begin{array}{l}\text { Double } \\
\text { step }\end{array}$ & $\begin{array}{l}\text { Kaki kanan dilangkahkan } \\
\text { secara double step yaitu } \\
\text { kearah samping kanan } \\
\text { dua langkah dan kearah } \\
\text { samping kiri dua langkah } \\
\text { dilakukan secara cepat } \\
\text { disertai gerakan salah } \\
\text { satu tangan kanan dan } \\
\text { kiri lurus kedepan dan } \\
\text { dibelakang kepala secara } \\
\text { bergantian. Gerakan } \\
\text { kepala kearah depan dan } \\
\text { sedikit menoleh } \\
\text { mengikuti arah kaki. } \\
\text { Dilakukan dengan } \\
\text { hitungan } 1 x 8 \text { a }\end{array}$ & $\begin{array}{c}\text { Foto 4.14 Ragam Doublestep } \\
\text { Sumber: Adilah Endarini, } 12 \\
\text { Maret } 2017\end{array}$ \\
\hline
\end{tabular}




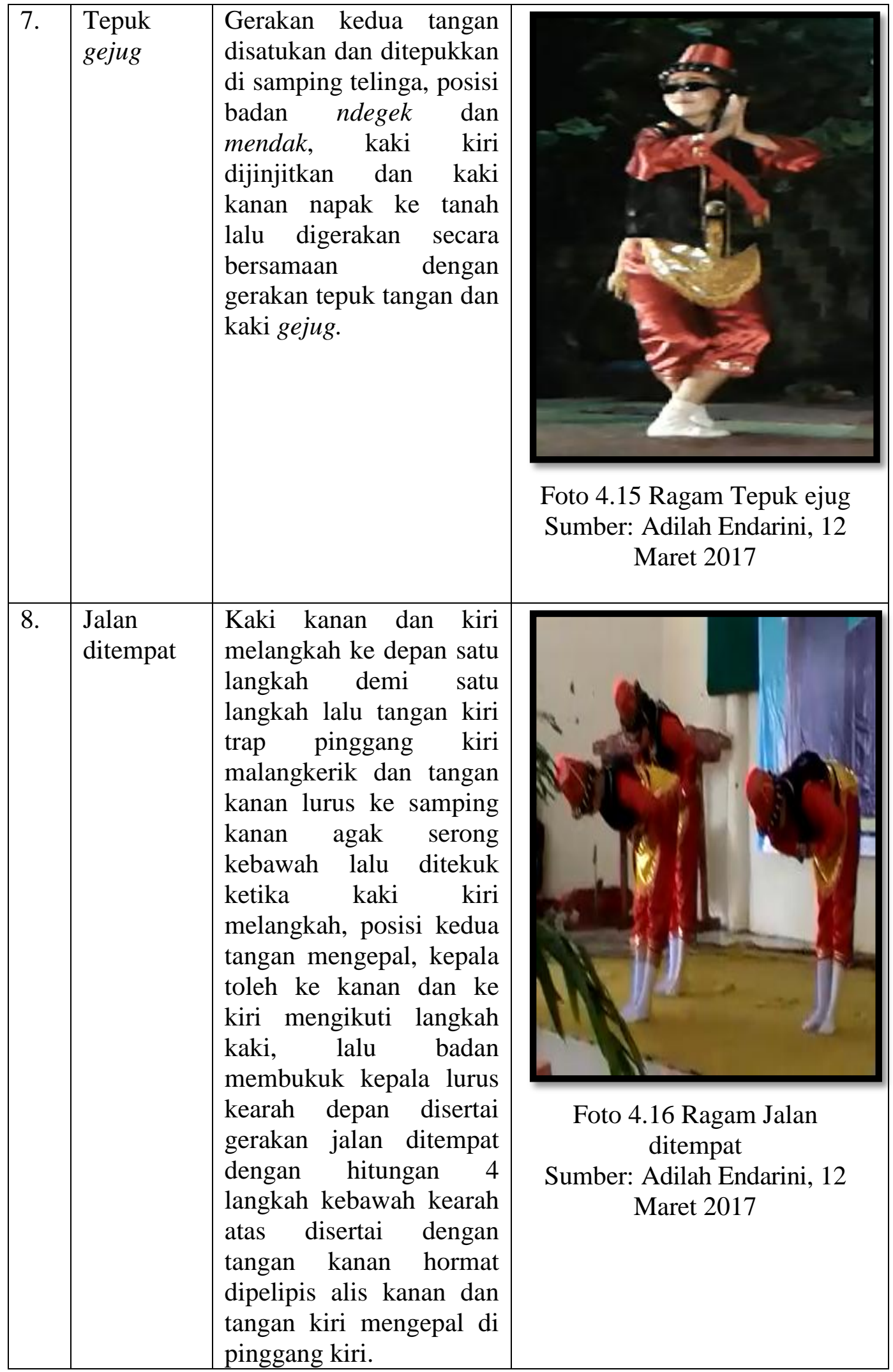




\begin{tabular}{|c|c|c|c|}
\hline 9. & $\begin{array}{l}\text { Toleh } \\
\text { Kanan } \\
\text { Kiri }\end{array}$ & $\begin{array}{l}\text { Posisi kaki kuda-kuda } \\
\text { dibuka lebar dan mendak } \\
\text { lalu kedua tangan } \\
\text { dipinggang dan kepala } \\
\text { ditoleh ke kanan dan ke } \\
\text { kiri, posisi badan ndegek } \\
\text { dan di ayunkan ke atas } \\
\text { dan kebawah mengikuti } \\
\text { gerakan } \\
\text { Dilakukan } \\
\text { hitungan } 2 \times 8\end{array}$ & $\begin{array}{l}\text { Foto 4.17 Ragam toleh kanan } \\
\text { kiri } \\
\text { Sumber: Adilah Endarini, } 12 \\
\text { Maret } 2017\end{array}$ \\
\hline 10. & Sendi & $\begin{array}{l}\text { Kedua tangan dibawa ke } \\
\text { samping kanan, tangan } \\
\text { kanan lurus kearah } \\
\text { samping kanan dan } \\
\text { tangan kiri ditekuk di } \\
\text { depan pusar, kepala } \\
\text { tengok ke arah tangan } \\
\text { kanan lalu jalan srisik } \\
\text { berputar, kemudian } \\
\text { kedua tangan disilangkan } \\
\text { didepan pusar sambil } \\
\text { diputar, bahu digerakan } \\
\text { secara bergantian. Posisi } \\
\text { badan ndegek dan kaki } \\
\text { silang, kanan di depan } \\
\text { dan kiri di belakang. } \\
\text { Dilakukan dengan } \\
\text { hitungan } 2 \times 8\end{array}$ & $\begin{array}{l}\text { Foto 4.18 Ragam Sendi } \\
\text { Sumber: Adilah Endarini, } 12 \\
\text { Maret 2017 }\end{array}$ \\
\hline 11. & Bapangan & $\begin{array}{l}\text { osisi badan mendak dan } \\
\text { ndegek lalu kedua kaki } \\
\text { mentang posisi kuda- } \\
\text { kuda. Kemudian tangan } \\
\text { digerakkan ke atas dan } \\
\text { kebawah dengan arah }\end{array}$ & \\
\hline
\end{tabular}




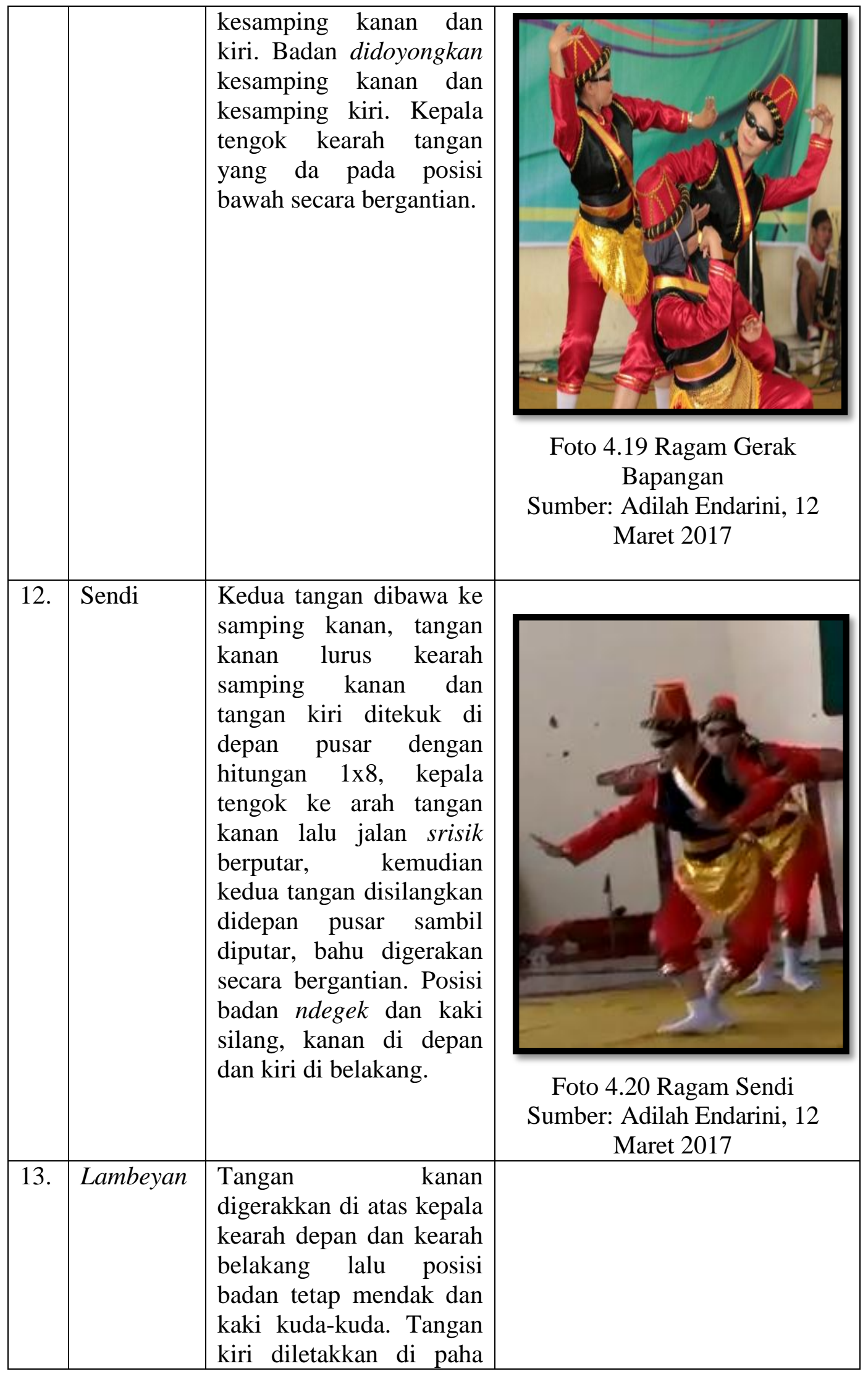




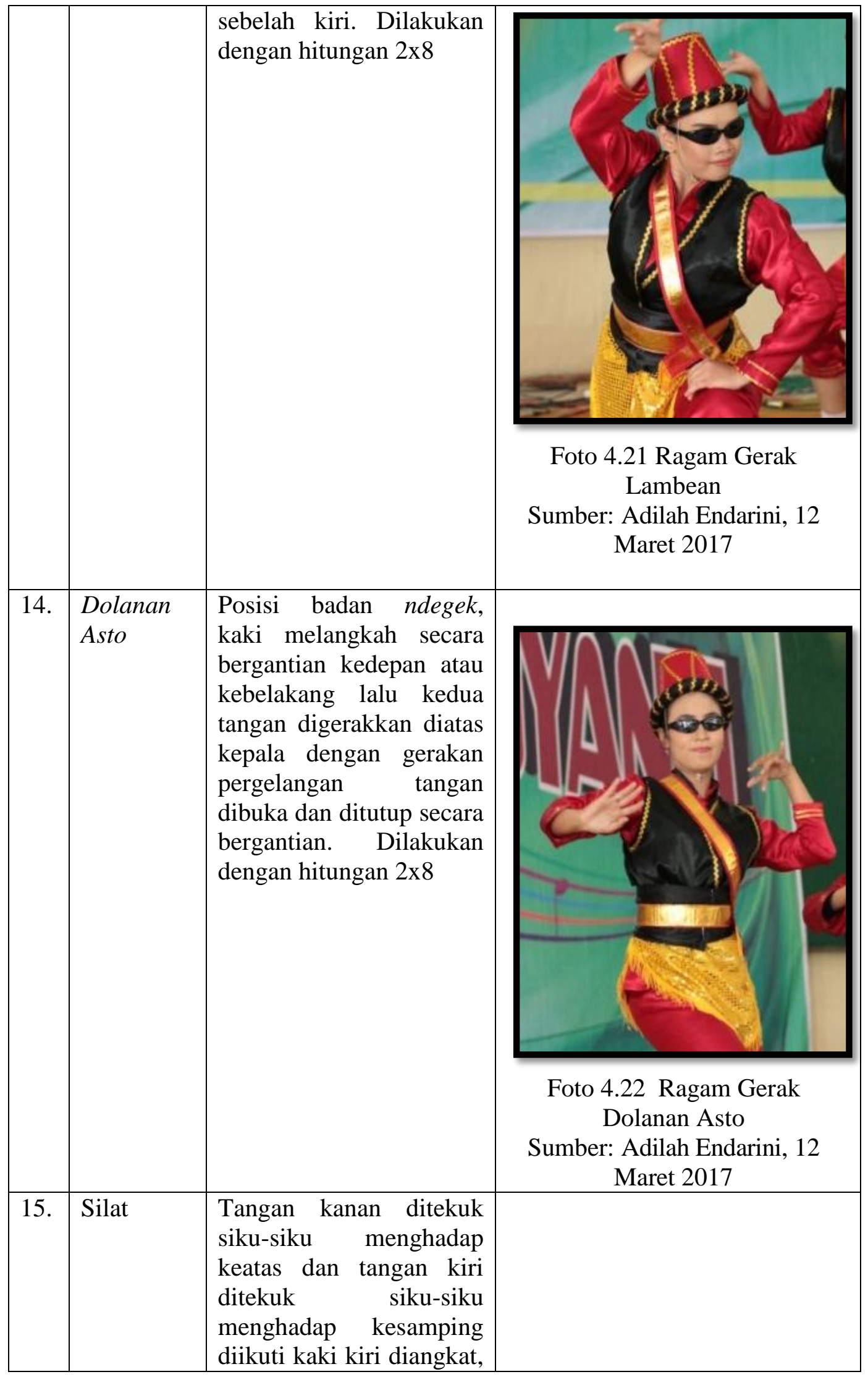




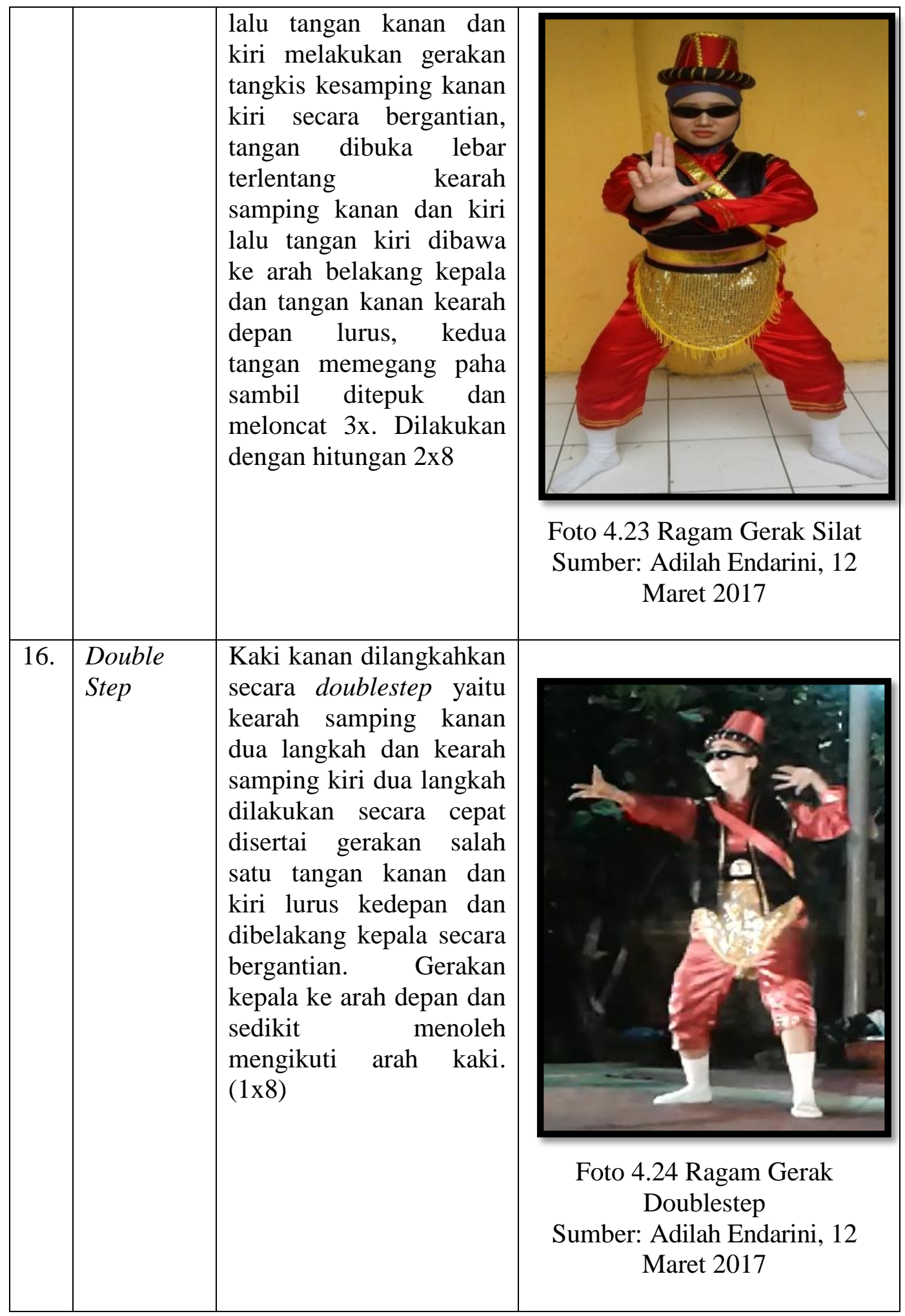




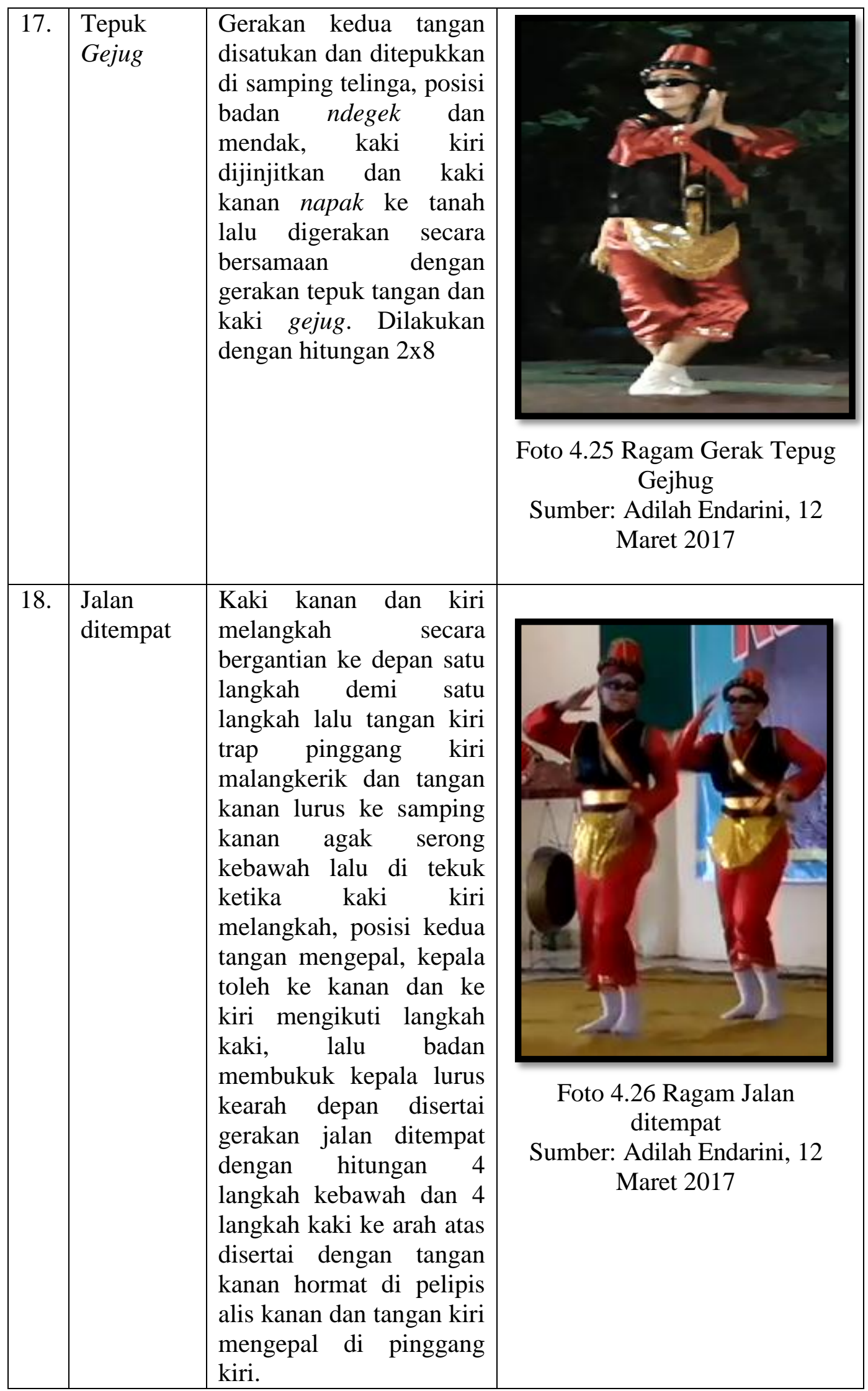




\subsubsection{Unsur Gerak Kesenian Babalu}

Unsur Gerak dalam Kesenian Babalu terdiri dari 4 unsur yaitu unsur kepala, unsur tangan, unsur badan dan unsur kaki. Pada Unsur kepala terdapat sikap Toklek kanan kiri dan Toleh, lalu nama gerak dalam unsur kepala yaitu Toleh Kanan kiri dan Pacak Gulu. Berikut penjelasan secara keseluruhan unsur-unsur dalam Kesenian Babalu di Sanggar Putra Budaya :

Tabel 4.7 Unsur Gerak Kepala

\begin{tabular}{|c|c|c|c|}
\hline No & Sikap & Nama Gerak & Deskripsi \\
\hline 1. & $\begin{array}{l}\text { Toklek kanan } \\
\text { kiri }\end{array}$ & & $\begin{array}{l}\text { Pandangan ke arah serong kanan dan } \\
\text { serong kiri, atau kepala di gerakkan } \\
\text { kearah serong kanan kiri dengan } \\
\text { pandangan agak kebawah lantai. }\end{array}$ \\
\hline 2. & & Toleh kanan kiri & $\begin{array}{l}\text { Menggerakkan kepala kesamping } \\
\text { kanan dan kiri }\end{array}$ \\
\hline 3. & Toleh & & $\begin{array}{l}\text { Pandangan dan sikap muka } \\
\text { menghadap kearah samping kanan } \\
\text { dan kiri secara bergantian }\end{array}$ \\
\hline 4. & & Pacak gulu & $\begin{array}{l}\text { Gerakan Kepala yang digerakkan } \\
\text { bersamaan dengan dagu. }\end{array}$ \\
\hline
\end{tabular}

Sumber: Wawancara Adilah Endarini, 12 Maret 2017

Setelah membahas tentang unsur gerak kepala, berikut tabel 4.8 merupakan pembahasan unsur gerak tangan yang terdapat dalam kesenian Babalu. Didalam unsur gerak tangan dibagi menjadi 10 unsur diantaranya yaitu Ngrayung, Ukel, Ngepel, Menthang Asto, Trap Cethik, Trap Puser, Malangkerik, Tangkis Sembah dan Tumpang Asto. 
Tabel 4.8 Unsur Gerak Tangan

\begin{tabular}{|c|c|c|c|}
\hline No & Sikap & Gerak & Deskripsi \\
\hline 1. & Ngrayung & & $\begin{array}{l}\text { Jari jempol dengan Ibu jari disatukan } \\
\text { sampai membentuk lingkaran oval } \\
\text { lalu keempat jari dirapatkan kearah } \\
\text { ibu jari. }\end{array}$ \\
\hline 2. & & Ukel & $\begin{array}{l}\text { Gerakan seluruh telapak tangan } \\
\text { sampai batas pergelangan tangan } \\
\text { lalu diputarkan } 360 \text { derajat dari arah } \\
\text { atau hadap langit kearah dalam dekat } \\
\text { urat nadi }\end{array}$ \\
\hline 3. & Ngepel & & Gerakan tangan menggenggam \\
\hline 4. & $\begin{array}{l}\text { Menthang Asto } \\
\text { depan belakang }\end{array}$ & & $\begin{array}{l}\text { Tangan kanan atau kiri lurus depan } \\
\text { belakang dengan sikap jari ngrayung }\end{array}$ \\
\hline 5. & $\begin{array}{l}\text { Trap cethik } \\
\text { kanan kiri }\end{array}$ & & $\begin{array}{l}\text { Menempatkan telapak tangan } \\
\text { kanan/kiri didepan cethik kanan/kiri }\end{array}$ \\
\hline 6. & Trap Puser & & $\begin{array}{l}\text { Posisi tangan kanan dan tangan kiri } \\
\text { tepat di depan pusar }\end{array}$ \\
\hline 7. & Malangkrik & & $\begin{array}{l}\text { Sikap tangan dan kedua tangan di } \\
\text { pinggang, posisi tangan kiri di } \\
\text { pinggang sebelah kiri lalu tangan } \\
\text { kanan di pinggang sebelah kanan. }\end{array}$ \\
\hline 8. & Tangkis & & $\begin{array}{l}\text { Gerakan tangan kanan memegang } \\
\text { pergelangan tangan kiri lalu tangan } \\
\text { kiri ditekuk kedepan }\end{array}$ \\
\hline 9. & Sembah & & $\begin{array}{l}\text { Kedua pergelangan tangan bertemu } \\
\text { dengan posisi tangan saling menyatu } \\
\text { lalu arah jari-jari menghadap kearah } \\
\text { atas. }\end{array}$ \\
\hline 10. & Tumpang Asto & & $\begin{array}{l}\text { Tangan kanan diatas tangan kiri } \\
\text { dipusar }\end{array}$ \\
\hline
\end{tabular}

Sumber: Wawancara Adilah Endarini, 12 Maret 2017 
Selanjutnya yaitu unsur gerak badan dalam Kesenian Babalu oleh Sanggar Putra Budaya Desa Proyonanggan Kabupaten Batang yang terdiri dari 5 unsur gerak badan yaitu Mayuk, Ndegek, Ogek Bahu, Leyek Kanan Kiri dan Membungkuk. Berikut Tabel 4.9 merupakan penjelasan unsur gerak badan dalam Kesenian Babalu :

Tabel 4.9 Unsur Gerak Badan

\begin{tabular}{|l|l|l|l|}
\hline No & Sikap & Nama Gerak & Deskripsi \\
\hline 1. & Mayuk & Ndegek & $\begin{array}{l}\text { Sikap dada dibusungkan kedepan } \\
\text { dan badan direbahkan kearah depan } \\
\text { lalu posisi badan mendhak }\end{array}$ \\
3. & Ogek bahu & $\begin{array}{l}\text { Posisi badan tegap dengan kondisi } \\
\text { dada di busungkan kedepan dengan } \\
\text { sikap badan lurus dan kuat }\end{array}$ \\
4. & Leyek kanan kiri & $\begin{array}{l}\text { Gerakan bahu digerakkan memutar } \\
\text { kedepan dan kebelakang lalu } \\
\text { menggoyangkan pinggul ke samping } \\
\text { kanan dan kiri }\end{array}$ \\
& Membungkuk & $\begin{array}{l}\text { Sikap badan } n d e g e g \text { dengan badan } \\
\text { direbahkan ke kanan atau ke kiri lalu } \\
\text { berat badan bertumpu di kaki } \\
\text { kanan/kiri }\end{array}$ \\
& & & $\begin{array}{l}\text { Sikap badan ditekuk 90 derajat } \\
\text { kearah bawah, badan berada pada } \\
\text { posisi seperti rukuk pada sholat. } \\
\text { Kedua tangan di tekuk siku-siku } \\
\text { kearah paha dan kepala menunduk } \\
\text { kearah bawah }\end{array}$ \\
\hline
\end{tabular}

Sumber: Wawancara Adilah Endarini, 12 Maret 2017 
Tabel 4.10 merupakan Unsur Gerak Kaki yang terdapat didalam Kesenian Babalu diantaranya yaitu Gejug Kanan Kiri, Jinjit, Doublestep, Kuda-kuda, Jalan ditempat, Napak Kanan kiri dan duduk simpuh.

Tabel 4.10 Unsur Gerak Kaki

\begin{tabular}{|c|c|c|c|}
\hline No & Sikap & Nama Gerak & Deskripsi \\
\hline 1. & Gejug kanan/kiri & & $\begin{array}{l}\text { Menghentakkan kaki kanan/kiri } \\
\text { dibelakang kaki kanan/kiri. }\end{array}$ \\
\hline 2. & & Jinjit & $\begin{array}{l}\text { Gerakan kaki diangkat keatas jari } \\
\text { kaki sebagai suatu tumpuan }\end{array}$ \\
\hline 3. & & Doublestep & $\begin{array}{l}\text { Gerakan kaki dilangkahkan secara } \\
\text { dua kali/double ke kanan, dan dua } \\
\text { kaki/double kekiri secara beraturan }\end{array}$ \\
\hline 4. & Kuda-kuda & & $\begin{array}{l}\text { Gerakan kaki mendak dengan } \\
\text { tumpuan kuat, posisi kaki serong ke } \\
\text { kanan dan kekiri }\end{array}$ \\
\hline 5. & & Jalan ditempat & $\begin{array}{l}\text { Gerakan kaki berjalan kecil-kecil } \\
\text { seperti srisik }\end{array}$ \\
\hline 6. & Napak kanan/kiri & & $\begin{array}{l}\text { Meletakkan telapak kaki kanan/kiri } \\
\text { dengan sikap telapak kaki kanan } \\
\text { atau kiri menyentuh lantai. }\end{array}$ \\
\hline 7. & Duduk Simpuh & & $\begin{array}{l}\text { Sikap duduk dengan siku menyentuh } \\
\text { lantai dan telapak kaki menyentuh } \\
\text { pantat. }\end{array}$ \\
\hline
\end{tabular}

Sumber: Wawancara Adilah Endarini, 12 Maret 2017

Bedasarkan deskripsi ragam gerak serta unsur-unsur gerak diatas seperti unsur gerak kepala, tangan, badan, dan kaki dapat disimpulkan bahwa penghubung gerak dalam Kesenian Babalu terdapat didalam ragam gerak jalan ditempat. Ragam gerak jalan ditempat merupakan perpaduan antara gerak tangan dan kaki untuk 
memulai ke gerakan yang selanjutnya. Jumlah ragam gerak dalam Kesenian Babalu yaitu 18 ragam, lalu untuk jumlah unsur kepala yaitu 4, unsur tangan yaitu 10, unsur badan yaitu 5 dan unsur kaki yaitu 7. Jadi jumlah keseluruhan unsur yaitu 26 unsur.

\subsubsection{Ruang}

Ruang dalam tari terbagi menjadi dua, yakni ruang yang diciptakan penari dan ruang pentas atau tempat penari melakukan gerak. Ruang dalam Kesenian Babalu dianalisis berdasarkan pendapat dari Jazuli. Ruang yang peneliti bahas pada Kesenian Babalu adalah ruang gerak penari dalam menari. Gerak tubuh penari sangat berpengaruh pada garis, volume, arah, level, arah hadap, dan fokus. Setiap ragam gerak dalam Kesenian Babalu memiliki garis, volume, arah hadap, dan fokus yang berbeda, namun tidak menutup kemungkinan pada ragam gerak tertentu memiliki kesamaan pada aspek ruang. Analisis ruang dalam Kesenian Babalu dapat dilihat pada rangkaian ragam gerak Jalan di tempat, Langkah Tepuk, Sembah Berjalan, Ukel duduk, Silat, Doublestep, Tepuk Gejhug, Toleh Kanan Kiri, Sendi, Bapangan, Lambeyan, dan Dolanan Asto.

\section{Jalan ditempat}

Garis yang dihasilkan para penari pada ragam gerak Jalan ditempat yaitu garis lurus. Volume yang dihasilkan para penari sempit. Arah gerak para penari dalam kesenian Babalu berjalan maju ke depan dari arah samping kanan, samping kiri dan tengah. Level yang dihasilkan para penari adalah level sedang. Arah hadap para penari Kesenian Babalu lurus ke depan. Fokus pandangan kedua penari lurus 
ke depan dan ketika berjalan arah pandangan mengikuti gerak tangan ke samping kanan dan ke samping kiri.

\section{Langkah Tepuk}

Garis yang dihasilkan oleh para penari Kesenian Babalu pada gerak langkah tepuk yaitu garis lurus. Volume yang dihasilkan oleh para penari kesenian Babalu lumayan lebar dengan arah gerak para penari berputar 360 derajat di tempat. Level yang dihasilkan oleh para penari kesenian Babalu yaitu level sedang. Arah hadap para penari kesenian Babalu menghadap ke depan, ke samping kanan, ke belakang, dan kesamping kiri dilakukan dengan gerakan kaki digejugkan.

\section{Sembah Berjalan}

Garis yang dihasilkan oleh para penari Kesenian Babalu pada gerak sembah berjalan yaitu garis lurus. Volume yang dihasilkan oleh para penari kesenian Babalu lumayan lebar dengan arah gerak para penari lurus berjalan kearah depan. Level yang dihasilkan oleh para penari kesenian Babalu yaitu level sedang. Arah hadap para penari kesenian Babalu menghadap ke depan dan ke belakang.

\section{Ukel duduk}

Garis yang dihasilkan oleh para penari Kesenian Babalu pada gerak Ukel duduk yaitu garis lengkung. Volume yang dihasilkan oleh para penari kesenian Babalu lebar dengan arah gerak para penari lurus berdiri lalu duduk kearah depan. Level yang dihasilkan oleh para penari kesenian Babalu yaitu level sedang. Arah hadap para penari kesenian Babalu menghadap ke depan. 


\section{Silat}

Garis yang dihasilkan oleh para penari Kesenian Babalu pada gerak silat yaitu garis lengkung dan garis lurus. Volume yang dihasilkan oleh para penari kesenian Babalu lebar dengan arah gerak para penari lurus berdiri lalu mengangkat satu kaki dan melompat kecil 3x lompatan kearah depan. Level yang dihasilkan

oleh para penari kesenian Babalu yaitu level sedang dan level tinggi. Arah hadap para penari kesenian Babalu pada ragam gerak silat yaitu menghadap kearah depan.

\section{Doublestep}

Garis yang dihasilkan oleh para penari Kesenian Babalu pada ragam gerak doublestep yaitu garis lengkung dan garis lurus. Volume yang dihasilkan oleh para penari kesenian Babalu lebar dengan arah gerak para penari lurus berdiri lalu berjalan secara cepat dua kali ke kanan dan dua kali ke kiri. Level yang dihasilkan oleh para penari kesenian Babalu yaitu level sedang. Arah hadap para penari kesenian Babalu menghadap ke depan.

\section{Tepuk Gejhug}

Garis yang dihasilkan oleh para penari Kesenian Babalu pada gerak tepuk gejhug yaitu garis lurus. Volume yang dihasilkan oleh para penari kesenian Babalu lumayan lebar dengan arah gerak para penari berputar 360 derajat di tempat. Level yang dihasilkan oleh para penari kesenian Babalu yaitu level sedang. Arah hadap para penari kesenian Babalu menghadap ke depan, ke samping kanan, ke belakang, dan kesamping kiri dilakukan dengan gerakan kaki digejugkan sambil berputar. 


\section{Toleh Kanan Kiri}

Garis yang dihasilkan oleh para penari Kesenian Babalu pada gerak Toleh Kanan Kiri yaitu garis lurus. Volume yang dihasilkan oleh para penari kesenian Babalu lumayan lebar dengan arah gerak para penari toleh kepala ke kanan dan toleh kekiri. Level yang dihasilkan oleh para penari kesenian Babalu yaitu level sedang. Arah hadap para penari kesenian Babalu menghadap ke arah depan, lalu dilakukan dengan gerakan kaki digejugkan sambil berputar

\section{Sendi}

Garis yang dihasilkan oleh para penari Kesenian Babalu pada ragam gerak sendi yaitu posisi Kaki Kanan samping kanan dan kaki Kiri garis lurus. Volume yang dihasilkan oleh para penari kesenian Babalu lumayan lebar dengan arah gerak para penari mayuk badannya kearah depan sambil pundak diputar ke arah belakang secara bergantian. Level yang dihasilkan oleh para penari kesenian Babalu yaitu level sedang. Arah hadap para penari pada ragam gerak sendi di kesenian Babalu menghadap ke arah depan

\section{Bapangan}

Garis yang dihasilkan oleh para penari Kesenian Babalu pada ragam gerak bapangan yaitu posisi Kaki Kanan samping kanan dan kaki Kiri mentang posisi kuda-kuda. Tenaga yang dikeluarkan cukup besar serta volume yang dihasilkan oleh para penari kesenian Babalu lumayan lebar dengan arah gerak para penari esamping kanan dan kiri ditempat secara bergantian. Level yang dihasilkan oleh para penari kesenian Babalu yaitu level sedang. Arah hadap para penari pada ragam gerak sendi di kesenian Babalu menghadap ke arah depan. 


\section{Lambeyan}

Garis yang dihasilkan oleh para penari Kesenian Babalu pada ragam gerak Lambeyan yaitu posisi Kaki Kanan samping kanan dan kaki Kiri mentang posisi kuda-kuda. Tenaga yang dikeluarkan cukup besar serta volume yang dihasilkan oleh para penari kesenian Babalu lumayan lebar dengan arah gerak para penari ke samping kanan, kiri, depan dan belakang. Level yang dihasilkan oleh para penari kesenian Babalu yaitu level sedang. Arah hadap para penari pada ragam gerak sendi di kesenian Babalu menghadap ke arah depan dan samping

\section{Dolanan Asto.}

Garis yang dihasilkan oleh para penari Kesenian Babalu pada ragam gerak dolanan asto yaitu garis lurus. Volume yang dihasilkan oleh para penari kesenian Babalu lumayan lebar dengan arah gerak para penari berjalan kearah depan dan kearah belakang. Level yang dihasilkan oleh para penari kesenian Babalu yaitu level sedang. Arah hadap para penari kesenian Babalu menghadap ke depan, dan ke belakang.

\subsubsection{Waktu}

Waktu dalam tari merupakan seberapa lama penari melakukan suatu gerakan. Waktu meliputi aspek tempo, ritme, durasi, dan irama. Waktu dalam Kesenian Babalu di Sanggar Putra Budaya dianalisis berdasarkan pendapat dari Jazuli. Analisis waktu dalam Kesenian Babalu meliputi tempo, ritme, durasi, dan irama. 


\subsection{Tempo}

Tempo dalam gerak tari merupakan kecepatan atau kelambatan sebuah gerak. Tempo gerak yang ada pada Kesenian Babalu dari hitungan lambat kecepat, karena dalam satu gerakan menggunakan 8 hitungan lambat pada gerakan ragam jalan ditempat, setelah ragam gerak double step gerakan mulai bertempo lebih cepat sehingga gerak yang dikeluarkan oleh penari Babalu lebih enerjik.

\subsection{Ritme}

Ritme dalam gerak tari merupakan pola perulangan yang teratur dari kumpulan-kumpulan bagian gerak yang berbeda kecepatannya. Ritme gerak yang ada pada Kesenian Babalu cenderung bervariasi dilihat dari ragam gerak, ada yang cepat dan lambat.

\subsection{Durasi}

Durasi dalam gerak Kesenian Babalu adalah jangka waktu ketika Kesenian itu berlangsung. Durasi pada Kesenian Babalu yang digunakan untuk bergerak yaitu dimulai dari datangnya penari Kesenian Babalu ke dalam panggung lalu membunyikan peluit, dan diakhiri dengan berjalannya penari kesenian Babalu keluar dari panggung selama kurang lebih 10 menit.

\subsubsection{Elemen Pendukung Kesenian Babalu di Sanggar Putra Budaya}

Elemen pendukung Kesenian Babalu di Sanggar Putra Budaya Desa Proyonanggan Kabupaten Batang dianalisis berdasarkan pendapat Jazuli, yang terdiri dari pelaku, musik, tata rias, tata busana, tata suara, tempat pementasan, 
waktu pementasan dan penonton. Berikut merupakan pembahasan elemen-elemen pendukung dalam Kesenian Babalu

\subsubsection{Pelaku}

Pelaku merupakan seseorang yang terlibat langsung dalam suatu pertunjukan atau pementasan. Pelaku dalam Kesenian Babalu di Sanggar Putra Budaya dibagi dalam tiga peran yakni pemusik, penari, dan vocal. Pada awal pertunjukan posisi penari Kesenian Babalu dan vocal berada di samping para pemusik Kesenian Babalu. Jumlah pemusik dalam Kesenian Babalu sekitar 7-10 orang yang alat musiknya terdiri dari Kendhang, Kempul, Kenong, Bonang, Rebana dan Gong. Vocal dalam Kesenian Babalu berjumlah 2-4 orang namun hal ini juga bisa bertambah ataupun berkurang sesuai dengan permintaan dari penanggap Kesenian Babalu. Jumlah penari Kesenian Babalu sekitar 5-10 orang penari, namun jika semakin banyak penari dan ditarikan secara massal maka Kesenian Babalu akan terlihat lebih bagus.

Peran pelaku dalam perkembangan Kesenian Babalu di Sanggar Putra Budaya maupun di kalangan masyarakat Kabupaten Batang sangat penting, Bapak Suprayertno merupakan salah satu tokoh yang mempunyai peran besar dalam usaha melestarikan Keberadaan Kesenian Babalu di Kabupaten Batang. Berikut foto 4.27 merupakan dokumentasi berupa foto yang diambil oleh peneliti saat berwawancara dengan Bapak Suprayetno selaku pengelola dan penanggungjawab Sanggar Putra Budaya pada tanggal 3 April 2017 di Kantor DPRD Kabupaten Batang. 


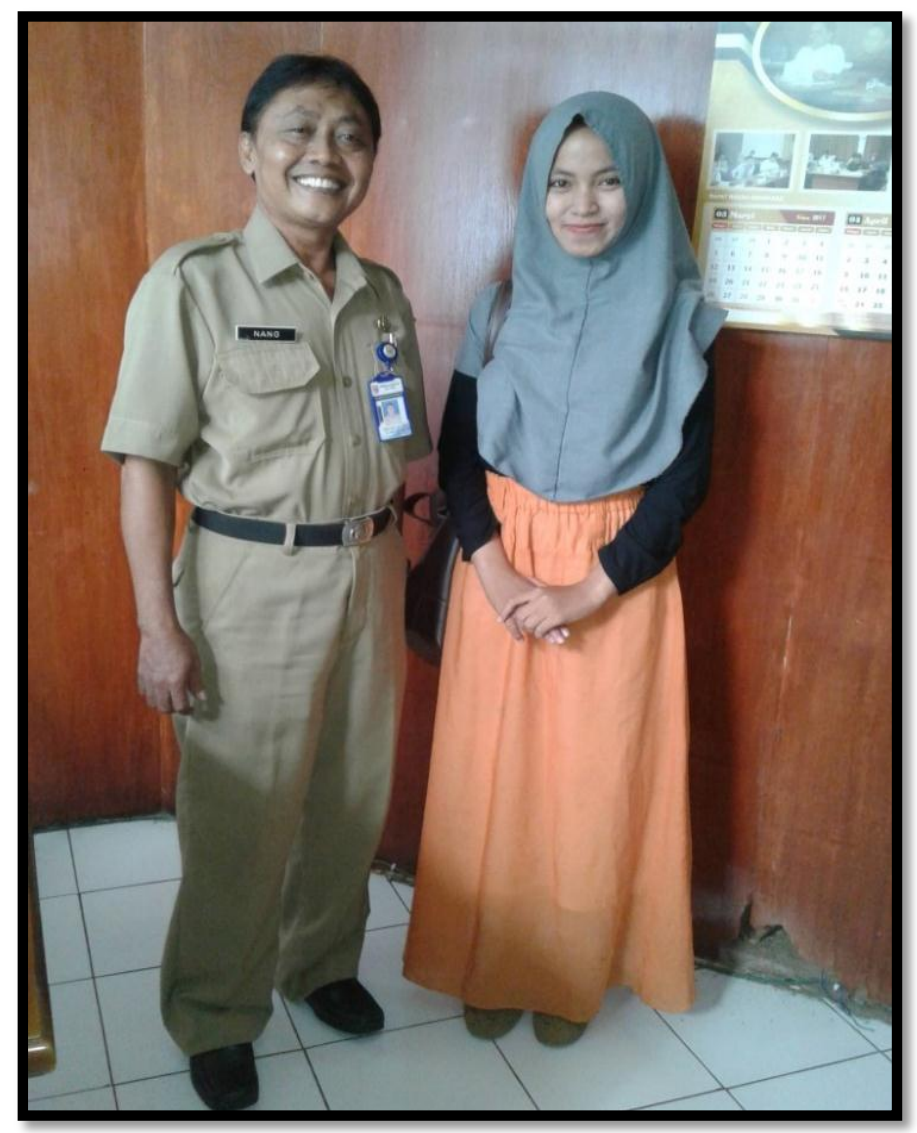

Foto 4.27 Penanggungjawab Sanggar Putra Budaya Sumber: Adilah Endarini, 18 September 2016

Pada foto 4.27 merupakan penanggungjawab Sanggar Putra Budaya yang bernama Bapak Suprayetno, beliau dahulu juga merupakan pemusik Kesenian Babalu serta ketua di Sanggar Putra Budaya sebelum digantikan oleh Bapak Riyanto. Bapak Suprayetno merupakan seseorang yang mempunyai latarbelakang kesenian yang bagus. Selain itu Bapak Suprayetno juga bekerjasama dengan salah satu seorang penari yaitu Ibu Suningsih.

Ibu Suningsih merupakan seorang guru yang mempunyai peran yang sangat besar dalam melestarikan Kesenian Babalu. Berikut dokumentasi berupa foto yang 
peneliti peroleh saat Ibu Suningsih mementaskan Kesenian Babalu. Seperti pada Foto 4.28 berikut.

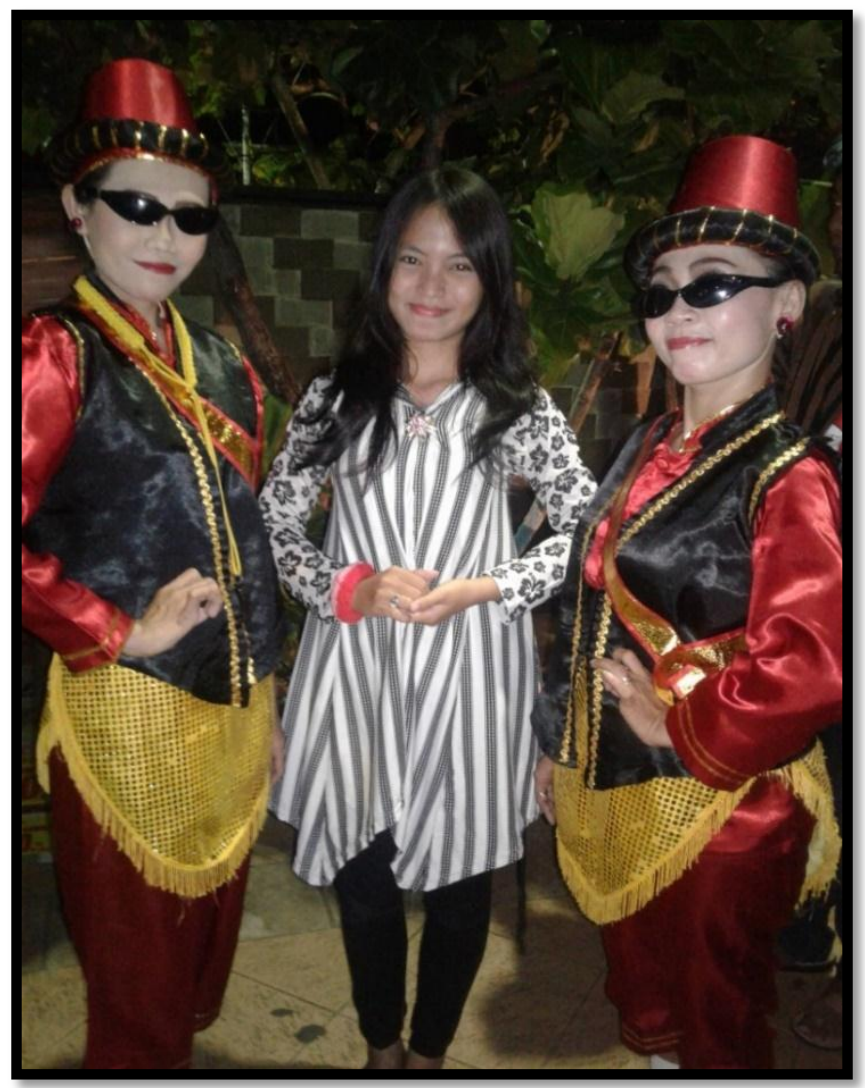

Foto 4.28 Pelatih Tari Sanggar Putra Budaya Sumber: Adilah Endarini, 18 September 2016

Foto 4.28 merupakan pelatih kesenian Babalu dan juga sebagai penari Kesenian Babalu di Sanggar Putra Budaya Desa Proyonanggan Kabupaten Batang, setelah mementaskan kesenian Babalu di Jalan Veteran Alun-alun Kabupaten Batang pada tanggal 30 september 2016. Ibu Suningsih merupakan pelatih Sanggar Putra Budaya dan selalu mengisi kegiatan pelatihan tari di Sanggar Putra Budaya Desa Proyonanggan Kabupaten Batang pada hari Minggu jam 09.00-11.00. 


\subsubsection{Musik/Iringan}

Iringan musik yang terdapat dalam Kesenian Babalu di Kabupaten Batang menggunakan gamelan Jawa dengan laras Pelog yang terdiri dari Kendhang, Kentongan, Rebana, Kenong, Kempul Bonang, dan Gong. Kesenian Babalu di Sanggar Putra Budaya Desa Proyonanggan Kabupaten Batang menggunakan vokal dengan tembang yang berjudul Babalu Mbatang dan Ilir-ilir. Menurut Suprayetno (Wawancara 3 April 2017) mengatakan bahwa iringan musik dan lirik lagu Babalu Mbatang mempunyai arti sejarah bahwa Kesenian Babalu pada jaman dahulu digunakan sebagai media komunikasi antar warga dalam mengatur siasat perang dan untuk berdiskusi dalam melawan penjajah.

Musik atau iringan dalam Kesenian Babalu di Sanggar Putra Budaya Kabupaten Batang seiring berjalannya waktu telah mengalami perkembangan jika dibandingkan dengan jaman dahulu, perkembangan iringan musik dalam kesenian Babalu yaitu pada penambahan alat musik gamelan seperti demung, saron, perkusi dan memberi variasi musik dengan menggunakan kendang Jaipong. Bunyi peluit juga merupakan suatu iringan yang dijadikan sebagai tanda dalam pertunjukannya. Berikut merupakan dokumentasi berupa foto pemusik dan alat musik yang digunakan dalam pertunjukan Kesenian Babalu oleh Sanggar Putra Budaya pada tanggal 30 Agustus 2016. Pertunjukan Kesenian Babalu dilaksanakan pada acara rutin yang di selenggarakan oleh Dinas Kesenian Daerah Kabupaten Batang. Pertunjukan Kesenian rutin tersebut dinamakan dengan acara Teras Akustik yang bertempat di Jalan Veteran Kabupaten Batang tepatnya di belakang Rumah Dinas Bupati Batang. 


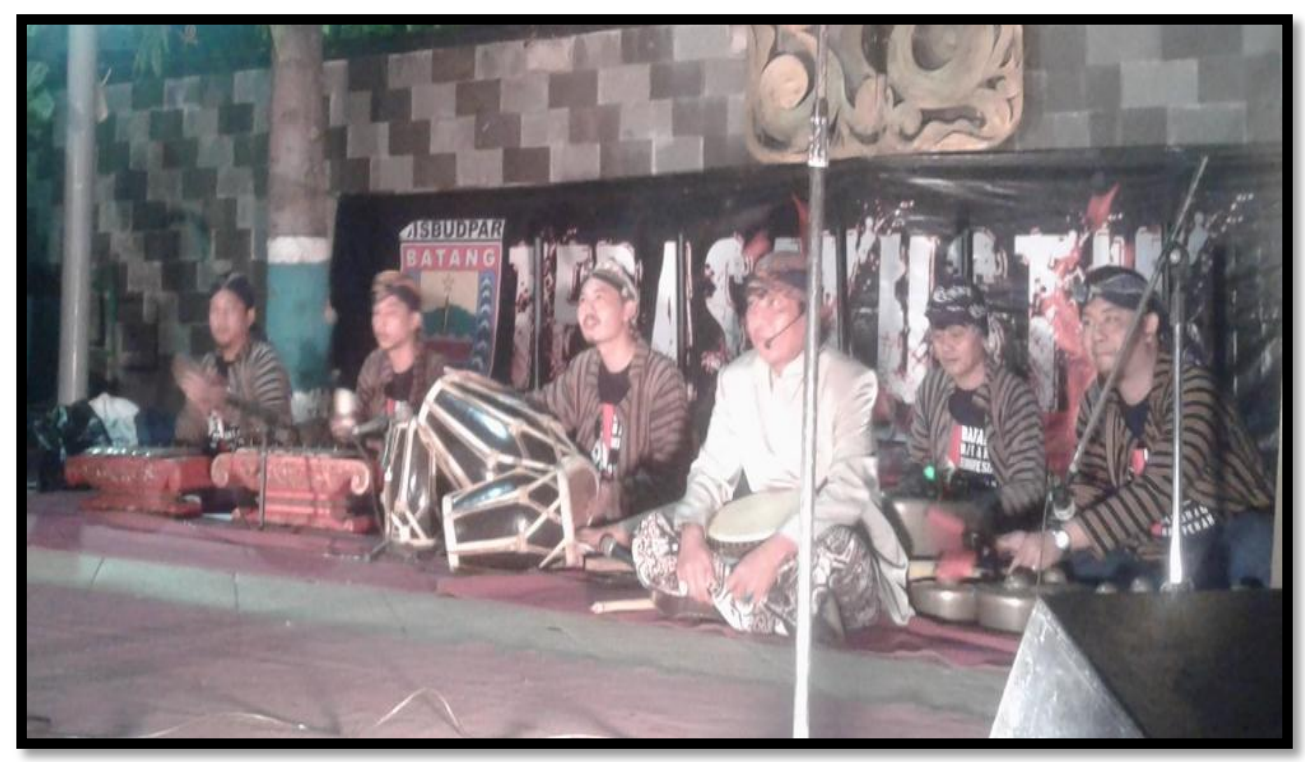

Foto 4.29 Instrumen Musik Kesenian Babalu (Sumber : Adilah Endarini, 30 Agustus 2016)

Pada foto 4.29 merupakan seperangkat instrumen musik Kesenian Babalu asal Kabupaten Batang yang dimainkan oleh para pemusik Sanggar Putra Budaya Desa Proyonanggan Kabupaten Batang yang bekerjasama dengan Dinas Kesenian Daerah Kabupaten Batang yang bertempat di Jalan Veteran depan pendopo Kabupaten Batang tepatnya disamping Rumah Dinas Bupati Batang.

Adapun alat musik yang digunakan dalam pementasan Kesenian Babalu terdiri dari, Kendhang, Kentongan, Rebana, Kenong, Saron, Demung, Kempul, Bonang, dan Gong serta terdiri dari 7 orang pemain alat musik dan 2 orang penari yaitu Ibu Suningsih dan Ibu Niken. Kedua penari tersebut merupakan pelatih tari di Sanggar Putra Budaya Desa Proyonanggan Kabupaten Batang. Berikut merupakan penjelasan masing-masing instrumen yang digunakan dalam kesenian Babalu di Sanggar Putra Budaya Desa Proyonanggan Kabupaten Batang. 


\subsection{Kendhang}

Kendhang merupakan instrumen dalam gamelan Jawa yang terbuat dari kayu nangka atau kelapa dan kulit kerbau/kambing. Kendhang yang terbuat dari Kulit kerbau digunakan pada permukaan bagian yang sering memancarkan ketukan bernada rendah sedangkan Kendhang dengan kulit kambing digunakan untuk memancarkan ketukan bernada tinggi. Kendhang mempunyai fungsi utama yaitu untuk mengatur suatu irama dalam.

Kendhang, atau biasa disebut juga dengan gendang merupakan alat musik yang dimainkan dengan cara di pukul. Instrumen Kendhang cukup dibunyikan dengan menggunakan gerakan tangan serta tanpa alat bantu lain. Kesenian Babalu menggunakan alat musik kendang agar menjadi suatu iringan yang lebih menarik dengan irama teratur. Berikut foto 4.30 merupakan alat musik kendhang.

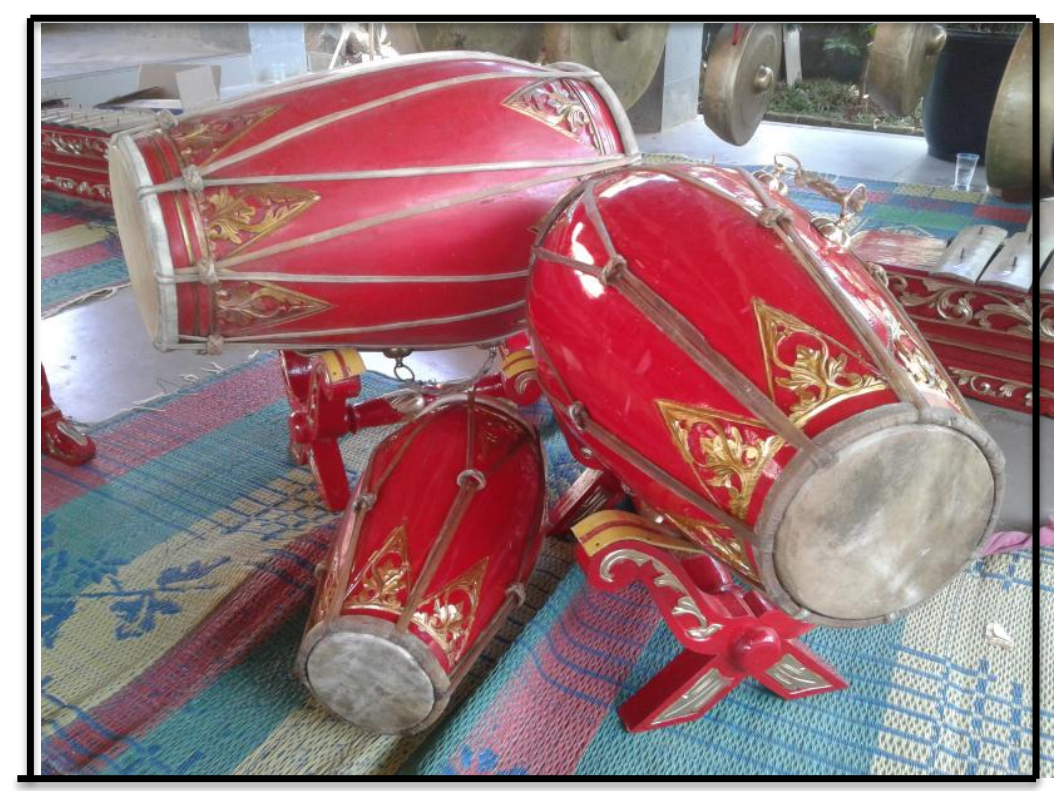

Foto 4.30 Alat Musik Kendhang

(Sumber : Adilah Endarini, 27 Juli 2017) 
Pada foto 4.30 merupakan alat musik kendang dimana cara memukul kendhang yaitu dengan kekuatan kedua tangan dalam memegang dan memukul bagian kulit kendang dengan teknik tertentu sampai suara atau bunyi kendhang yang keluar sesuai dengan bunyi yang ingin kita gunakan. Dengan alat musik kendhang, variasi musik yang terdapat dalam Kesenian Babalu Sanggar Putra Budaya Desa Proyonanggan Kabupaten Batang terasa lebih bersemangat dan lebih ramai.

\subsection{Kenong}

Kenong merupakan alat gamelan jawa yang terbuat dari logam yang menyebabkan suatu pantulan bunyi yang merdu. Kenong digunakan sebagai pengisi akor atau harmoni dalam memainkan gamelan. Berikut foto 4.31 adalah alat musik kenong :

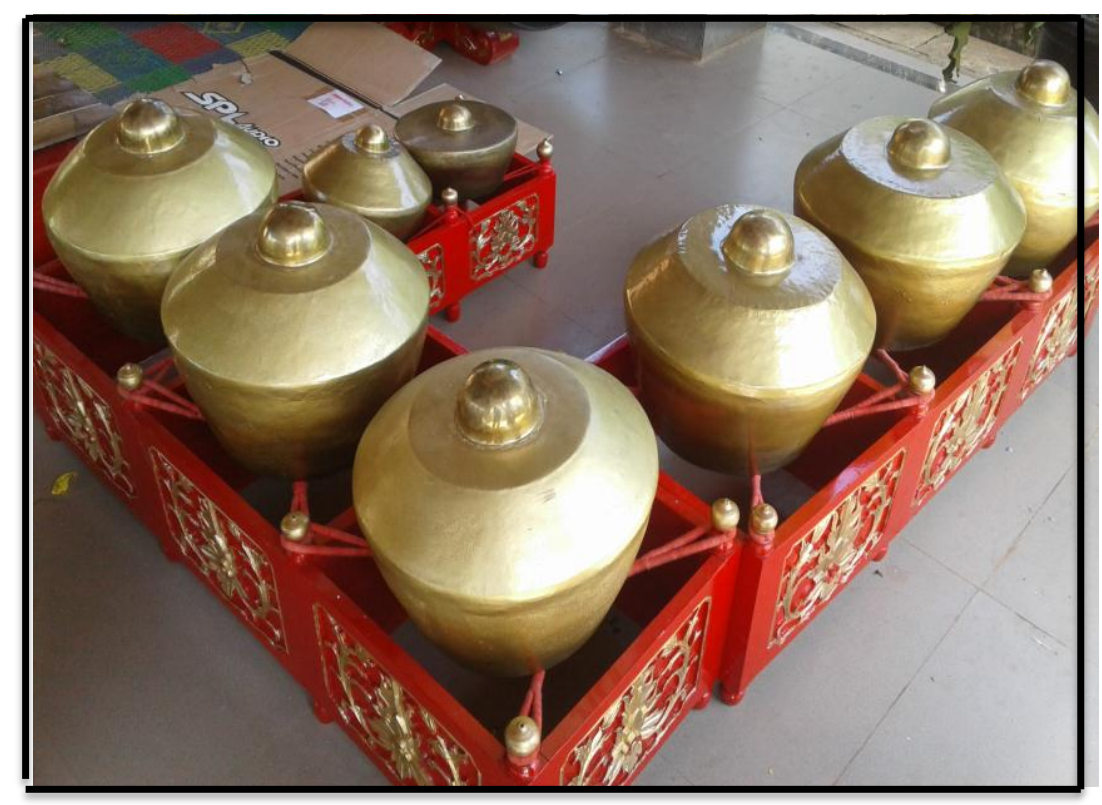

Foto 4.31 Alat Musik Kenong (Sumber : Adilah Endarini, 27 Juli 2017) 
Pada foto 4.31 merupakan alat musik kenong. Kenong berfungsi sebagai penentu batas-batas gatra, menegaskan irama. Kenong juga termasuk dalam alat musik dengan ukuran lebih besar daripada bonang. Cara memukul kenong yaitu dengan dipukul menggunakan alat pemukul kayu yang dililitkan kain.

Kenong dipukul dengan menggunakan tangan dan pemukul kayu yang dipukul pada bagian tengah yang paling menonjol kearah atas dengan memakai kekuatan pukulan yang tidak terlalu keras dan juga tidak terlalu lemah. Kesenian Babalu oleh Sanggar Putra Budaya menggunakan alat musik kenong karena alat musik kenong akan lebih mempermudah seorang penari ataupun penonton dalam menikmati tarian dan mengatur irama tempo dalam tarian.

Kenong ini disusun pada pangkon berupa kayu keras yang dialasi dengan tali, sehingga pada saat dipukul kenong tidak akan bergoyang ke samping namun dapat bergoyang ke atas bawah, sehingga menghasilkan suara. Bentuk kenong yang besar menghasilkan suara yang rendah namun nyaring dengan timber yang khas (dalam telinga masyarakat Jawa ditangkap berbunyi ning-nong, sehingga dinamakan kenong). Dalam gamelan, suara kenong mengisi sela-sela antara kempul.

\subsection{Alat Musik Demung}

Demung adalah salah satu instrumen gamelan yang termasuk keluarga balungan. Alat musik demung terbuat dari logam dan kayu. Cara memukul demung menggunakan kayu yang telah dibentuk agar memantulkan suara yang merdu. Berikut foto 4.32 adalah alat musik demung. 


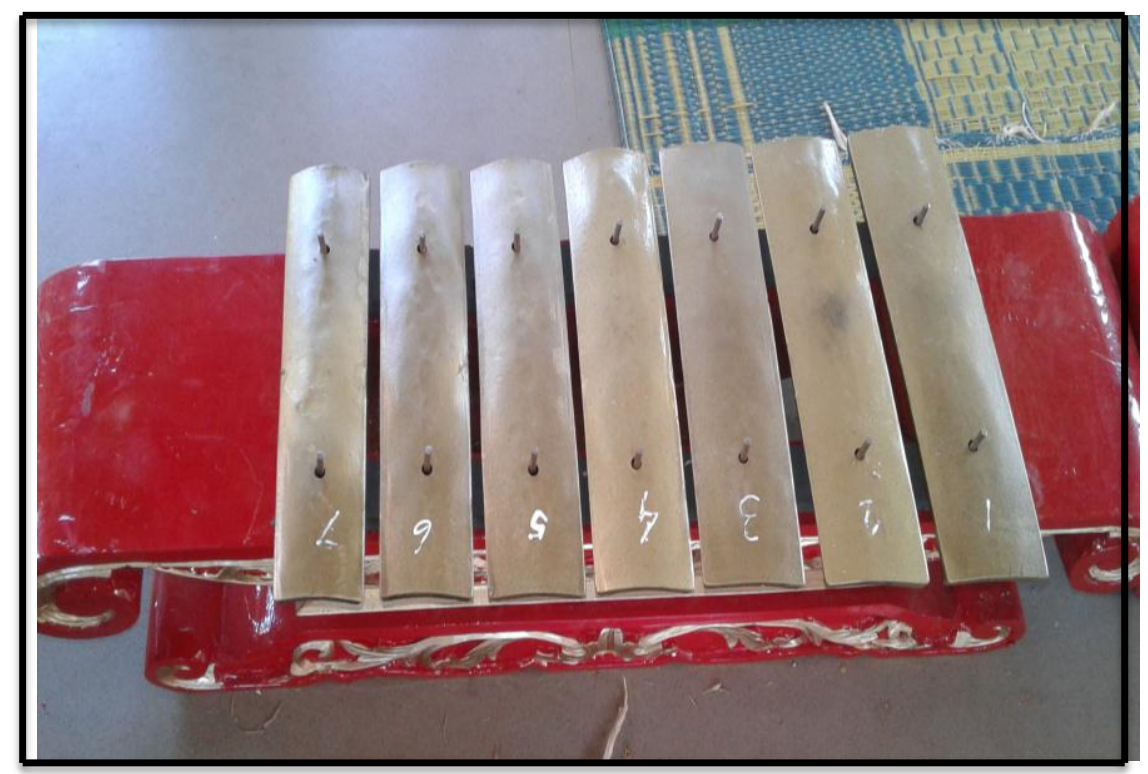

Foto 4.32 Alat Musik Demung

(Sumber : Adilah Endarini, 27 Juli 2017)

Foto 4.32 adalah alat musik demung. Demung adalah salah satu instrumen gamelan yang termasuk keluarga balungan. Dalam satu set gamelan biasanya terdapat 2 demung yang keduanya memiliki versi pelog dan versi slendro. Demung menghasilkan nada dengan oktaf terendah dalam keluarga balungan dengan ukuran fisik yang lebih besar. Kesenian Babalu yang berasal dari Sanggar Putra Budaya Desa Proyonanggan Kabupaten Batang menggunakan versi gamelan laras pelog

\subsection{Alat Musik Saron}

Saron atau yang biasanya disebut juga ricik, adalah salah satu instrumen gamelan yang termasuk keluarga balungan. Dalam satu set gamelan biasanya mempunyai 4 saron, dan semuanya memiliki versi pelog dan slendro. Berikut foto 4.33 alat musik saron : 


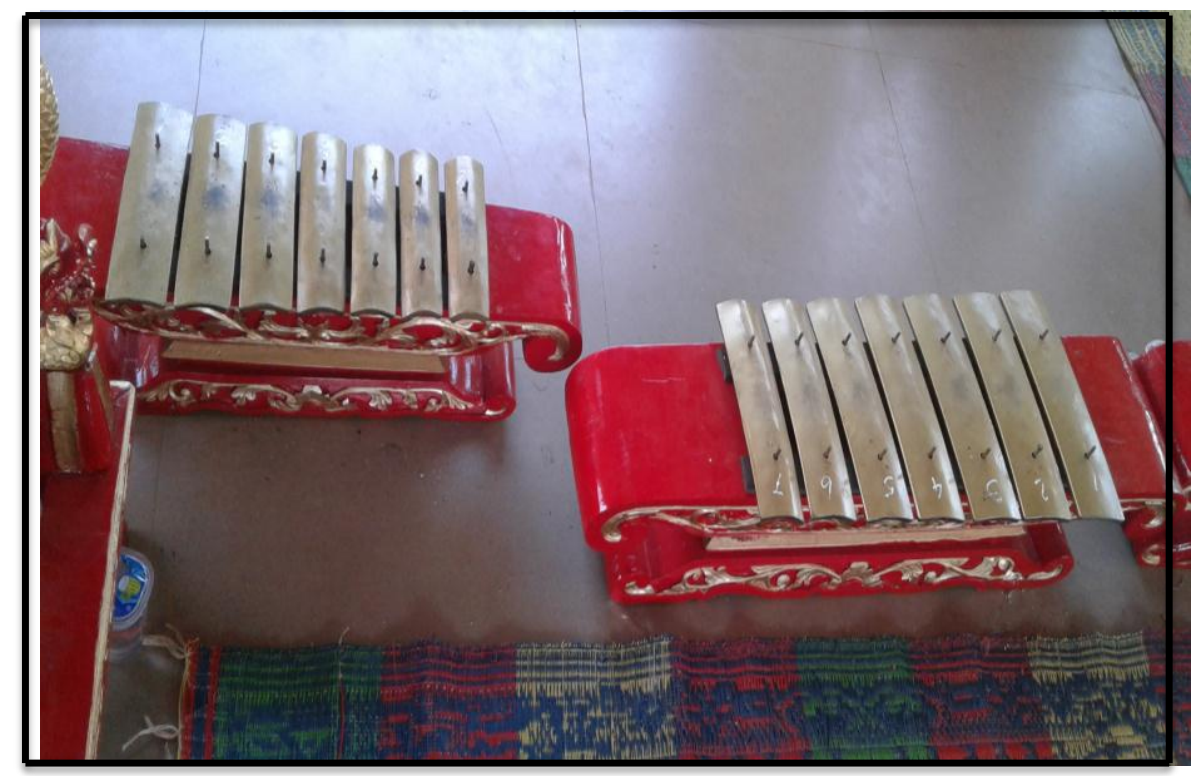

Foto 4.33 Alat Musik Saron

(Sumber : Adilah Endarini, 27 Juli 2017)

.Foto 4.33 merupakan alat musik saron. Alat musik saron dalam mengiringi kesenian Babalu menggunakan Laras Pelog. Alat pemukul saron terbuat dari kayu, bentuknya seperti palu yang hampir sama dengan bentuk alat pemukul demung. Cara memukul saron dalam kesenian Babalu yaitu dengan cara memukulkan kayu menuju pada tengah posisi lempengan saron sambil tangan kiri memitet atau menahan bunyi yang kurang pas dalam memukul saron.

\subsection{Alat Musik Kempul dan Gong}

Kempul merupakan salah satu perangkat gamelan yang ditabuh, biasanya digantung menjadi satu perangkat dengan Gong. Kempul termasuk bagian dari kelompok instrumen keras dari gamelan. Berikut foto 4.34 alat musik kempul dan gong. 


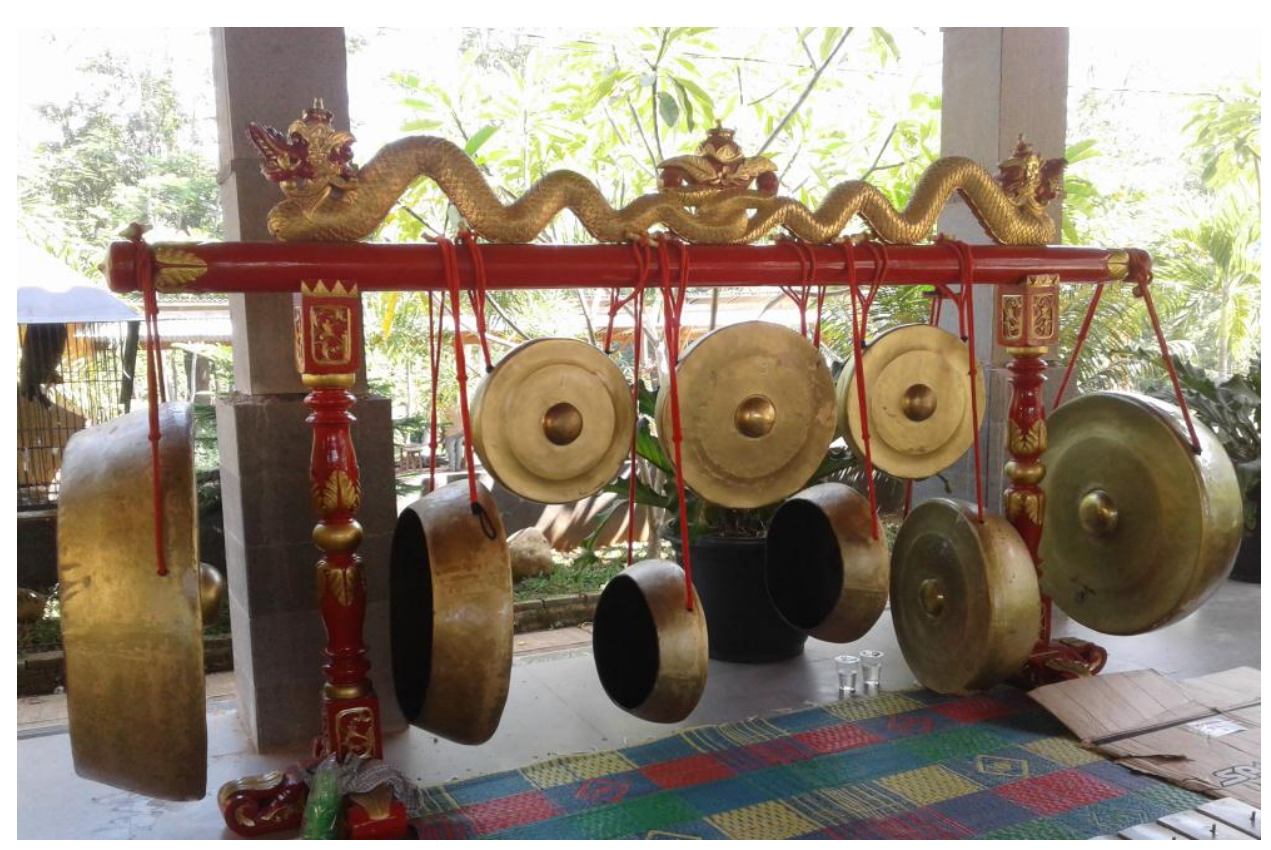

Foto 4.34 Alat Musik Kempul dan Gong

(Sumber : Adilah Endarini, 27 Juli 2017)

Foto 4.34 merupakan alat musik kempul dan gong. Cara memukul kempul yaitu dengan menggunakan kayu yang dililit pakai kain setelah itu dipantulkan kearah tengah lingkaran kecil yang terdapat di luar permukaan kempul. Pukul dan pantulkan kayu yang sudah dililit kain pelan-pelan kearah kempul agar bunyi yang dihasilkan sesuai.

\subsection{Alat Musik Rebana}

Rebana adalah alat musik gendang berbentuk bundar dan pipih yang merupakan khas suku melayu. Rebana merupakan alat musik dengan permukaan terbuat dari kulit kambing dengan bidang rangka terbuat dari kayu. Seperti pada foto 4.35 alat musik rebana sebagai berikut : 


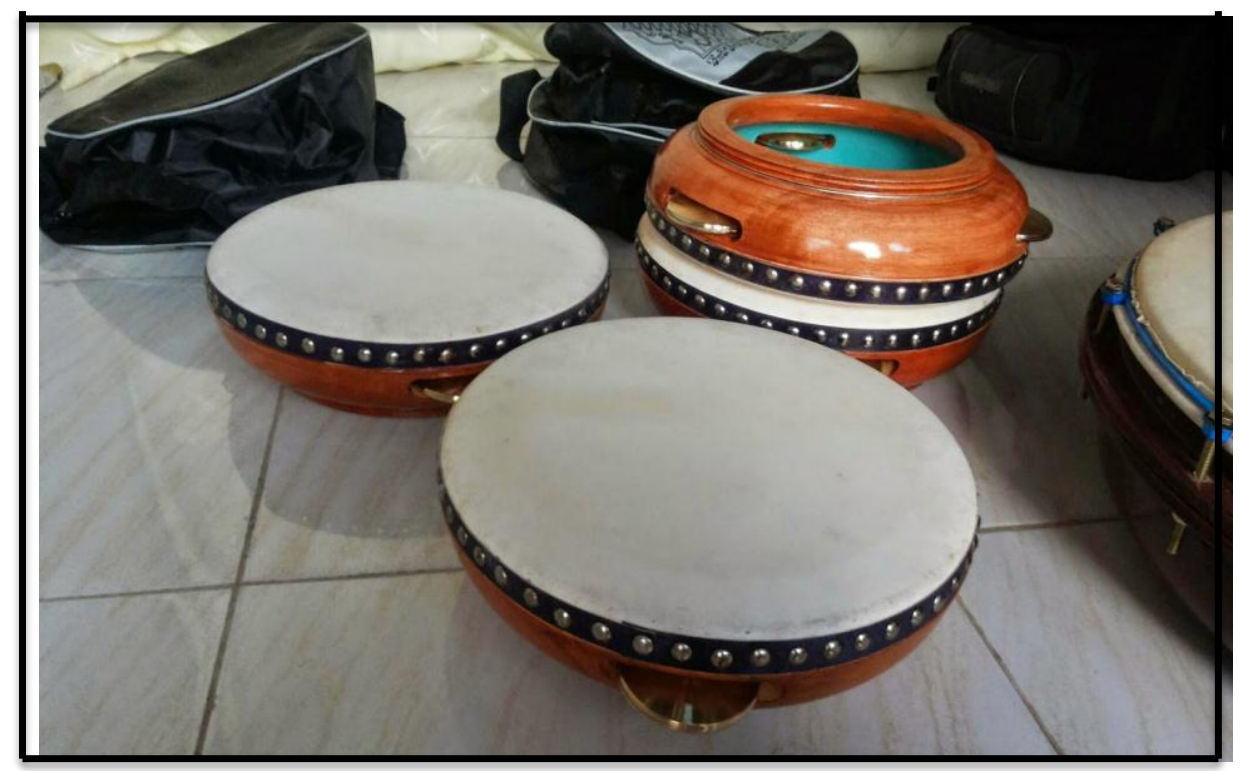

Foto 4.35 Alat Musik Rebana

(Sumber : Adilah Endarini, 27 Juli 2017)

. Foto 4.35 merupakan alat musik rebana. Rebana adalah suatu bingkai berbentuk lingkaran terbuat dari kayu yang dibubut, dengan salah satu sisi untuk ditepuk berlapis kulit kambing. Cara memukul rebana yaitu dengan menepukkan yangan secara beraturan sesuai irama ke posisi kulit kendang.

\subsection{Alat Musik Kentongan}

Alat musik kentongan merupakan alat yang digunakan dalam memainkan musik kesenian Babalu di Sanggar Putra Budaya kentongan atau yang dalam bahasa lainnya disebut alat musik jidor adalah alat pemukul yang terbuat dari batang bambu atau batang kayu jati yang dipahat. Berikut foto 4.36 merupakan alat musik Kentongan yang dipakai dalam pertunjukan Kesenian Babalu asal Kabupaten Batang. 


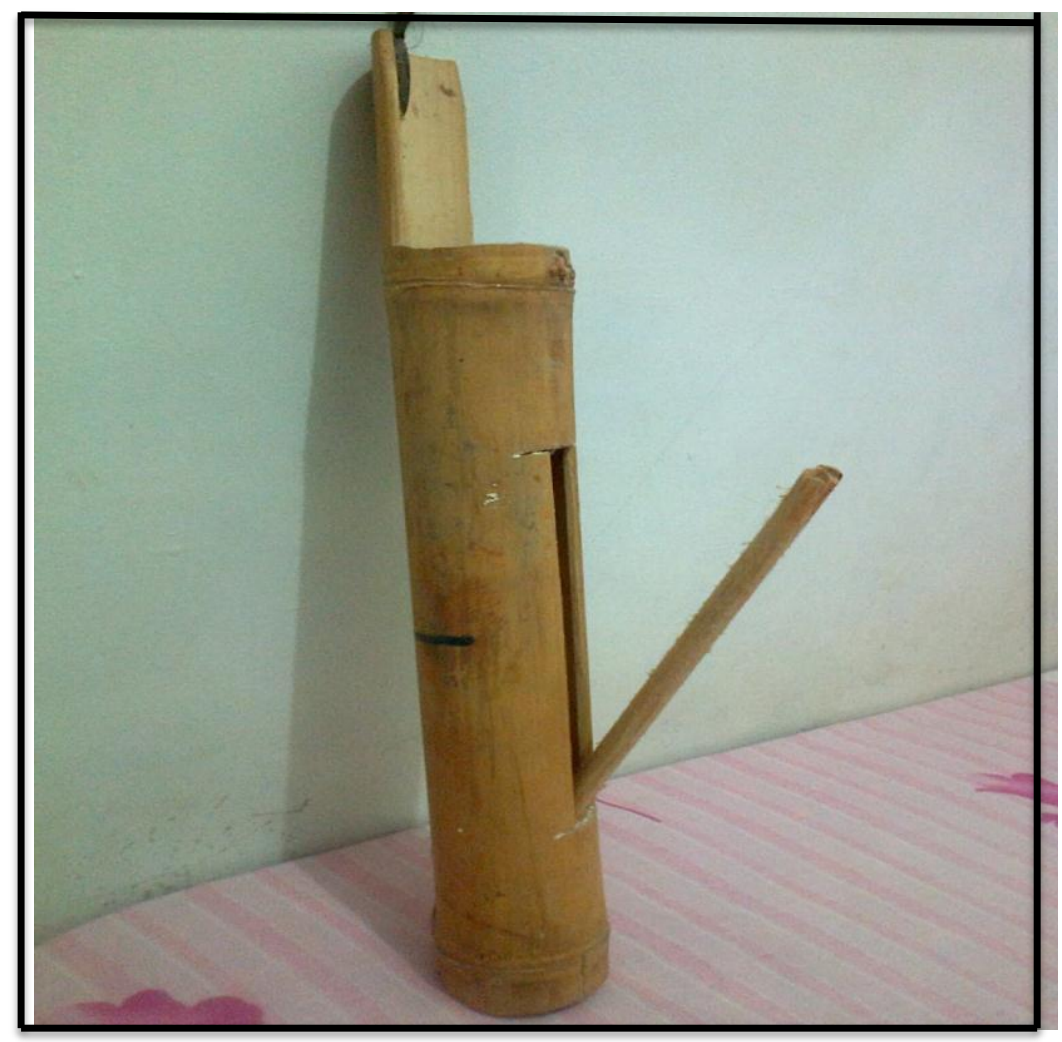

Foto 4.36 Alat Musik Kentongan

(Sumber : Adilah Endarini, 27 Juli 2017)

Foto 4.36 merupakan Alat Musik Kentongan. Cara memukul alat musik kentongan yaitu dengan cara dipukul menggunakan kayu kecil yang telah disediakan khusus untuk memukul kentongan. Selain alat musik yang digunakan seperti kendhang, kenong, bonang, rebana, kempul, gong, saron, demung dan kentongan/jidor, dalam pertunjukan Kesenian Babalu juga terdapat vokal, vokal dalam kesenian Babalu menggunakan tembang berupa tembang Babalu Mbatang dan tembang Ilir-ilir, berikut merupakan syair dan notasi lagu yang terdapat dalam Kesenian Babalu di Sanggar Putra Budaya Desa Proyonanggan Kabupaten Batang. 


\subsection{Syair Lagu Babalu Mbatang}

Asalmulane Babalu Mbatang

Sing wis ono kadek jaman perjuangan

Digunaake kanggo siasat perang

Pie carane pie menange

Mbang cepokokuning cepokokuning kembang melati

Mari kita nikmati kesenian Babalu ini

Terjemahan Syair lagu Babalu Mbatang

Asalmulanya Babalu Batang

Sudah ada dari zaman perjuangan

Digunakan untuk siasat perang

Gimana caranya, gimana menangnya

Bunga cempaka kuning cempaka putih bunga melati

Mari kita nikmati kesenian Babalu ini

(Sumber : Wawancara Suprayetno, 3 april 2017)

\subsection{Syair Lagu Lir-ilir}

Lir ilir lir ilir

Tandure wus sumilir

Tak ijo royo-royo

Tak sengguh temanten anyar

Cah angon, cah angon

Penekno blimbing kui

Lunyu-lunyu penekno

Kanggo mbasuh dodotiro

Dodotiro dodotiro

Kumintir bedhah ing pinggir

Dondomono, Jlumatono

Kanggo sebo mengko sore

Mumpung padhang rembulane

Mumpung jembar kalangane

Yo surako surak iyo. 
Terjemahan Syair lagu Lir-ilir

Lir ilir lir ilir

Tumbuhannya sudah menghijau

Demikian menghijau

Bagaikan pengantin baru

Anak gembala, anak gembala

Panjatlah pohon blimbing itu

Biar licin dan susah tetaplah kau panjat

Untuk membasuh pakaianmu

Pakaianmu, pakaianmu

Terkoyak-koyak dibagian samping

Jahitlah, benahilah

Untuk menghadap nanti sore

Mumpung bulan bersinar terang

Mumpung banyak waktu luang

Bersoraklah dengan sorakan iyo

(Sumber: Wawancara Suprayetno, 3 april 2017)

Syair dalam lagu Babalu Mbatang mempunyai arti yang ada kaitannya dengan sejarah Kesenian Babalu yaitu menunjukan bahwa kesenian Babalu sudah hidup sejak jaman perjuangan dan digunakan sebagai siasat perang. Para pejuang mencari cara agar dapat mengalahkan penjajah yaitu dengan menggunakan kode/peluit dan suatu tarian untuk mengelabuhi penjajah dan disuguhi minuman, hingga akhirnya para pejuang berhasil melawan penjajah yang telah lengah.

Selain syair lagu didalam kesenian Babalu di Sanggar Putra Budaya Desa Proyonanggan Kabupaten Batang juga terdapat notasi musik lagu Babalu Mbatang serta Ilir-ilir, berikut notasi musik pengiring kesenian Babalu dengan lagu Babalu Batang. 
4.4.2.2.10 Notasi gending Babalu Mbatang (PL)

\section{Babalu Mbatang}

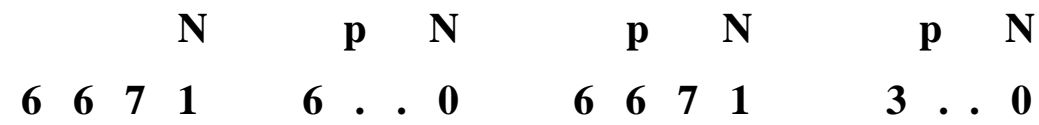

A sal mula ne Babalu mba tang

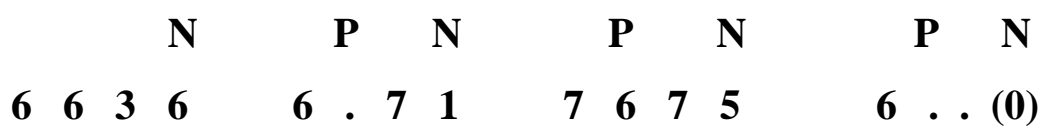

Singwiso no ka dekja manperjuang an

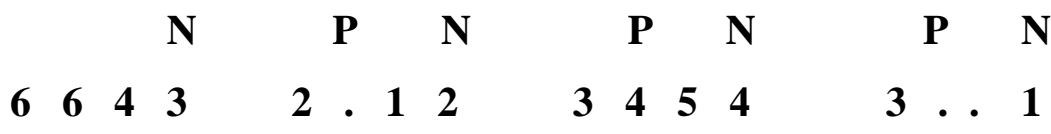

$\begin{array}{lllllll}\text { Di gu na a } & \text { ke } & \text { kanggo } & \text { si } & \text { a } & \text { sat pe } & \text { rang }\end{array}$

\begin{tabular}{|c|c|c|c|c|c|c|c|c|c|}
\hline & & $\mathbf{N}$ & & $\mathbf{P}$ & $\mathbf{N}$ & & $\mathbf{P}$ & $\mathbf{N}$ & \\
\hline 2 & . 2 & 7 & 1 & . & 6 & 7 & 21 & 7 & 6 \\
\hline
\end{tabular}

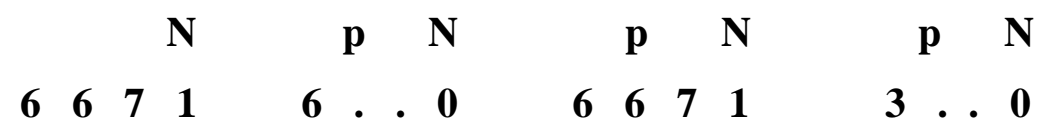

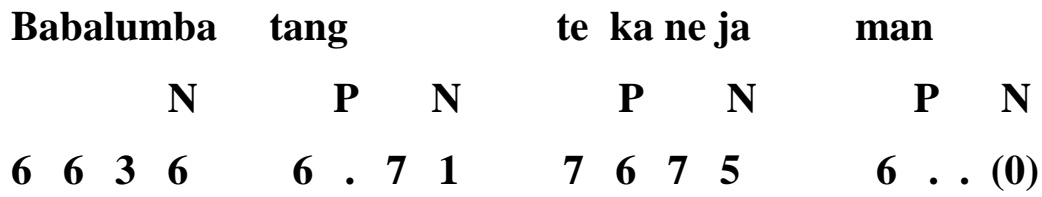

Di u ri u ri dade kake se nian

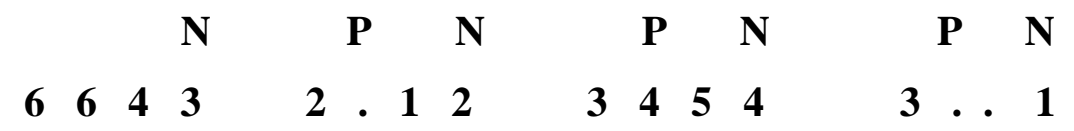


Ningkotamba tang slo gan Batang berkem bang a

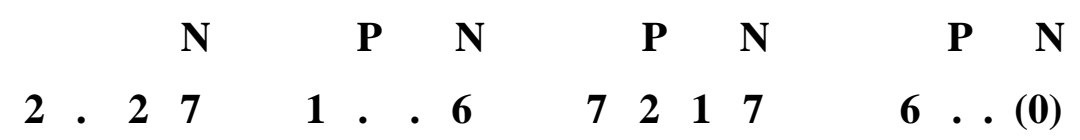

Man daerah e mak mursejati ne

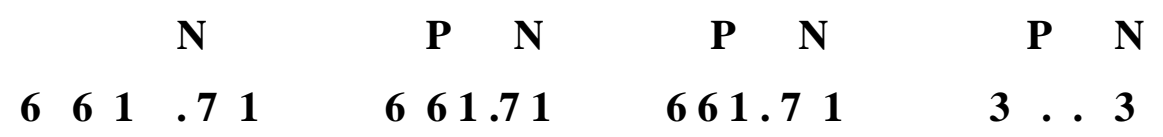

Mbangcempokko ningcempokopu tihkembangme lati ma

\begin{tabular}{lcccccc}
\multicolumn{1}{c}{ N } & P & N & P & N & P & N \\
443.21 & 3.216 & 772.17 & 6 & $\ldots(0)$ \\
rikita nikma & ti & ke se ni & an babalui & ni &
\end{tabular}

(Sumber : Wawancara Suprayetno, 3 April 2017)

$$
\begin{aligned}
\text { Keterangan : } & \mathrm{N}=\text { Kenong } \\
\mathrm{P} & =\text { Kempul } \\
(\mathrm{O} & =\text { Gong }
\end{aligned}
$$




\section{Lir Ilir}

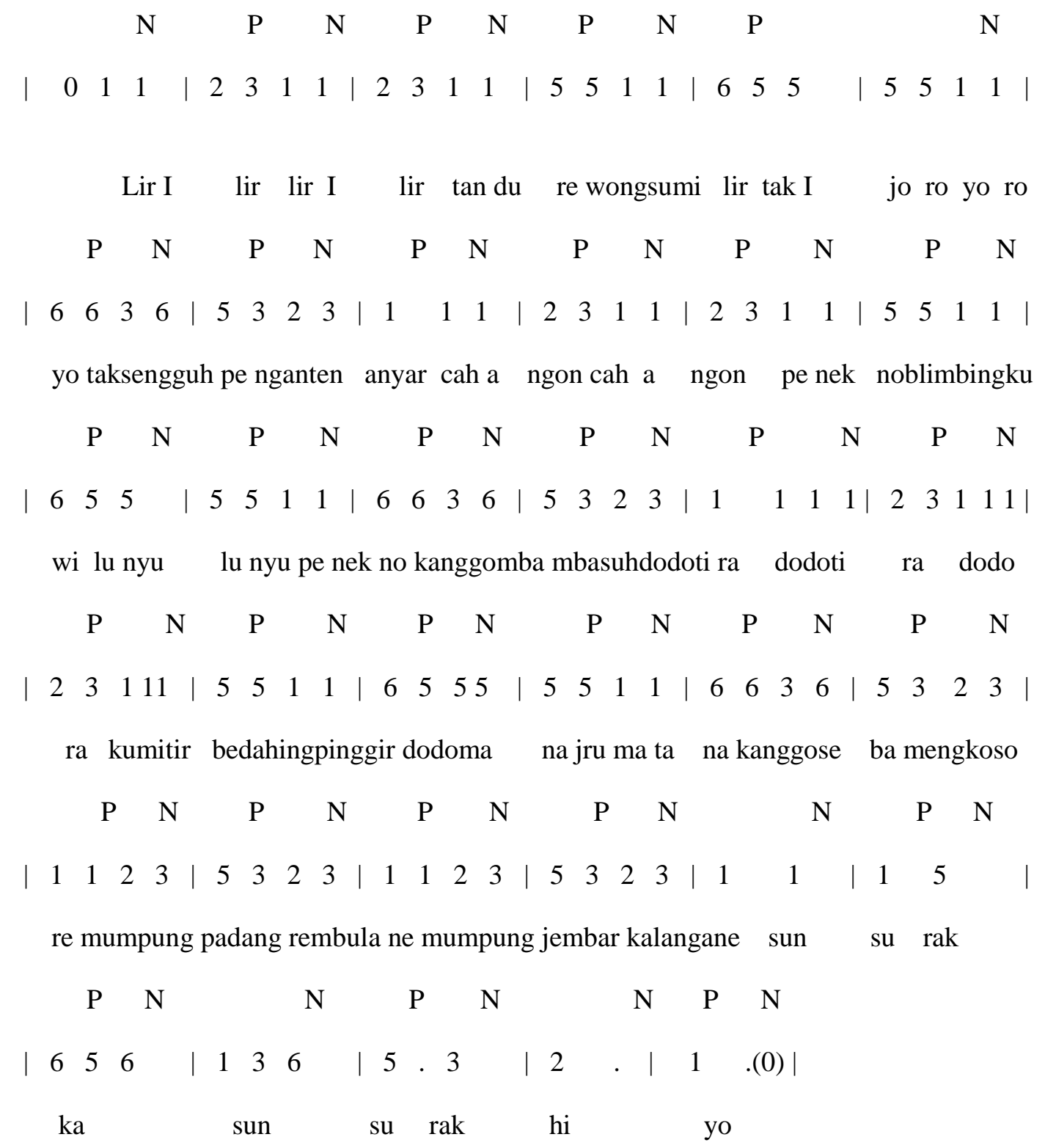

Sumber : Wawancara Suprayetno, 3 April 2017)

Keterangan :

$\mathrm{N}=$ Kenong

$\mathrm{P}=$ Kempul

$(0)=$ Gong 


\subsubsection{Tata Rias Kesenian Babalu di Sanggar Putra Budaya Desa Proyonanggan Kabupaten Batang}

Tata rias pada Kesenian Babalu menggunakan rias corrective make up, yaitu rias wajah cantik. Rias korektif adalah rias untuk mempertegas bagianbagian wajah sesuai karakter yang dibawakan. Tata rias tetap konsisten terhadap kaidah-kaidah yang diperlukan dalam pertunjukan tari, maka perlu diperhatikan prinsip-prinsip penataan rias tari yang diantaranya adalah: 1) Rias hendaknya mencerminkan karakter tokoh/peran, 2) Kerapian dan kebersihan rias perlu diperhatikan, 3) Jelas garis-garis yang dikendaki.

Alat rias yang digunakan pada riasan Kesenian Babalu adalah bedak dasar, bedak tabur, bedak padat, pensil alis, eye shadow, lipstick, dan blash on. Awal merias cantik adalah dengan menggunakan bedak dasar. Bedak dasar digunakan pada wajah yang sudah bersih, kemudian setelah bedak dasar sudah merata, dilanjutkan dengan menggunakan bedak tabur, hal ini digunakan untuk menghaluskan muka lalu menggunakan bedak padat yang ditumpukan dengan bedak dasar dan bedak tabur. Setelah bedak sudah merata penggunaanya, dilanjutkan dengan pembuatan alis mata menggunakan pensil alis berwarna coklat.

Eyeshadow yang digunakan dalam pertunjukan Kesenian tidak harus menggunakan warna yang sama, tetapi biasanya menyesuaikan dengan warna kostum. Setelah pewarnaan eyeshadow, dilanjutkan dengan penggunaan blash on yang digunakan untuk menonjolkan tulang pipi sehingga pipi terlihat lebih merona. Dan pada akhir rias menggunakan lipstick yang digunakan untuk menunjang kecantikan bibir. Seperti pada foto 4.11 berikut. 


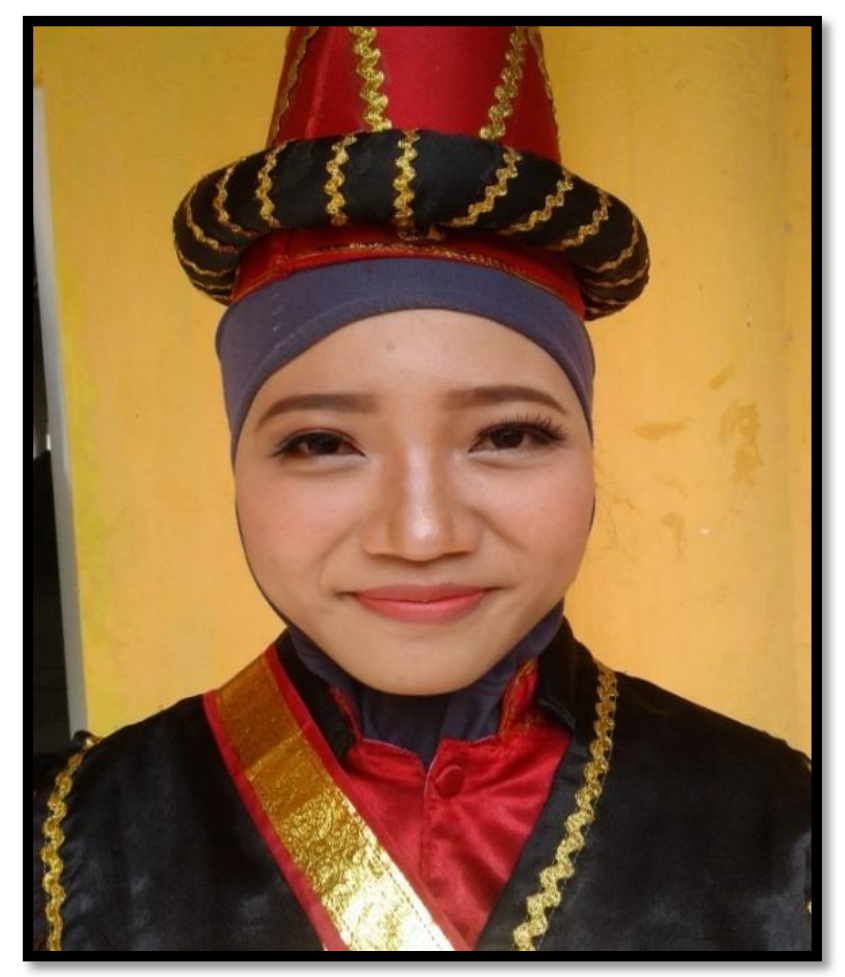

Foto 4.37 Rias wajah Kesenian Babalu Sumber : Adilah Endarini, 2 April 2017

Foto 4.37 merupakan rias wajah yang digunakan dalam Kesenian Babalu. Kesenian Babalu menggunakan rias cantik untuk memperindah dan memberi kesan segar pada wajah. Rias yang digunakan pada rias cantik dalam Kesenian Babalu menggunakan bedak dasar bedak tabur, bedak, pensil alis, eyeshadow, lipstick, dan blash on untuk mempertajam garis-garis wajah.

\subsubsection{Tata Busana Kesenian Babalu}

Tata Busana dalam Kesenian Babalu menggunakan Busana dengan warna merah, hitam dan emas. Warna dalam suatu tarian menunjukan makna, dalam Kesenian Babalu warna merah merupakan warna yang menunjukan rasa keberanian yang dibawakan oleh kaum wanita, lalu warna hitam merupakan suatu semangat yang penuh dengan kehati-hatian dalam melawan penjajah, dan warna 
emas menunjukan suatu kesuburan dan kegotong-royongan masyarakat Kabupaten Batang dalam melawan penjajah yang datang. Tata busana adalah segala tindakan untuk memperindah diri agar kelihatan menarik. Tata busana yang digunakan dalam pertunjukan Kesenian Babalu menyimbolkan keprajuritan, adapun tata busana yang dikenakan dalam Kesenian Babalu yang berasal dari Sanggar Putra Budaya Desa Proyonanggan Kabupaten Batang yaitu : rompi, slempang, kupluk berkucir, rapek, sabuk, celana merah, baju merah, kaoskaki dan kacamata. Berikut foto 4.38 adalah lengkap tata busana Kesenian Babalu.

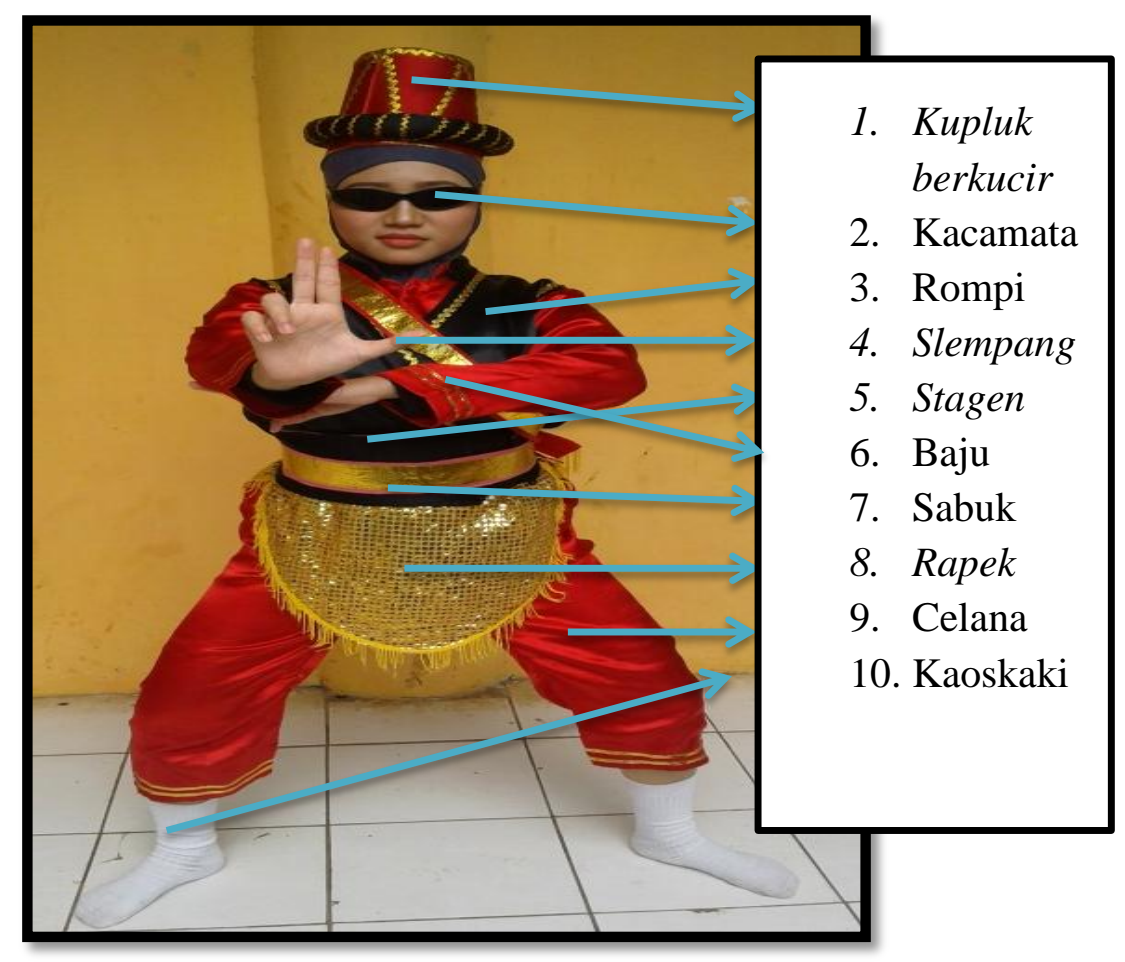

Foto 4.38 Tata Busana Kesenian Babalu Sumber: Adilah Endarini, 2 April 2017

Pada foto 4.38 merupakan tata busana dalam Kesenian Babalu yang terdiri 9 nama, nomer (1) yaitu Kupluk Berkucir lalu nomer (2) yaitu Kacamata, selanjutnya yaitu nomer (3) yaitu rompi. Pada nomer (4) yaitu Slempang. 
Kemudian nomer (5) yaitu baju. Nomer (6) yaitu sabuk. Nomer (7) yaitu Rapek. Nomer (8) yaitu celana, yang berfungsi untuk menutupi bagian kaki dan mengikat kostum-kostum yang lain. Nomer (9) yaitu Kaos Kaki yang berfungsi sebagai identitas masyarakat pantura serta warna kaos kaki yang putih menunjukan kesucian para penari dalam melestarikan Kesenian Babalu.

\subsubsection{Celana Merah}

Kostum celana berwarna merah disertai jahitan berwarna emas yang membentuk dua garis pada bagian bawah celana dalam Kesenian Babalu menunjukan rasa semangat penuh keberanian. Seperti pada foto 4.39 berikut.

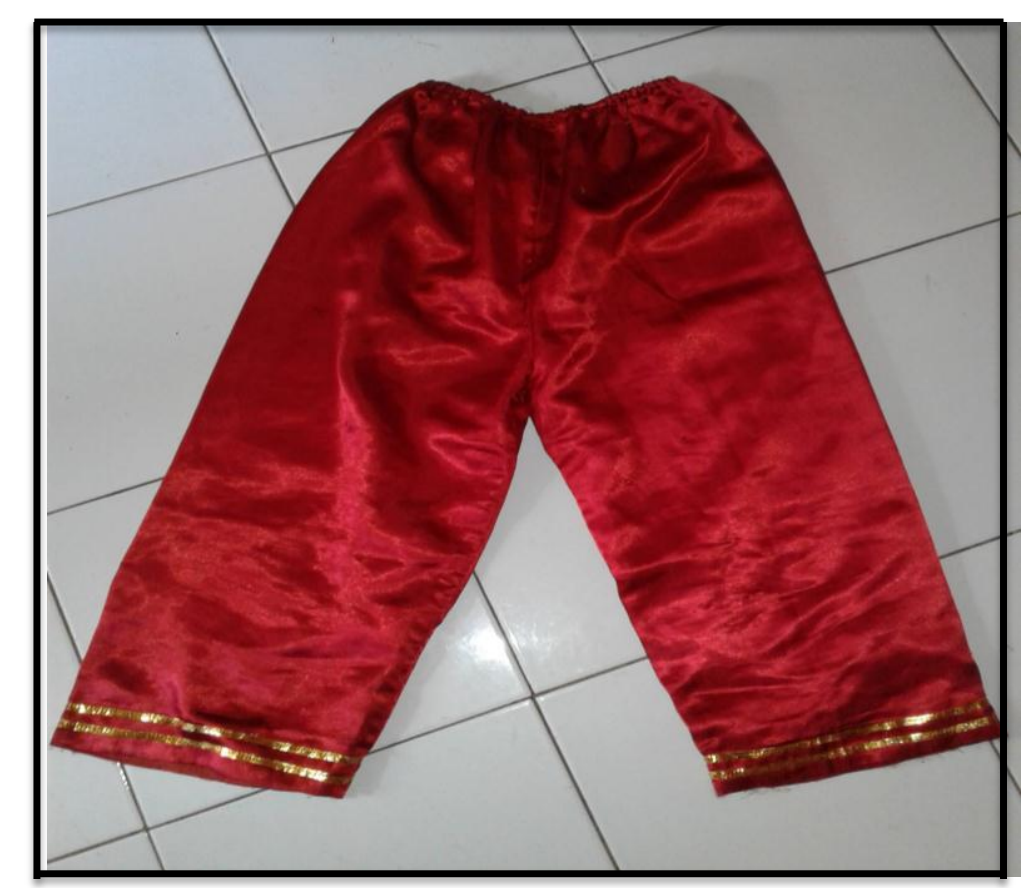

Foto 4.39 Kostum Celana Merah (Sumber : Adilah Endarini, 2 April 2017)

Foto 4.39 adalah kostum celana merah yang digunakan dalam Kesenian Babalu di Sanggar Putra Budaya Desa Proyonanggan Kabupaten Batang dan 
berguna untuk menutupi bagian paha dalam serta menunjukan rasa keberanian seorang pejuang wanita yang ingin melawan penjajah tanpa harus bercucuran darah.

\subsubsection{Baju Merah}

Kostum atasan Baju merah pada kesenian Babalu di Kabupaten Batang menunjukan rasa keberanian para pejuang pada jaman dahulu dalam melawan penjajah yang akan datang. Kostum baju merah ini juga dijadikan kostum pelengkap karena untuk melindungi bagian tubuh dan sebagai tempat dasar sebelum memakai perlengkapan kostum yang lain. Seperti pada foto 4.40 berikut.

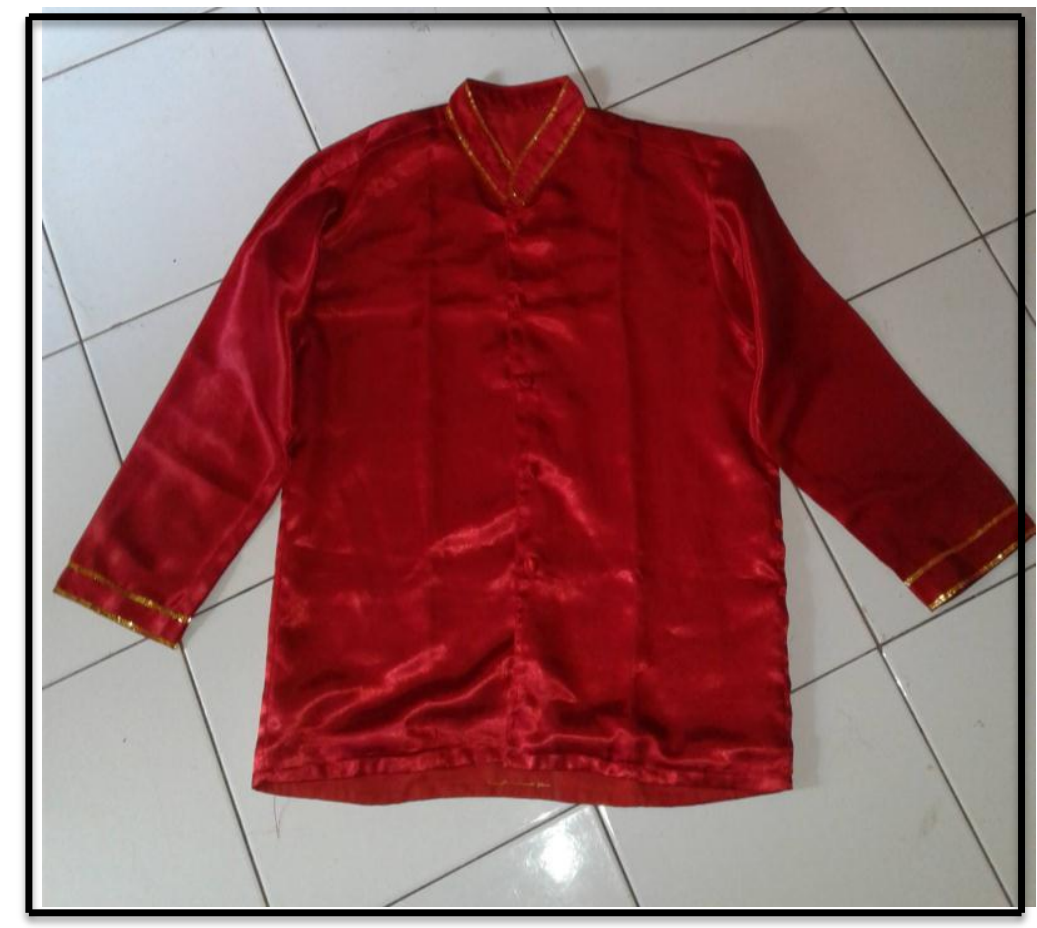

Foto 4.40 Kostum Atasan Baju Merah (Sumber : Adilah Endarini, 2 April 2017) 
.Foto 4.40 merupakan Kostum baju merah dalam Kesenian Babalu yang mempunyai makna bahwa generasi muda harus selalu tetap bersemangat dan berani dalam menghadapi suatu rintangan seperti jiwa para pejuang yang telah gugur demi mempertahankan kemerdekaan Negara Indonesia. Kostum selanjutnya dalam Kesenian Babalu yang berasal dari Sanggar Putra Budaya Desa Proyonanggan Kabupaten Batang yaitu Sabuk.

\subsubsection{Sabuk}

Sabuk merupakan kostum yang berguna untuk mengikat dan memberi garis bentuk pada tubuh. Sabuk dalam kostum Kesenian Babalu di Sanggar Putra Budaya berfungsi sebagai pengikat pinggang dan juga sebagai hiasan pada sebuah kostum. Seperti pada foto 4.41 berikut.

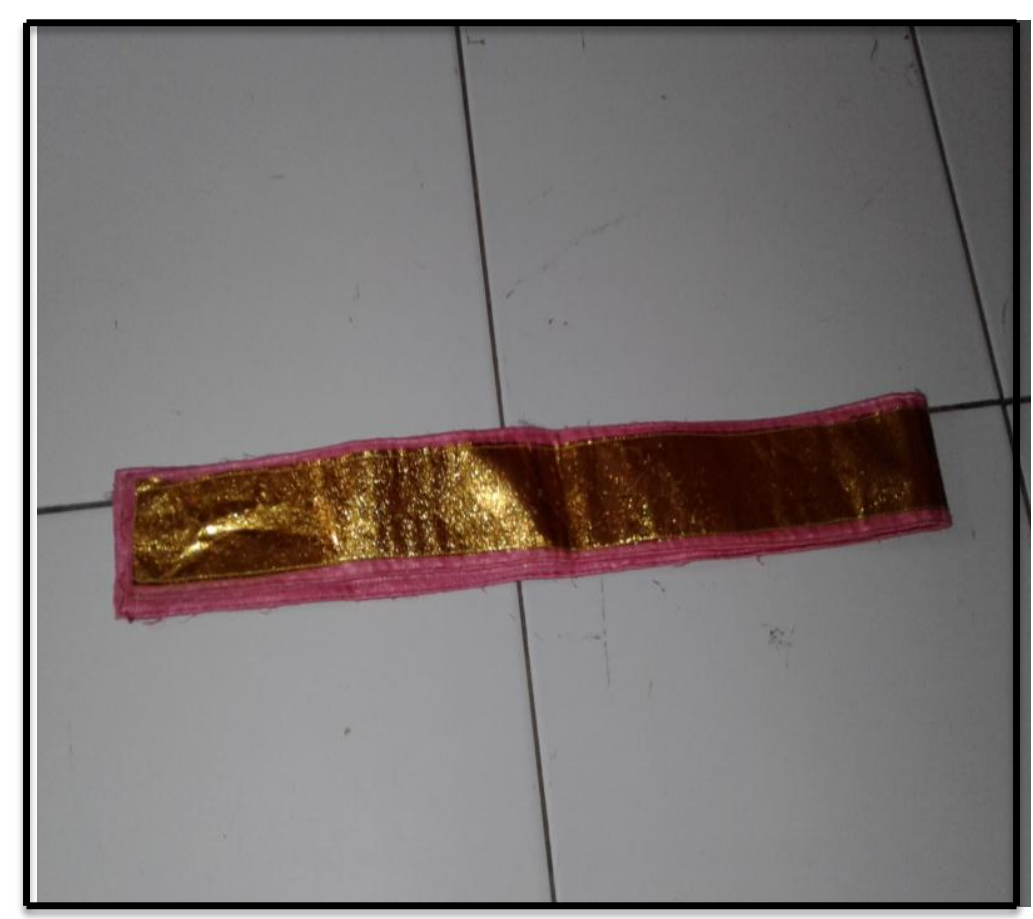

Foto 4.41 Sabuk

(Sumber : Adilah Endarini, 2 April 2017) 
Foto 4.41 merupakan Sabuk yang terdapat pada Kesenian Babalu di Sanggar Putra Budaya Desa Proyonanggan Kabupaten Batang yang mempunyai makna bahwa ikatan persaudaraan harus tetap dijaga dengan baik agar hidup kita kelak akan menjadi lebih bahagia. Dengan menjaga ikatan silaturahmi jiwa akan terasa lebih tenang, hidup rukun dan saling tolong-menolong antar sesama manusia. Warna yang terdapat didalam sabuk yaitu warna emas, namun untuk warna yang di gunakan dalam kostum kesenian Babalu boleh dikreasikan agar terlihat lebih menarik, boleh sabuk berwarna merah campur hitam, atau warna kuning campur merah akan tetapi dengan adanya pngembangan kostum dalam kesenian Babalu, kesenian ini harus tetap menjaga nilai-nilai tradisi yang di jadikan ciri khas kesenian Babalu pada jaman dahulu.

\subsubsection{Slempang}

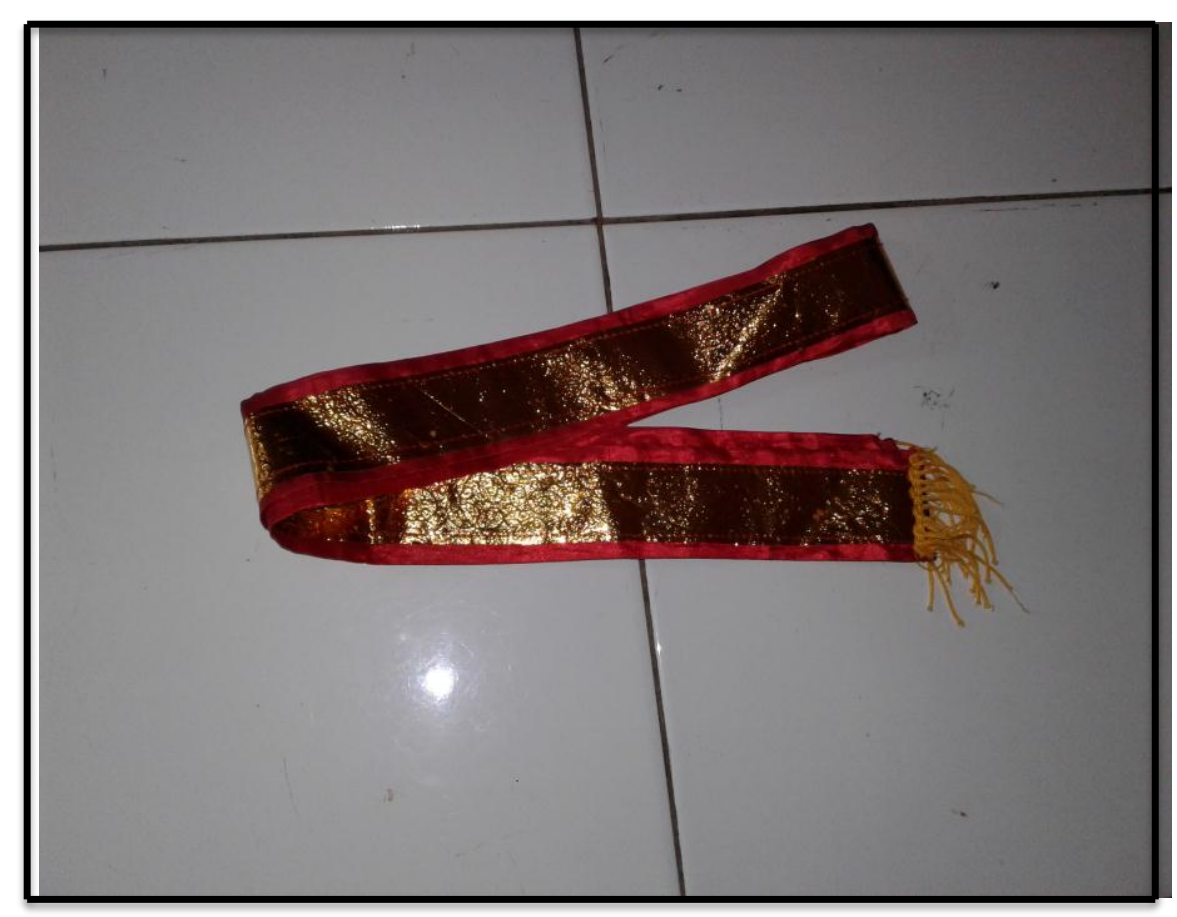

Foto 4.42 Slempang

(Sumber : Adilah Endarini, 2 April 2017) 
Foto 4.42 merupakan Slempang pada kesenian Babalu yang berada di Sanggar Putra Budaya Desa Proyonanggan Kabupaten Batang mempunyai makna bahwa seseorang yang memakai slempang adalah seorang pahlawan yang rela berkorban dalam melawan penjajah yang menyerang wilayahnya.

\subsubsection{Rapek}

Rapek merupakan hiasan kostum pada kesenian Babalu yang berwarna kuning mengkilap dan di pakai di daerah depan badan bagian paha dan belakang badan bagian paha. Seperti pada foto 4.43 berikut.

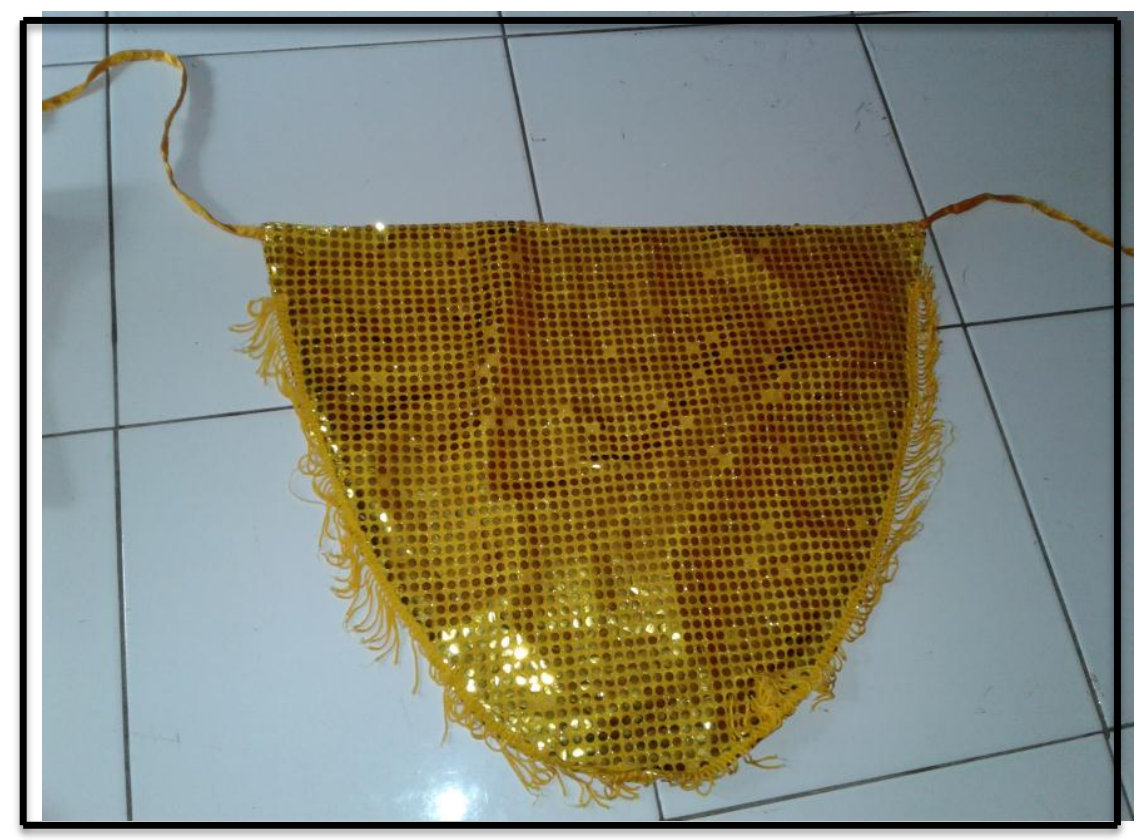

Foto 4.43 Rapek

(Sumber : Adilah Endarini, 2 April 2017)

Foto 4.43 Rapek merupakan Kostum yang digunakan pada Kesenian Babalu oleh Sanggar Putra Budaya Desa Proyonanggan Kabupaten Batang. Rapek digunakan pada bagian paha depan untuk sedikit menutupi pertigaan pada paha serta memberi kesan aksesoris yang bercahaya dan mengkilap. 


\subsubsection{Rompi Hitam}

Rompi yang berwarna hitam adalah salah satu bagian kostum dalam Kesenian Babalu di Sanggar Putra Budaya Desa Proyonanggan Kabupaten Batang. Seperti pada foto 4.43 berikut.

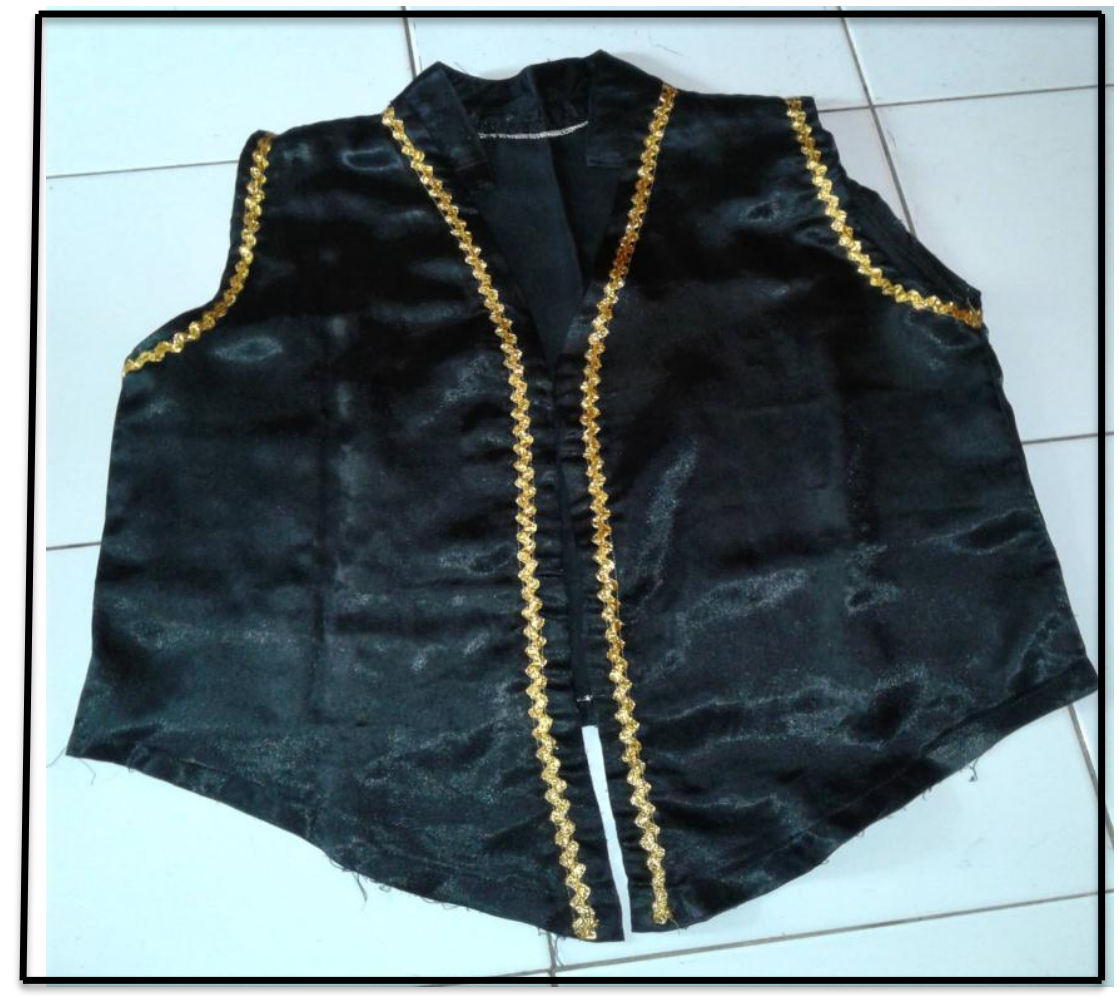

Foto 4.44 Rompi

(Sumber : Adilah Endarini, 2 April 2017)

Foto 4.44 merupakan rompi hitam yang dalam pemakaiannya rompi berwarna hitam berfungsi sebagai penghangat tubuh serta menyimbolkan kekebalan seorang prajurit masyarakat Kabupaten Batang dalam melawan musuh yang akan datang. Selanjutnya yaitu Kacamata yang digunakan oleh penari Kesenian Babalu Kabupaten Batang sebagai berikut : 


\subsubsection{Kacamata}

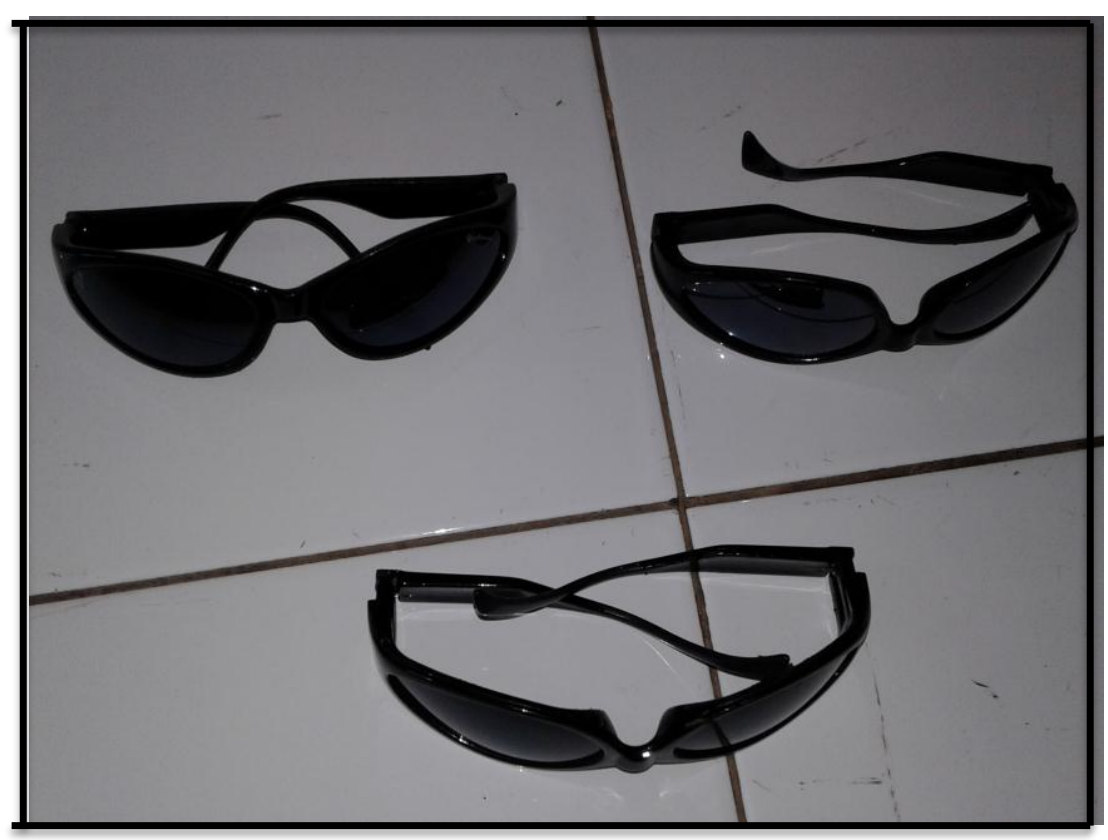

Foto 4.45 Kacamata

(Sumber : Adilah Endarini, 2 April 2017)

Foto 4.45 merupakan kacamata yang dipakai dalam pertunjukan Kesenian Babalu adalah kacamata yang mempunyai fungsi untuk sebuah penyamaran diri terhadap penjajah pada jaman dahulu, selain itu juga berfungsi sebagai identitas wilayah pesisiran yang identik dengan cuaca panas, maka fungsi kacamata yaitu untuk melindungi mata dari terik matahari (Wawancara, Suprayetno 3 April 2016).

\subsubsection{Stagen}

Stagen adalah kain tenun dengan panjang kurang lebih 3-5 meter dengan lebar 20 sentimeter. Fungsi stagen yaitu melilitkan dan mengencangkan kain jarik yang telah dipakai sebelumnya agar tidak lepas, seperti pada foto 4.46 berikut. 


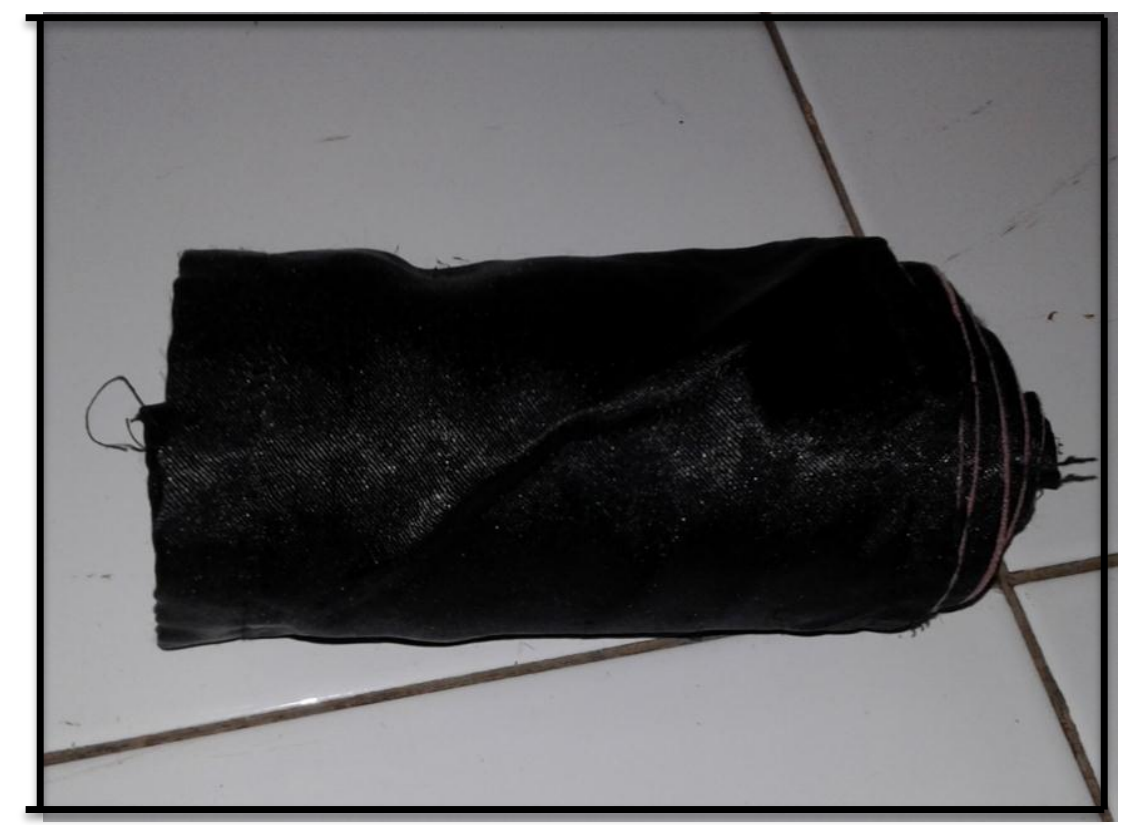

Foto 4.46 Stagen

(Sumber : Adilah Endarini, 2 April 2017)

Foto 4.46 adalah stagen yang digunakan dalam tata busana Kesenian Babalu yang berwarna gelap dengan panjang 3 meter. Cara penggunaannya dengan dililitkan setelah penggunaan celana merah dari bagian pinggul hingga dada (penari putri) kemudian diberi peniti di ujung stagen agar tidak lepas. Penggunaan stagen pada busana penari Kesenian Babalu menimbulkan kesan rapi setelah mengenakan celana merah.

\subsubsection{Kupluk berkucir}

Kupluk berkucir merupakan hiasan atas kepala dalam kesenian Babalu di Sanggar Putra Budaya. Seperti pada foto 4.47 adalah Kupluk Berkucir. 


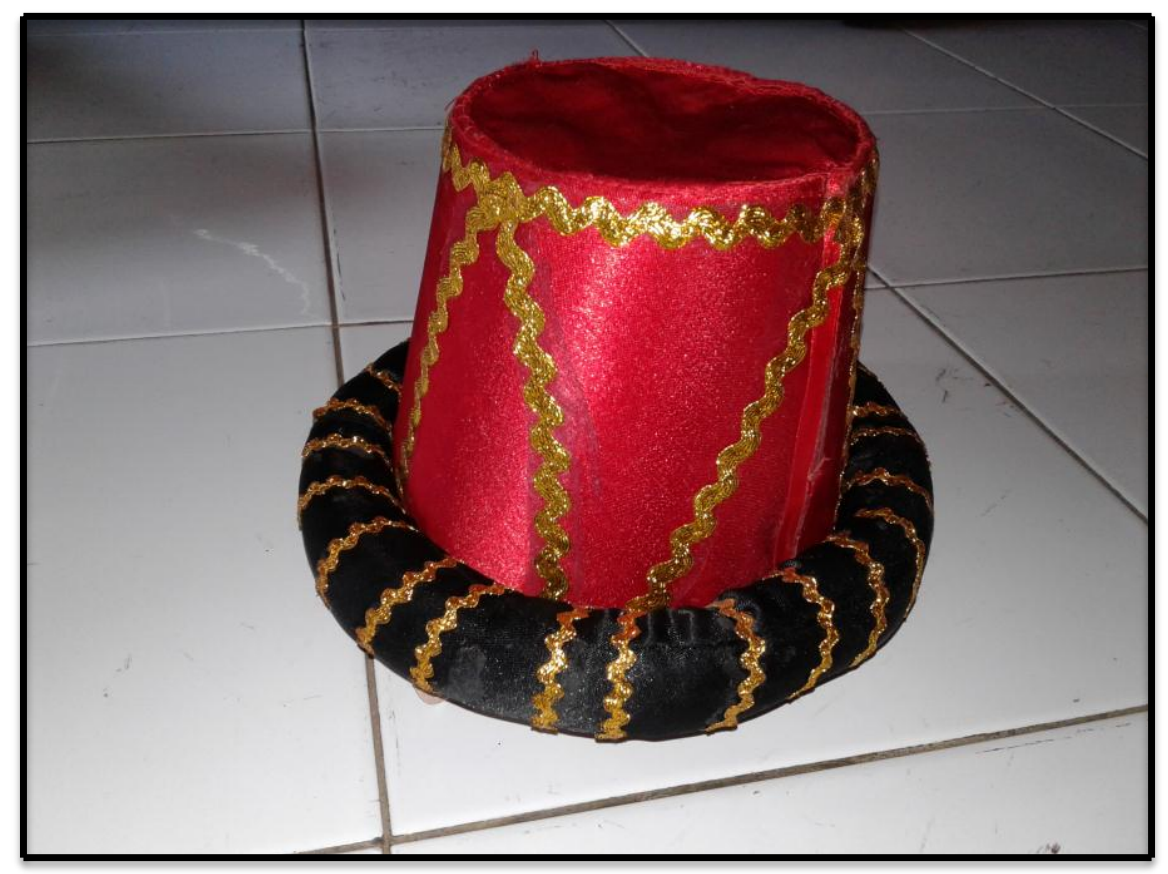

Foto 4.47 Kupluk Berkucir

(Sumber : Adilah endarini, 2 April 2017)

Pada Foto 4.47 adalah Kupluk Berkucir yang digunakan dalam kesenian Babalu di Kabupaten Batang mempunyai fungsi sebagai topi yang diletakkan diatas kepala dan menyimbolkan jiwa keberanian serta kegagahan seorang pejuang dalam memimpin pasukannya.

\subsubsection{Tata Suara}

Tata suara dalam Kesenian Babalu di Sanggar Putra Budaya Desa Proyonanggan Kabupaten Batang merupakan unsur pendukung dalam menunjang kegiatan pelatihan-pelatihan ataupun pertunjukan Kesenian Babalu. Tata Suara sangat penting untuk membantu agar suara yang dihasilkan oleh instrumen gamelan agar lebih bagus dan dapat didengar dengan baik meskipun dari jarak yang cukup jauh. 
Hal ini dimaksudkan untuk menarik penonton supaya berdatangan untuk menyaksikan jalannya pementasan. Dalam pertunjukan Kesenian Babalu untuk pemain alat musik menggunakan bantuan pengeras suara jika kondisi penonton ramai dan acaranya tergolong acara besar, namun jika dalam pertunjukan Kesenian Babalu hanya sebatas untuk pengenalan dan tidak dalam acara yang besar, pengeras suarapun tidak perlu diadakan karena bunyi alat musik sudah terdengar keras.

Posisi pengeras suara yang terdapat dalam pemain alat musik ataupun vokal yaitu pengeras suara dapat dipegang, diletakkan dilantai ataupun digantung. Lalu vokal dalam pertunjukan Kesenian Babalu juga menggunakan pengeras suara agar suara yang dihasilkan dapat terdengar lebih jelas oleh penonton. Hal ini juga memungkinkan jika tidak memakai pengeras suara, maka suara penyanyi akan tidak kedengaran karena tertutupi dengan suara musik yang keras, oleh karena itu peran pengeras suara sangat penting dalam pertunjukan maupun kegiatan pelatihan Kesenian Babalu.

\subsubsection{Tempat Pertunjukan}

Tempat pertunjukan merupakan sarana yang digunakan untuk melaksanakan suatu kegiatan atau pertunjukan baik secara indoor ataupun exdoor. Tempat pertunjukan tidak selalu memiliki pengertian panggung atau arena yang dipersiapkan khusus untuk pementasan. Halaman atau beranda rumah, pemantangan sawah, sepanjang jalan, lapangan dengan pohon atau peninggalan tertentu disekitarnya, dan pantai tidak jarang menjadi area penyajian atau prosesi pertunjukan khusus. Foto 4.48 adalah tempat pelatihan kesenian Babalu di Sanggar 
Putra Budaya tepatnya di pendopo kelurahan desa Proyonanggan Kabupaten Batang.

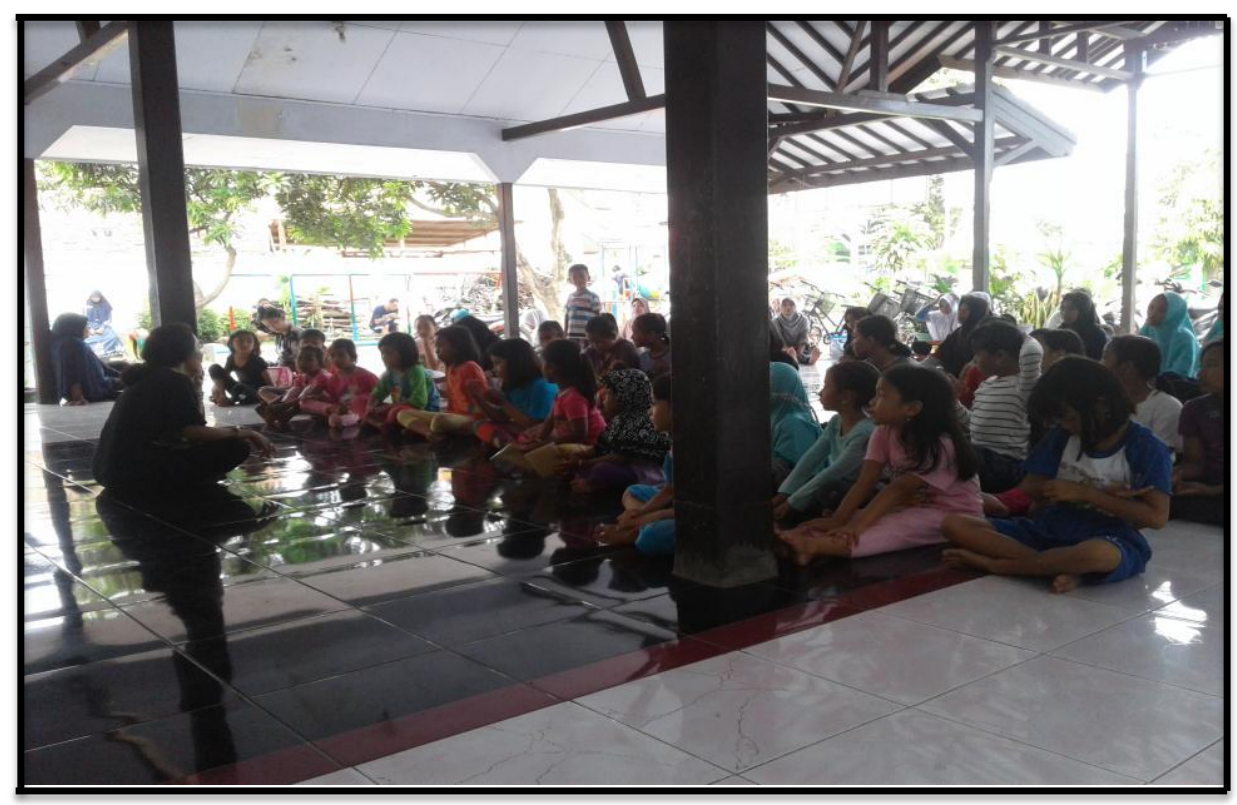

Foto 4.48 Pendopo Kelurahan Desa Proyonanggan

Sumber: Adilah Endarini, 2 April 2017

Pada foto 4.48 merupakan tempat pelatihan Kesenian Babalu yang bertempat di pendopo Kelurahan Desa Proyonanggan atau di Sanggar Putra Budaya Kabupaten Batang. Tempat tersebut selain untuk pelatihan kesenian Babalu namun juga dipakai untuk pementasan hasil pelatihan Sanggar oleh siswa-siswi Sanggar Putra Budaya.

Kesenian Babalu dilatihkan kepada siswa sanggar rutin setiap minggunya dan pernah dipertunjukan di Sanggar Putra Budaya sebagai hasil evaluasi sanggar, selain itu kesenian Babalu juga pernah dipertunjukkan di panggung, di lapangan dan di jalanan veteran alun-alun Batang. Tempat pertunjukan Kesenian Babalu 
tidak menentu, hal ini dikarenakan oleh kesesuaian kebutuhan dari penanggap Kesenian Babalu.

\subsubsection{Waktu Pementasan}

Waktu untuk pementasan Kesenian Babalu boleh di pentaskan di pagi hari, siang hari ataupun dimalam hari tergantung permintaan penanggap. Lalu untuk durasi pementasan Kesenian Babalu pada jaman dahulu sangat lama dan memakan waktu sekitar 2-3 jam disertai dengan dialog oleh pemain Kesenian Babalu, namun seiring berkembangnya jaman setelah diaktifkannya kembali Kesenian Babalu di Sanggar Putra Budaya pementasan dikemas menjadi lebih tertata dengan durasi pementasan yang persingkat menjadi kurang lebih 10 menit sesuai permintaan dari penanggap atau mengikuti susunan dalam suatu acara.

\subsubsection{Penonton.}

Penonton adalah seseorang yang menonton suatu pertunjukan yang menentukan berhasil tidaknya sebuah pertunjukan. Oleh karena itu penonton harus diperhitungkan dalam perencanaan penyajian suatu seni pendukung serta tingkat apresiasi masyarakat pada keberadaan seni pertunjukan.

Penonton dalam pertunjukan Kesenian Babalu sangat antusias dalam menikmati Kesenian Babalu dari awal pertunjukan sampai akhir pertunjukan. Penonton datang berbondong-bondong dari berbagai macam daerah di Kabupaten Batang datang hanya untuk melihat Kesenian Babalu. Seperti pada foto 4.49 antusisme penonton di acara pementasan Kesenian Babalu yang bertempat di Jalan Veteran Alun-alun Batang. 


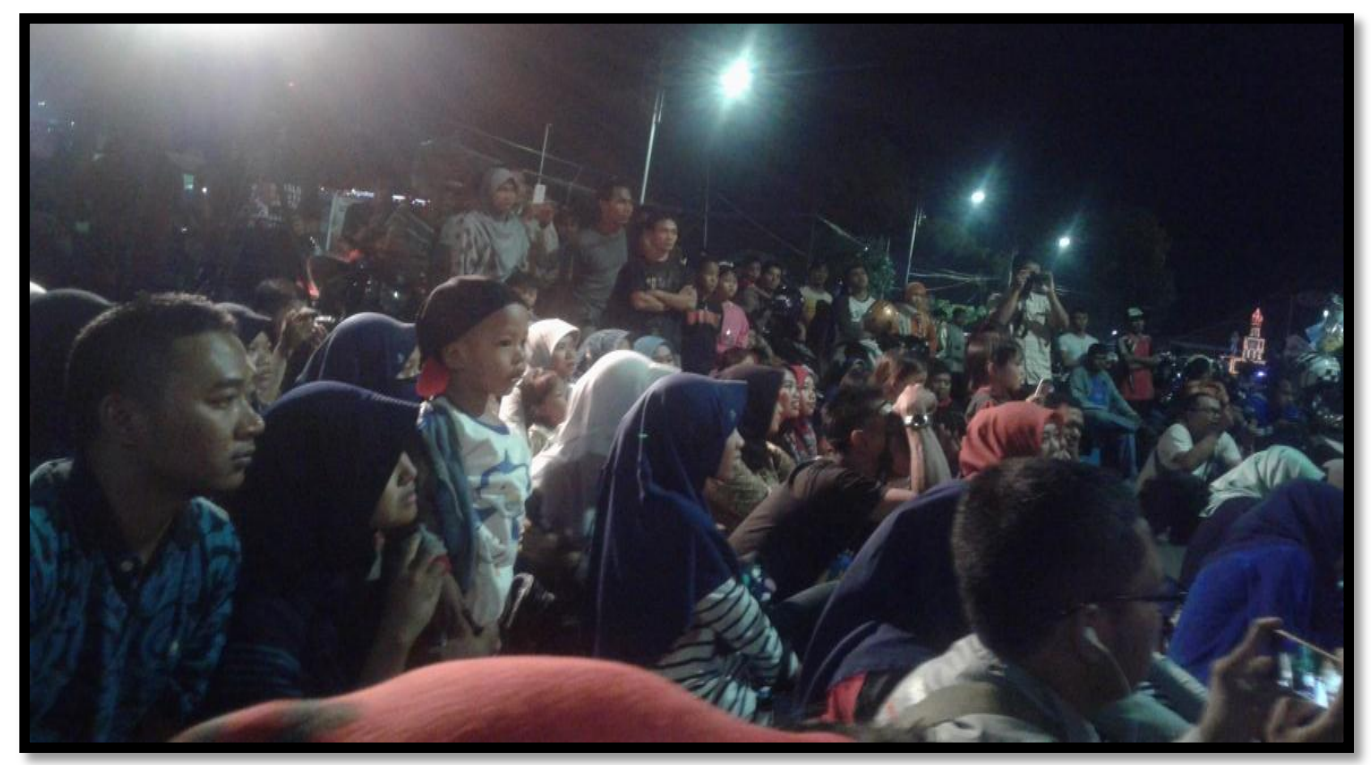

Foto 4.49 Penonton Kesenian Babalu Sumber: Adilah Endarini, 30 Agustus 2016

Pada foto 4.49 merupakan kondisi masyarakat dalam menonton kesenian Babalu yang di pentaskan malam hari tanggal 30 Agustus 2016 di Jalan Veteran Alun-alun Batang. Penonton Kesenian Babalu terdiri dari berbagai golongan umur, baik anak-anak, remaja, dewasa dan juga orang tua.

\subsection{Pelestarian Kesenian Babalu di Sanggar Putra Budaya Desa Proyonanggan Kabupaten Batang}

Pelestarian Kesenian Babalu di Sanggar Putra Budaya Desa Proyonanggan Kabupaten Batang peneliti menggunakan teori Edi Sedyawati (2008 : 209) bahwa kesenian harus dijaga agar keseimbangan senantiasa dipertahankan antara keberlanjutan dan perubahan yang sedemikian rupa agar jati diri bangsa atau suku bangsa senantiasa tampil dengan jelas dan tidak ditenggelamkan oleh pengaruhpengaruh asing tertentu. 
Kesenian Babalu merupakan kesenian kerakyatan yang dikembangkan di Sanggar Putra Budaya. Sanggar Putra Budaya sebagai organisasi yang bergerak dibidang kesenian berupaya untuk memiliki peranan terhadap perkembangan Kesenian khususnya Kesenian Babalu asal Kabupaten Batang melalui pelatihanpelatihan dan pementasan-pementasan tari. Bedasarkan teori Sedyawati (2008: 152) pelestarian dilihat sebagai sesuatu yang terdiri dari tiga aspek, yaitu (1) perlindungan, (2) pemanfaatan dan (3) pengembangan. Maka peneliti akan membahas pelestarian Kesenian Babalu di Sanggar Putra Budaya sesuai dengan teori Edi Sedyawati (2008:152) yaitu :

\subsubsection{Perlindungan}

Perlindungan Kesenian Babalu adalah suatu usaha yang dilakukan untuk menjaga suatu kesenian agar keberadaannya tetap dapat dinikmati oleh masyarakat. Perlindungan Kesenian Babalu di Sanggar Putra Budaya dilakukan salah satunya melalui pelatihan tari yang diadakan di Sanggar Putra Budaya Desa Proyonanggan Kabupaten Batang. Berikut penjelasan mengenai kegiatan pelatihan tari yang dilakukan di Sanggar Putra Budaya.

\subsubsection{Pelatihan Tari di Sanggar Putra Budaya Desa Proyonanggan}

\section{Kabupaten Batang.}

Upaya perlindungan kesenian Babalu dilakukan dengan pelatihan-pelatihan tari di Sanggar Putra Budaya Desa Proyonanggan Kabupaten Batang. Pelatihan tari dilakukan dengan menjadikan Kesenian Babalu sebagai materi wajib dalam pelatihan tari. Sistem awal latihan yaitu siswa lama yang sudah mahir menarikan 
Kesenian Babalu berada pada barisan paling depan dan kemudian diikuti dengan siswa baru ataupun siswa yang belum hafal Kesenian Babalu.

Bedasarkan wawancara dengan Ibu suningsih (2 April 2017) selaku pelatih Kesenian Babalu mengatakan sebagai berikut :

“...Kesenian Babalu harus dibiasakan ditarikan dulu sebelum masuk ke materi wajib mbak, hal ini saya lakukan supaya anak-anak selalu ingat dan menghafal gerakan dalam kesenian Babalu..."

Kebiasaan menarikan Kesenian Babalu sebagai materi wajib sebelum ke materi pokok Sanggar Putra Budaya diharapkan agar Kesenian Babalu dapat dilestarikan terus-menerus kepada siswa di Sanggar Putra Budaya yang merupakan pusat terciptanya Kesenian Babalu (Wawancara Suningsih 2 April 2017).

Sanggar Putra Budaya memberikan pelatihan tari setiap hari minggu jam 09:00-11:00 yang dibagi menjadi tiga kelas yaitu kelas dasar, lanjut dan kelas mahir, materi yang diberikan pada pelatihan tari meliputi Kesenian Babalu, Tari Molek, Tari Kelinci, Tari Kukilo dan Tari Gambyong. Untuk materi dasar dalam pelatihan tari yaitu Kesenian Babalu, siswa yang belum hafal Kesenian Babalu masuk ke dalam kelas dasar selama kurang lebih 3 bulan. Setelah hafal Kesenian Babalu siswa dapat memperoleh materi lain yang telah ditentukan oleh pelatih contoh Tari Molek, Tari Kelinci dan Tari Kukilo. Untuk kelas mahir yaitu siswa yang sudah benar-benar mahir dalam menari dan akan diberikan materi tari klasik seperti Tari Gambyong dan Tari Kreasi baru. Berikut merupakan foto kegiatan pelatihan Kesenian Babalu di Sanggar Putra Budaya Desa Proyonanggan Kabupaten Batang. Seperti pada foto 4.50 berikut. 


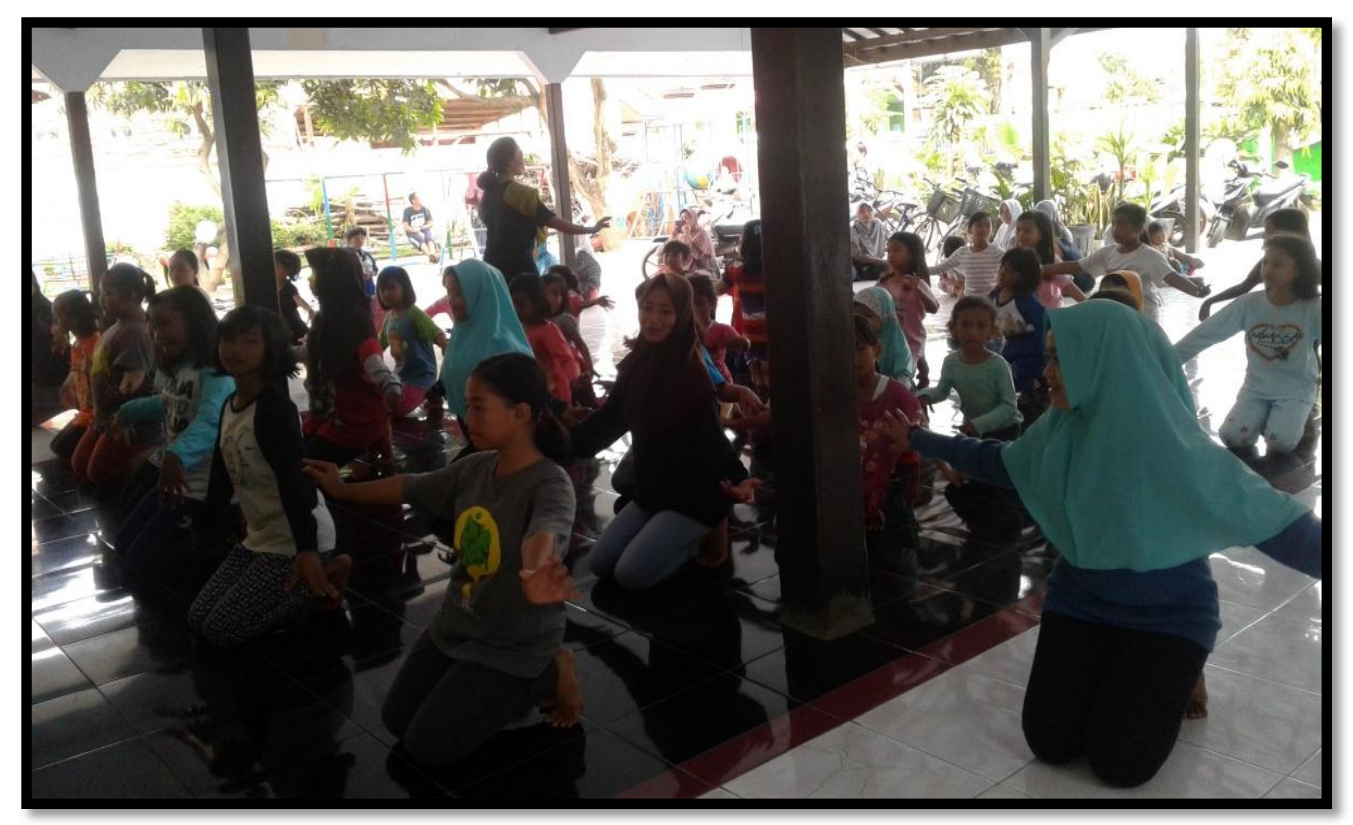

Foto 4.50 Pelatihan Kesenian Babalu

Sumber : Adilah Endarini, 2 April 2017

Pada foto 4.50 merupakan kegiatan pelatihan Kesenian Babalu yang diadakan pada hari Minggu tanggal 2 April 2017 pukul 09.00 sampai pukul 11.00. Antusias anak-anak dalam mempelajari gerakan dalam Kesenian Babalu membuat keberadaan Kesenian Babalu akan selalu terjaga. Pelatihan tari dilakukan di Sanggar Putra Budaya atau di Pendopo Kelurahan Desa Proyonanggan Tengah. Sanggar Putra Budaya memiliki siswa kurang lebih ada 50 orang, namun terkadang semakin banyak dan kadang semakin sedikit

Pelatihan tari di Sanggar Putra Budaya dimulai dari salam lalu berdoa bersama kemudian pemanasan badan terlebih dahulu lalu menarikan materi wajib yaitu tari Babalu dan menarikan tarian yang menjadi pokok dalam materi. Selain masyarakat Kabupaten Batang, Mahasiswa Universitas Negeri Semarang juga datang untuk mengikuti kegiatan pelatihan Kesenian Babalu di Sanggar Putra 
Budaya, Berikut foto 4.51 adalah kegiatan pelatihan Kesenian Babalu oleh Sanggar Putra Budaya kepada mahasiswa seni tari UNNES.

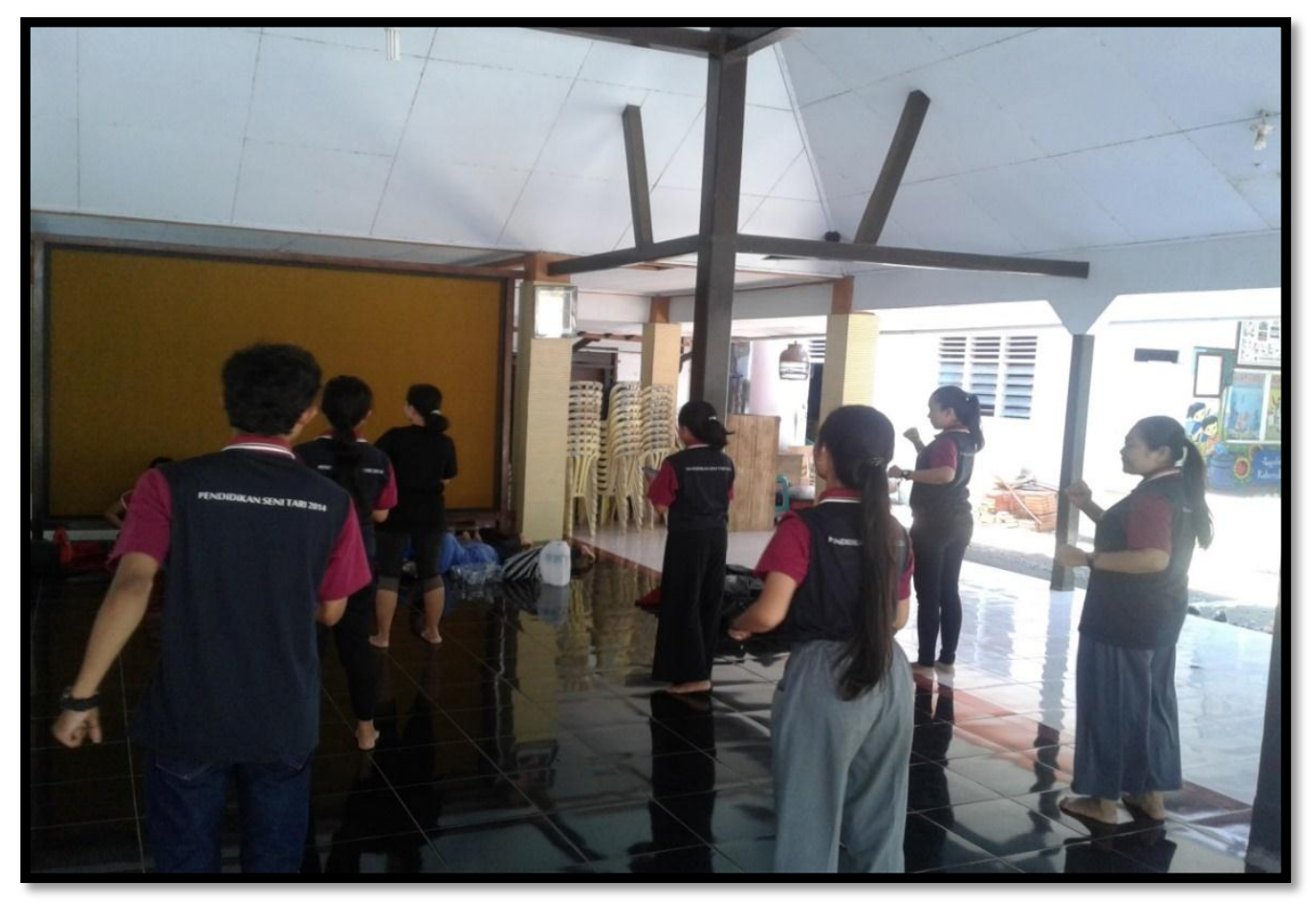

Foto 4.51 Pelatihan Kesenian Babalu di Sanggar Putra Budaya Sumber : Adilah Endarini, 18 September 2016

Pada Foto 4.51 merupakan kegiatan pelatihan gerak Kesenian Babalu pada tanggal 18 September 2016 di Sanggar Putra Budaya yang dilatih oleh Ibu Suningsih selaku Sie Kepelatihan Sanggar kepada Mahasiswa Seni Tari Unnes yang sedang melakukan kegiatan pembelajaran Kesenian Babalu guna memenuhi hasil akhir mata kuliah Tari Jateng. Selain itu kesenian Babalu juga dilatihkan kepada siswa-siswi sekolah-sekolah di Kabupaten Batang, hal ini dilakukan agar generasi muda diberi ilmu pengetahuan tentang kesenian Babalu sejak dini agar mereka ikut turut bangga akan keberadaan kesenian Babalu dan ikut turut melestarikan Kesenian Babalu. Seperti pada foto 4.52 berikut ini 


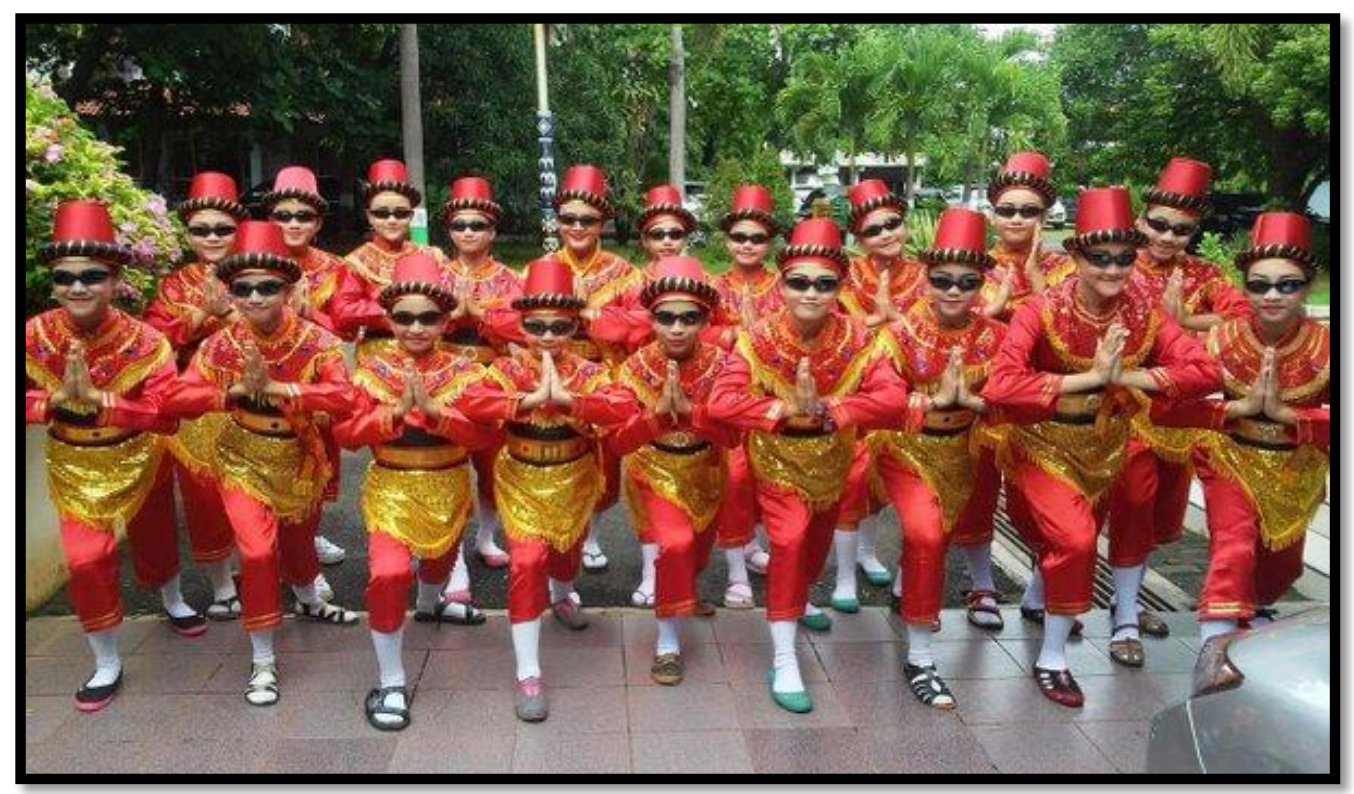

Foto 4.52 Pementasan Kesenian Babalu oleh Siswa SMP Sumber : Adilah Endarini, 2016

Foto 4.52 merupakan pementasan Kesenian Babalu di acara POPDA Tingkat Kabupaten Batang pada tahun 2016. Acara tersebut dihadiri oleh Bapak Yoyok Sudibyo selaku Mantan Bupati Batang dan Bapak Ganjar Pranowo selaku Gubernur Jawa Tengah. Para Penari yang menarikan Kesenian Babalu merupakan siswa SMPN 3 Batang dan siswa SMPN 6 Batang. Hal tersebut menunjukan bahwa Kesenian Babalu di latihkan selain di dalam ruang lingkup Sanggar Putra Budaya namun juga di pentaskan secara ekstern melalui sekolah-sekolah.

\subsubsection{Pemanfaatan}

Pemanfaatan Kesenian Babalu di Sanggar Putra Budaya merupakan usaha memperkenalkan Kesenian Babalu kepada masyarakat luas bahwa kesenian Babalu merupakan kesenian yang harus dijaga keberadaannya. Salah satu usaha pemanfaatan Kesenian Babalu yaitu melalui pementasan-pementasan Kesenian 
Babalu kepada masyarakat baik di sekitar Kabupaten Batang maupun di sekitar luar Kabupaten Batang, pementasan-pementasan juga dilakukan baik dari dalam sanggar maupun dari luar Sanggar Putra Budaya Desa Proyonanggan Kabupaten Batang. Hal ini dapat membuat masyarakat yang belum tahu sanggar Putra budaya dan Kesenian Babalu dapat mengetahui melalui pementasan-pementasan kesenian Babalu.

\subsubsection{Pementasan-pementasan Kesenian Babalu}

Sanggar Putra Budaya melestarikan Kesenian Babalu di Kabupaten Batang melalui upaya pemanfaatan Kesenian Babalu yaitu salah satunya dilakukan melalui pementasan-pementasan Kesenian Babalu. Pementasan Kesenian Babalu di dipentaskan pada acara-acara di wilayah Kabupaten Batang ataupun di luar Kabupaten Batang yang menjadikan masyarakat Batang dan di luar Kabupaten Batang semakin mengenal Kesenian Babalu sebagai Kesenian khas Kabupaten Batang. Pementasan yang dilaksanakan Sanggar Putra Budaya terbagi dalam dua jenis yaitu pementasan dari dalam sanggar dan dari luar sanggar.

Pementasan dari dalam sanggar yaitu pementasan untuk kepentingan sanggar. Misalnya evaluasi sanggar, yaitu pementasan dalam rangka ujian atau evaluasi bagi siswa di Sanggar Putra Budaya. Pementasan ini bisa menjadi sarana untuk mengenalkan serta menyebarluaskan Kesenian Babalu terhadap masyarakat sekaligus bisa dijadikan sarana hiburan bagi masyarakat. Kegiatan ini berguna untuk mengevaluasi siswa dan mengetahui kemampuan siswa sejauhmana pemahaman siswa terhadap materi yang sudah di berikan oleh pelatih sanggar, dan dengan adanya evaluasi, pelatih juga dapat belajar mengetahui kekurangan pelatih 
dalam proses pelatihan untuk memperbaiki cara dalam mengajarkan pelatihan tari yang lebih baik.

Pementasan dari luar sanggar yaitu pementasan yang dilaksanakan diluar sanggar untuk kepentingan acara tertentu. Sanggar Putra Budaya melaksanakan pementasan Kesenian Babalu untuk mengisi acara yang dilaksanakan oleh pemerintah Kabupaten Batang ataupun untuk tanggapan dan perayaan Hari Jadi Kabupaten Batang. Berikut dokumentasi pementasan Kesenian Babalu di acara syukuran Bupati dan Wakil Bupati terpilih di Gedung wanita Kabupaten Batang pada tanggal 12 Maret 2017. Seperti pada foto 4.53 berikut :

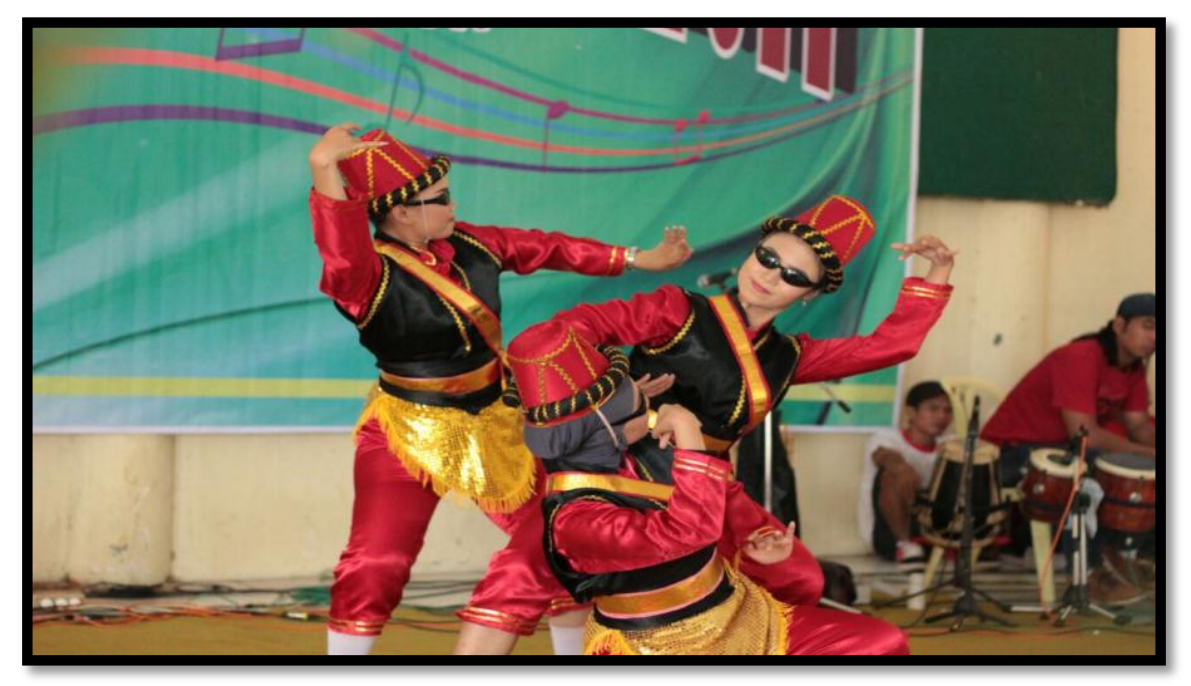

Foto 4.53 Pementasan Kesenian Babalu Sumber : Adilah Endarini, 12 Maret 2017

Foto 4.53 merupakan pementasan kesenian Babalu di Gedung Wanita Kabupaten Batang, Selain itu sanggar putra budaya juga mementaskan Kesenian Babalu diluar ruangan tertutup untuk didokumentasikan sebagai koleksi sanggar serta sebagai proses usaha pematenan kesenian Babalu menjadi kesenian asli dari 
Kabupaten Batang pada bulan Juli 2016 yang bekerja sama dengan siswa Sanggar dan pemerintah Kabupaten Batang.

Berikut merupakan dokumentasi proses rekaman video Kesenian Babalu yang ditarikan oleh 4 penari wanita dengan gerakan enerjik serta penuh semangat. Pementasan Kesenian Babalu dilakukan pada bulan juli tahun 2016 di halaman gazebo luar gedung wanita Kabupaten Batang dengan menggunakan alat musik secara live yang terdiri dari Kendhang, Kentungan, Rebana, Kenong, Kempul Bonang, dan Gong. Seperti pada foto 4.54 berikut

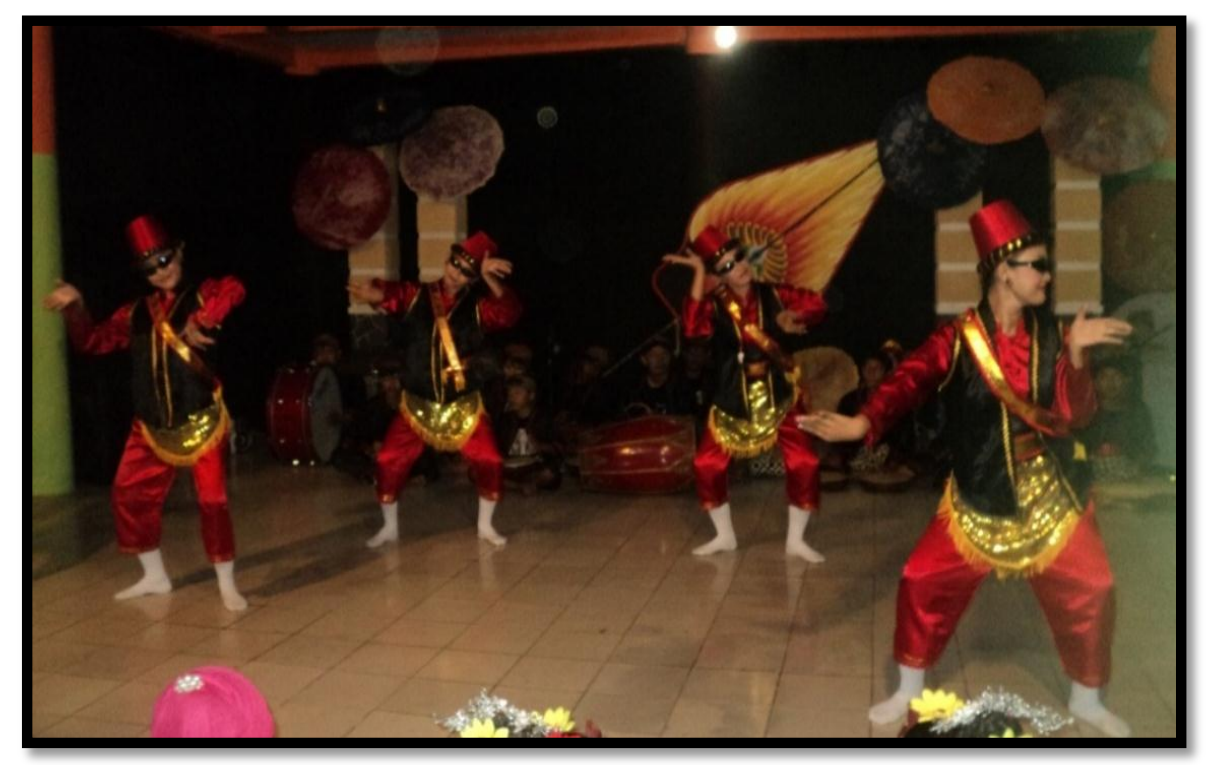

Foto 4.54 Proses Rekaman Video Kesenian Babalu Oleh Sanggar Putra Budaya Sumber: Dokumen pribadi Sanggar Putra Budaya, Juli 2016

Pada foto 4.54 berupa proses rekaman pembuatan video Kesenian Babalu yang bertujuan sebagai proses usaha pematenan Kesenian Babalu agar menjadi Kesenian resmi yang berasal dari Kabupaten Batang. Proses pembuatan video 
dilaksanakan di depan Gedung Wanita Kabupaten Batang pada malam hari dengan iringan musik live.

Selain itu Sanggar Putra Budaya juga melakukan pementasan Kesenian Babalu untuk mengisi acara-acara yang dilaksanakan oleh pihak pemerintah di Kabupaten Batang ataupun dari organisasi-organisasi lain serta tanggapantanggapan masyarakat baik di wilayah Kabupaten Batang maupun dari luar Kabupaten Batang. Berikut dokumentasi berupa foto pementasan Kesenian Babalu dengan instrumen musik secara live yang dilaksanakan di pelataran Alun-alun Kabupaten Batang untuk perayaan hari TNI Nasional pada tanggal 5 oktober 2016. Seperti pada foto 4.55 berikut :

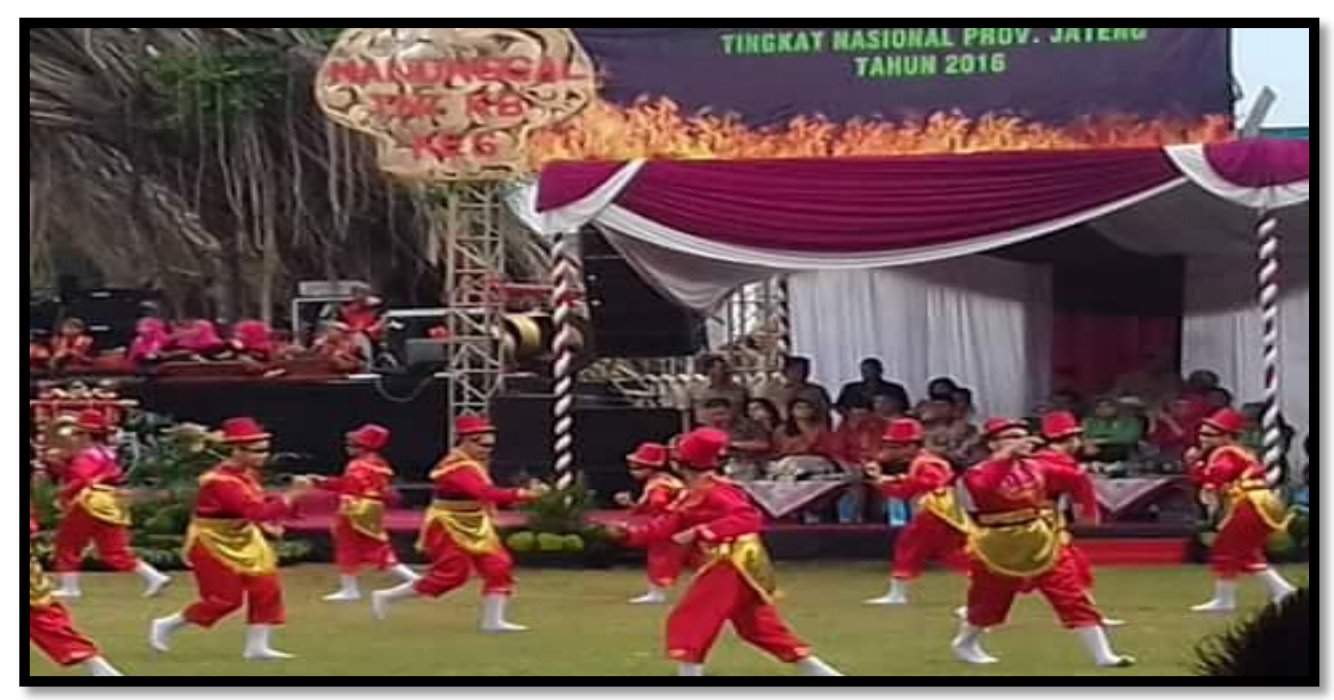

Foto 4.55 Hari TNI Nasional di Alun-alun Batang Sumber: Dokumen pribadi Sanggar Putra Budaya, 5 Oktober 2016

Pada Foto 4.55 Sanggar Putra Budaya menampilkan Kesenian Babalu dalam jumlah masal sekitar 30 orang penari dan jumlah pemusik sekitar 10 orang. Pementasan Kesenian Babalu dilakukan dengan penempatan pemusik berada atas 
panggung dan penari berada di bawah panggung dikarenakan jumlah pemain yang banyak dan membutuhkan tempat yang cukup luas. Pementasan Kesenian Babalu dilakukan agar Kesenian Babalu dapat dikenal oleh masyarakat di Kabupaten Batang ataupun di Luar Kabupaten Batang.

Pementasan Kesenian Babalu oleh Sanggar Putra Budaya selanjutnya dibawakan oleh para penari Sanggar Putra Budaya pada acara Pameran Lukisan dan Pentas Kesenian Tradisional yang dilaksanakan di Jogjakarta pada bulan April 2013 dengan jumlah penari ada 6 orang dan jumlah pemusik 10 orang. Berikut foto 4.56 merupakan dokumentasi berupa foto siswa Sanggar Putra Budaya setelah selesai pementasan :

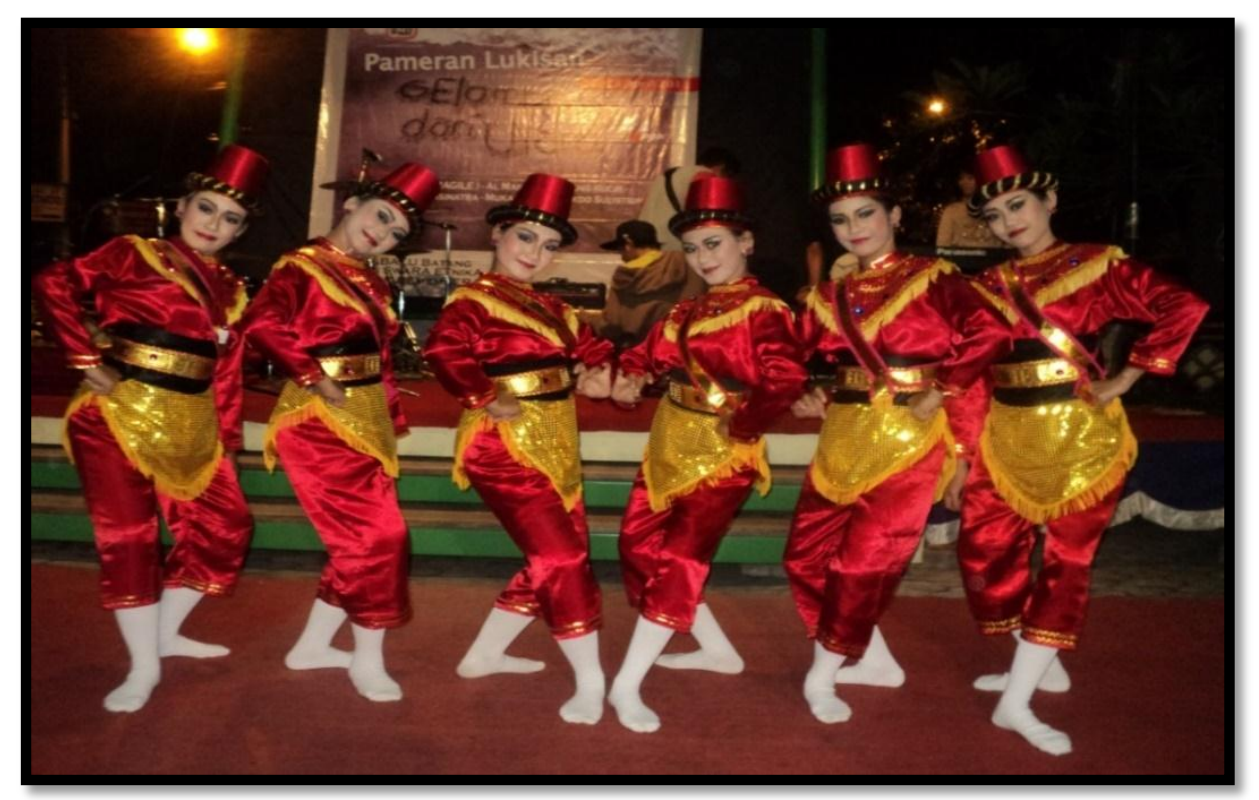

Foto 4.56 Pameran dan Pentas Seni Tradisi di Jogja Sumber: Dokumen Pribadi Sanggar Putra Budaya, April 2017

Pementasan selanjutnya yaitu pementasan Kesenian Babalu oleh Sanggar Putra Budaya Kabupaten Batang yang dipentaskan untuk meramaikan acara 
Festival Kesenian Kerakyatan yang bertempat di Kota Bandung pada bulan September 2016. Sanggar Putra Budaya mengirimkan perwakilan pemain Kesenian Babalu berjumlah 12 orang pemain yang terdiri dari penari dan pemusik Kesenian Babalu. Penari yang menarikan kesenian Babalu di Bandung berjumlah dua yang merupakan seorang pelatih tari Sanggar Putra Budaya. Seperti pada foto 4.57 berikut :

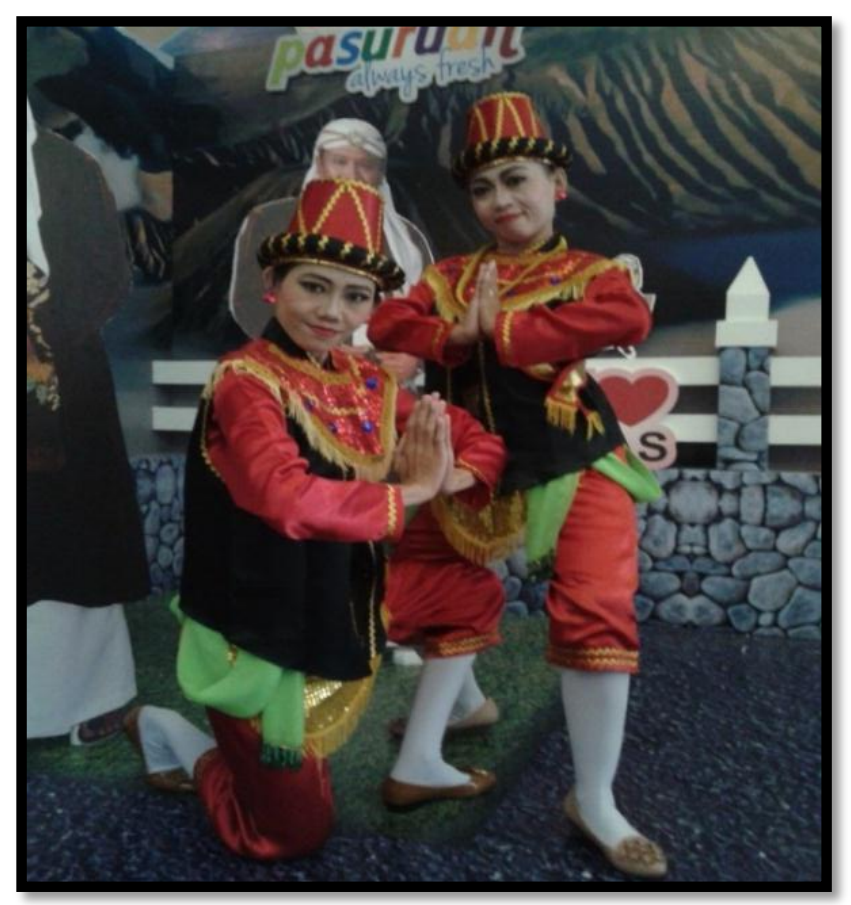

Foto 4.57 Festival Seni Kerakyatan di Bandung Sumber: Dokumen Pribadi Sanggar Putra Budaya, September 2016.

Foto 4.57 merupakan salah satu pementasan-pementasan dilakukan oleh Sanggar Putra Budaya sebagai suatu usaha penyebarluasan Kesenian Babalu agar dapat semakin dikenal di masyarakat Kabupaten Batang ataupun diluar Kabupaten Batang, usaha-usaha penyebarluasan masyarakat dalam melestarikan Kesenian Babalu yaitu Guru Seni Budaya dan para pelaku seni di Kabupaten 
Batang mengadakan seminar dan memasukan materi tari Babalu dalam mata pelajaran seni budaya, orang yang sangat berperan dalam usaha penyebarluasan Kesenian Babalu yaitu Bapak Suprayetno, ibu Suningsih selaku pelatih kesenian Babalu, guru seni budaya di Kabupaten Batang dan para pelaku seni di wilayah Kabupaten Batang.

Pementasan-pementasan dilakukan oleh Sanggar bekerjasama dengan Pemerintah Batang, beberapa contoh kerjasama sanggar dan pemerintah yaitu Sanggar Putra Budaya membawakan Kesenian Babalu di acara Sosialisasi Pilkada Tingkat Nasional di Hotel Sahid Mandarin Pekalongan pada tanggal 23 September tahun 2016 lalu tampil di acara Inbox SCTV yang bertempat di Alunalun Batang pada tahun 2016.

Kesenian Babalu juga tampil di INDOSIAR pada acara Bintang Pantura pada tahun 2016 dan tampil di acara hari TNI Nasional Provinsi Jawa Tengah yang bertempat di Alun-alun Batang pada tanggal 5 Oktober 2016 dengan melibatkan penari Babalu massal 50 orang serta tamu undangan yang dihadiri oleh Bupati Batang beserta jajarannya dan Tentara Nasional Indonesia yang datang dari berbagai wilayah. Hal ini menujukan bahwa Usaha Pelestarian Kesenian Babalu didukung oleh Pemerintah Kabupaten Batang, Para pelaku seni di Batang serta Beberapa masyarakat Kabupaten Batang.

Berikut merupakan foto 4.58 Pementasan Kesenian Babalu dari Sanggar Putra Budaya Desa Proyonanggan Kabupaten Batang di acara INBOX SCTV 
yang ditampilkan dengan iringan musik secara live dengan penari massal yang berjumlah 15 orang dan terdiri dari berbagai golongan umur yang berbeda-beda.

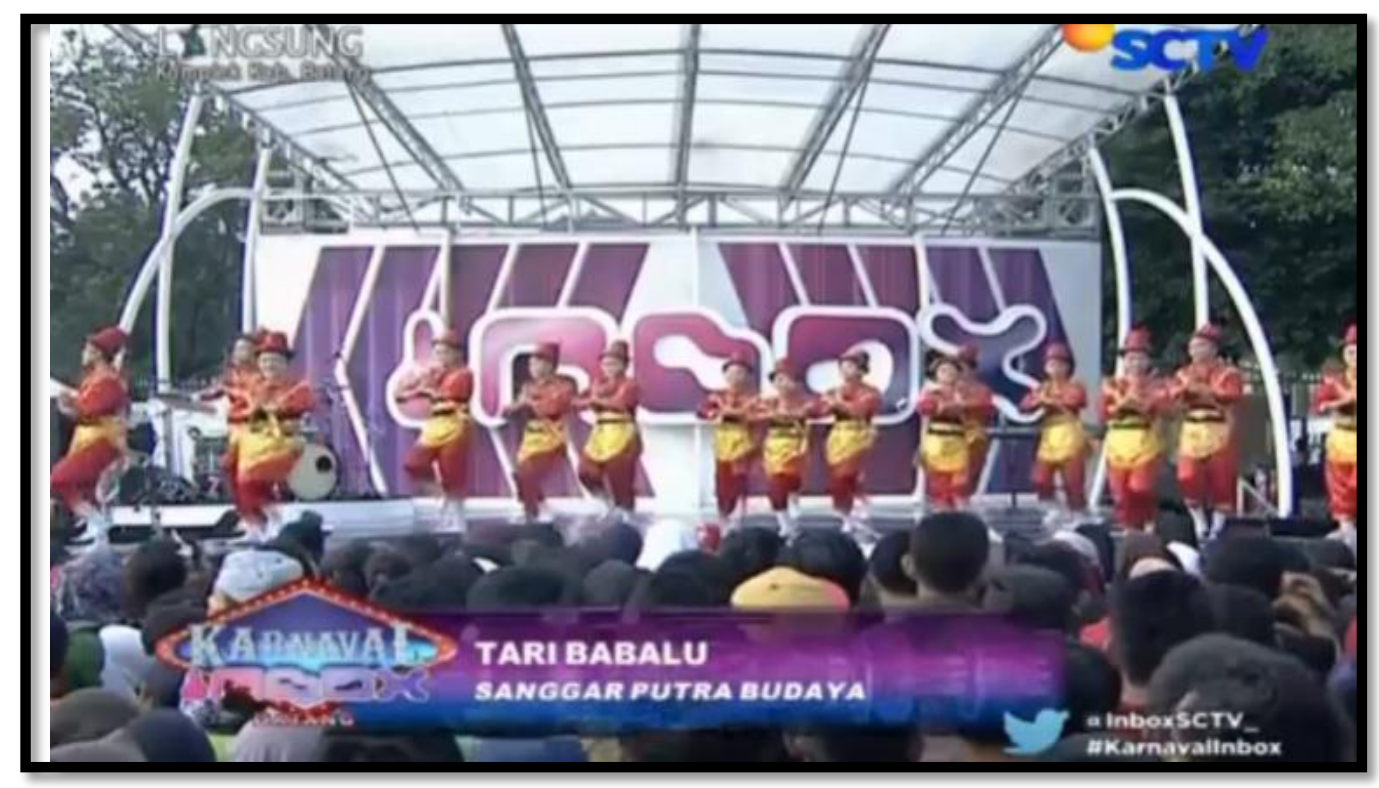

Foto 4.58 Pementasan Kesenian Babalu INBOX SCTV Sumber : Adilah Endarini, 23 September 2016

Foto 4.58 merupakan pementasan Kesenian Babalu diacara INBOX SCTV pada tanggal 23 September 2016 yang bertempat di halaman depan Pendopo Kabupaten Batang yang berada disekitar di Jalan Veteran Alun-alun Batang. Pementasan Kesenian Babalu di INBOX merupakan kerjasama Sanggar Putra Budaya dengan Pemerintahan Kabupaten Batang. Hal ini dilakukan sebagai Pelestarian Kesenian Babalu dengan usaha penyebarluasan agar masyarakat baik di Kabupaten Batang maupun diluar Kabupaten Batang dapat mengetahui bahwa Kesenian Babalu merupakan Kesenian Khas yang berasal dari Kabupaten Batang. 
Selain pementasan di acara INBOX SCTV, berikut merupakan pementasan Kesenian Babalu yang diadakan diacara Festival Pertunjukan Rakyat Nasional yang bertempat di Kota Bandung:

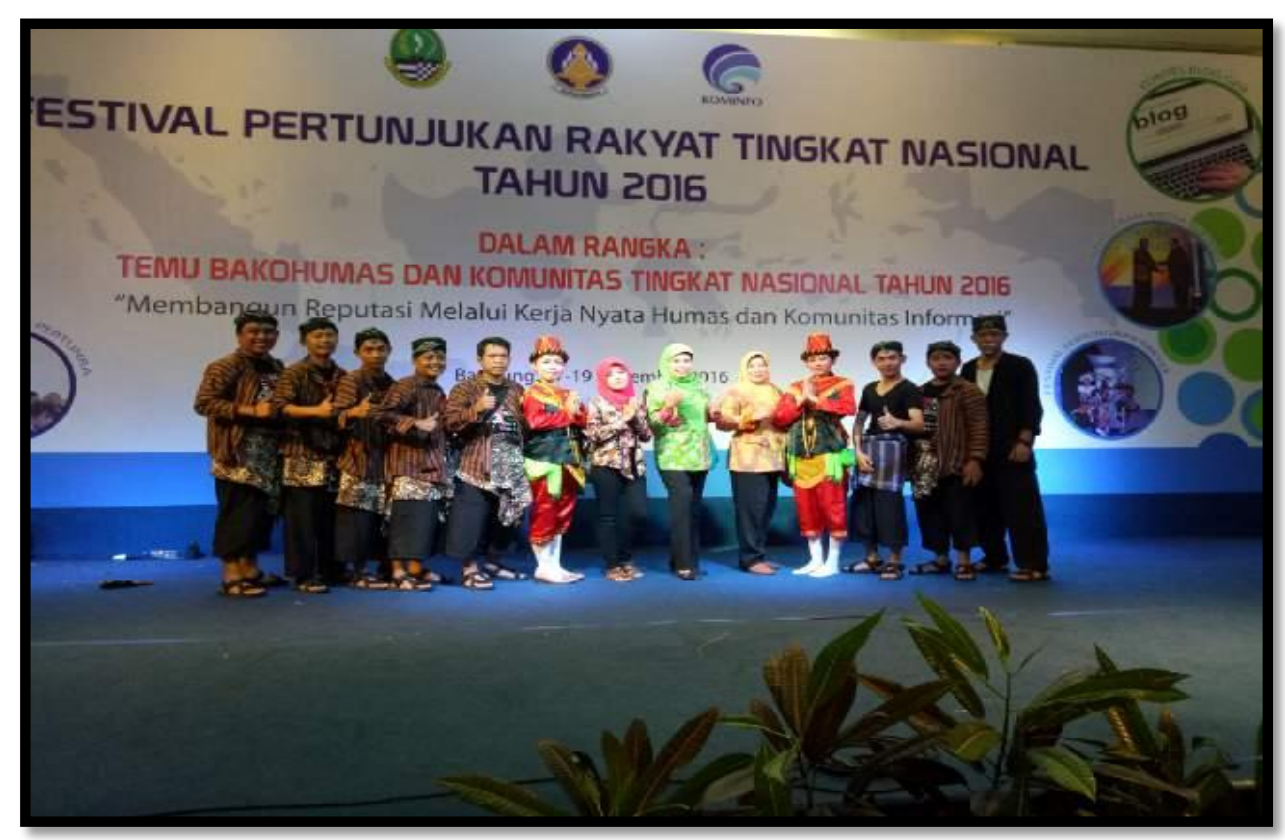

Foto 4.59 Pementasan Babalu di Festival Pertunjukan Rakyat Nasional Sumber : Adilah Endarini, 19 September 2016

Foto 4.59 merupakan pemusik dan penari dalam pementasan Kesenian Babalu yang diadakan pada acara Festival Pertunjukan Rakyat Tingkat Nasional pada tanggal 19 september tahun 2016 dalam rangka temu bakohumas dan komunitas tingkat nasional di Bandung. Pada pertunjukan tersebut penari Babalu hanya berjumlah 2 orang dan pemusik berjumlah 8 orang.

Berikut foto 4.60 merupakan Kegiatan Sanggar Putra Budaya Desa Proyonanggan Kabupaten Batang dalam pementasan Kesenian Babalu yang diadakan diacara Festival Badan Usaha Milik Desa yang bertempat di Alun-alun Kabupaten Batang Jawa Tengah. 


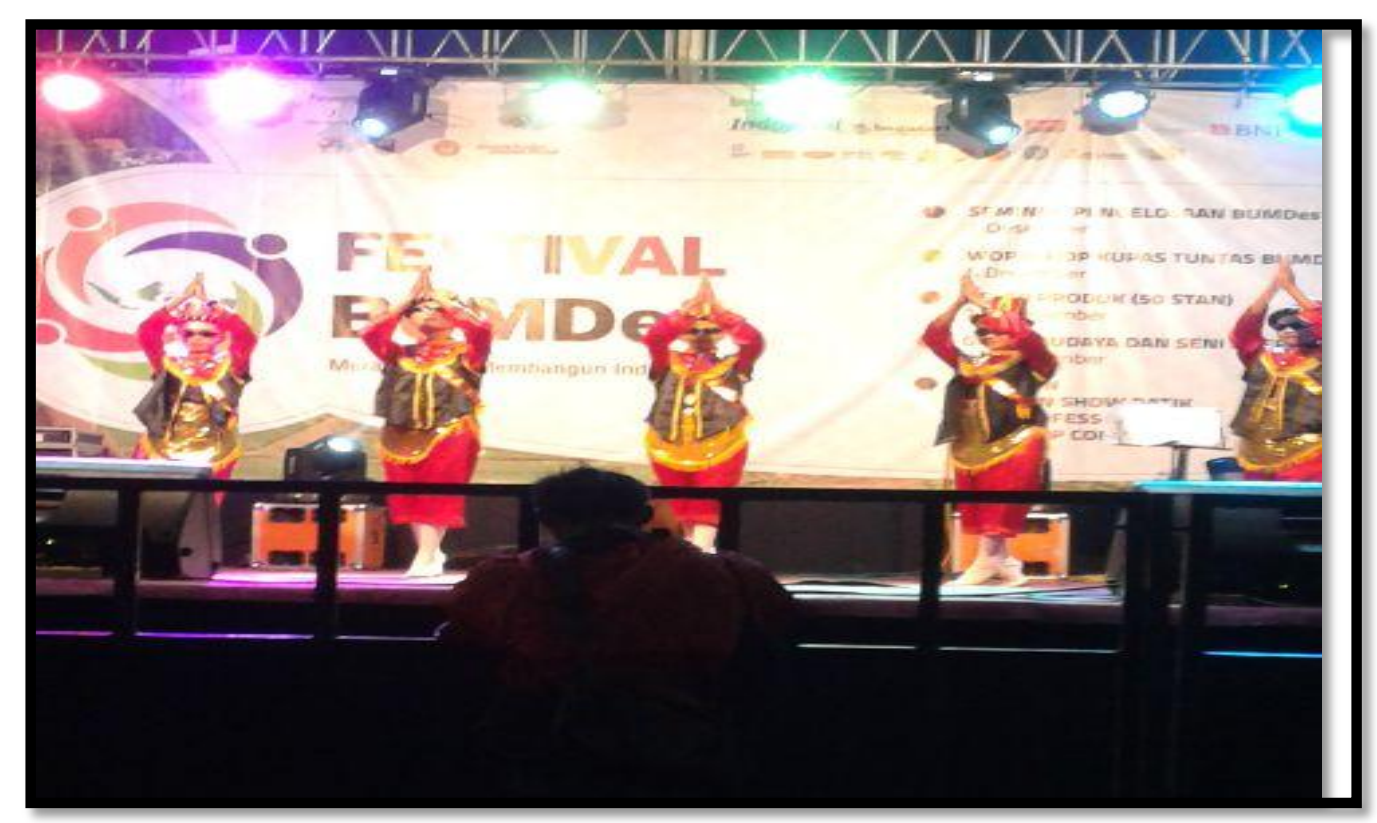

Foto 4.60 Pementasan Kesenian Babalu BumDes Sumber : Adilah Endarini, Maret 2016

Pada Foto 4.60 berupa pementasan Kesenian Babalu yang dilaksanakan di Kabupaten Batang pada acara Festival BUMDes (Festival Badan Usaha Milik Desa) bulan Maret 2016. Penari yang menarikan Kesenian Babalu berjumlah 5 orang yang merupakan siswa Sanggar Putra Budaya.

Selain melalui Sanggar Putra Budaya Kesenian Babalu juga di pentaskan oleh masyarakat yang tergabung dalam organisasi-organisasi tertentu. Salah satunya yaitu Organisasi FORKOMBI (Forum Komunitas Mahasiswa Batang Indonesia) yang menampilkan perwakilan anggotanya untuk menampilkan Kesenian Babalu pada peringatan Hari Sumpah Pemuda tanggal 28 Oktober 2016 yang bertempat di Pendopo Kabupaten Batang. Berikut foto 4.61 merupakan mahasiswa yang tergabung dalam Organisasi Forkombi saat selesai menarikan Kesenian Babalu : 


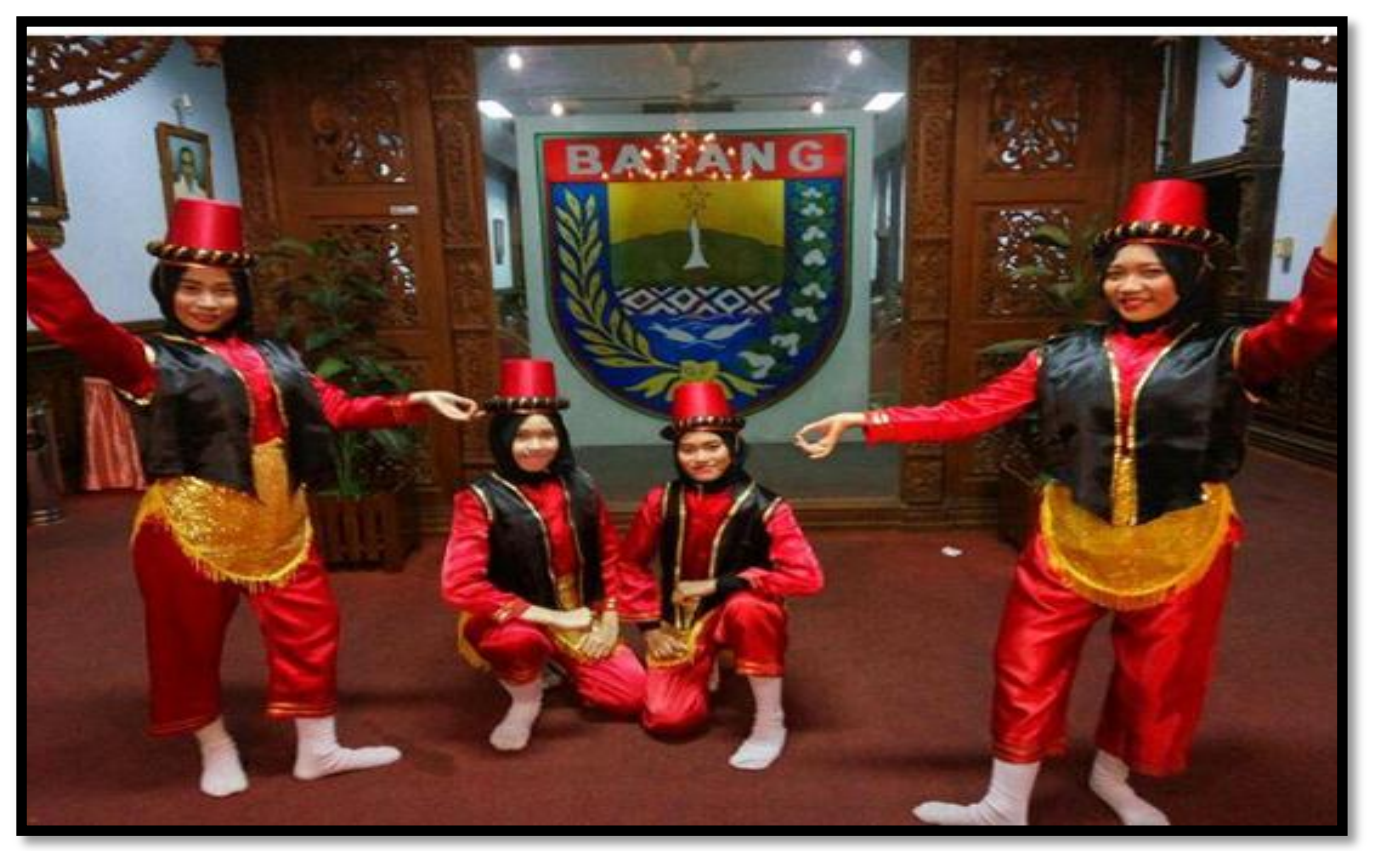

Foto 4.61 Mahasiswa Forkombi Usai Menarikan Kesenian Babalu Sumber : Adilah Endarini, 8 Juli 2016

Foto 4.61 merupakan 4 penari perwakilan mahasiswa FORKOMBI (Forum Komunitas Mahasiswa Batang Indonesia) setelah selesai menarikan Kesenian Babalu asal Kabupaten Batang pada tanggal 28 Oktober 2016 untuk memperingati Hari Sumpah Pemuda yang bertempat di belakang Pendopo Kabupaten Batang. Selain dari Forkombi terdapat Organisasi Seni yang turut serta dalam melestarikan Kesenian Babalu di wilayah luar dari Kabupaten Batang yaitu Sanggar Puspo Budoyo Semarang. Sanggar Puspo Budoyo mengirim perwakilan anggotanya untuk menampilkan kesenian Babalu di acara PKRJT (Pekan Kesenian Rakyat Jawa Tengah) yang diadakan di halaman Kota Lama Semarang. Berikut foto 4.62 adalah pementasan Kesenian Babalu dari Sanggar Puspo Budoyo Semarang. 


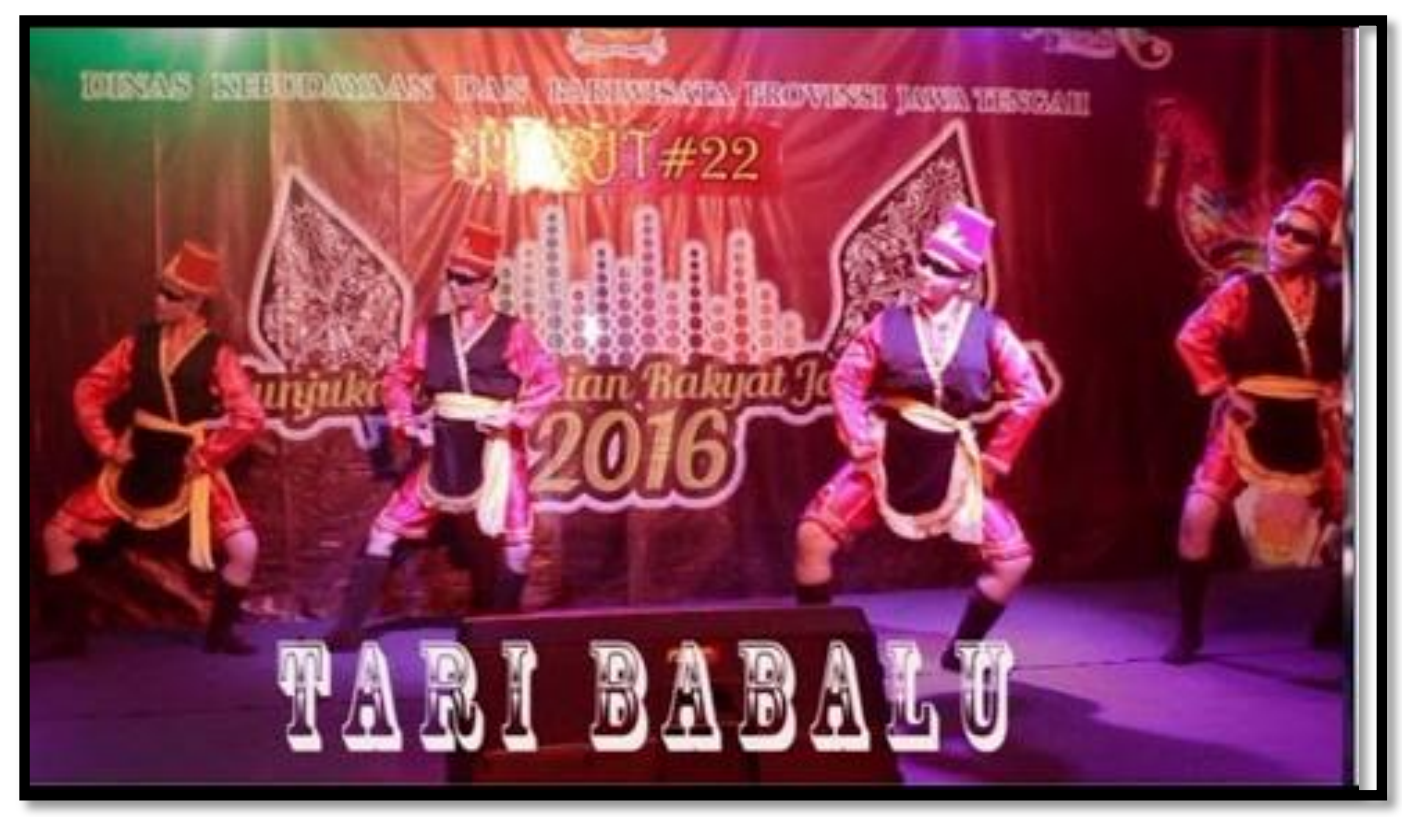

Foto 4.62 Pementasan Kesenian Babalu oleh Sanggar Puspo Budoyo Sumber : Adilah Endarini, 8 Juli 2016

Foto 4.62 merupakan pementasan Kesenian Babalu di acara PKRJT (Pekan Kesenian Rakyat Jawa Tengah ) di Kota Semarang yang dibawakan oleh Sanggar Puspo Budoyo Semarang. Hal ini menunjukan bahwa Kesenian Babalu mulai dikenal tidak hanya pada masyarakat Kabupaten Batang saja namun telah dikenal oleh beberapa masyarakat di luar Kabupaten Batang contohnya di Kota Semarang.

Pemanfaatan Kesenian Babalu juga dilakukan melalui sebuah lukisan Karakter Penari Kesenian Babalu di dinding ( MURAL) oleh Kedjil Bergerak yang bekerjasam dengan Pemerintah Kabupaten Batang. Lukisan menjadi daya tarik masyarakat untuk berfoto atau hanya sekedar menonton. Berikut foto 4.63 merupakan mural yang berada di perempatan lampu lalu lintas Jalan Ahmad Yani menuju kearah Jalan R.A Kartini 


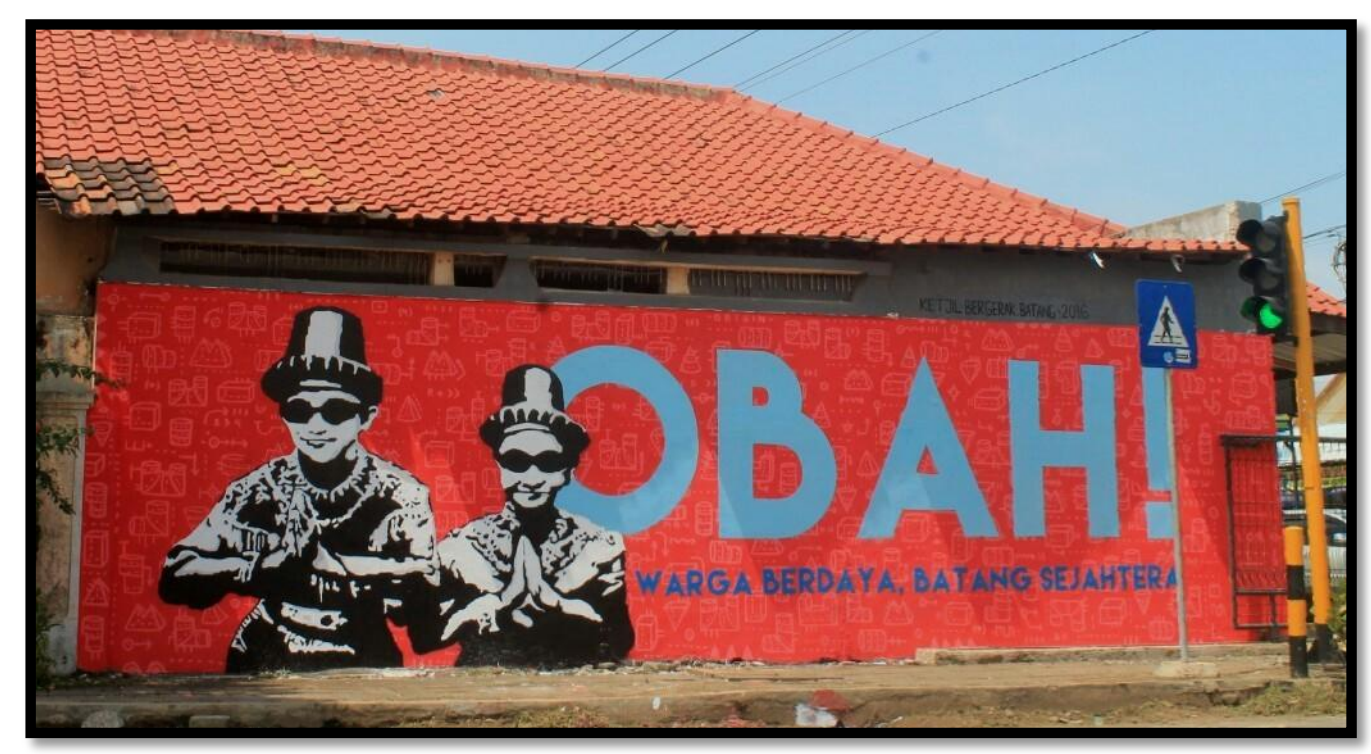

Foto 4.63 Mural Karakter Penari Kesenian Babalu Sumber : Adilah Endarini, 6 Juli 2016

Foto 4.63 merupakan lukisan penari Kesenian Babalu yang dikerjakan oleh Komunitas Kedjil Bergerak di bulan Maret 2016 yang saat itu berkunjung ke Kabupaten Batang. Kedjil Bergerak tertarik dengan Karakter Kesenian Babalu karena Kesenian Babalu merupakan Kesenian leluhur yang keberadaannya harus dilestarikan.

\subsubsection{Pengembangan}

Pengembangan Kesenian Babalu merupakan usaha memperbaiki beberapa aspek-aspek yang terdapat didalam Kesenian Babalu. Perbaikan dalam maksud suatu pengembangan yang tetap tidak melepas jati diri kesenian yang sebenarnya. Hal ini merupakan perkembangan Kesenian Babalu di Sanggar Putra Budaya Desa Proyonanggan Kabupaten Batang yang terdiri dari perkembangan gerak dalam Kesenian Babalu, perkembangan Iringan dalam Kesenian Babalu dan perkembangan 
Kostum dalam Kesenian Babalu di Sanggar Putra Budaya Desa Proyonanggan Kabupaten Batang.

Perkembangan Kesenian Babalu yang dilakukan oleh Sanggar Putra Budaya dilakukan agar Kesenian Babalu dapat terus dinikmati oleh masyarakat Kabupaten Batang. Namun perkembangan-perkembangan yang dilakukan oleh Sanggar Putra Budaya tanpa merubah dan tetap memegang erat kekhasan Kesenian Babalu di Sanggar Putra Budaya. Adapun perkembangan yang pertama yaitu sebagai berikut :

\subsubsection{Perkembangan Gerak}

Perkembangan gerak yang terdapat dalam Kesenian Babalu di Sanggar Putra Budaya Desa Proyonanggan Kabupaten Batang terdapat pada penambahan gerak dan variasi di ragam gerak silat dan ragam gerak jalan ditempat serta ditarikan dengan gerakan bertempo lebih cepat. Namun penambahan dan pengurangan gerak dalam kesenian Babalu dilakukan dikarenakan menyesuaikan permintaan dari penanggap kesenian. Jika sebenarnya Kesenian Babalu dalam pertunjukannya biasa berdurasi 10-15 menit namun dikarenakan permintaan dari penanggap durasi pertunjukan Kesenian Babalupun dikurangi menjadi 5menit. Jadi gerakan yang ditarikanpun akan dikurangi beberapa ragam geraknya. Berikut merupakan hasil wawancara peneliti bersama dengan Bapak Suprayetno selaku penanggungjawab Kesenian Babalu di Sanggar Putra Budaya Desa Proyonanggan Kabupaten Batang pada tanggal 3 April 2017 adalah sebagai berikut :

“...perkembangan gerak tari dalam kesenian Babalu sebenarnya tinggal menyesuaikan siapa yang nanggap mbak, dahulu kesenian babalu di pertunjukan sampai berjam-jam namun sekarang sudah dipersingkat menjadi 7-10menit, pernah ketika kesenian Babalu disuruh tampil di indosiar di acara Bintang Pantura hanya dikasih waktu cuma 
3 menit saja mbak, jadi perkembangan gerak tari yaa menyesuaikan permintaan dan durasi permintaan dari penanggapnya mbak".

Perkembangan gerak dalam kesenian Babalu di Sanggar Putra Budaya Desa Proyonanggan Kabupaten Batang dapat di kreasikan lagi sesuai permintaan dari penanggap kesenian namun dalam proses perkembangan tetap berpegangan pada ciri khas kesenian Babalu yang sudah ada.

\subsubsection{Perkembangan Iringan}

Perkembangan iringan dalam kesenian Babalu yang terdapat di Sanggar Putra Budaya Desa Proyonanggan Kabupaten Batang yaitu terdapat pada penambahan alat musik berupa kendhang jaipong, balungan, keyboard, tamborin dan perkusi dan penambahan senggakan suara dari pemain musik kesenian Babalu, dahulu kesenian Babalu iringannya sangat sederhana yang hanya menggunakan kenthongan, rebana dan kendhang saja namun seiring berkembangnya waktu pada tahun 2013 dalam pertunjukan Kesenian Babalu terkesan lebih ramai dan lebih enerjik dengan gerakan yang lumayan cepat.

Penambahan alat musik berupa kendang jaipong membuat pertunjukan Kesenian Babalu lebih menarik. Selain itu kesenian Babalu juga menambah personil vokal agar semakin bersemangat dan kompak dalam meramaikan pertunjukan. Durasi yang diperlukan dalam mempertunjukan Kesenian Babalu mengalami perkembangan menjadi lebih pendek namun tetap menarik dan lumayan dinikmati Mayarakat di Kabupaten Batang. 


\subsubsection{Perkembangan Kostum}

Sanggar Putra Budaya Desa Proyonanggan Kabupaten Batang melestarikan Kesenian Babalu di Kabupaten Batang melalui upaya pengembangan kesenian salah satunya yaitu perkembangan kostum yang terdapat dalam Kesenian Babalu. Adapun perkembangan kostum dalam kesenian Babalu tidak terlalu banyak, hanya terdapat pada penambahan sampur serta penambahan aksesoris-aksesoris tambahan tanpa menghilangkan ciri khas yang terdapat di dalam kostum Kesenian Babalu pada jaman dahulu.

Perkembangan gerak, iringan dan kostum dalam Kesenian Babalu di Sanggar Putra Budaya Desa Proyonanggan Kabupaten Batang dilakukan agar keberadaan Kesenian Babalu di Kabupaten Batang tetap terjaga dan tetap dinikmati oleh masyarakat di Kabupaten Batang dan sekitarnya. Sanggar Putra Budaya di Desa Proyonanggan Kabupaten Batang berperan aktif dalam perkembangan Kesenian Babalu, hal ini dilakukan agar kesenian Babalu tetap dapat menarik masyarakat dan dapat menyesuaikan perkembangan zaman dengan berpatokan pada nilai-nilai tradisi yang sudah ada. Kesenian Babalu dari awal mula terbentuk hingga tahun 2017 mengalami perkembangan-perkembangan dalam bentuk pertunjukannya. Berikut merupakan penjelasan singkat proses perkembangan kesenian Babalu yang berasal di Kabupaten Batang.

\subsubsection{Perkembangan Kesenian Babalu}

Perkembangan Kesenian Babalu menuju ke tahun 1970 mulai mengalami penurunan dalam pertunjukannya hal ini dikarenakan oleh beberapa faktor yang mempengaruhi seperti banyaknya para pemain kesenian Babalu yang telah 
meninggal dunia serta munculnya kesenian-kesenian kreasi baru yag digemari masyarakat pada tahun 1970. Hal tersebut menyebabkan keberadaan kesenian Babalu mulai jarang ditemui sehingga lambat laun minat masyarakat mulai menurun dalam menikmati kesenian Babalu. Pada akhirnya sekitar tahun 1986 Kesenian Babalu mengalami kevakuman baik dari pemainnya maupun penikmat seninya.

Kevakuman Kesenian Babalu berlangsung cukup lama hingga pada tahun 2000 salah satu tokoh seniman Batang yaitu Bapak Suprayetno mencoba membangkitkan kembali kesenian Babalu dan mengemas kesenian Babalu menjadi kesenian yang bisa dinikmati di semua kalangan masyarakat. Bapak Suprayetno dibantu oleh para pecinta seni di Kabupaten Batang akhirnya menciptakan perkembangan Kesenian Babalu dengan sebuah tarian yang di namakan Tari Babalu. esenian Babalu yang dikembangkan Bapak Suprayetno dan para pelaku seni di Kabupaten Batang mendapat respon yang sangat baik oleh masyarakat, Hingga akhirnya dari tahun 2000 menuju ke tahun 2010 Kesenian Babalu terus mengalami perbaikan perkembangan baik dari segi Iringan, Gerak dan Tata Busananya. Pertunjukan Kesenian Babalu pada tahun 2000-2010 kurang lebih berdurasi sekitar 10 menit, namun hal tersebut bisa berubah-ubah sesuai dengan permintaan dari penanggap kesenian. Perkembangan Kesenian Babalu terus berjalan dengan mengadakan kegiatan pelatihan tari yang terbuka dan rutin melalui Sanggar Putra Budaya kepada masyarakat Kabupaten Batang. Berikut foto 4.64 merupakan perkembangan pertunjukan kesenian Babalu pada tahun 2017 yang sudah menggabungkan musik dengan tari dan kostum yang telah diperbaiki. 


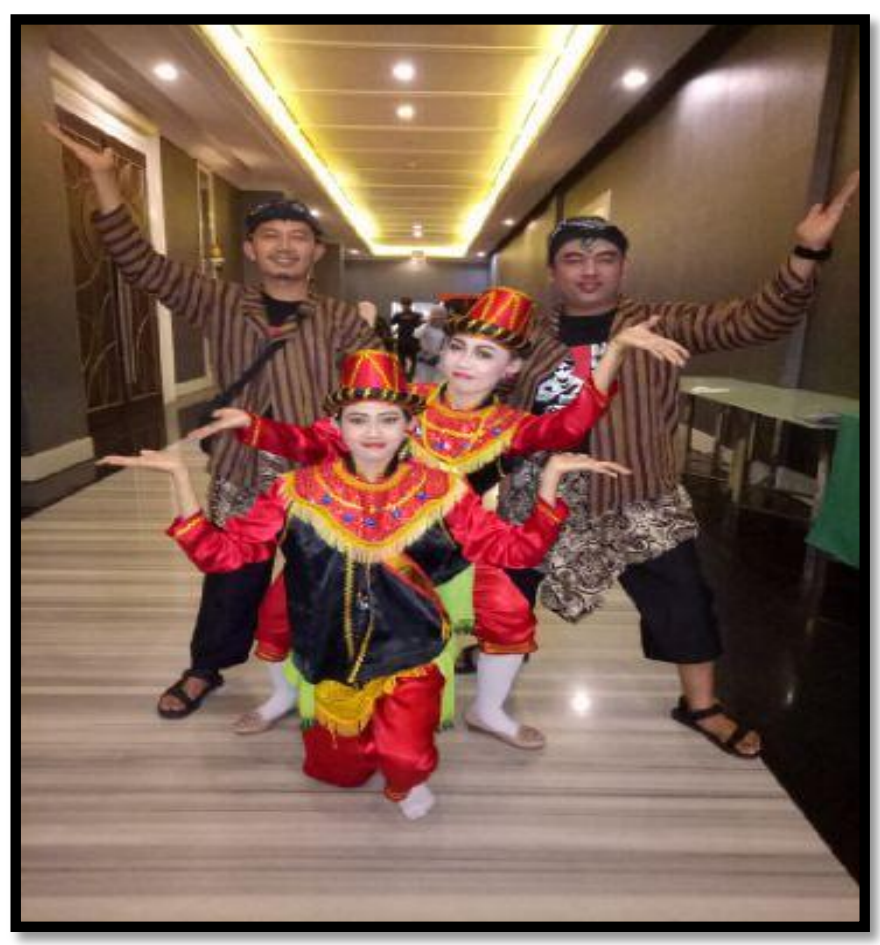

Foto 4.64 Perkembangan Kesenian Babalu tahun 2017 Sumber : Dok.Pribadi Sanggar Putra Budaya, 6 Juli 2017

Foto 4.64 merupakan perkembangan Kesenian Babalu pada tahun 2017 yaitu dari segi kostum yang di kreasikan dengan menambah sampur hijau yang diikatkan di pinggang serta penambahan aksesoris yang terdapat pada bagian leher. Kostum yang dikenakan oleh para pemusik kesenian Babalu pada jaman dahulu hanya menggunakan pakaian ala kadarnya, namun semenjak tahun 2000-2017 kostum para pemusik kesenian Babalu menggunakan jarik, celana dan baju kain lurik agar terkesan lebih rapi dan kompak. Perkembangan Kesenian Babalu di tahun 2010-2017 memang banyak baik dari segi iringan, tari, dan tata busananya namun hal tersebut tidak lepas dari nilai-nilai yang ada dan tetap mempertahankan keaslian kesenian Babalu yang ada pada jaman dahulu. 
Sanggar Putra Budaya sebagai tempat pelestarian Kesenian Babalu kian waktu semakin maju dan berkembang di Kabupaten Batang. Pada tahun 2017 tepatnya tanggal 28 Agustus 2017 salah satu pelatih Sanggar Putra Budaya yaitu Suningsih S.Pd., M.Pd memperoleh penghargaan dari Dinas Pendidikan dan Kebudayaan Kabupaten Batang sebagai kategori Pegiat Seni Tari Terbaik seKabupaten Batang dalam acara Pameran Pendidikan yang diadakan di Jalan Veteran Alun-alun Kabupaten Batang.

Penganugerahan yang diberikan kepada Suningsih S.Pd., M.Pd tidak lepas dari prestasi-prestasi yang telah diperoleh Suningsih dalam membawa nama Kabupaten Batang dalam bidang tari sampai dengan tahun 2017. Suningsih merupakan seorang guru Seni Budaya di Smp N 9 Batang dan juga menjadi Pelatih Kesenian Babalu di Sanggar Putra Budaya Desa Proyonanggan Kabupaten Batang. Suningsih selaku pelatih tari berbakat pernah menjuarai FLS2N dan berbagai kegiatan lomba-lomba tari lainnya di Kabupaten Batang. Hal ini membuktikan bahwa Sanggar Putra Budaya mempunyai seorang pelatih yang berbakat sesuai dengan bidangnya dalam mencetak siswa-siswinya menjadi pribadi yang baik dalam berekspresi diri.

Sanggar Putra Budaya Desa Proyonanggan Kabupaten Batang dalam usaha pelestariannya dilakukan dengan mengadakan kegiatan pelatihan Kesenian Babalu secara rutin dan Kesenian lainnya sebagai wujud Upaya Pelestarian Kesenian Tradisional. Berikut Foto 4.65 merupakan piala Penghargaan yang diberikan Pemerintah Kabupaten Batang kepada Suningsih. 


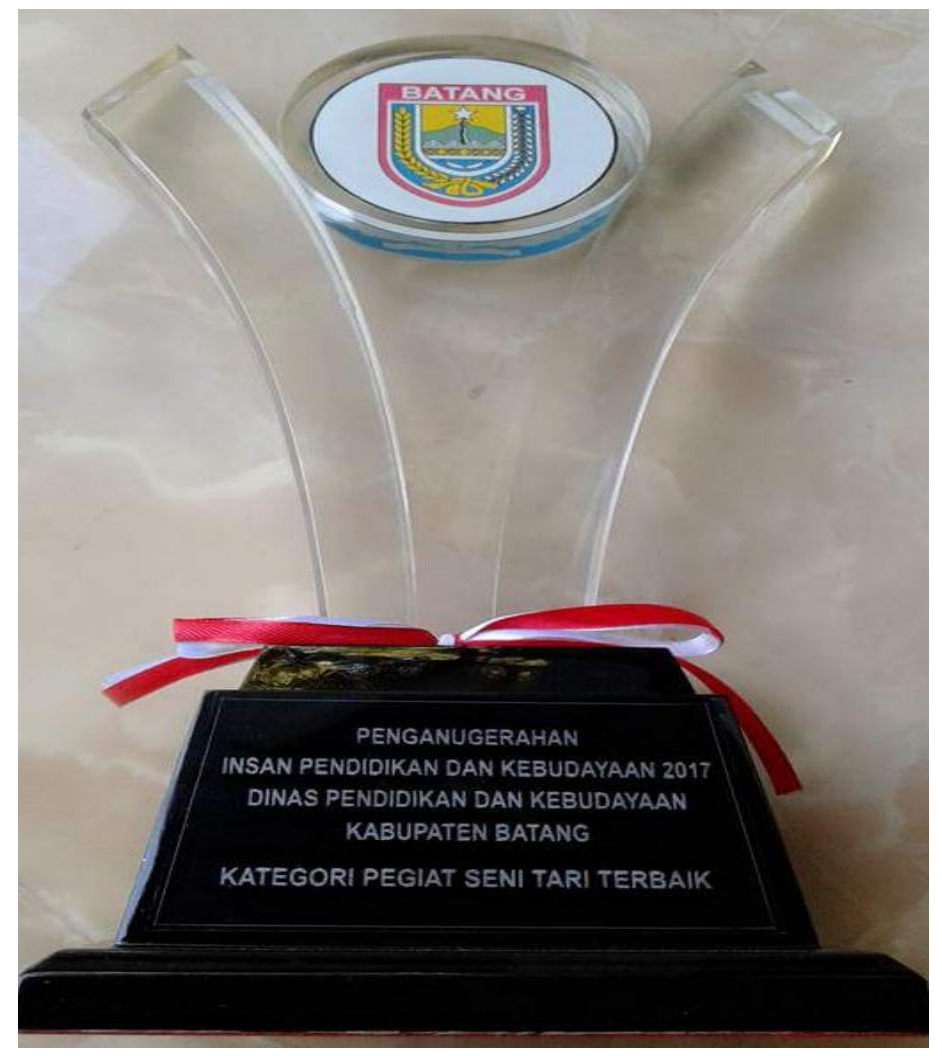

Foto 4.65 Piala penghargaan Pegiat Seni Tari Terbaik tahun 2017 Sumber : Dok.Pribadi Sanggar Putra Budaya, 11 September 2017

Foto 4.6 merupakan piala penghargaan pegiat seni tari terbaik tahun 2017 yang diserahkan oleh Bapak Bupati Kabupaten Batang yaitu Bapak Wihaji S.Ag, M.Pd., pada acara Pameran Pendidikan di Halaman Veteran Alun-alun Kabupaten Batang. Suningsih mempersembahkan penghargaan yang diperolehnya untuk keluarga, teman-teman serta untuk Sanggar Putra Budaya. Selain piala, Suningsih juga memperoleh sertifikat penghargaan. Berikut Foto 4.66 merupakan Sertifikat Penghargaan yang diperoleh Suningsih sebagai Pegiat Seni Tari Terbaik tahun 2017.

Foto 4.66 Sertifikat penghargaan Pegiat Seni Tari Terbaik tahun 2017 
Sumber : Dok.Pribadi Sanggar Putra Budaya, 11 September 2017 


\section{BAB 5}

\section{PENUTUP}

\subsection{Simpulan}

Kesenian Babalu merupakan kesenian yang berasal dari Kabupaten Batang dan dilestarikan di Sanggar Putra Budaya Desa Proyonanggan Kabupaten Batang. Kesenian Babalu muncul kembali ditengah masyarakat Kabupaten Batang berawal dari niat para seniman dan masyarakat di Kabupaten Batang yang ingin membangkitkan dan melestarikan kembali kesenian Babalu melalui Sanggar Putra Budaya Desa Proyonanggan Kabupaten Batang. Bentuk pertunjukan yang terdapat dalam Kesenian Babalu terdiri dari tiga tahapan yakni awal, inti, dan akhir. Persiapan awal dalam pertunjukan Kesenian Babalu ditandai dengan bunyi peluit oleh penari Kesenian Babalu lalu penari memasuki panggung dengan ragam gerak kaki jalan ditempat. Inti pertunjukan Kesenian Babalu ditandai dengan ragam gerak diantaranya yaitu ragam gerak langkah tepuk dan ragam gerak silat. Penutup dalam pertunjukan Kesenian Babalu ditandai dengan ragam gerak jalan ditempat lalu para penari berjalan keluar panggung. Selain itu Bentuk Kesenian Babalu juga dimunculkan melalui elemen dasar tari dan elemen pendukung tari. Elemen dasar tari terdiri dari gerak, ruang, dan waktu. Elemen pendukung tari terdiri dari musik, gerak tata busana, tata rias, tempat pentas, waktu pelaksanaan, tata suara, dan penonton.

Upaya pelestarian Kesenian Babalu dilakukan melalui tiga tahap yaitu perlindungan, pemanfaatan, dan pengembangan. Upaya perlindungan kesenian 
Babalu dilakukan melalui pelatihan tari di Sanggar Putra Budaya, Upaya pemanfaatan dilakukan melalui pementasan-pementasan Kesenian Babalu dan upaya perkembangan dilakukan melalui perkembangan gerak, iringan dan tata busana dalam kesenian Babalu di Sanggar Putra Budaya Desa Proyonanggan Kabupaten Batang.

\subsection{Saran}

Saran yang dapat diberikan oleh peneliti adalah :

a. Bagi pembina Kesenian Babalu di Sanggar Putra Budaya, agar selalu memperhatikan dunia luar dengan berbagai modernisasi yang terjadi didalamnya namun tetap menjaga ciri khas tradisi Kesenian Babalu yang sesungguhnya.

b. Bagi masyarakat yang ikut serta dalam kegiatan pelestarian Kesenian Babalu di Sanggar Putra Budaya Desa Proyonanggan Kabupaten Batang untuk selalu menjaga kekompakan dan kerjasama dalam menumbuhkan rasa cinta akan kesenian yang ada dengan cara saling toleransi terhadap sesama untuk mempertahankan kesenian tersebut agar tetap lestari dan dapat dinikmati oleh para penerus generasi bangsa yang akan datang. 


\section{DAFTAR PUSTAKA}

AMBARWANGI, Sri; SUHARTO, Suharto. REOG AS MEANS OF STUDENTS' APPRECIATION AND CREATION IN ARTS AND CULTURE BASED ON THE LOCAL WISDOM. Harmonia: Journal of Arts Research and Education, [S.1.], v. 14, n. 1, p. 37-45, Mar. 2014. ISSN 2541-2426. Available at: <https://journal.unnes.ac.id/nju/index.php/harmonia/article/view/2789>. Date accessed: $17 \quad$ Jan. 2018. doi:http://dx.doi.org/10.15294/harmonia.v14i1.2789.

Bastomi, Suwaji.1988. Apresiasi Kesenian Tradisional. Semarang: IKIP Press.

Bogdan dan Taylor dalam Sugiyono. 2008. Penelitian Pendidikan Pendekatan Kuantitatif, Kualitatif, $R \& D$. Bandung: ALFABETA

Budhi Palupi, Febriana. 2011. Bentuk Pertunjukan Dan Makna Simbolis Kesenian Babalu Di Kabupaten Batang. Skripsi. Jurusan Seni Drama, Tari dan Musik: UNNES

Gupita, Widuandi. 2012. Bentuk Pertunjukan Kesenian Jamilin di Desa Jatimulya Kecamatan Suradadi Kabupaten Tegal. Jurnal Seni Tari Volume 1 Nomer 1 Tahun 2012. Semarang: Sendratasik UNNES

Handayani, Sri. 2015. Upaya Pelestarian Eksistensi Kesenian Barongan Setyo Budoyo di Desa Loram Wetan Kecamatan Jati Kabupaten Kudus. Skripsi. Jurusan Seni Drama, Tari dan Musik: UNNES

Handayaningrum, W. (2016). Science-Based Thematic Cultural Art Learning in Primary School (2013 Curriculum). Harmonia: Journal Of Arts Research And Education, 16(1), 14-23. doi:http://dx.doi.org/10.15294/harmonia.v16i1.6766

Idris, M., Mustaffa, N., \& Yusoff, S. (2016). Preservation of Intangible Cultural Heritage Using Advance Digital Technology: Issues and Challenges. Harmonia: Journal Of Arts Research And Education, 16(1), 1-13. doi:http://dx.doi.org/10.15294/harmonia.v16i1.6353

Jazuli, M. 1994.Telaah Teoretis Seni Tari. Semarang: IKIP Semarang Press

Kusmayati, Hermien. 2000. Arak-arakan Seni Pertunjukan. Yogyakarta: Tarawang Press 
Kusumastuti, Eny. 2009. "Ekspresi Estetis dan Makna Simbolis Kesenian Laesan”. Jurnal Harmonia. 9(1) : 1-9. Diunduh di http://download.portalgaruda.org/article.php?article $=135699 \&$ val $=5651$ tanggal 5 Februari 2017.

Kusumastuti, Eny, dan Hartono. 2017. "Kuda Debog Dance for Children's Social Development". Jurnal Ponte Multidiciplinary Jurnal of Science and Research. 73(6) : 355-371. Diunduh di www.pontejurnal.net tanggal 31 Juli 2017.

Khutniah, Nainul. 2013. "Upaya mempertahankan Eksistensi Tari Krida Jati di Sanggar Hayu Budaya Kelurahan Pengkol Kecamatan Jepara Kabupaten Jepara". Skripsi. Jurusan Seni Drama, Tari dan Musik: UNNES

Miles, Matthew, dan Michael Huberman. 2009. Analisis Data Kualitatif Buku Sumber Tentang Metode-Metode Baru. Terjemahan Tjetjep Rohendi Rohidi. Jakarta: UI Press.

Murgiyanto, Sal. 1983. Koreografi Pengetahuan Dasar Komposisi Tari. Jakarta: Ditjendasmen Depdikbud.

Rohendi, Tjetjecep Rohidi. 2011. Metodologi Penelitian Seni. Semarang: Cipta Prima Nusantara

Sedyawati, Edi. 2007. Budaya Indonesia: Kajian Arkeologi Seni, dan Sejarah. Jakarta:PT Raja Grafindo Persada.

Sedyawati, Edi. 2008. KeIndonesiaan Dalam Budaya. Jakarta: Wedatama Widya Sasatra

Suharto, S., \& Aesijah, S. (2014). THE LESUNG MUSIC IN THE VILLAGE OF LEDOK BLORA REGENCY. Harmonia: Journal Of Arts Research And Education, $14(1)$, 65-71. doi:http://dx.doi.org/10.15294/harmonia.v14i1.2851

Soedarsono. 2001. Metodologi Penelitian Seni Pertunjukan dan Seni Rupa. Bandung: MSPI (Masyarakat Seni Pertunjukan Indonesia).

Sri Rahayu, Diah. 2013. Kajian Bentuk dan Fungsi Pertunjukan Kesenian Lengger Budi Lestari Kecamatan Kledung Kabupaten Temanggung. Skripsi. Jurusan Seni Drama, Tari dan Musik: UNNES 
Sugiyono. 2010. Metode Penelitian Pendidikan Pendekatan Kuantitatif, Kualitatif, $R \& B$. Bandung: ALFABETA

Sutomo. 2011. Manajemen Sekolah. Semarang : Universitas Negeri Semarang Press

Syaifudin, Ahmad, dkk. 2014. Pedoman Penulisan Skripsi. Semarang: Fakultas Bahasa dan Seni Universitas Negeri Semarang.

Yulistio, Anggun. 2011. Manajemen Pengamen Calung Sanggar Seni Jaka Tarub di Kabupaten Tegal. Skripsi. Jurusan Pendidikan Sendratasik. Semarang: FBS UNNES.

\section{GLOSARIUM}

$\begin{array}{ll}\text { Asto } & \text { : Tangan } \\ \text { Ayo } & : \text { Kata ajakan } \\ \text { Bapangan } & : \text { Gerakan kedua tangan membuka lebar dan ditekuk } 90 \\ & \text { derajat ke arah atas } \\ \text { Blushon } & : \text { Pemerah pipi } \\ \text { Buka } & : \text { Pembuka } \\ \text { Cilpa } & : \text { Seni (kata sifat) }\end{array}$




\begin{tabular}{|c|c|}
\hline Copy & : Salin \\
\hline Cultural & : Kebudayaan \\
\hline Di uri-uri & : Dilestarikan \\
\hline Duwe Gawe & : Punya hajatan \\
\hline Ekstern & : Luar \\
\hline Eye Shadow & : Pewarna kelopak mata \\
\hline Gejug & : Menghentakkan ujung jari kaki dengan tumit diangkat \\
\hline Gendhing & : Istilah suara pada instrumen musik Jawa \\
\hline Gesture & : Sikap tubuh yang bermakna \\
\hline Gong & : Alat musik tradisional Jawa yang terbuat dari leburan \\
\hline & logam dengan permukaan bundar \\
\hline Indoor & : Dalam ruangan \\
\hline Intern & : Dalam \\
\hline Interview & : Wawancara \\
\hline Jarik & : Kain untuk menutupi bagian pinggul sampai kaki \\
\hline Jidor & : Alat musik yang terbuat dari batang bambu \\
\hline Kadek & : Sejak \\
\hline Kanggo & : Untuk \\
\hline
\end{tabular}


Kendhang

Kenong

Kenthongan

Keyboard

Kliwon

Kupluk

Lambeyan

Leyek

Lighting

Lipstik

Live

Make Up

Mayuk

Malangkerik

Mendhak

Menthang
: Intrumen pada alat musik tradisional Jawa yang pemakaiannya di pukul

: Instrumen dalam gamelan yang berbentuk menyurupai gong namun berukuran lebih kecil

: Intrumen musik yang terbuat dari kayu

: Alat musik yang dimainkan seperti piano

: Nama hari dalam sepasaran Jawa dan Bali

: Atasan kepala atau topi

: Gerakan tangan melambai-lambai ke arah depan dan belakang

: Posisi badan doyong kearah kanan atau kiri

: Pencahayaan

: Pewarna bibir

: Langsung

: Alat rias

: badan condong ke depan

: Sikap tangan dan kedua tangan di pinggang, posisi tangan kiri di pinggang sebelah kiri lalu tangan kanan di pinggang sebelah kanan

: Posisi badan diturunkan kebawah

: Kedua Tangan/Kaki di buka lebar kearah samping 
Mbah

Mboten

Napak

Ndegek

Ngepel

Nggih

Ngrayung/Ngruji

Nyekithing

Ogek Bahu

Ono

Outdoor

Pacak gulu

Pantura

Parikan
: Sebutan bahasa Jawa untuk nenek

: Tidak

: Posisi kedua kaki menyentuh lantai secara penuh

: Posisi dada di busungkan dan badan berdiri tegap

: Tangan menggengam

: Iya

: Sikap jari merapat dengan ibu jari menempel pada telapak tangan, pergelangan tangan membentuk sudut $90^{0}$

: Sikap ujung ibu jari bertemu dengan ujung jari tengah yang membentuk lingkaran, jari yang lainnya menekuk mengikuti jari tengah hanya saja tidak menempel ibu jari

: Gerakan bahu dan pinggul di putar kesamping kanan dan kiri

: Ada

: Di luar ruangan

: Gerakan kepala yang digelengkan bersamaan dengan dagu

: Pantai Utara Jawa Tengah

: Pantun atau kata-kata yang berisi cerita humor 
Penanggap

Pendopo

Pie

Rapek

Rebana

Stagen

Sembah

Siasat

Speaker

Su-cilpa

Tepuk

Toklek

Tolehan

Trap cethik
: Orang yang mengadakan hajatan

: Tempat atau halaman yang dipakai untuk kegiatan

: Bagaimana

: Hiasan pada kostum kesenian Babalu

: Sejenis instrumen yang tebuat dari kulit kambing yang berbentuk bundar dan pipih

: Kain tenun yang berfugsi untuk melilitkan dan

mengencangkan kain putih yang telah dipakai

sebelumnya agar tidak lepas dengan menggunakan

bantuan peniti sebagai pengait

: Sikap kedua tangan disatukan dengan gerakan kepala menunduk

: Cara

: Pengeras suara

: Dilengkapi bentuk yang indah, dihiasi dengan indah

: Menepukkan kedua tangan

: Posisi Kepala dipatahkan kearah kanan dan kiri

: Gerakan kepala dengan memutar

: Tangan posisi tepat di samping pinggul 
Trap Puser

Ukel

Wis
: Posisi tangan kanan dan tangan kiri tepat di depan pusar

: Kaki berjalan kecil-kecil secara cepat

: Gerakan pergelangan tangan diputar kearah dalam

: Sudah 


\section{LAMPIRAN-LAMPIRAN}

Lampiran 1

\section{INSTRUMEN PENELITIAN}

1. Pedoman Observasi

Observasi penelitian ini dilaksanakan di Desa Proyonanggan Kabupaten Batang. Adapun hal-hal yang diobservasi dalam penelitian sebagai berikut :

1.1 Lokasi dan Keadaan Desa Proyonanggan Kabupaten Batang

1.2 Kondisi geografis meliputi letak Kesenian Babalu di Sanggar Putra Budaya

1.3 Keadaan Demografis meliputi : 
a. Kondisi penduduk berdasarkan jenis kelamin,

b. Kondisi penduduk berdasarkan pendidikan,

c. Kondisi penduduk berdasarkan mata pencaharian,

d. Kondisi penduduk berdasarkan agama.

2. Pedoman Wawancara

Responden terdiri atas: (1) Penanggungjawab Sanggar, (2) Pelatih, (3) Penari

\subsection{Penanggungjawab Sanggar sekaligus pemusik Kesenian Babalu di Sanggar}

Putra Budaya Desa Proyonanggan Kabupaten Batang ( Bapak Suprayitno )

Daftar Pertanyaan:

1. Apa yang melatarbelakangi adanya Sanggar Putra Budaya?

2. Sejak kapan Berdirinya Kesenian Babalu di Kabupaten Batang?

3. Bagaimana sejarah terbentuknya Kesenian Babalu di Sanggar Putra Budaya Desa Proyonanggan Kabupaten Batang?

4. Kapan pertunjukan Kesenian Babalu dilaksanakan?

5. Kapan pelaksanaan kegiatan pelatihan Kesenian Babalu di Sanggar Putra Budaya?

6. Siapa sajakah personil Kesenian Babalu?

7. Apa saja alat musik yang dipakai dalam kesenian Babalu ?

8. Bagaimana kondisi awal pementasan sampai akhir pementasan dalam pertunjukan kesenian Babalu?

9. Berapa jumlah anggota baik dari pelatih, penari dan pemusik dalam kesenian Babalu? 
10. Bagaimana minat para penari dan pemusik kesenian Babalu?

11. Bagaimana Kualitas sarana dan Prasarana kesenian Babalu di Sanggar Putra Budaya?

12. Apakah kondisi lingkungan Desa sudah mendukung pelaksanaan pelatihan kesenian Babalu di Sanggar Putra Budaya?

13. Apakah pertunjukan kesenian Babalu terdapat pembagian dalam proses pelatihannya, jika iya apa tujuannya?

14. Dimana sajakah kesenian Babalu sudah dipertunjukkan?

15. Hal yang menarik apakah yang ada di dalam kesenian Babalu?

16. Apa saja Koleksi Kostum di Sanggar Putra Budaya?

17. Apa Kendala dalam kegiatan pelestarian Kesenian Babalu di Sanggar Purtra Budaya?

\subsection{Wawancara dengan Ibu Suningsih selaku Pelatih dan Penari Kesenian} Babalu di Sanggar Putra Budaya Kabupaten Batang

Daftar Pertanyaan :

1. Sejak kapan anda menjadi pelatih tari Babalu?

2. Apakah latar belakang pendidikan anda seni tari atau seni musik atau bahkan bukan jurusan seni?

3. Bagaimana awalnya anda mendapatkan ide dalam menambahkan variasi gerak dalam kesenian Babalu?

4. Motivasi apa yang mendorong anda untuk menjadi pelatih dalam pelestarian kesenian Babalu? 
5. Dimana saja Kesenian Babalu dilatihkan?

6. Berapa kali anda melatih kesenian Babalu dalam satu bulan?

7. Apakah ada ketentuan bagi masyarakat di Desa dalam mengikuti kegiatan kesenian Babalu?

8. Apakah prasarana dan sarana dalam pelatihan Kesenian Babalu di Sanggar Putra Budaya sudah memadai, jika belum apa saja yang dibutuhkan?

9. Apakah penari dan pemukul sebelum ada kegiatan Pelatihan Kesenian Babalu di Sanggar Putra Budaya sudah bisa menari dan bemain alat musik?

10. Kendala apa yang dihadapi dalam pelestarian Kesenian Babalu di Kabupaten Batang?

11. Apakah kesenian Babalu mengalami perkembangan dari segi gerakannya?

12. Apakah kesenian Babalu mengalami perkembangan dari segi kostumnya?

13. Apakah kesenian Babalu mengalami perkembangan dari segi iringannya bahkan bentuk pertunjukannya?

14. Dimana sajakah kesenian Babalu pernah dipentaskan?

15. Dimana sajakah Pelatihan Kesenian Babalu dilaksanakan?

16. Apa saja koleksi kostum di Sanggar Putra Budaya Kabupaten Batang?

17. Selama kegiatan Pelatihan Kesenian Babalu berlangsung apa saja kendalanya?

18. Dalam setiap gerakan tari dalam Kesenian Babalu apakah ada makna tersendiri disetiap geraknya?

19. Untuk lagu yang dimainkan apakah ada kreteria dalam pemilihan lagu untuk mengiringi tarian? 
20. Bagaimana kostum yang dikenakan oleh pemain ketika pementasan?

21. Berapa dana yang harus dikeluarkan untuk bergabung di Sanggar Putra Budaya?

2.3 Penari Kesenian Babalu di Sanggar Putra Budaya Desa Proyonanggan Kabupaten Batang ( Rissa )

1. Sejak kapan anda menjadi penari Kesenian Babalu

2. Sebelum ada pelatihan tari di Sanggar Putra Budaya apakah anda sudah bisa menari

3. Apakah anda menguasai gerakan dalam setiap lagu yang di bunyikan oleh pemusik?

4. Apakah gerakan yang dilakukan sulit?

5. Apakah tujuan dan motivasi anda dalam ikut serta menjadi penari di Sanggar Putra Budaya?

6. Bagaimana proses pelatihan Kesenian Babalu di Sanggar Putra Budaya Desa Proyonanggan Kabupaten Batang?

7. Berapakali dalam satu bulan anda berlatih Kesenian Babalu di Sanggar Putra Budaya Desa Proyonanggan Kabupaten Batang?

8. Materi apa saja yang sudah anda kuasai?

\section{A. PEDOMAN STUDI DOKUMEN}

Obyek dokumentasi yang ditemukan antara lain:

1. Data Sejarah Kesenian Babalu dan Sanggar Putra Budaya. 
2. Data demografi letak Kesenian Babalu.

3. Video Pertunjukan Kesenian Babalu.

4. Foto pemain dalam pelatihan Kesenian Babalu.

5. Foto pemain dalam pertunjukan Kesenian Babalu

6. Foto saat wawancara.

7. Foto iringan Kesenian Babalu.

8. Foto dengan Narasumber.

Lampiran 2

Lampiran 3. Hasil Wawancara

Pedoman Wawancara

Bapak Suprayetno sebagai Pengelola dan Penanggungjawab Sanggar Putra Budaya Desa Proyonanggan Kabupaten ( 4 April 2017 )

1. Apa yang melatarbelakangi adanya Sanggar Putra Budaya?

- Latarbelakang adanya Sanggar Putra Budaya di Kabupaten Batang agar masyarakat dapat mempelajari Kesenian Babalu dan kesenian-kesenian tradisional yang lain mbak, selain itu juga dengan adanya Sanggar Putra Budaya kan dapat dijadikan sebagai wahana ekspresi bagi masyarakat dalam berkesenian mbak. Saya ingin masyarakat dikabupaten Batang dapat mencintai kesenian daerahnya sendiri maka dari itu saya dan teman-teman seni di Kabupaten Batang ingin melestarikan kesenian Babalu melalui Sanggar Putra Budaya ini 
2. Sejak kapan Berdirinya Kesenian Babalu di Kabupaten Batang?

- Kesenian Babalu berdiri sejak jaman penjajahan mbak, ya sekitar tahun 1940an. Namun jaman dahulu kesenian Babalu tidak berbentuk taru mbak tapi berbentuk ketoprak jawa cuma sekarang saya dan teman teman mengembangkan kesenian Babalu dengan gerakan tari di Sanggar Putra budaya.

3. Bagaimana sejarah terbentuknya Kesenian Babalu di Sanggar Putra Budaya Desa Proyonanggan Kabupaten Batang?

- Sejarahnya kesenian Babalu berawal dari kesenian Babalu dulunya dijadikan sebagai alat atau cara untuk membentuk siasat perang mbak lalu para pejuang di kabupaten Batang berkumpul untuk bermusyawarah dalam mencari siasat agar dapat mengelabuhi penjajah, nah caranya melalui kesenian babalu mbak. Sejak saat itu kesenian Babalu jadi sering ditampilkan mbak. Namun, lambat laun kesenian babalu mulai jarang di temui hingga akhirnya saya dan teman teman seniman Batang membentuk sanggar Putrabudaya untuk menghidupkan kembali kesenian Babalu, begitu mbak sejarahnya.

4. Kapan pertunjukan Kesenian Babalu dilaksanakan?

- Pertunjukan kesenian Babalu biasanya di tampilkan di acara-acara desa dan juga di acara-acara penyambutan tamu mbak. Selain itu pertunjukan Kesenian Babalu juga sering dipertunjukan diacara hajatan ataupun acara perayaan-perayaan di waktu tertentu, jadi untuk waktu pelaksanaan kesenian 
Babalu tidak menentu mbak tergantung permintaan dari penanggap kesenian Babalu

5. Kapan pelaksanaan kegiatan pelatihan Kesenian Babalu di Sanggar Putra Budaya?

- Pelaksanaan pelatihan di Sanggar Putra Budaya dilaksanakan pas hari minggu jam sembilan sampai jam sebelas siang mbak. Itu dilakukan secara rutin mbak.

6. Siapa sajakah personil Kesenian Babalu?

- Personil kesenian Babalu terdiri dari pemusik yang berjumlah 10 orang dan penarinya berjumlah 10 orang atau lebuh mbak. Penari dalam kesenian Babalu jika ditarikan dengan penari yang jumlahnya banyak akan terlihat lebih bagus mbak.

7. Apa saja alat musik yang dipakai dalam kesenian Babalu ?

- Alat musik yang dipakai ada kendang, rebana, demung, saron, kentongan, kempul dan gong. Tapi, juga kadang di tambah keyboard dan kendang jaipong untuk menambah ramai dalam pertunjukan kesenian Babalu mbak.

8. Bagaimana kondisi awal pementasan sampai akhir pementasan dalam pertunjukan kesenian Babalu?

- Pada awal pementasan para penari dan pengiring kesenian Babalu bersiapsiap di sebelah panggung ataupun di belakang panggung, kemudian para pemusik memasuki panggung dan mulai duduk memegang alat musik bagiannya masing-masing. Suatu bunyi peluit yang dikomando oleh salah satu penari merupakan bagian awal pementasan kesenian Babalu lalu disusul 
dengan bunyi rebana dan slogan Kabupaten Batang yaitu lagu Babalu Mbatang yang disertai dengan gerakan jalan ditempat. Kemudian pada bagian inti disusul dengan ragam gerak langkah tepuk, Sembah Berjalan, Ukel duduk, Silat, Doublestep, Tepuk Gejhug, Toleh Kanan Kiri, Sendi, dan Bapangan. Gerakan dalam kesenian Babalu di Sanggar Putra Budaya Kabupaten Batang sangat lincah dan penuh kekuatan karena menunjukan seorang prajurit wanita yang bersemangat dalam mengatur siasat perang melawan penjajah. Kemudian pada bagian akhir pertunjukan yaitu mulai dari ragam gerak Bapangan, Lambeyan, dan Dolanan Asto, kemudian ketika penari meninggalkan panggung dengan ragam gerak jalan ditempat akhirnya telah menunjukan bahwa berakhirnya suatu pertunjukan Kesenian Babalu

9. Berapa jumlah anggota baik dari pelatih, penari dan pemukul kesenian Babalu?

- Jumlah pelatih kesenian Babalu sekitar 10 orang mbak namun jadwal melatihnya berbeda-beda, jadi setiap ada pelatihan di sanggar putra budaya paling ada dua pelatih saja mbak, jadi digilir mbak. Lalu kalau untuk penari jumlahnya sekitar 10 orang namun jumlah penari dalam kesenian babalu bebas mbak boleh ditarikan tunggal kelompok ataupun berpasangan mbak, oh iya mbak jumlah penari kesenian babalu jika ditarikan oleh banyak penari malah terlihat semakin bagus mbak. Kemudian jumlah pemusik kesenian Babalu sekitar 10 orang mbak, asal semua alat sudah terisi mbak. Jadi kita 
menyesuaikan gimana acaranya, jika butuh personilnya sedikit ya kita menyesuaikan, jika butuh personil banyak ya kita adakan.

10. Bagaimana minat para penari dan pemusik kesenian Babalu?

- Minat para penari dan pemukul kesenian babalu sangat senang dan antusiasme dalam latihannya sangat tinggi mbak, mereka rela latihan sampai malam-malam lembur kalau ada tanggapan mendadak

11. Bagaimana Kualitas sarana dan Prasarana kesenian Babalu di sanggar putra budaya?

- Alhamdulillah sarana dan prasarana di sanggar putra budaya sudah memadai mbak, hal ini terlihat dari dukungan lurah desa proyonanggan yang mengijinkan pendopo kelurahan dijadikan tempat latihan tari sanggar putra budaya dan juga untuk sarana prasarana yang lain kita juga dibantu oleh pemerintah mbak. Seperti speaker namun speaker dari pemerintah sudah rusak jadinya kita beli speaker sendiri mbak, kalau untuk alat musiknya kita menggunakan gamelan yang berada di pedopo kabupaten batang mbak.

12. Apakah kondisi lingkungan Desa sudah mendukung pelaksanaan pelatihan kesenian Babalu di Sanggar Putra Budaya?

- sudah mbak

13. Apakah pertunjukan kesenian Babalu terdapat pembagian dalam proses pelatihannya, jika iya apa tujuannya?

- Ada mbak jadi untuk anak-anak yang telah mahir di pisahkan dan dimatangkan lagi sewaktu-waktu ada tanggapan mendadak, selain itu untuk 
anak-anak yang belum mahir akan terus kita beri pelatihan mbak dan secara lebih intensif mbak

14. Dimana sajakah kesenian Babalu sudah dipertunjukkan?

- Kesenian Babalu sudah dipertunjukan kemana-mana mbak, saya sampai lupa, ya tahun kemarin kesenian babalu di pertunjukan di inbox sctv, bintang pantura dan di hotel grand sahid mandarin pekalongan mbak. Kesenian babalu jua pernah di pertunjukan di bandung, jepara dan di semarang. Kalau di batang kesenian babalu sering dipertunjukan di alun-alun batang mbak di acara-acara tertentu, contohnya dulu juga pernah ditampilkan di acara batang expo mbak

15. Hal yang menarik apakah yang ada di dalam kesenian Babalu?

- Hal yang menarik dalam kesenian babalu terdapat pada gerakannya yang seperti seorang wanita keprajuritan lalu pada kostumnya seperti kostum prajurit dengan kupluk berkucirnya serta pada iringan musiknya yang menggunakan lagu babalu mbatang dan lagu ilir-ilir.

16. Apa saja koleksi kostum yang ada di Sanggar Putra Budaya Kabupaten Batang?

- Koleksi kostum yang ada di sanggar putra budaya ada Sanggar Putra Budaya Desa Proyonanggan Kabupaten Batang yaitu Kostum Tari Babalu, Kostum Tari Wira Pertiwi, Kostum Tari Sintren, dan Kostum Tari Kelinci mbak

17. Apa kendala dalam melestarikan kesenian Babalu? 
- Ya kendalanya tentu dalam membangkitkan minat masyarakat akan kecintaannya terhadap tari tradisi mbak

\subsection{Wawancara dengan Ibu Suningsih selaku Pelatih Kesenian Babalu di}

\section{Sanggar Putra Budaya Kabupaten Batang}

Daftar Pertanyaan :

1. Sejak kapan anda menjadi pelatih tari Babalu?

- Sejak saya berumur 17 tahun mbak, saya sudah sering mementaskan kesenian babalu sejak kecil hingga sekarang mbak

2. Apakah latar belakang pendidikan anda seni tari atau seni musik atau bahkan bukan jurusan seni?

- Saya dari pendidikan seni tari unnes mbak

3. Bagaimana awalnya anda mendapatkan ide dalam menambahkan variasi gerak dalam kesenian Babalu?

- Karena dengan perkembangan jaman dan semakin banyaknya muncul kesenian baru, saya merasa harus adanya perkembangan gerak dalam kesenian babalu agar terlihat lebih menarik lagi mbak, contohnya menambah variasi pada ragam gerak silat mbak, bisa di ulang-ulang ataupun di tambah gerakan-gerakan baru tanpa merubah gerakan aslinya mbak, jadi ya gerakan aslinya tetep dipakai dan ditambah dengan gerakan baru

4. Motivasi apa yang mendorong anda untuk menjadi pelatih dalam pelestarian kesenian Babalu?

- Karena saya ingin melestarikan kesenian tradisi yang sudah dirturunkan secara turun temurun dari kakek saya mbak, apalagi kesenian tersebut 
berasal dari daerah kita sendiri. Saya ingin masyarakat di kabupaten batang khususnya sudah mengenal bahkan mempelajari kesenian Babalu, dengan kegiatan pelatihan kesenian babalu di sanggar ini saya berharap keberadaan kesenian babalu tetap terjaga mbak.

5. Dimana sajakah kesenian Babalu melakukan latihan?

- Kesenian Babalu melakukan latihan di sanggar putra budaya tepatnya di pendopo kelurahan desa proyonanggan mbak, terus selain di pendopo kelurahan kadang kita juga latihan di pendopo kabupaten mbak, kadang juga di lapangan dan di jalan veteran. Asal anak-anak mau ya saya ngikut latihannya dimanapun mbak.

6. Berapa kali anda melatih kesenian Babalu dalam satu bulan?

- Sekitar 6 kali mbak, ada pelatihan yang dari sanggar Putra Budaya 4x dan saya juga melatih kepada siswa-siswi saya di sekolah mbak. Ya disekolah sekitar 2x dalam satu bulan. Tapi itu juga tidak pasti cuma 6x dalam 1 bulan mbak, kadang jika banyak permintaan anak-anak yang minta dilatih ya saya akan meluangkan waktu selagi saya bisa mbak.

7. Apakah ada ketentuan bagi masyarakat di Desa dalam mengikuti kegiatan kesenian Babalu?

- Tidak ada mbak, siapapun boleh belajar kesenian babalu, tidak dibatasi oleh usia maupun golongan mbak

8. Apakah prasarana dan sarana dalam pelatihan Kesenian Babalu di Sanggar Putra Budaya sudah memadai, jika belum apa saja yang dibutuhkan? 
- Alhamdulillah sarana prasarana yang ada sudah memadai mbak, Cuma mungkin akan lebih lengkap dengan pengadaan alat musik khusus dari pemerintah untuk sanggar putra budaya agar teman-teman seni dapat lebih gampang dalam berkesenian mbak.

9. Kendala apa yang dihadapi dalam pelestarian Kesenian Babalu di Kabupaten Batang?

- Kendalanya pada minat masyarakat mbak, saya ingin masyarakat mengenal bahkan mempelajari mbak namun kan saya juga tidak bisa memaksa keinginan masyarakat yang belum minat mbak

10. Apakah kesenian Babalu mengalami perkembangan dari segi gerakannya?

- Perkembangan gerak yang terdapat dalam Kesenian Babalu di Sanggar Putra Budaya Desa Proyonanggan Kabupaten Batang terdapat pada penambahan gerak dan variasi di ragam gerak silat dan ragam gerak jalan ditempat serta ditarikan dengan gerakan bertempo lebih cepat. Namun penambahan dan pengurangan gerak dalam kesenian Babalu dilakukan dikarenakan menyesuaikan permintaan dari penanggap kesenian. Jika sebenarnya kesenian Babalu dalam pertunjukannya biasa berdurasi 10-15 menit namun dikarenakan permintaan dari penanggap durasi pertunjukan Kesenian Babalupun dikurangi menjadi 5 menit. Jadi gerakan yang ditarikanpun akan dikurangi beberapa ragam geraknya mbak

11. Apakah kesenian Babalu mengalami perkembangan dari segi kostumnya?

- Sanggar Putra Budaya Desa Proyonanggan Kabupaten Batang melestarikan Kesenian Babalu di Kabupaten Batang melalui upaya 
pengembangan kesenian mbak, lha salah satunya yaitu perkembangan kostum yang terdapat dalam Kesenian Babalu, Adapun perkembangan kostum dalam kesenian Babalu tidak terlalu banyak mbak hanya terdapat pada penambahan pemakaian kacamata serta penambahan aksesorisaksesoris tambahan tanpa menghilangkan ciri khas yang terdapat di dalam kostum Kesenian Babalu pada jaman dahulu

12. Apakah kesenian Babalu mengalami perkembangan dari segi iringannya?

- Perkembangan iringan dalam kesenian Babalu yang terdapat di Sanggar Putra Budaya Desa Proyonanggan Kabupaten Batang yaitu terdapat pada penambahan alat musik berupa kendhang jaipong, balungan, keyboard, tamborin dan perkusi dan penambahan senggakan suara dari pemain musik kesenian Babalu mbak, dahulu kesenian Babalu iringannya sangat sederhana yang hanya menggunakan kenthongan, rebana dan kendhang saja namun seiring berkembangnya waktu pada tahun 2013 dalam pertunjukan Kesenian Babalu terkesan lebih ramai dan lebih enerjik dengan gerakan yang lumayan cepat. Penambahan alat musik berupa kendang jaipong membuat pertunjukan Kesenian Babalu lebih menarik. Selain itu kesenian Babalu juga menambah personil vokal agar semakin bersemangat dan kompak dalam meramaikan pertunjukan. Durasi yang diperlukan dalam mempertunjukan Kesenian Babalu mengalami perkembangan menjadi lebih pendek namun tetap menarik dan lumayan dinikmati Mayarakat di Kabupaten Batang

13. Dalam setiap gerakan tari dalam Kesenian Babalu apakah ada makna tersendiri disetiap geraknya? 
-Gerakan dalam Kesenian Babalu terlihat sederhana mbak namun penuh kekuatan yang ditunjukan pada ragam gerakan silat. Gerak dalam kesenian Babalu juga menggambarkan semangat para pejuang dalam merebut kembali kemerdekaan Kabupaten Batang melalui gerakangerakan keprajuritan yang penuh semangat, enerjik dan luwes. Kode peluit dalam pementasan Kesenian Babalu dimainkan oleh salah satu penari yang berperan sebagai pemimpin untuk mengawali suatu gerakan agar kompak dan saling bekerjasama dalam mengatur siasat perang.

14. Bagaimana kostum yang dikenakan oleh pemain ketika pementasan?

-Kostum yang digunakan dalam pertunjukan Kesenian Babalu berasal dari Sanggar Putra Budaya Desa Proyonanggan Kabupaten Batang ada rompi, slempang, kupluk berkucir, rapek, sabuk, celana merah, baju merah, kaoskaki dan kacamata.

15. Berapa dana yang harus dikeluarkan untuk bergabung di Sanggar Putra Budaya?

-Untuk biaya dalam pelatihan kesenian babalu yaitu 40ribu selama 1 bulan untuk 4 kali pertemuan mbak

\subsection{Pemain Kesenian Babalu di Sanggar Putra Budaya Desa Proyonanggan} Kabupaten Batang yang terdiri dari Penari dan Pemusik Kesenian Babalu

\subsubsection{Penari ( risa )}

1. Sejak kapan anda menjadi penari Kesenian Babalu 
- Sejak saya berumur 10 tahun mbak, saya bergabung di sanggar putra budaya, sekarang saya berumur 22 tahun

2. Sebelum ada pelatihan tari di Sanggar Putra Budaya apakah anda sudah bisa menari?

- Belum mbak, dengan belajar tari di sanggar putra budaya saya menjadi bisa menari

3. Apakah gerakan Kesenian Babalu yang dilakukan sulit?

- Pada awalnya saya merasa gerakan kesenian babalu sulit namun setelah hafal gerakannya terasa lebih mudah mbak, apalagi dengan adanya pelatih kesenian Babalu di Sanggar Putra Budaya yang selalu sabar mengajari saya mbak, hingga akhirnya saya dapat menguasai gerakan dalam Kesenian Babalu dan melatihkannya kepada teman-teman saya mbak

4. Apakah tujuan dan motivasi anda dalam ikut serta menjadi pemain dalam Kesenian Babalu di Kabupaten Batang?

- Saya ingin turut melestarikan kesenian babalu agar menjadi kesenian khas dari kabupaten batang yang dikenal oleh wilayah lain mbak

5. Bagaimana proses pelatihan Kesenian Babalu di Sanggar Putra Budaya Desa Proyonanggan Kabupaten Batang?

- Proses pelatihan tari di sanggar putra budaya sangat menyenangkan mbak, setiap gerakan yang dilatihkan selalu di ulang-ulang agar siswa dapat selalu mengingat dan hafal mbak.

6. Berapakali dalam satu bulan anda berlatih Kesenian Babalu di Sanggar Putra Budaya Desa Proyonanggan Kabupaten Batang? 
- 4 kali latihan mbak

\subsection{Sukiyanto sebagai pemusik Kesenian Babalu di Sanggar Putra Budaya} Desa Proyonanggan Kabupaten Batang ( 3 April 2017 )

1. Alat musik apa saja yang digunakan dalam mengiringi Kesenian Babalu?

- Alat musik yang digunakan berupa bonang, kenong, saron, demung, kentongan, rebana, kempul, dan gong. Namun terkadang juga ditambahkan keyboar, perkusi atau menggunakan kendang jaipong agar dalam pertunjukan kesenian Babalu terdengar lebih ramai mbak

2. Lagu apa saja yang digunakan dalam iringan Kesenian Babalu?

- Menggunakan lagu asli dari Batang yaitu berjudul babalu mbatang mbak dan juga menggunakan lagu tradisional ilir-ilir.

3. Seperti apa lirik lagu Babalu Mbatang yang dinyanyikan dalam iringan Kesenian Babalu?

Asalmulane Babalu Mbatang

Sing wis ono kadek jaman perjuangan

Digunaake kanggo siasat perang

Pie carane pie menange

Mbang cepokokuning cepokokuning kembang melati

Mari kita nikmati kesenian Babalu ini 
4. Seperti apa lirik lagu Ilir-ilir yang dinyanyikan dalam iringan Kesenian Babalu?

Lir ilir lir ilir

Tandure wus sumilir

Tak ijo royo-royo

Tak sengguh temanten anyar

Cah angon, cah angon

Penekno blimbing kui

Lunyu-lunyu penekno

Kanggo mbasuh dodotiro

Dodotiro dodotiro

Kumintir bedhah ing pinggir

Dondomono, Jlumatono

Kanggo sebo mengko sore

Mumpung padhang rembulan

Mumpung jembar kalangan

Yo surako surak iyo

5. Apa arti lirik lagu Babalu Mbatang dalam iringan Kesenian Babalu? 
- Lirik lagu dalam lagu Babalu Mbatang mempunyai arti yang ada kaitannya dengan sejarah Kesenian Babalu yaitu menunjukan bahwa kesenian Babalu sudah hidup sejak jaman perjuangan dan digunakan sebagai siasat perang. Para pejuang mencari cara agar dapat mengalahkan penjajah yaitu dengan menggunakan kode/peluit dan suatu tarian untuk mengelabuhi penjajah dan disuguhi minuman, hingga akhirnya para pejuang berhasil melawan penjajah yang telah lengah

\section{Lampiran 3. SK Penetapan Dosen Pembimbing}




\section{雨 \\ UNNES \\ KEPUTUSAN \\ DEKAN FAKULTAS BAHASA DAN SEN \\ UNIVERSITAS NEGERI SEMARANG \\ Nomor: 1889/FBS/2016 \\ PENETAPAN DOSEN PEMBIMBING SKRIPS \\ MEIR SEMESTER \\ TAHUN AKADEMIK 2016/2017}

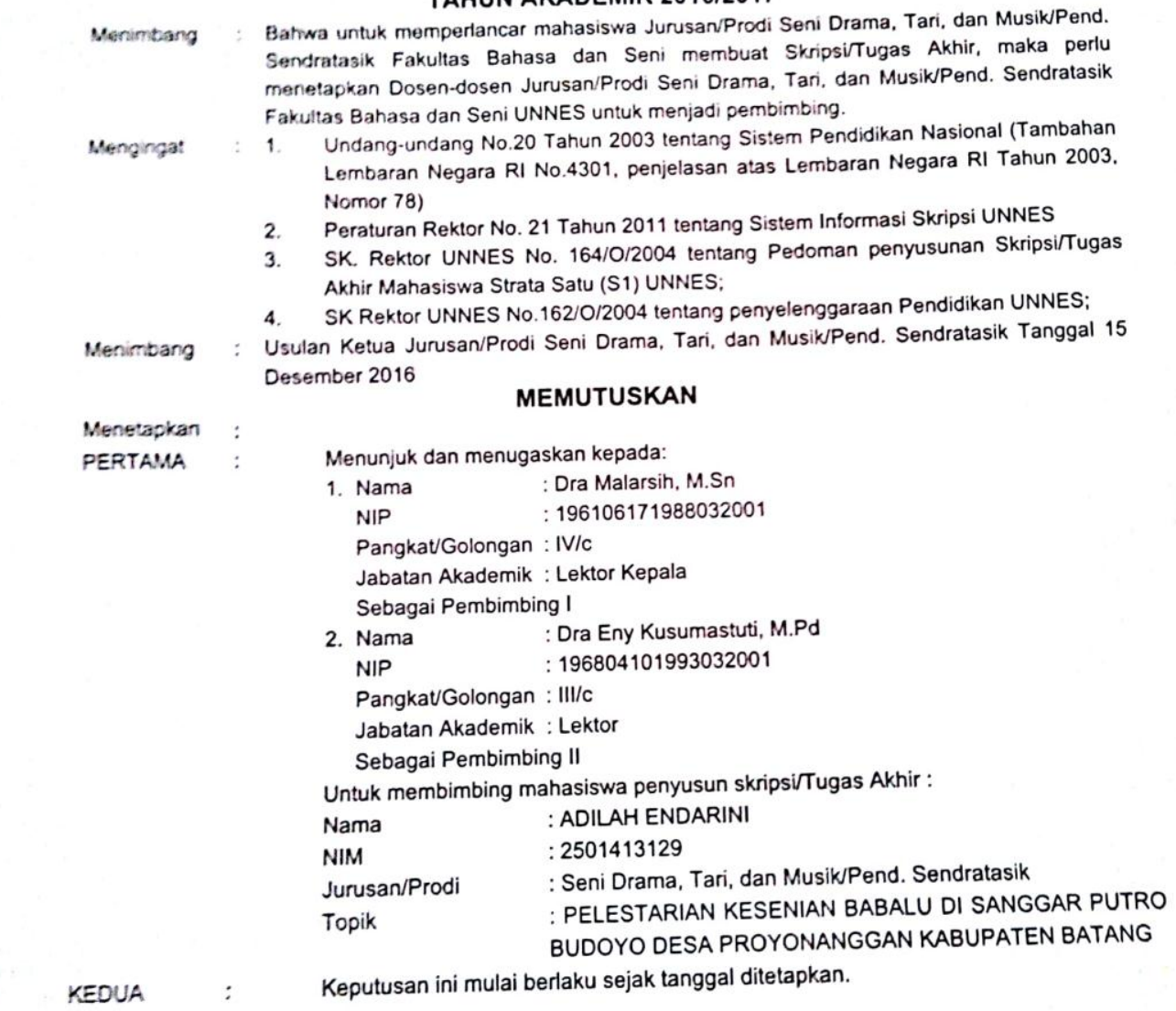

DITETAPKAN DI : SEMARANG

PADA TANGGAL : 19 Desember 2016

Tembusan

1. Pembantu Dekan Bidang Akademik

2. Ketua Jurusan

3. Petinggal

\section{เurmin!}

25016:312

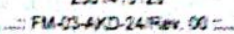

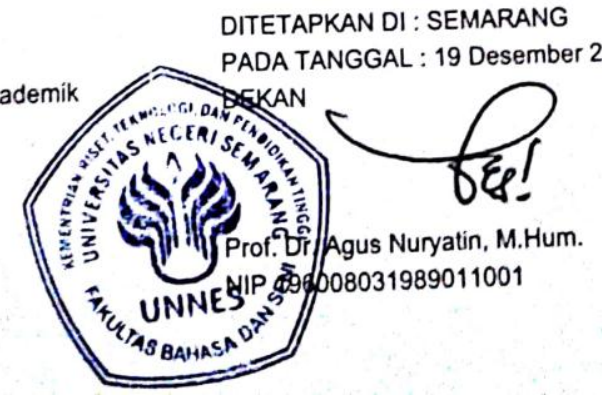

Endarini, tanggal 2 April 2017) 
